\title{
Do fermented dairy products and calcium protect against colorectal cancer? : contributions from epidemiology
}

Citation for published version (APA):

Kampman, E. (1994). Do fermented dairy products and calcium protect against colorectal cancer? : contributions from epidemiology. [Doctoral Thesis, Maastricht University, Maastricht University]. Maastricht Rijksuniversiteit Limburg. https://doi.org/10.26481/dis.19940930ek

Document status and date:

Published: 01/01/1994

DOI:

10.26481/dis.19940930ek

Document Version:

Publisher's PDF, also known as Version of record

\section{Please check the document version of this publication:}

- A submitted manuscript is the version of the article upon submission and before peer-review. There can be important differences between the submitted version and the official published version of record. People interested in the research are advised to contact the author for the final version of the publication, or visit the DOI to the publisher's website.

- The final author version and the galley proof are versions of the publication after peer review.

- The final published version features the final layout of the paper including the volume, issue and page numbers.

Link to publication

\footnotetext{
General rights rights.

- You may freely distribute the URL identifying the publication in the public portal. please follow below link for the End User Agreement:

www.umlib.nl/taverne-license

Take down policy

If you believe that this document breaches copyright please contact us at:

repository@maastrichtuniversity.nl

providing details and we will investigate your claim.
}

Copyright and moral rights for the publications made accessible in the public portal are retained by the authors and/or other copyright owners and it is a condition of accessing publications that users recognise and abide by the legal requirements associated with these

- Users may download and print one copy of any publication from the public portal for the purpose of private study or research.

- You may not further distribute the material or use it for any profit-making activity or commercial gain

If the publication is distributed under the terms of Article $25 \mathrm{fa}$ of the Dutch Copyright Act, indicated by the "Taverne" license above, 


\title{
Do fermented dairy products and calcium protect against colorectal cancer ?
}

\author{
contributions from epidemiology
}

PROEFSCHRIFT

ter verkrijging van de graad van doctor

aan de Rijksuniversiteit te Maastricht,

op gezag van de Rector Magnificus, Prof. Dr. H. Philipsen, volgens het besluit van het College van Dekanen,

in het openbaar te verdedigen

op vrijdag 30 september 1994

om 14.00 uur

door

Ellen Kampman 
Promotores:

Co-promotor:

Beoordelingscommissie: Prof.dr. W.H.M. Saris (voorzitter)

Prof.dr. P.G. Knipschild

Prof.dr. R.W. Stockbrügger

Prof.dr. G.H. Blijham (Universiteit van Utrecht)

Prof.dr. W.C. Willett (Harvard School of Public Health)

\section{CIP-GEGEVENS KONINKLIJKE BIBLIOTHEEK, DEN HAAG}

Kampman, Ellen

Do fermented dairy products and calcium protect against colorectal cancer?

Contributions from epidemiology/ Ellen Kampman. - [S.1 : s.n.] (Wageningen:

Ponsen \& Looijen). $-[1]$.

Thesis Maastricht. - With ref. - With summary in Dutch.

ISBN 90-9007445-7

Subject headings: fermented dairy products / colorectal cancer / epidemiology

$\begin{array}{ll}\text { Lay-out: } & \text { Hanny Leezer } \\ \text { Omslag: } & \text { Franz Marc: The yellow cow. Oil on canvas, } 1911 \\ & \text { Solomon R. Guggenheim Museum, New York. } \\ \text { Druk: } & \text { Grafisch bedrijf Ponsen \& Looijen BV Wageningen }\end{array}$

The studies in this thesis were mainly carried out at the Department of Epidemiology, TNO Nutrition and Food Research in Zeist, The Netherlands. They were financially supported by the Dutch Dairy Foundation on Nutrition and Health, the Netherlands Digestive Diseases Foundation and the Dutch Cancer Society. The studies described in Chapter 3 were conducted at the Harvard School of Public Health in Boston, US, and were supported by grants from the National Institutes of Health, the American Cancer Society, the National Dairy Promotional Research Board administered in cooperation with the National Dairy Council, The Netherlands Digestive Diseases Foundation, The Netherlands Organization for Scientific Research, and the Dutch Dairy Foundation on Nutrition and Health.

Financial support for the publication of this thesis was provided by the Netherlands Digestive Diseases Foundation. 
'Here is Edward Bear, coming downstairs now, bump, bump, bump, on the back of his head, behind Christopher Robin. It is, as far as he knows, the only way of coming downstairs, but sometimes he feels that there really is another way, if only he could stop bumping for a moment and think of it'

(from Winnie-the-Pooh, A.A. Milne) 



\section{Contents}

1 Introduction 1

2 Aetiology of colorectal cancer $\quad 7$

Colorectal adenomatous polyps in the US Nurses Health Study and the US Health Professionals Follow-Up Study

3 Calcium, vitamin D, dairy foods and the occurrence of colorectal adenomas among men and women in two prospective studies

\section{Colon cancer in the Netherlands Case-Control Study}

4 Design, conduct and analysis of the case-control study

5 Fermented dairy products, dietary calcium and colon cancer 85

6 Reproductive and hormonal factors in male and female colon cancer 103

7 Vegetable and animal products as determinants of colon cancer risk 117 in Dutch men and women

Colorectal cancer in the Netherlands Cohort Study on diet and cancer

8 Fermented dairy products, calcium and colorectal cancer in the Netherlands Cohort Study

9 General discussion

Summary

Samenvatting

Dankwoord/Acknowledgements

Acknowledgements Hospitals

About the author 


\section{Chapter 1}

Introduction 



\section{Introduction}

Colorectal cancer contributes considerably to the incidence of cancer in the Netherlands, like in most westernized countries. Each year a malignant tumor of the colon or rectum is newly diagnosed in about 7,000 Dutch men and women.' Colorectal cancer is the third most common cancer among men, after cancer of the lung and the prostate, and the second most common among women, behind breast cancer.' Although new methods of surgery, chemotherapy and radiotherapy are being developed and applied, mortality rates of colorectal cancer remain relatively high. New developments in treatment are not expected to markedly increase survival rates in the near future, which makes prevention of this type of cancer even more important.

A role of dietary factors in colorectal carcinogenesis seems biologically plausible and is also widely recognized. Changes in dietary patterns may provide important clues in colorectal cancer prevention. Both experimental research and analytical epidemiology provide possibilities to unravel the various aspects of a westernized diet involved in the aetiology of colorectal cancer. The results of these studies, however, have not yielded clues for preventive measures that can be implemented easily in the population at large.

Like a diet rich in vegetables and fruits, a high consumption of fermented dairy products, such as yogurt, buttermilk and cheese, might decrease colorectal cancer risk. Fermentation of dairy products with lactic acid bacteria is an ancient method of preservation, and for centuries several of these bacteria species have been believed to contribute to the prevention and treatment of gastro-intestinal disturbances. Already in 1908, Eli Metchnikoff developed a theory that lactic acid bacteria in the digestive tract could prolong life. ${ }^{2}$ More recently, a protective effect on tumor development has been suggested for these specific dairy products. ${ }^{3.4}$ This hypothesis mainly derives from experimental research, as epidemiological studies considering the effect of fermented dairy products on cancer are scanty. In addition to their content of lactic acid bacteria, fermented dairy products are an important source of calcium. Experimental and epidemiological studies suggest a protective effect of calcium in colorectal carcinogenesis. However, the results of epidemiological studies are still controversial and a higher intake of this nutrient is not generally recommended yet. 
Chapter 2 of this thesis provides an overview of current knowledge on the aetiology of colorectal cancer and summarizes results of experimental and epidemiological studies on the associations between consumption of fermented dairy products, intake of calcium and colorectal cancer risk which have been published before and during the studies included in this thesis.

In most epidemiological studies, the consumption of dairy products and calcium is just one of the many dietary factors studied. The specific aim of the research described in this thesis was to study whether the consumption of fermented dairy products and the intake of calcium is inversely associated with the risk of colorectal cancer and thus might become tools in its prevention. The thesis includes four epidemiological studies described in Chapters 3 through 8, which differ with respect to disease end-point, study design, methods of exposure assessment and study population.

Chapter 3 describes results of two ongoing prospective studies at the Harvard School of Public Health in Boston, US: the Nurses' Health Study and the Health Professionals Follow-up Study. The analyses focus on the association with colorectal adenomatous polyps, which are considered to be precursors of colorectal cancer.

Chapters 4 through 7 describe the results of a case-control study on colon cancer conducted in the Netherlands between 1990 and 1993. This study was intentionally conducted in the Netherlands, since the consumption of fermented dairy products is traditionally integrated in the Dutch food pattern. This case-control study is one of the first population-based case-control studies in the Netherlands in which the Cancer Registry was successfully used for case recruitment; furthermore, an alternative procedure of control recruitment was applied. These aspects of design and conduct are discussed in detail in Chapter 4. In Chapter 5 the main hypothesis is tested, while Chapters 6 and 7 deal with other life-style and dietary factors which were additionally explored.

Finally, Chapter 8 describes the association between fermented dairy products, calcium and colorectal cancer as studied prospectively in the ongoing Netherlands Cohort Study on diet and cancer.

Chapter 9 integrates the results of the four studies and reviews the strengths and limitations of the studies. Moreover, results are discussed in the context of previously published epidemiological and experimental studies.

Chapters 3,5, 6, 7 and 8 are included in this thesis in the form in which they have been published, accepted or submitted for publication in international journals. 


\section{References}

1. Netherlands Cancer Registry. Incidence of cancer in the Netherlands. Second report of the Netherlands Cancer Registry, 1990.

2. Metchnikoff E. The prolongation of life. Optimistic studies. G.P. Putman and Sons, New York 1908.

3. Hitchins $\mathrm{AD}$ and McDonough FE. Prophylactic and therapeutic aspects of fermented milk. Am J Clin Nutr 1989;49:675-684.

4. Fernandes CF and Shahani KM. Anticarcinogenic and immunological properties of dietary lactobacilli. J Food Prot 1990:53:704-710. 



\section{Chapter 2}

Aetiology of colorectal cancer 


\section{Contents}

\section{Current concepts}

Proliferation, adenoma and carcinoma formation

Changes on the molecular level

The role of diet and life-style

Hormonal influences

Fermented dairy products and calcium: a hypothesis

Ecological studies

Analytical epidemiological studies

Experimental studies 


\section{Current concepts}

\section{Proliferation, adenoma and carcinoma formation}

The classical view of carcinogenesis included two stages: initiation, which involved mutation of the DNA, and promotion, in which expansion of initiated cells occurred. Nowadays, carcinogenesis is considered to be a multistage process, involving 5 or more different changes. ${ }^{1}$ In the past decades, several of the different stages in colorectal cancer development are more precisely identified. It is believed that tumorigenesis of colorectal adenocarcinomas proceeds through mucosal cell hyperproliferation to adenoma formation, growth, and malignant transformation. ${ }^{2}$ Studies on a inherited greatly predisposing condition for colon cancer, Familial Adenomatous Polyposis (FAP), confirm this hypothesized pathway. In FAP patients as well as disease free relatives, an increased thymidine labelling index, expansion of the proliferative zone, surface labelling and acceleration of migration rate in the flat mucosa between existing polyps and tumors as well as in the mucosa prior to polyp formation have been identified. ${ }^{3.4}$ Increased colonic epithelial cell proliferation has also been observed in sporadic colorectal cancer cases.

It has been observed that a high proportion of large adenomas cuntain focal areas of malignancy, and a high proportion of early colorectal tumors contain remnants of adenomatous tissue. ${ }^{5}$ It has been suggested that all colorectal carcinomas have a precursor adenoma stage, although most adenomas do not progress to malignancy and remain benign. ${ }^{5}$ Adenomatous polyps antedate the clinical diagnosis of colorectal cancer by an average of approximately ten years. ${ }^{5}$

Whereas adenomas are evenly distributed along the large intestine, ${ }^{2}$ carcinomas are more likely to develop in the sigmoid colon or rectum. Large adenomas are also more common in the sigmoid colon, suggesting that factors that cause the initial formation of an adenoma differ from those that cause its subsequent growth. ${ }^{2}$

The risk of developing an adenoma might depend on both genetic and environmental factors, with the former determining which members of a uniformly exposed population are at greatest risk of developing the disease and the latter determining the proportion of the high-risk component of the population that actually does so. ${ }^{5}$

\section{Changes on the molecular level}

Vogelstein and colleagues have provided extensive evidence that there is an accumulating series of chromosomal and genetic alterations that accompany the transition from the normal colonic mucosa to carcinoma." According to this model (Figure 2.1), the accumulation of at least four or five genetic changes are required 
to produce a malignant tumor, their order not being of critical relevance. ${ }^{6}$ Several different genetic alterations which occur during colorectal tumorigenesis have been identified, involving activation of oncogenes coupled with the inactivation of tumor suppressor genes.

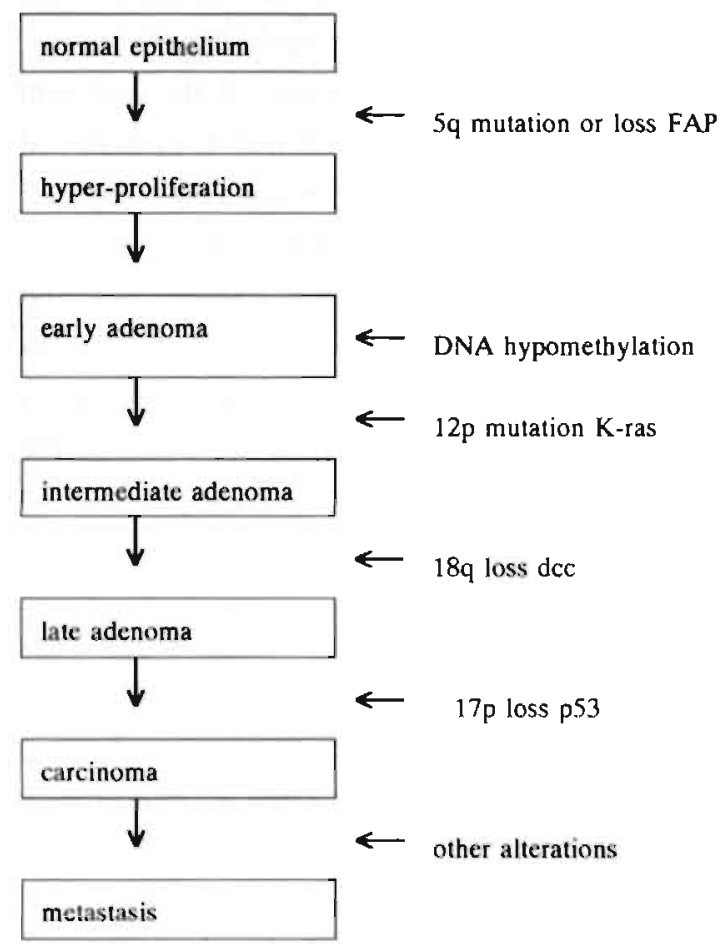

Figure 2.1 Hypothesized genetic model for colorectal tumorigenesis according to Fearon and Vogelstein; the accumulation of changes rather than their order is considered relevant in this model for determining the tumor's biological properties. ${ }^{6}$

Although the order of genetic changes is not critical, a given order might be more frequently observed. One of the earliest genetic changes accompanying tumor progression is a significant loss of methyl groups in DNA. ${ }^{7}$ The role of this hypomethylation is still unclear. It has been suggested that folate deficiency induces hypomethylation. ${ }^{8.9}$

Mutation of the ras oncogene was found in less than $10 \%$ of early-stage adenomas and in approximately $50 \%$ of intermediate-stage adenomas, late-stage adenomas and colon carcinomas. ${ }^{10}$ Three different ras-genes have been isolated: Haras, Ki-ras and $\mathrm{N}$-ras. Ki-ras mutations are most common. " The Ki-ras gene encodes for a G-protein ( $\mathrm{p} 21$ ) which may be involved in signal transduction. 
Mutations in this gene may lead to uncontrolled cell growth. ${ }^{11}$ Ki-ras mutations can be induced by methylating carcinogens. ${ }^{11}$

Allelic deletions were discovered in chromosomes 5, 17 and 18, which might harbour tumor-suppressor genes. Deletions on the short arm of chromosome 17 (17p) are common and occur in more than $75 \%$ of colorectal adenomas. These deletions appear to be relatively late events and are associated with the transition from the benign adenoma to the malignant carcinoma. ${ }^{12}$ The allelic loss on chromosome 17 has been shown to be the p53 gene, which codes for a phosphoprotein involved in the control of cell proliferation. ${ }^{1.3}$ It is speculated that a mutated p53 gene in a colorectal carcinoma can provide selective growth advantage by promoting tumor progression even in the presence of a normal p53 allele. ${ }^{14}$ P53 mutations are also common in other cancers, as breast, lung and stomach cancer. ${ }^{15}$ Exogenous and endogenous mutagens influence the type and site of the p53 gene base substitutions. ${ }^{16}$

Allelic losses on chromosome 18 are also common and occur in less than $10 \%$ of small and intermediate stage adenomas, ${ }^{14} 45 \%$ of large adenomas and in approximately $75 \%$ of colorectal carcinomas, which suggest that these events occur before p53 alterations. The deletion site (dcc=deleted in colorectal carcinomas) on chromosome $18 \mathrm{q}$ has been identified as a gene coding for a cell-adhesion molecule, mediating cell growth and differentiation. ${ }^{17}$

Allelic deletion in chromosome $5 q$ has been found in almost $40 \%$ of colorectal carcinomas and sporadic adenomas studied. ${ }^{18}$ The tumor suppressor gene (mcc $=$ mutated in colorectal carcinomas) is believed to be connected with G-protein activation, which is important in transducing signals in the cell. Additional studies are needed to elucidate the relationship between mcc gene mutations and sporadic colorectal cancers and to determine whether mcc is mutated in familial adenomatous polyposis coli families. ${ }^{14}$

The above is a reflection of current insight. The rapid developments in this area require regular updating.

\section{The role of diet and life-style}

Environmental factors are suggested to be the driving forces behind the transformation of the normal colonic mucosa to cancer, among these, diet and lifestyle are considered to be highly important. ${ }^{19}$ These factors influence the content of the colonic lumen, the enzymatic activity of the colonic flora and consequently the exposure of the epithelial cells to carcinogenic or promoting substances. ${ }^{2 n} \cdots$ Several nutritive and non-nutritive components of our diet might be involved. ${ }^{23,24}$

One of the relatively old, well-established hypotheses suggests an elevated risk as a consequence of our westernized high fat, low fiber diet..$^{23,24}$ 
Biological and -more recently- molecular explanations have been proposed. The 'physiological' explanation for this elevated risk is the bile acid/volatile fatty acid hypothesis. Dietary fat increases the bile acid and fatty acid excretion in the colonic lumen. ${ }^{25}$ The microbial flora hydrolyses the polar glyco and tauro conjugate bile acids to form secondary bile acids in the faeces. ${ }^{5}$ Secondary bile acids in their ionized form and free fatty acids may damage the colonic epithelium, stimulating cell proliferation. ${ }^{26-29}$ Two bacterial enzymes have been proposed to be important in the colonic bile-acid metabolism: 7-dehydroxylase and 4-5 nuclear dehydrogenase, which are more frequently present in populations with a high risk of colorectal cancer. ${ }^{311}$ The activity of these enzymes is not favoured by acidic conditions. ${ }^{30}$

Moreover, it has been suggested that the colonic flora converts free fatty acids in diacylglycerol (DAG) which is an activator of protein kinase $C$, inducing cell replication signals. ${ }^{31}$

Dietary fiber binds bile acids and free fatty acids, increases stool bulk, and can be fermented to volatile fatty acids. These may be directly anti-carcinogenic ${ }^{32}$ and by lowering $\mathrm{pH}$ may reduce the conversion of primary to secondary bile acids as well. $^{33}$

In order to explain the role of a high fat/low fiber diet on the molecular level, these dietary factors have been viewed as indicators for carcinogenic and anticarcinogenic substances. Vegetables and fruits are not only important sources of fiber, but also contain vitamin $\mathrm{C}$, carotenoids, phenols, flavonoids and indoles, with a variety of anti-carcinogenic properties. ${ }^{34,35}$ Vegetable consumption has been consistently shown to be inversely associated with colon cancer risk in epidemiological studies, though inverse associations with fruit consumption have been less frequently observed. ${ }^{35.36}$ Howe and colleagues completed a meta-analyses of 13 case-control studies and concluded that a higher overall fiber intake decreases colon cancer risk. ${ }^{37} \mathrm{~A}$ high fat diet might be a source of arylamines from meat proteins $^{38}$ and cancer promoters resulting from high temperature cooking. ${ }^{39}$ In ecological studies both a high fat and a high meat diet have been correlated with colorectal cancer risk. ${ }^{23}$ As reviewed by Potter et al., ${ }^{40}$ analytical epidemiological studies on fat, protein and meat consumption show, almost consistently, a positive association with risk of colorectal cancer.

In addition to this 'established' theory, other factors which have been suggested to exert an effect on colorectal cancer risk are physical activity, alcohol consumption, parity (see hormonal factors), use of nonsteriodal anti-inflammatory drugs, cholecystectomy, caffeine and smoking.

Physical activity stimulates colon peristalsis and decreases random, nonpropulsive segmentation activity. ${ }^{41}$ The resulting shortened stool transit time and decrease in segmentation-induced mixing may give putative fecal carcinogens less contact with 
the colonic mucosa. In epidemiologic studies, physical activity has been consistently associated with an increased risk of colon cancer. ${ }^{40}$ Total energy intake is often considered to be an acceptable proxy for physical activity. In most prospective studies, no association with total energy has been found. In most case-control studies, an elevated risk has been observed with increasing energy intake, but this might be attributed to a general overreporting of the cases.

The mechanism by which alcohol entails an increased risk for colorectal cancer is not clear. One hypothesis involves its effects on lipid secretion and metabolism. Moderate alcohol intake decreases cholesterol saturation of bile by increasing bile acid concentration. ${ }^{42}$ Longnecker and colleagues conducted a meta-analysis on alcohol and colorectal cancer including 27 epidemiologic studies, and concluded that because the magnitude of the association between alcohol and risk of colorectal cancer was small, the findings regarding a causal role of alcohol were inconclusive. $^{43}$

Non-steroidal anti-inflammatory drugs inhibit the synthesis of prostaglandins which might play a role in cell proliferation, neoplasia and immune response. ${ }^{\text {t4 }}$

Cholecysectomy might increase colon cancer risk by the alteration of the bile acid secretion that follows after removal. A meta-analyses on 33 case-control and 6 cohort studies conducted by Giovannucci and colleagues, showed a significant positive association between cholecystectomy and risk of colorectal cancer from the case-control data, while the results from cohort studies were generally null. Time since cholecystectomy appeared to be important. Although risk varied by study design and in most studied time since cholecystectomy was not reported, the authors conclude that some characteristics of bile-acid metabolism increases the risk of cancer of the proximal colon. ${ }^{45}$

Caffeine might increase serumcholesterol. ${ }^{46}$ If the mechanism leading to higher cholesterol levels involves a reduction in the excretion of bile acids, coffee consumption might reduce the risk of colorectal cancer. However, in his review of the epidemiologic literature Rosenberg concludes that although some studies suggest an inverse association, 'the data are not compelling and a biological mechanism is not established'. ${ }^{47}$

The physiological mechanism by which smoking might increase colon cancer risk is unclear. One possibility might be via the production and swallowing of compounds such as arylamines. Although several epidemiological studies suggest an association between smoking and colorectal adenoma risk, only recently Giovannucci and colleagues reported a significant positive association with colorectal cancer in the Nurses Health Study and the Health Professionals Followup study. ${ }^{48.4 \%}$ They point to the fact that the induction period between the start of smoking and the diagnosis of cancer is important in this respect and might be at least 35 years. 


\section{Hormonal influences}

Although colon cancer is essentially the only cancer that occurs with approximately equal frequency in men and women, the rates tend to show an excess among women before the age of 50 years and an excess among men after that age, as reviewed by Potter and colleagues. ${ }^{40}$ Subsite risk has also been shown to vary by sex: women have higher rates of right-sided carcinoma. ${ }^{40}$ Possibly, there are sex differences in etiology, which may be explained by environmental and or hormonal factors. ${ }^{50}$ In 1980 , McMichael and Potter proposed that higher parity, early age at first birth, and use of oral contraceptives would each be associated with a reduced risk of colon cancer as a result of changes in lipids and bile acids that occur with changes in the hormonal milieu. ${ }^{51}$ Sex hormones might also moderate cell proliferation and differentiation other than by intraluminal sterol metabolism. ${ }^{50}$

Most case-control studies confirm an inverse association between parity and colorectal cancer risk, while the studies of other reproductive factors such as age at first birth, age at menarche and age at menopause are more limited and less persuasive..$^{50}$ The review by Potter et al. indicated that the results of prospective studies do not suggest an association with parity and age at first birth. ${ }^{40}$ The authors suggest that it is only in older women that higher parity is associated with reduced risk, which is comparable to the suggested association between parity and breast cancer risk. ${ }^{40}$

Both case-control and cohort studies do not consistently support a substantial reduction of colon cancer risk with the use of exogeneous hormones. ${ }^{40}$

Another observation which might explain differences in colorectal cancer risk between men and women is that gender-related differences in gut metabolism exists. Men and women show, under controlled experimental conditions, differences in large bowel function (stool bulk, transit time, volatile fatty acid production) and bile acid excretion. ${ }^{52}$

\section{Fermented dairy products and calcium: a hypothesis}

Besides the 'established' risk factors, relatively new hypotheses concern the potential protective role of fermented dairy products ${ }^{53}$ (e.g. yogurt, buttermilk, cheese) and calcium ${ }^{54}$ in colorectal carcinogenesis.

\section{Ecological studies}

Associations between colorectal cancer incidence or mortality and national consumption of milk or milk products have been reported by several investigators. Alder and McKeown-Eyssen reviewed these ecological data ${ }^{55}$ and concluded that 6 
out of 12 studies conducted before 1988 observed a positive association, while the other half reported a negative association. All studies reporting a negative association controlled for dietary fat intake in the analysis. Their own ecological study among 38 countries, using food disappearance data ${ }^{56}$ suggests an inverse association between the availability of total dairy products and colon cancer mortality, adjusting for animal fat and cereal fiber intake $(r=-0,36, p<0.05)$. The inverse relationship with dairy product intake in the 38-countries study was mainly attributable to two of the countries included, i.e. Finland and Iceland. ${ }^{57}$ In Finland, the intake of dairy products, non-fermented as well as with Lactobacilli fermented milk products is highest in the world. In a cross-sectional study in Scandinavia comparing various risk factors in men from a high risk (Copenhagen) and low risk area (rural Finland), representing a threefold difference in colon cancer incidence, the intake of milk and dietary fiber was higher in low risk areas, whereas no difference in saturated fat intake was observed. ${ }^{58}$ A higher number of faecal Lactobacilli were counted among the low-risk Fins as compared to the high-risk Danish men. ${ }^{58}$ However, in an extension of this study including two additional study areas with intermediate incidences (rural Denmark and Helsinki), the association with milk and milk product intake did not remain significant. ${ }^{59}$ As the intake of milk products in Denmark is relatively high as well, the difference in intake between the Finnish and Danish may not be high enough to observe an association. In a study by Benno et al.$^{60}$ higher numbers of fecal lactobacilli were found in Japanese at low risk of colon cancer compared to Canadians at high risk.

As previous ecological studies did not specifically address fermented dairy products, we investigated the correlation between per capita consumption of fermented milk and the incidence of colon cancer among 16 countries. In these analyses, fermented milk intake per capita in $1981^{61}$ was not correlated with colon cancer incidence ${ }^{62}$ perse, but after adjusting for $\%$ energy from fat a negative correlation $(\mathrm{r}=-0.49, \mathrm{p}=0.05)$ was demonstrated (Figure 2.2). When Finland was excluded from these analyses, the correlation did not remain significant.

Dairy products contribute significantly to daily calcium intake. In the Netherlands $70 \%$ of calcium intake is from dairy sources. It has been suggested from ecological as well as experimental studies that a protective effect of dairy products in general may be attributed to the calcium content of dairy products. ${ }^{54}$ In the US the intake of calcium is lowest in the north-eastern states where colon cancer mortality is highest. ${ }^{63}$ However, in the 38 -countries study, no association with calcium was observed. $^{55}$

In general, one should be careful interpreting results from ecological studies as the assessment of intake and incidence data is hardly comparable between countries. Furthermore, since data necessary to control for confounding at an individual level 
are not available, results from these international correlations require confirmation by individual based analytical epidemiology. ${ }^{64}$

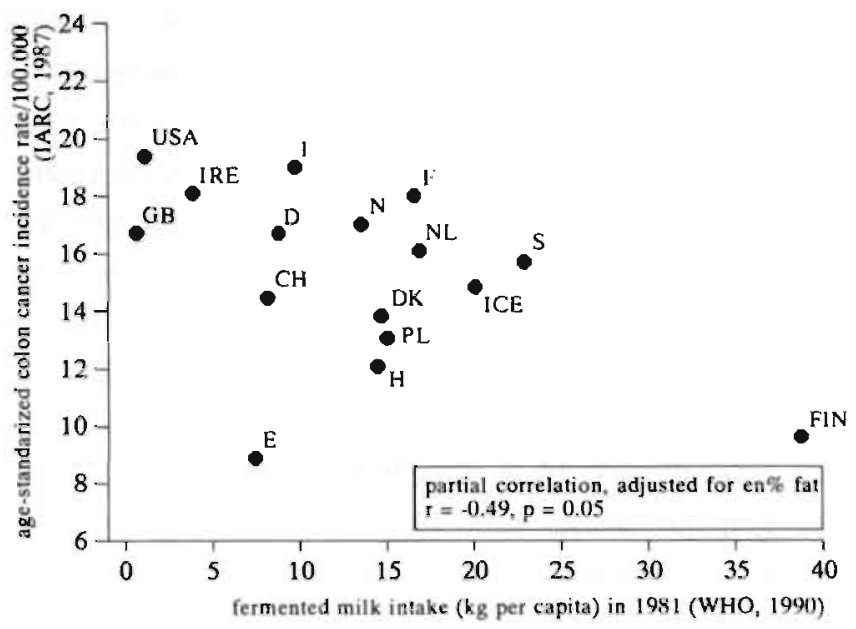

Figure 2.2 Per capita consumption of fermented milk consumption and colon cancer incidence.

\section{Analytical epidemiological studies}

In contrast to ecological studies, case-control and cohort studies provide the possibility to adjust for potential confounding variables.

As we started our investigation on the association of fermented dairy products, calcium and colorectal cancer in 1990, results from other comparable studies conducted before and in or after 1990) will be discussed in chronological order.

Table 2.1a shows the main characteristics and results of 13 case-control studies conducted before 1990, which addressed the relationship between the consumption of (fermented) dairy products, calcium intake and colorectal cancer or polyp risk. Two retrospective studies addressed the intake of fermented milk (yogurt and buttermilk). ${ }^{65,(x)}$ An inverse association with fermented milk and colon cancer was observed in a American study conducted by Young and Wolf $(\mathrm{OR}=0.65,95 \%$ $\mathrm{Cl}=0.41-1.01){ }^{a s}$ while a Japanese study observed a positive non-significant association with yogurt ( $O R=1.52$ (ns)). ${ }^{\text {(t) }}$ In the American study an inverse assicociation with cheese consumption was found $(\mathrm{OR}=0.72,95 \% \mathrm{CI}=0.51-1.05)$, ${ }^{\text {, }}$ which was also not confirmed in the Japanese study $(\mathrm{OR}=1.36(\mathrm{~ns}))^{6{ }^{66}}$ A French case-control study mentioned a non-significant inverse association with cheese consumption ( $\mathrm{OR}=0.9$ ) for colorectal cancer, ${ }^{67}$ and a non-significant positive association $(\mathrm{OR}=1.2)$ for colorectal polyps. ${ }^{68}$ In a Belgium study an $\mathrm{OR}$ of 1.0 was 
found for cheese consumption. ${ }^{69}$

For total dairy products, Slattery and colleagues ${ }^{70}$ observed a significant negative association in Utah, while an Australian ${ }^{71}$ and an American study ${ }^{72}$ observed weak non-significant negative associations and a study in Greece describes a weak nonsignificant positive association. ${ }^{73}$

Approximately, one third of the case-control studies included in Table 2.1a support an inverse association with milk or calcium. In the study conducted by Slattery et al. a significant negative association with colon cancer was observed. ${ }^{70}$ Kune and colleagues observed a non-significant decreased risk with high milk, high calcium consumption after adjustment for many confounding variables. ${ }^{71}$ Nonsignificant inverse associations were observed in three other studies for colon cancer ${ }^{67.74,75}$ and in one other for rectal cancer. ${ }^{66}$ Miller et al. ${ }^{76}$ and Manousos et al. ${ }^{73}$ both observed slightly elevated risk associated with high milk consumption. After adjustment for fat intake, this association was not longer significant. A nonsignificant positive association with calcium was also observed in the Belgian study by Tuyns et al. ${ }^{77}$

Prospective cohort studies conducted before 1990) were not conclusive either (Table 2.2a). One of the four studies conducted addressed the consumption of cheese, which intake was significantly positively associated with colon cancer death in men, and non-significantly inversely associated with colon cancer death in women. ${ }^{78}$ In the same study, milk consumption was inversely associated with colon cancer death in men. ${ }^{78}$ However the number of deaths in the reference category was too small to draw firm conclusions.

Calcium was found to be significantly inverse associated in one of these four studies. In this study by Garland and colleagues, ${ }^{79}$ two dietary histories were obtained one year apart from a cohort of approximately 2,000 men who were followed for a period of 19 years. The risk of colorectal cancer was found to be about three times higher in men who consumed the lowest levels of calcium compared to those with the highest consumption and a dose-response relationship was observed. In contrast, two other prospective studies by Heilbrun et al.$^{80}$ and $\mathrm{Wu}$ et al. $^{81}$ did observe no association and a non-significant inverse association respectively. In both studies no association with fat intake was observed. None of the prospective results addressed colorectal polyps.

After 1989, while we were conducting our study, another 12 case-control and 4 prospective studies reported their results on dairy products, calcium and colorectal cancer. One large case-control study by Peters and colleagues on colon cancer addressed the consumption of yogurt: an odds ratio of 0.8 per 10 grams of yogurt was observed assuming a log-lineair dose-response, and adjusted for dietary calcium. ${ }^{82}$ 
Table 2.1a. Dairy products, calcium, colorectal polyps and colorectal cancer: 13 case-control studies 1975-1989.

\begin{tabular}{|c|c|c|c|c|c|c|c|c|}
\hline $\begin{array}{l}\text { First author, } \\
\text { year [ref] }\end{array}$ & Population & $\begin{array}{l}\text { No. of cases/ } \\
\text { endpoint }\end{array}$ & Controls/source & $\begin{array}{l}\text { Dietary } \\
\text { method }\end{array}$ & $\begin{array}{l}\text { Risk estimates } \\
\text { lowest intake }\end{array}$ & (OR) highest vs & $\begin{array}{l}\text { Calcium intake (or } \\
\text { contrast) among } \\
\text { controls (mg/day) }\end{array}$ & Adjusted for \\
\hline $\begin{array}{l}\text { Miller, } 1983 \\
{[76]}\end{array}$ & Canada & $\begin{array}{l}542 \text { colorectal } \\
\text { cancer }\end{array}$ & $\begin{array}{l}535 \text { hospital and } \\
\text { neighbourhood }\end{array}$ & diet hist & $\begin{array}{l}\mathrm{OR}_{\mathrm{CM}} \\
\mathrm{OR}_{\mathrm{CF}} \\
\mathrm{OR}_{\mathrm{R}, \mathrm{M}} \\
\mathrm{OR}_{\mathrm{R}, \mathrm{F}}\end{array}$ & $\begin{array}{l}=1.2(\mathrm{~ns}) \\
=1.3(\mathrm{~ns}) \\
=1.1(\mathrm{~ns}) \\
=1.2(\mathrm{~ns})\end{array}$ & $\mathrm{nm}$ & age, saturated fat \\
\hline $\begin{array}{l}\text { Manousos, } \\
198.3[7.3]\end{array}$ & Greece & $\begin{array}{l}100 \text { colorectal } \\
\text { cancer }\end{array}$ & 100 hospital & $\begin{array}{l}\text { diet hist } \\
(j=80)\end{array}$ & $\begin{array}{l}\text { milk and milk } p \\
\text { OR }\end{array}$ & $\begin{array}{l}\text { products: } \\
=1.2(0.6,2.4)\end{array}$ & $\mathrm{nm}$ & - \\
\hline $\begin{array}{l}\text { PickJe, } 1984 \\
{[72]}\end{array}$ & $\begin{array}{l}\text { US, } \\
\text { Nehriska }\end{array}$ & $\begin{array}{l}86 \text { colorectal } \\
\text { cancer }\end{array}$ & 176 hospital & $\begin{array}{l}\text { diet hist } \\
(i=57)\end{array}$ & $\begin{array}{l}\text { dairy products: } \\
\qquad \mathrm{OR}_{\mathrm{c}} \\
\mathrm{OR}_{\mathrm{R}}\end{array}$ & $\begin{array}{l}=0.74(\mathrm{~ns}) \\
=0.92(\mathrm{~ns})\end{array}$ & $\mathrm{nm}$ & $\begin{array}{l}\text { age, sex, ancestry, } \\
\text { usual residence }\end{array}$ \\
\hline $\begin{array}{l}\text { Tajima, } 1085 \\
{[66]}\end{array}$ & Japan & $\begin{array}{l}93 \text { colorectal } \\
\text { cancer }\end{array}$ & 186 hospital & $\mathrm{ffq}$ & $\begin{aligned} \text { yogurt: } & \mathrm{OR}_{\mathrm{C}} \\
& \mathrm{OR}_{\mathrm{R}} \\
\text { cheese: } & \mathrm{OR}_{\mathrm{C}} \\
& \mathrm{OR}_{\mathrm{R}} \\
\text { calcium: } & \mathrm{OR}_{\mathrm{C}} \\
& \mathrm{OR}_{\mathrm{R}}\end{aligned}$ & $\begin{array}{l}=1.5(\mathrm{~ns}) \\
=1.7(\mathrm{~ns}) \\
=1.4(\mathrm{~ns}) \\
=1.2(\mathrm{~ns}) \\
=1.1(\mathrm{~ns}) \\
=0.5(\mathrm{~ns})\end{array}$ & $\mathrm{nm}$ & age, sex \\
\hline $\begin{array}{l}\text { Macquart- } \\
\text { Moulin, } 1986 \\
{[67]}\end{array}$ & $\begin{array}{l}\text { France, } \\
\text { Marscilles } \\
\text { region }\end{array}$ & $\begin{array}{l}399 \text { colorectal } \\
\text { cancer }\end{array}$ & 390 houpital & $\begin{array}{l}\text { diet hist } \\
(i=158)\end{array}$ & $\begin{array}{l}\text { chcese: OR } \\
\text { milk: } \text { OR } \\
\text { calcium: OR }\end{array}$ & $\begin{array}{l}=0.9(\mathrm{~ns}) \\
=0.7(\mathrm{ptr}<0.05) \\
=0.7(\mathrm{~ns})\end{array}$ & $\mathrm{nm}$ & $\begin{array}{l}\text { age, sex, calories, } \\
\text { weight }\end{array}$ \\
\hline $\begin{array}{l}\text { Macquart- } \\
\text { Moulin, } 1987 \\
{[68]}\end{array}$ & $\begin{array}{l}\text { France, } \\
\text { Marseilles } \\
\text { region }\end{array}$ & $\begin{array}{l}223 \text { colorectal } \\
\text { adenoma and } \\
29 \text { villous } \\
\text { polyps }\end{array}$ & 238 huspital & $\begin{array}{l}\text { diet hist } \\
(i=158)\end{array}$ & $\begin{array}{l}\text { cheese: OR } \\
\text { milk: } \quad \text { OR } \\
\text { calcium: } O R\end{array}$ & $\begin{array}{l}=1.2(\mathrm{~ns}) \\
=0.9(\mathrm{~ns}) \\
=1.2(\mathrm{~ns})\end{array}$ & $\begin{array}{l}\text { median: } \\
\text { men }=831 \\
\text { women }=772\end{array}$ & $\begin{array}{l}\text { age, sex, calories, } \\
\text { weight }\end{array}$ \\
\hline $\begin{array}{l}\text { Tuyns, } 1987 \\
{[77]}\end{array}$ & Belgium & $\begin{array}{l}818 \text { colorectal } \\
\text { cancer }\end{array}$ & 2,851 population & diet hist & $\begin{array}{r}\text { calcium: }{ }^{O R_{C}} \\
\mathrm{OR}_{\mathrm{R}}\end{array}$ & $\begin{array}{l}=1.3(\mathrm{~ns}) \\
=1.0\end{array}$ & mean: 700 & $\begin{array}{l}\text { age, scx, province, } \\
\text { calories }\end{array}$ \\
\hline $\begin{array}{l}\text { Tuyns, } 1988 \\
{[69]}\end{array}$ & Belgium & $\begin{array}{l}818 \text { colorectal } \\
\text { cancer }\end{array}$ & 2,851 population & diet hist & $\begin{array}{cl}\text { milk: } & \mathrm{OR}_{\mathrm{C}} \\
& \mathrm{OR}_{\mathrm{R}} \\
\text { cheese: } & \mathrm{OR}_{\mathrm{C}} \\
& \mathrm{OR}_{\mathrm{R}}\end{array}$ & $\begin{array}{l}=1.8(\mathrm{ptr}<0.0001) \\
=1.7(\mathrm{ptr}<0.01) \\
=1.0 \\
=1.0\end{array}$ & & age, sex, province \\
\hline
\end{tabular}




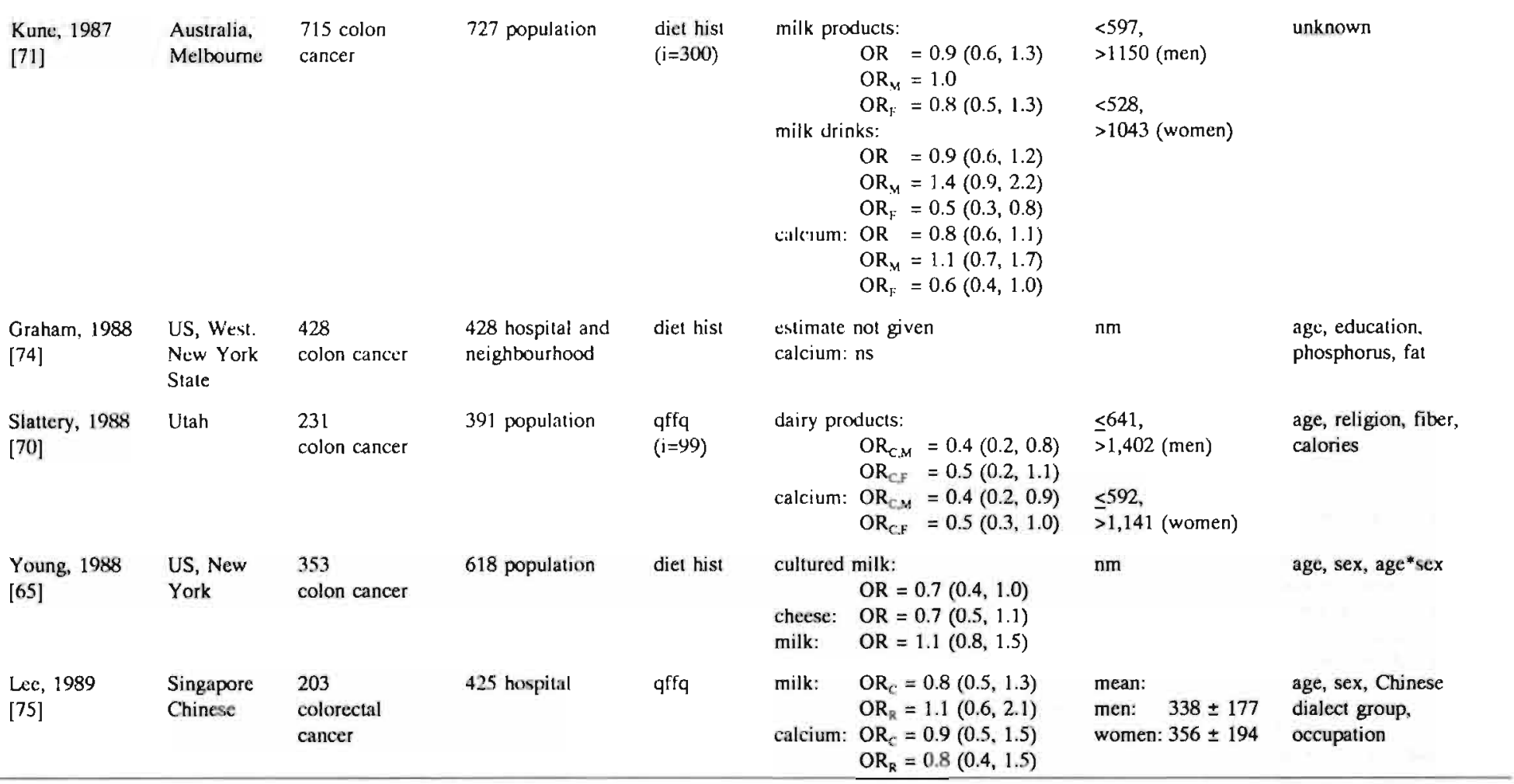

$\mathrm{C}=$ colon cancer or polyps; $\mathrm{R}=$ rectal cancer or polyps; $\mathrm{F}=$ female; $\mathrm{M}=$ male; $\mathrm{ptr}=\mathrm{p}$ for trend; $\mathrm{nm}=$ not mentioned; (q)ffq =(semi quantitative) food frequency questionaire; $\mathrm{i}$ = number of items; diet hist = dielary history. 
Table 2.1b. Dairy products, calcium and colorectal polyps and colorectal cancer: 12 case-control studies 1990-1993.

\begin{tabular}{|c|c|c|c|c|c|c|c|c|}
\hline Author, year & Population & $\begin{array}{l}\text { No. of cases/ } \\
\text { end point }\end{array}$ & $\begin{array}{l}\text { Controls/ } \\
\text { source }\end{array}$ & $\begin{array}{l}\text { Dietary } \\
\text { method }\end{array}$ & \multicolumn{2}{|c|}{$\begin{array}{l}\text { Risk estimates (OR) highest vs } \\
\text { lowest intake }\end{array}$} & $\begin{array}{l}\text { Calcium intake } \\
\text { (or contrast) } \\
\text { among controls } \\
\text { (mg/day) }\end{array}$ & Adjusted for \\
\hline $\begin{array}{l}\text { Negri, } 1990 \\
{[8.3]}\end{array}$ & Italy & $\begin{array}{l}910 \\
\text { colorectal cancer }\end{array}$ & $\begin{array}{l}1,032 \\
\text { hospital }\end{array}$ & $\mathrm{ffq}(i=29)$ & $\begin{array}{l}\text { milk: } \\
\text { cheese: } \\
\text { calcium: }\end{array}$ & $\begin{array}{l}\mathrm{OR}=1.0(0.7,1.3) \\
\mathrm{OR}_{\mathrm{C}}=1.1(0.8,1.4) \\
\mathrm{OR}_{\mathrm{R}}=1.3(1.0,1.8) \\
\mathrm{OR}_{\mathrm{C}}=1.1(0.8,1.6) \\
\mathrm{OR}_{\mathrm{R}}=1.2(0.8,1.9)\end{array}$ & $\mathrm{nm}$ & $\begin{array}{l}\text { age, sex, education, } \\
\text { residence, pasta, rice, } \\
\text { meal, green vegelables. } \\
\text { coffee }\end{array}$ \\
\hline $\begin{array}{l}\text { Berito, } 1990 \\
{[90]}\end{array}$ & Majorca & $\begin{array}{l}286 \\
\text { colorcctal cancer }\end{array}$ & $\begin{array}{l}499 \\
\text { population } \\
\text { and } \\
\text { hospital }\end{array}$ & $\mathrm{ffq}$ & $\begin{array}{r}\text { dajry pror } \\
\mathrm{O} \\
\mathrm{O} \\
\mathrm{O} \\
\mathrm{O}\end{array}$ & 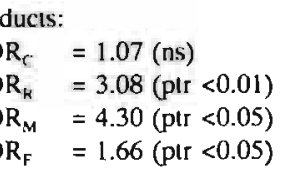 & $\mathrm{nm}$ & $\begin{array}{l}\text { age, sex, weight, SES, } \\
\text { physical activity, no. } \\
\text { meals per day, cereals, } \\
\text { potatoes, meat, } \\
\text { vegetables, eggs }\end{array}$ \\
\hline $\begin{array}{l}\text { Whiltemore, } \\
1990 \\
{[85]}\end{array}$ & $\begin{array}{l}\text { China and } \\
\text { Chinese in } \\
\text { US }\end{array}$ & $\begin{array}{l}905 \\
\text { colorectal cancer }\end{array}$ & $\begin{array}{l}2,488 \\
\text { population }\end{array}$ & $\begin{array}{l}\text { diet hist } \\
(i=84)\end{array}$ & calcium: & $\begin{array}{l}\mathrm{OR}_{\zeta}<1.0(\mathrm{~ns}) \\
\mathrm{OR}_{\mathrm{R}}<1.0(\mathrm{p}<0.01)\end{array}$ & $\mathrm{nm}$ & age, sex, saturated fat \\
\hline $\begin{array}{l}\text { Benito, } 1991 \\
{[91]}\end{array}$ & Majorca & $\begin{array}{l}286 \text { colorectal } \\
\text { cancer }\end{array}$ & $\begin{array}{l}499 \\
\text { population } \\
\text { and hospital }\end{array}$ & $\mathrm{ffq}$ & calcium: & $\mathrm{OR}=1.48(\mathrm{~ns})$ & $\mathrm{nm}$ & - \\
\hline $\begin{array}{l}\text { Kune, } 1991 \\
{[92]}\end{array}$ & $\begin{array}{l}\text { Australia, } \\
\text { Melbourne }\end{array}$ & $\begin{array}{l}49 \text { colorectal } \\
\text { adenoma } \geq 1 \mathrm{~cm}\end{array}$ & $\begin{array}{l}727 \\
\text { population }\end{array}$ & $\begin{array}{l}\text { die! hist } \\
(i=300)\end{array}$ & milk drin & $\begin{array}{l}\mathrm{ks:} \\
\mathrm{OR}_{M}=3.7(1.5,9.5) \\
\mathrm{OR}_{\mathrm{F}}=0.7(0.2,2.0)\end{array}$ & $\mathrm{nm}$ & $\mathrm{nm}$ \\
\hline $\begin{array}{l}\text { Pctcrs, } 1992 \\
{[82]}\end{array}$ & $\begin{array}{l}\text { US, Los } \\
\text { Angeles }\end{array}$ & 746 colon cancer & $\begin{array}{l}746 \\
\text { population }\end{array}$ & $q f f q(i=139)$ & $\begin{array}{l}\text { yogurt: } \\
\text { calcium: }\end{array}$ & $\begin{array}{l}\text { OR per } 10 \text { grams } \\
\begin{aligned}=0.8(0.7,1.0) \\
\text { OR }=0.4(0.3,0.7)\end{aligned}\end{array}$ & $1,049 \pm 504$ & $\begin{array}{l}\text { age, sex, (calcium), } \\
\text { sources of calories, } \\
\text { family history, weight, } \\
\text { physical activity, } \\
\text { (pregnancy history) }\end{array}$ \\
\hline $\begin{array}{l}\text { Bidoli, } 1992 \\
{[84]}\end{array}$ & $\begin{array}{l}\text { North- } \\
\text { eastern Italy }\end{array}$ & $\begin{array}{l}248 \\
\text { colorectal cancer }\end{array}$ & 699 hospital & diel hist & $\begin{array}{l}\text { milk: } \\
\text { checse: }\end{array}$ & $\begin{array}{l}\mathrm{OR}_{\mathrm{C}}=1.0 \\
\mathrm{OR}_{\mathrm{R}}=1.0 \\
\mathrm{OR}_{\mathrm{C}}=1.4(\mathrm{ptr}=0.17) \\
\mathrm{OR}_{\mathrm{R}}=1.6(\mathrm{ptr}=0.08)\end{array}$ & $\mathrm{nm}$ & $\begin{array}{l}\text { age, scx, ses, bread, } \\
\text { polenta, eggs, tomatoes }\end{array}$ \\
\hline
\end{tabular}




\begin{tabular}{|c|c|c|c|c|c|c|c|c|}
\hline $\begin{array}{l}\text { Iscovich, } 1992 \\
{[88]}\end{array}$ & $\begin{array}{l}\text { Argentina, } \\
\text { La Plata } \\
\text { area, }\end{array}$ & 110 colon cancer & $\begin{array}{l}220 \\
\text { ntighbour- } \\
\text { hood }\end{array}$ & $\begin{array}{l}\text { diet hist } \\
(i=140)\end{array}$ & $\begin{array}{r}\text { dairy prod } \\
\text { OR } \\
\text { whole mil } \\
\text { OR } \\
\text { cheese: } \\
\text { OR }\end{array}$ & $\begin{array}{l}=3.0(1.2,7.6) \\
=1.6(0.8,3.1) \text { (uv) } \\
=1.9(0.9,4.0) \text { (uv) }\end{array}$ & $\mathrm{nm}$ & $\begin{array}{l}\text { education, bmi, meat, } \\
\text { fish, eggs, vegetables }\end{array}$ \\
\hline $\begin{array}{l}\text { Zaridze, } 1993 \\
{[86]}\end{array}$ & $\begin{array}{l}\text { Russia, } \\
\text { Moscow, } \\
\text { Khabarovsk }\end{array}$ & $\begin{array}{l}217 \\
\text { colorectal cancer }\end{array}$ & $\begin{array}{l}217 \\
\text { population } \\
\text { and } \\
\text { neighbour- } \\
\text { hood }\end{array}$ & diet hist & $\begin{array}{l}\text { calcium: } \\
\text { milk: }\end{array}$ & $\begin{array}{l}\mathrm{OR}=0.5(0.2,1.1) \\
\mathrm{OR}=0.5(0.3,1.0)\end{array}$ & $\begin{array}{l}\text { men: } \\
<747,9 \\
>1,477,9 \\
\text { women: } \\
<890,4 \\
>1,545,1\end{array}$ & energy intake, education \\
\hline $\begin{array}{l}\text { Meyer and } \\
\text { While, } 1493 \\
{[87]}\end{array}$ & $\begin{array}{l}\text { US, } \\
\text { Washinglon } \\
\text { Slatc }\end{array}$ & 424 colon cancer & $\begin{array}{l}414 \\
\text { population }\end{array}$ & $\begin{array}{l}\mathrm{ffq} \\
(i=71)\end{array}$ & calcium: & $\begin{array}{l}O R_{M}=1.1(0.9,1.4) \\
O R_{F}=0.7(0.6,1.0)\end{array}$ & median: 896 & $\begin{array}{l}\text { age, interviewer, calories, } \\
\text { alcohol, fiber }\end{array}$ \\
\hline $\begin{array}{l}\text { Steinmetz and } \\
\text { Potter, } 1993 \\
{[89]}\end{array}$ & $\begin{array}{l}\text { Australia } \\
\text { Adelaidc }\end{array}$ & 220 colon cancer & $\begin{array}{l}438 \\
\text { population }\end{array}$ & $\begin{array}{l}f f q \\
(i=141)\end{array}$ & \multicolumn{2}{|c|}{ 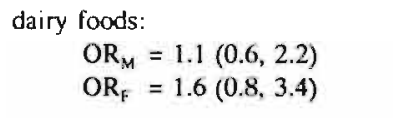 } & $\mathrm{nm}$ & $\begin{array}{l}\text { age, sex, occupation, } \\
\text { bmi, alcohol, (age at first } \\
\text { live birth) }\end{array}$ \\
\hline $\begin{array}{l}\text { Benilo. 1903 } \\
{[93]}\end{array}$ & $\begin{array}{l}\text { Spain. } \\
\text { Majorca }\end{array}$ & $\begin{array}{l}101 \text { coloreclal } \\
\text { adenoma }\end{array}$ & $\begin{array}{l}242 \\
\text { population }\end{array}$ & ffq & $\begin{array}{l}\text { dairy prod } \\
\text { cheese: } \\
\text { calciumn: } \\
\text { milk: }\end{array}$ & $\begin{aligned} \text { cts: } & \\
\text { OR } & =1.2(\mathrm{ptr}>0.05) \\
\text { OR } & =0.7(\mathrm{ptr}>0.05) \\
\text { OR } & =0.9(\mathrm{ptr}=0) \\
\text { OR } & =1.0(\mathrm{ptr}>0.05)\end{aligned}$ & $\begin{array}{l}\text { median cases } \\
\text { and controls: } \\
725\end{array}$ & $\begin{array}{l}\text { age, sex, calories, } \\
\text { physical activity, rural } \\
\text { residence }\end{array}$ \\
\hline
\end{tabular}

$\mathrm{C}=$ colon cancer or polyps; $\mathrm{R}=$ rectal cancer or polyps; $\mathrm{F}=$ female; $\mathrm{M}=$ male; $\mathrm{ptr}=\mathrm{p}$ for trend; $\mathrm{nm}=$ not mentioned; $(q) \mathrm{ff} q=(\mathrm{semi}$ quantitative) food frequency questionaire; $i=$ number of items; diet hist = dietary history. 
Table 2.2a. Dairy products, calcium and colorectal cancer: 4 prospective studies 1975-1989.

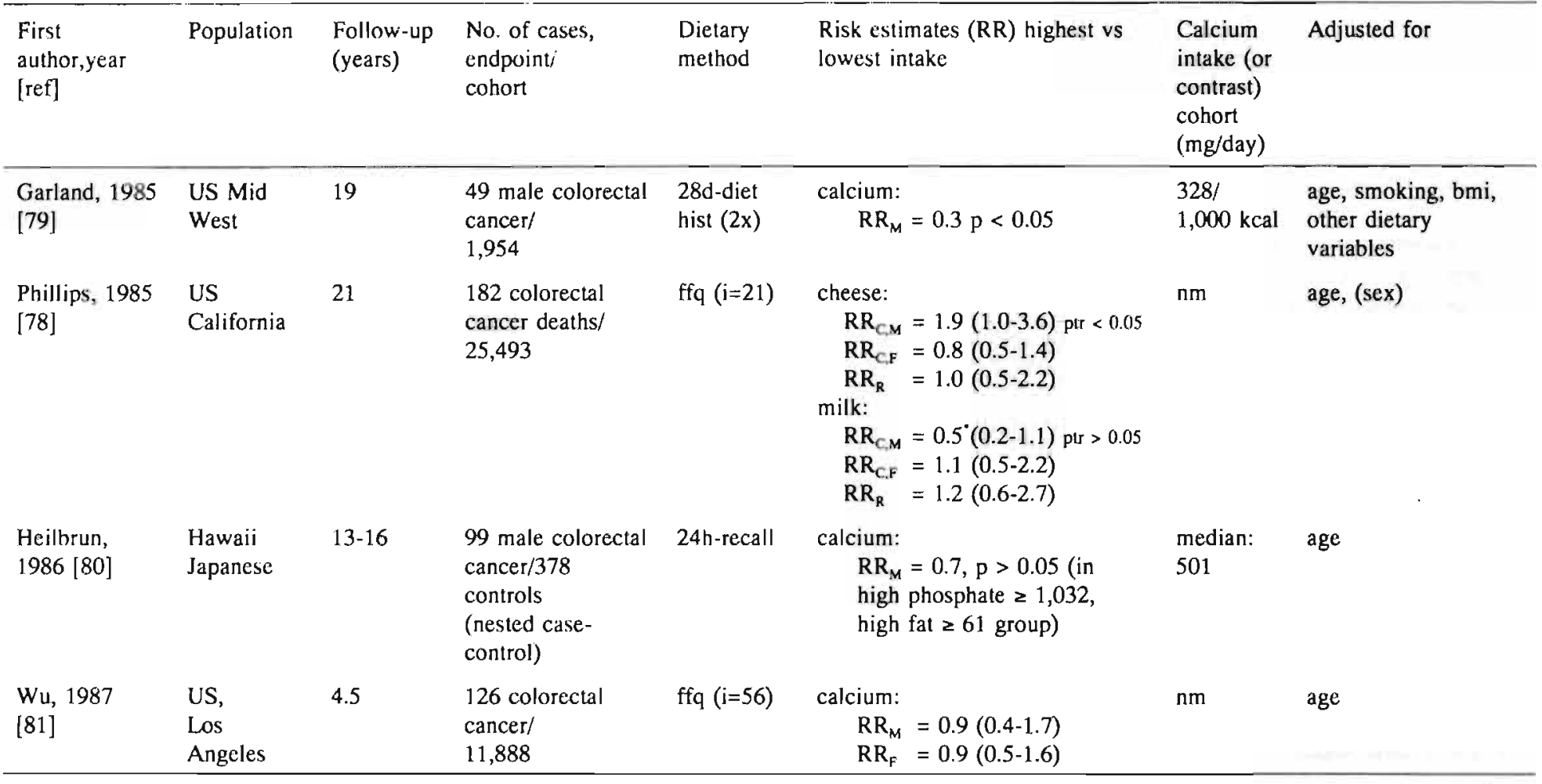

$\mathrm{C}=$ colon cancer or colon polyps; $\mathrm{R}=$ rectal cancer or rectal polyps; $\mathrm{F}=$ female; $\mathrm{M}=$ male; ${ }^{-}=$based on small number of deaths; $\mathrm{ptr}=\mathrm{p}$ for trend; $\mathrm{nm}=$ not mentioned; $(\mathrm{q}) \mathrm{ffq}=($ semi quantitative $)$ food frequency questionaire; $\mathrm{i}$ = number of items; diet hist = dietary history. 
Table 2.2b. Dairy products, calcium and colorectal cancer: 4 prospective studies 1990-1993.

\begin{tabular}{|c|c|c|c|c|c|c|c|}
\hline $\begin{array}{l}\text { First } \\
\text { author,year } \\
\text { [ref] }\end{array}$ & Population & $\begin{array}{l}\text { Follow-up } \\
\text { (years) }\end{array}$ & $\begin{array}{l}\text { No. of cases, } \\
\text { endpoint/ } \\
\text { cohort }\end{array}$ & $\begin{array}{l}\text { Dietary } \\
\text { method }\end{array}$ & $\begin{array}{l}\text { Risk estimates (RR) highest vs } \\
\text { lowest intake }\end{array}$ & $\begin{array}{l}\text { Calcium } \\
\text { intake (or } \\
\text { contrast) } \\
\text { cohort } \\
\text { (mg/day) }\end{array}$ & Adjusted for \\
\hline $\begin{array}{l}\text { Stemmermann, } \\
1990[94]\end{array}$ & $\begin{array}{l}\text { US, } \\
\text { Japanese }\end{array}$ & $19-22$ & $\begin{array}{l}323 \text { male } \\
\text { colon } \\
\text { cancer } / 7,472\end{array}$ & 24h-recall & $\begin{aligned} \text { calcium: } & \\
\mathrm{RR}_{M} & =0.6(0.4-0.9) \text { (sigmoid) } \\
\mathrm{RR}_{\mathrm{M}} & =0.8(0.6-1.1) \text { (total colon) }\end{aligned}$ & $\begin{array}{l}\text { age-adjusted } \\
\text { mean non- } \\
\text { cases: } 503\end{array}$ & age \\
\hline $\begin{array}{l}\text { Willett, } 1990 \\
\text { [131] }\end{array}$ & US & 6 & $\begin{array}{l}150 \text { female } \\
\text { colon cancer/ } \\
88,751\end{array}$ & qffq $(i=61)$ & 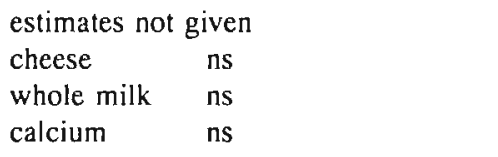 & $\mathrm{nm}$ & unknown \\
\hline
\end{tabular}

$\mathrm{C}=$ colon cancer or colon polyps; $\mathrm{R}=$ rectal cancer or rectal polyps; $\mathrm{F}=$ female; $\mathrm{M}=$ male; ${ }^{*}=$ based on small number of deaths; $\mathrm{ptr}=\mathrm{p}$ for trend; $\mathrm{nm}=$ not mentioned; $(\mathrm{q}) \mathrm{ffq}=($ semi quantitative $)$ food frequency questionaire; $\mathrm{i}=$ number of items; diet hist = dietary history. 
Cheese consumption was addressed in two Italian case-control studies: ${ }^{83,84}$ nonsignificant positive associations were found.

In about half of the studies which mentioned milk and/or calcium intake, inverse associations were observed. ${ }^{52.85 \times 7}$ An important observation was the clear doseresponse effect of calcium in the large US case-control study by Peters et al..$^{82}$ In an other US case-control study an inverse association with calcium intake was observed for women only, for men a non-significant positive association was observed. ${ }^{87}$ In a relatively small Argentinean study, a non-significant positive association was observed for whole milk consumption, while the intake of dairy products in general significantly increased risk. ${ }^{88}$ Positive associations with the intake of dairy foods or calcium and colon or rectum cancer risk were observed in two other studies. ${ }^{89,91,91}$

Two case-control studies on colorectal polyps were conducted. The results of a small study in Australia indicated a significant positive association with milk drinks among men, while in women a non-significant inverse association was found. ${ }^{92}$ An Italian study found no important association with dairy product, milk or calcium intake. ${ }^{93}$ In the same study, a non-significant inverse association with cheese consumption was found. ${ }^{93}$

None of the prospective studies published after 1989 addressed fermented dairy products. In three of the four prospective studies addressing milk and/or calcium, an inverse association was observed. ${ }^{94.96}$ In the study conducted by Stemmermann et al. in a Japanese Hawaiian population using a $24 \mathrm{~h}$ recall method the association with calcium and sigmoid cancer was significant $(R R=0.6,95 \% \mathrm{CI}=0.4-0.9) .{ }^{94}$ For the colon as a whole this association was less strong and not significant $(R R=0.8)$. In the most recent study published, the Iowa Women Health Study, calcium from supplements (mean intake among non-cases: $283 \mathrm{mg} / \mathrm{day}$ ) was associated with risk $(\mathrm{RR}=0.66,95 \% \mathrm{Cl}=0.43-1.02)$, while only a very weak inverse association was observed with calcium from dietary origin ( $\mathrm{RR}=0.95,95 \% \mathrm{CI}=0.57-1.61)$ (mean intake among non-cases: $835 \mathrm{mg} /$ day). ${ }^{*}$

The diversity in findings among case-control as well as prospective studies may be partially explained by differences in populations, differences in methodology and differences in the bacterial strains used to ferment dairy products. Most studies are conducted among populations with a relatively low and homogeneous dairy product intake. Only a few studies addressed the interactions with dairy products, calcium and other nutrients as fat or fiber, or focused on different stages of tumor development as the outcome or stratified disease according to subsites within the colon. 


\section{Experimental studies}

\section{Lactic acid bacteria}

Diet affects the composition of the intestinal flora, and carcinogenic substances derived from food may be produced by bacteria within the colon. ${ }^{21.22}$ It has been suggested that lactic acid bacteria, which belong to the normal intestinal microflora, contribute to the stabilization of the bacterial flora and maintain resistance against pathogens. $^{97}$

Since the oral administration of commercial and simulated yogurt containing Lactobacillus bulgaricus and Streptococcus thermophilus inhibited initial Ehrlich ascites tumor growth in mice ${ }^{98}$ and supplements with Lactobacillus acidophilus delayed the occurrence of DMH-induced colon cancer in rats, ${ }^{99}$ several short-term animal and human experimental studies have been conducted studying the mechanisms by which suppletion of lactobacilli might exert anti-carcinogenic properties. ${ }^{97}$

Three different mechanisms have been suggested (see Table 2.3). Lactobacilli might modulate the colonic flora, thereby influencing enzyme activity and reducing the conversion of procarcinogens to carcinogens in the colon. The activity of specific bacterial enzymes is elevated by a high meat, western-type diet. ${ }^{53}$

Supplementation of the human diet with milk containing viable $L$. acidophilus of human origin, which is bile resistant, caused a significant decline in faecal bacterial enzymes supposed to be involved in the carcinogenic process, such as $\beta$-glucuronidase, 7 - $\alpha$-dehydroxylase, nitroreductase and azoreductase ${ }^{53,100}$ It is not clear whether ingested lactobacilli reduce enzyme activity due to implantation of the viable strain or to suppression of enzyme activity in other intestinal bacteria by viable and unviable strains. ${ }^{101}$

The second hypothesized mechanism involves a stimulation of the immune respons, locally as well as systematically. Oral administration of milk containing $L$. bulgaricus or $L$. casei to mice ${ }^{102}$ was shown to activate lymphocytes and macrophages. Addition of yogurt to human peripheral blood lymphocyte cultures stimulated by a mitogen (Con-Canavalin A) ${ }^{103}$ increases the production of $\gamma$-interferon, a cytokine which has anti-proliferative properties and has been able to activate Natural Killer cells.

Thirdly, in vitro studies have shown that lactic acid bacteria have the ability to absorb cooked food mutagens. ${ }^{104}$ Human experimental studies have shown that intake of $L$. acidophilus significantly reduced mutagen excretion after consumption of fried meat. ${ }^{105}$ 
Table 2.3 Mechanisms suggested for the protective effect of fermented dairy products on colorectal cancer risk.

\begin{tabular}{|c|c|c|c|}
\hline First author, year [ref] & Human/animal & Strain & Observations \\
\hline \multicolumn{4}{|l|}{$\begin{array}{l}\text { Modulation colonic } \\
\text { flora }\end{array}$} \\
\hline $\begin{array}{l}\text { Ayebo, } 1980[132] \\
\text { Goldin, } 1984[53] \\
\text { Marteau, } 1990[100] \\
\text { Lidbeck, } 1991[133]\end{array}$ & $\begin{array}{l}\text { healthy humans } \\
\text { colon cancer patients }\end{array}$ & L. acidophilus & $\begin{array}{l}\beta \text {-glucuronidase }-(3 \mathrm{x}) \\
\text { nitroreductase }-(2 \mathrm{x}) \\
\text { azorcductase }-(1 \mathrm{x}) \\
\beta \text {-glucosidase }-(1 \mathrm{x})\end{array}$ \\
\hline \multicolumn{4}{|l|}{ Immunology } \\
\hline Perdigon, 1986 [102] & mice & L. acidophilus & macrophages + \\
\hline De Simone, 1986 [103] & human lymphocytes & L. bulgaricus & $\gamma$-interferon + \\
\hline \multicolumn{4}{|l|}{ Mutagen absorption } \\
\hline $\begin{array}{l}\text { Zhang and Ohta, } 1991 \\
\text { [104] }\end{array}$ & in vitro & $\begin{array}{l}\text { L. acidophilus, } \\
\text { B. bifidum, S. cremoris }\end{array}$ & $\begin{array}{l}\text { food mutagen binding } \\
\text { capacity }+\end{array}$ \\
\hline Lidbeck, 1992 [105] & healthy humans & L. acidophilus & $\begin{array}{l}\text { faecal mutagen } \\
\text { binding capacity + }\end{array}$ \\
\hline
\end{tabular}

+ increase; - decrease.

For Lactobacilli to exert an effect on the intestinal microflora, survival through the intestinal tract might be important. Robins-Brown and Levine ${ }^{106}$ have shown that L. acidophilus and L. bulgaricus, when taken with milk, have the ability to pass through the stomach in equal numbers. Jejunal fluid samples were taken from volunteers at varying intervals and lactobacilli were cultured on a selective medium. $L$. acidophilus was recovered from more samples and in higher counts that $L$. bulgaricus. When given $500 \mathrm{ml}$ L. acidophilus fermented milk per day, within one week the number of lactobacilli increased markedly in human volunteers. ${ }^{107,108}$ However, one week after supplementation was stopped, the numbers of lactobacilli had decreased to almost the same levels as before administration. This implies that colonization is not established and consumption of lactobacilli might need to be at least very frequent to exert an effect.

Although promising, experimental research on lactic acid bacteria and fermented dairy products is preliminary. 


\section{Calcium}

Several biological mechanisms have been suggested for a protective effect of calcium in colon carcinogenesis. Calcium ${ }^{109}$ or -more recently- calciumphosphate," might reduce colorectal cancer risk by binding bile acids and free fatty acids. thereby diminishing the proliferative stimulus of these compounds on the colon mucosa. This hypothesis has been supported by animal experiments. ${ }^{1\left(\mu_{1}, 11,112\right.}$ An alternative hypothesis, based on in vitro studies in human epithelial cells, ${ }^{11-116}$ proposes that calcium might inhibit the proliferation of colonic epithelial cells directly by inducing differentiation. Furthermore, administration of calcium reduced chemical carcinogen-induced tumor yield in rodents, ${ }^{117-119}$ and reduced Ki-ras $G$ to A mutations in colorectal neoplasms in rats. ${ }^{120}$ For calcium to influence cell proliferation directly, absorption into the cells is necessary. Vitamin D increases calcium absorption. Experimental studies suggest inhibition of cell proliferation by vitamin $D$, which might be due to vitamin $D$ itself or its effect on calcium absorption. ${ }^{40}$

Before 1990, 4 out of 6 small trials, which were not placebo-controlled, have shown that supplemental calcium reduces cell proliferation in man (Table 2.4a). ${ }^{113,114,116.131}$ Lipkin and Newmark reported the first trial in 10 persons with a family history of colon cancer. ${ }^{113}$ Calcium $(1250 \mathrm{mg}$ administered as calciumcarbonate) was added to their normal diets for a period of three months and rectal biopsies were obtained before and after supplementation. The average level of proliferation of epithelial cells in the colon was lower after calcium supplementation. However, since no control group was used, these changes could be attributable to temporal fluctuations in cell proliferation. Furthermore, it was unclear whether all subjects experienced a reduction in cell proliferation or whether this was confined to those individuals whose levels were initially the highest and who might therefore be expected to show reduced levels during a repeated examination through chance variation. In a small randomized, placebo-controlled trial no decrease in proliferation activity was noticed using the same method of proliferation assessment. $^{122}$

The baseline intake of calcium, as assessed through dietary questionnaires, was similar among the studies and was usually slightly less than the adult recommended dietary allowance (RDA) of $800 \mathrm{mg} /$ day. Doses of supplementation were comparable between studies and the tritiated thymidine method was used in all studies to assess the labelling index. The labelling index reflects the proliferative state of the mucosa: the more proliferating cells, the higher the labelling index. In the study by Gregoire and colleagues the duration of supplement use was shorter than in the other studies. ${ }^{122}$ However, since the tumover rate of the rectal mucosa is a few days, a significant effect was demonstable after as little as one month. ${ }^{123}$ 
Table 2.4a Human experimental studies on calcium and distal colonic epithelial proliferation 1985-1989.

\begin{tabular}{|c|c|c|c|c|c|c|c|}
\hline \multirow{2}{*}{$\begin{array}{l}\text { First author } \\
\text { year } \\
\text { [ref] }\end{array}$} & \multirow[t]{2}{*}{ Design } & \multirow{3}{*}{$\begin{array}{l}\text { Study } \\
\text { population/ } \\
\begin{array}{l}\text { No. of } \\
\text { subjects }\end{array} \\
\text { HNPCC/10 }\end{array}$} & \multirow{3}{*}{$\begin{array}{l}\text { Ca- } \\
\text { diet } \\
\text { mg/ } \\
\text { day }\end{array}$} & \multicolumn{2}{|c|}{ Ca-supplement ${ }^{\circ}$} & \multirow{3}{*}{$\begin{array}{l}\text { Method } \\
\mathrm{T}^{\cdots}\end{array}$} & \multirow{2}{*}{$\begin{array}{l}\text { Change } \\
\text { in } \\
\text { labelling } \\
\text { index }\end{array}$} \\
\hline & & & & $\begin{array}{l}\text { dose } \\
\text { g/day }\end{array}$ & $\begin{array}{l}\text { duration } \\
\text { /months }\end{array}$ & & \\
\hline $\begin{array}{l}\text { Lipkin, } 1985 \\
{[113]}\end{array}$ & $\begin{array}{l}\text { uncon- } \\
\text { trolled }\end{array}$ & & & 1.25 & $2 \cdot 3$ & & - \\
\hline $\begin{array}{l}\text { Buset, } 1986 \\
{[114]}\end{array}$ & uncontrolled & $\mathrm{FCC} / 5$ & $\mathrm{~nm}$ & 1.5 & $1-2$ & $\mathrm{~T}$ & - \\
\hline $\begin{array}{l}\text { Buset, } 1986 \\
{[114]}\end{array}$ & uncontrolled & $\begin{array}{l}\text { sporadic } \\
\text { adenoma/3 }\end{array}$ & $\mathrm{nm}$ & 1.5 & $1-2$ & $\mathrm{~T}$ & 0 \\
\hline $\begin{array}{l}\text { Rozen, } 1989 \\
{[121]}\end{array}$ & uncontrolled & $\begin{array}{l}\text { FCC and } \\
\text { sporadic } \\
\text { adenoma/35 }\end{array}$ & $\mathrm{nm}$ & $\begin{array}{l}1.3- \\
1.5\end{array}$ & 3 & $\mathrm{~T}$ & - \\
\hline $\begin{array}{l}\text { Lipkin, } 1989 \\
\text { [116] }\end{array}$ & uncontrolled & HNPCC/21 & 700 & $\begin{array}{l}1.3- \\
1.5\end{array}$ & $3-4$ & $\mathrm{~T}$ & - \\
\hline $\begin{array}{l}\text { Lipkin, } 1989 \\
\text { [116] }\end{array}$ & uncontrolled & $\mathrm{FAP} / 7$ & 700 & $\begin{array}{l}1.3- \\
1.5\end{array}$ & $3-4$ & $\mathrm{~T}$ & $\begin{array}{l}\text { variable } \\
\text { response }\end{array}$ \\
\hline $\begin{array}{l}\text { Gregoire, } \\
1989 \text { [122] }\end{array}$ & $\begin{array}{l}\text { placebo- } \\
\text { controlled }\end{array}$ & $\begin{array}{l}\text { colonic } \\
\text { resection/30 }\end{array}$ & 669 & 1.2 & 1 & $\mathrm{~T}$ & $\begin{array}{l}+ \\
(p=0.06)\end{array}$ \\
\hline
\end{tabular}

* Calcium carbonate unless otherwise indicated; ** Without a placebo control group;

*** Labelling index determined using tritiated thymidine; - decrease; + increase; 0 no effect; FCC Family history of Colorectal Cancer; HNPCC Family members of Heriditary NonPolyposis Colon Cancer; FAP Familial Adenomatous Polyposis; $\mathrm{nm}=$ not mentioned.

An important striking difference between the trials mentioned was that the reported baseline labelling index in the trials by Lipkin and colleagues $(16.7 \%$, $12.1 \%$ and $9.1 \%$ respectively) ${ }^{11.3}$ was twice as high as those reported by Gregoire et al. $(4.9 \%)^{122}$ and Rozen et al. $(5.3 \%)^{121}$

After 1989, 7 different research groups publiced the results of 11 trials (Table 2.4b). In five trials a significant reduction in cell proliferation could be determined, ${ }^{123-126}$ in two a non significant reduction was observed, ${ }^{123}$ two did not observe any reduction ${ }^{127,128}$ and in two an increase in proliferation was observed. ${ }^{129}$ In the study by Barsoum et al., ${ }^{124}$ a stathmokinetic method examining colonic crypt cell production rate was used to assess cell proliferation. This method takes the cell cycle time, growth fraction and the crypt cell population into account. ${ }^{124}$ Kleibeuker et al. ${ }^{29}$ and $\mathrm{O}^{\prime}$ Sullivan et al. ${ }^{125}$ determined labelling index using 5-bromodeoxyuridine and immunohistochemistry. Both studies did not use a placebo-treated control group. 
Table 2.4b Human experimental studies on calcium and distal colonic epithelial proliferation 1990-1993.

\begin{tabular}{|c|c|c|c|c|c|c|c|}
\hline \multirow{2}{*}{$\begin{array}{l}\text { First author, } \\
\text { year } \\
\text { [ref] }\end{array}$} & \multirow[t]{2}{*}{ Design } & \multirow{2}{*}{$\begin{array}{l}\text { Study } \\
\text { population/ } \\
\text { No. of } \\
\text { subjects }\end{array}$} & \multirow{2}{*}{$\begin{array}{l}\text { Ca-diet } \\
\mathrm{mg} / \text { day }\end{array}$} & \multicolumn{2}{|c|}{ Ca-supplement } & \multirow[t]{2}{*}{ Method } & \multirow{2}{*}{$\begin{array}{l}\text { Change } \\
\text { in } \\
\text { labelling } \\
\text { index }\end{array}$} \\
\hline & & & & $\begin{array}{l}\text { dose } \\
\text { g/day }\end{array}$ & $\begin{array}{l}\text { duration } \\
\text { /months }\end{array}$ & & \\
\hline $\begin{array}{l}\text { Stern, } 1990 \\
{[127]}\end{array}$ & $\begin{array}{l}\text { randomized, } \\
\text { placebo- } \\
\text { controlled }\end{array}$ & FAP/31 & 1,102 & 1.2 & 9 & $\mathrm{~T}$ & 0 \\
\hline $\begin{array}{l}\text { Barsoum, } \\
1992[126]\end{array}$ & $\begin{array}{l}\text { placebo- } \\
\text { controlled, } \\
\text { double blind }\end{array}$ & adenoma/14 & $\mathrm{nm}$ & 1.3 & 2 & $\mathrm{C}$ & - \\
\hline $\begin{array}{l}\text { Wargovich, } \\
1992 \text { [123] }\end{array}$ & $\begin{array}{l}\text { randomized, } \\
\text { placebo- } \\
\text { controlled, } \\
\text { single- } \\
\text { blinded }\end{array}$ & $\begin{array}{l}\text { previous } \\
\text { sporadic } \\
\text { adenoma/6 }\end{array}$ & 702 & 1.5 & 3 & $\mathrm{~T}$ & $\begin{array}{l}- \\
(p=0.08)\end{array}$ \\
\hline $\begin{array}{l}\text { Wargovich, } \\
1992 \text { [123] }\end{array}$ & $\begin{array}{l}\text { randomized, } \\
\text { placebo- } \\
\text { controlled, } \\
\text { single- } \\
\text { blinded }\end{array}$ & $\begin{array}{l}\text { previous } \\
\text { sporadic } \\
\text { adenoma/6 }\end{array}$ & 702 & 2.0 & 1 & $\mathrm{~T}$ & - \\
\hline $\begin{array}{l}\text { Wargovich, } \\
1992 \text { [123] }\end{array}$ & $\begin{array}{l}\text { randomized, } \\
\text { placebo- } \\
\text { controlled, } \\
\text { single- } \\
\text { blinded }\end{array}$ & $\begin{array}{l}\text { sporadic } \\
\text { adenoma/ } 6\end{array}$ & 729 & 2.0 & 1 & $\mathrm{~T}$ & - \\
\hline $\begin{array}{l}\text { Wargovich, } \\
1992 \text { [123] }\end{array}$ & $\begin{array}{l}\text { randomized, } \\
\text { placebo- } \\
\text { controlled, } \\
\text { single-blind }\end{array}$ & $\begin{array}{l}\text { sporadic } \\
\text { adenoma } / 6\end{array}$ & 729 & 2.0 & 1 & $\mathrm{~T}$ & $\begin{array}{l}- \\
(p=0.06)\end{array}$ \\
\hline $\begin{array}{l}\text { Bostick, } \\
1993 \text { [128] }\end{array}$ & $\begin{array}{l}\text { randomized, } \\
\text { double blind, } \\
\text { placebo- } \\
\text { controlled }\end{array}$ & $\begin{array}{l}\text { sporadic } \\
\text { adenoma/21 }\end{array}$ & 951 & 1.2 & 2 & $\mathrm{~T}$ & 0 \\
\hline $\begin{array}{l}\text { Kleibeuker, } \\
1993 \text { [129] }\end{array}$ & uncontrolled & adenoma/17 & $\mathrm{nm}$ & 1.5 & 3 & B & + \\
\hline $\begin{array}{l}\text { Kleibeuker, } \\
1993 \text { [129] }\end{array}$ & uncontrolled & adenoma/7 & $\mathrm{nm}$ & 1.5 & 12 & B & + \\
\hline $\begin{array}{l}\text { O'Sullivan, } \\
1993 \text { [125] }\end{array}$ & uncontrolled & adenoma $/ 20$ & $\mathrm{~nm}$ & $1-2$ & 1 & B & - \\
\hline $\begin{array}{l}\text { Thomas, } \\
1993[126]\end{array}$ & $\begin{array}{l}\text { double blind } \\
\text { placebo- } \\
\text { controlled }\end{array}$ & adenoma/25 & $\mathrm{nm}$ & 1.5 & 6 & $\mathrm{C}$ & - \\
\hline
\end{tabular}

* Calcium carbonate unless otherwise indicated; $\mathrm{T}=$ tritiated thymidine; $\mathrm{B}=5$-bromodeoxyuridine and histochemistry; $\mathrm{C}=$ colonic crypt cell production rate; - = decrease;

$+=$ increase; $0=$ no effect: FAP $=$ Familial Adenomatous Polyposis; $\mathrm{nm}=$ not mentioned. 
Wargovich et al. experimented with different doses of supplementation. ${ }^{123}$ They published two small controlled trials, in which a dose of $1.5 \mathrm{~g}$ /day resulted in an insignificant $20 \%$ decrease in the labelling index, whereas a dose of $2.0 \mathrm{~g} /$ day resulted in a $29 \%$ decrease which was significant.

In a double blinded controlled trial ${ }^{128}$ with calcium supplementation of 1.2 grams a day, the difference between change in the mean Labelling Index from baseline to 8 weeks' follow-up in the placebo group versus the calcium group was not statistically significant. Kleibeuker et al. ${ }^{129}$ report an increase of the labelling index after 3 months as well as one year of supplementation. This is the only study which used biopsies from the mid sigmoid, all other studies used rectal biopsies to determine cell proliferation.

During these past 5 years a considerable number of placebo-controlled trials on calcium and cell proliferation are conducted. The results were not conclusive, however, partially because the techniques used to study cell-proliferation and the preferable end-point studied are still discussed. ${ }^{130}$

Overall, it can be concluded that, despite the research activities on fermented dairy products and calcium as related to colorectal cancer risk, results remain contradictory and our studies still provide a relevant contribution.

\section{References}

1. Harris CC. Chemical and physical carcinogenesis.: advances and perspectives for the 1990 s. Cancer Res 1991;51suppl:5023S-5044S.

2. Hill MJ, Morson BC, Bussey HJ. Aetiology of adenoma-carcinoma sequence in large bowel. Lancet 1978; 1:245-247.

3. Lipkin M. Phase 1 and phase 2 proliferative lesions of colonic epithelial cells in diseases leading to colorectal cancer. Cancer 1974;34:878.

4. Terpstra OT, Van Blankenstein M, Dees J, Eilers GAM. Abnormal pattern of cell proliferation in the entire colonic mucosa of patients with adenoma or cancer. Gastroenterology 1987;92:704-708.

5. Hill MJ. Aetiology of colorectal cancer: current concepts. Baillières Clinical Gastroenterology 1989;3:567-591.

6. Fearon ER and Vogelstein B. A genetic model for colorectal tumorigenesis. Cell 1990;61:759-767.

7. Goelz S, Vogelstein B, Hamilton S, Feinberg A. Hypomethylation of DNA from benign and malignant human colon neoplasms. Science 1985;228:187-190.

8. Giovannucci E, Stampfer MJ, Colditz GA, et al. Folate, methionine, and alcohol intake and risk of colorectal adenoma. J Natl Cancer Inst 1993;85:875-884.

9. Anonymus. Folate, alcohol, methionine and colon cancer risk: is there a unifying theme? Nutr Rev 1994;52:18-28.

10. Bos JL, Fearon ER, Hamilton SR, et al. Prevalence of ras gene mutations in human colorectal cancers. Nature 1987;327:293-297.

11. Barbacid M. Ras genes. Annu Rev Biochem 1987;56:779-827.

12. Baker S, Fearon ER, Nigro JM, et al. Chromosome $17 \mathrm{p}$ deletions and $\mathrm{p} 53$ gene mutations in colorectal carcinomas. Science 1989;244:217-221.

13. Nigro JM, Baker SJ, Preisinger AC, et al. Mutations in the p53 gene occur in diverse human 
tumour types. Nature 1989;342:705-708.

14. Cho KR and Vogelstein B. Genetic alterations in the adenoma-carcinoma sequence. Cancer 1992;1727-1731.

15. Hollstein M, Sidransky D, Vogelstein B, Harris CC. P53 mutations in human cancers. Science 1991;253:49-53.

16. Vogelstein B and Kinzler K. Carcinogens leave fingerprints. Nature 1992;355:209-210.

17. Fearon E, Cho K, Nigro J, et al. Identification of a chromosome $18 \mathrm{q}$ gene that is altered in colorectal cancers. Science 1990;247:49-56.

18. Vogelstein B, Fearob E, Hamilton S, et al. Genetic alterations during colorectal tumor development. N Engl J Med 1988;319;525-532.

19. Doll $R$ and Peto $R$. The causes of cancer. Quantitative estimates of avoidable risks of cancer in the United States today. Oxford Univ. Press, Oxford, 1981.

20. Hill MJ. Microbes and human carcinogenesis. Edward Arnold. London, 1986.

21. Goldin BR, Dwyer J, Gorbach SL, Gordon W, Swenson L. Influence of diet and age on fecal bacterial enzymes. Am J Clin Nutr 1978;31:S136-S140.

22. Rafter JJ, Bakke J, Larsen H, Gustafsson B, Gustafsson J-A. Role of the intestinal microflora in the formation of sulfur-containing conjugates of xenobiotics. Rev Biochem Toxicol $1983 ; 5: 387-408$.

23. Willett WC. The search for the causes of breast and colon cancer. Nature 1989;338:389-394.

24. Bingham SA. Diet and large bowel cancer. J Roy Soc Med 1990;83:420-422.

25. Cummings JH, Wiggins HS, Jenkins DJ, et al. Influence of diets high and low in animal fat on bowel habit, gastro-intestinal transit time, faecal microflora, bile acid and fat excretion. $J$ Clin Invest 1978;61:953-963.

26. Reddy BS, Watanabe K, Weisburger JH, Wynder EL. Promoting effect of bile acids in colon carcinogenesis in germfree and conventional F344 rats. Cancer Res 1977;37:3238-3242.

27. Deschner EE, Cohen BI, Raicht RF, et al. Acute and chronic effect of dietary cholic acid on colonic epithelial cell proliferation. Digestion 1981;21:290-296.

28. Bull AW, Soullier BK, Wislon PS, Hayden MT, Nigro ND. Promotion of azoxymethaneinduced intestinal cancer by high-fat dict in rats. Cancer Res 1979;39:4959-4965.

29. Lapré JA, Termont DSML, Groen AK, Van der Meer R. Lytic effects of mixed micelles of fatty acids and bile acids. Am J Physiol 1992;263:G333-G337.

30. Hill MJ. The role of colon anaerobes in the metabolism of bile acids and steroids and its relation to colon cancer. Cancer 1975;36:2387-2400.

31. Morotomi M, Guillem JG, Logefro $\mathrm{P}$, Weinstein IB. Production of diacylglycerol, an activator of protein kinase $C_{3}$ by human intestinal microflora. Cancer Res 1991;50:3595-3599.

32. Stephen $\mathbf{A}$ and Cummings J. Mechanisms of action of dietary fihut in the human colon. Nature 1980;284:283-284.

33. Cummings $\mathrm{JH}$. Fermentation in the human large intestine: evidence and implications for health. Lancet 1983;1:1206-1209.

34. Steinmetz KA and Potter JD. Vegetables, fruit, and cancer. II. Mechanisms. Cancer Causes Control 1991;2:427-442.

35. Block G, Patterson B, Subar A. Fruit, vegetables, and cancer prevention: a review of the epidemiological evidence. Nutr Cancer 1992;18:1-29.

36. Steinmetz KA and Potter JD. Vegetables, fruit, and cancer. I. Epidemiology. Cancer Causes Control 1991;2:325-357.

37. Howe GR, Beniti E, Castellato R, et al. Dietary intake of fiber and decreased risk of cancers of the colon and rectum: evidence from the combined analysis of 13 case-control studies. J Natl Cancer Inst 1984;72:1323-1325.

38. Sigimura $T$ and Sato $S$. Mutagens-carcinogens in foods. Cancer Res $1983 ; 43($ suppl):2415s2421s.

39. Corpet D, Stamp D, Medline A, Minkin S, Archer MC, Bruce WR. Promotion of colonic microadenoma growth in mice and rats fed cooked sugar or cooked casein and fat. Cancer Res 1990;50:6955-6958. 
40. Potter JD, Slattery ML, Bostick RM, Gapstur SM. Colon cancer: a review of the epidemiology. Epidemiol Rev 1993;15:499-545.

41. Holdstock DJ, Misiewicz JJ, Smith T, et al. Propulsion (mass movement) in the human colon and its relationship to meals and somatic activity. Gut 1970;11:91-99.

42. Thronton J, Symes C, Heaton K. Moderate alcohol intake reduces bile cholesterol saturation and raises HDL cholesterol. Lancet 1983;ii:819.

43. Longnecker MP, Orza MJ, Adams ME, Vioque J, Chalmers TC. A meta-analysis of alcoholic beverage consumption in relation to risk of colorectal cancer. Cancer Causes Control 1990;1:59-69.

44. Heath CW. Rheumatoid arthritis, aspirin, and gastrointestinal cancer. J Natl Cancer Inst 1993;85:258-259.

45. Giovannucci E, Colditz GA, Stampfer MJ. A meta-analysis of cholecystectomy and risk of colorectal cancer. Gastroenterology 1993;105:130-141.

46. Jacobsen BK and Thelle DS. Coffee, cholesterol and cancer incidence: is there a link? Brit Med J 1986;294:4-5.

47. Rosenberg L. Coffee and tea consumption in relation to the risk of large bowel cancer: a review of epidemiologic studies. Cancer Lett 1990;52:163-171.

48. Giovannucci E, Colditz GA, Stampfer MJ, et al. A prospective study of cigarette smoking and risk of colorectal adenoma and colorectal cancer in United States women. J Natl Cancer Inst 1994;86:192-199.

49. Giovannucci E, Rimm EB, Stampfer MJ, et al. A prospective study of cigarette smoking and risk of colorectal adenoma and colorectal cancer in United States men. J Natl Cancer Inst 1994;86:183-191.

50. DeCosse JJ, Ngoi SS, Jacobson JS, Cennerazzo WJ. Gender and colorectal cancer. Eur J Cancer Prev 1993;2:105-115.

51. Potter JD and McMichael AJ. Reproduction, endogeneous and exogeneous sex hormones and colon cancer: a review and hypothesis. J Natl Cancer Inst 1980;65:1201.

52. Lampe JW, Fredstrom SB, Slavin JL, Potter JD. Sex differences in colonic function: a randomized trial. Gut 1993;34:531-536.

53. Goldin BR and Gorbach SL. The effect of milk and lactobacillus feeding on human intestinal bacterial enzyme activity. Am J Clin Nutr 1984;39:756-761.

54. Newmark HL, Wargovich MJ, Bruce WR. Colon cancer and dietary fat, phosphate, and calcium: a hypothesis. J Natl Cancer Inst 1984;72:1323-1325.

55. Alder RJ and McKeown-Eyssen G. Calcium intake and risk of colorectal cancer. Front Gastrointest Res 1988;14:177-187.

56. McKeown-Eyssen GE and Bright-See E. Dietary factors in colon cancer: international relationships. An update. Nutr Cancer 1985;7:251-253.

57. McKeown-Eyssen GE and Bright-See E. Dietary factors in colon cancer: international relationships. Nutr Cancer 1984;6:160-170.

58. International Agency for Research on Cancer, Intestinal Microbiology Group. Dietary fiber, transit time, faecal bacteria, steroids and colon cancer in no Scandinavian populations. Lancet 1977;2:207-211.

59. Jensen OM, MacLennan R, Wahrendorf $J$ on behalf of the IARC Large Bowel Group. Diet, bowel function, fecal characteristics, and large bowel cancer in Denmark and Finland. Nutr Cancer 1982;4:5-19.

60. Benno Y, Suzuki K, Suzuki K, Narisawa K, Bruce WR, Mitsuoka T. Comparison of the fecal microflora in rural Japanese and urban Canadians. Microbiol Immunol 1986;30:521532.

61. International Study Group of Fermented Fresh Milk Product Research. The production of fermented milk in the world. IDF-bulletin 1984;179:8-15.

62. World Health Organization, International Agency for Research on Cancer and International Association of Cancer Registries. Age-standardized and cumulative (0-64,0-74) incidence rates by sites. In: Muir C, Waterhouse J, Mack T, Powell J. Whelan S, ed. Cancer Incidence in five continents. Volume V. Lyon: IARC scientific publications no. $88,1987: 852-853$. 
63. Sorenson AW, Slattery ML, Ford MH. Calcium and colon cancer: a review. Nutr Cancer 1988;11:135-145.

64. Rothman KJ. Modern Epidemiology. 1st ed. Little Brown \& Co. Boston/Toronto, 1986.

65. Young TB and Wolf DA. Case-control study of proximal and distal colon cancer and diet in Wisconsin. Int J Cancer 1988;42:167-175.

66. Tajima $\mathrm{K}$ and Tominaga S. Dietary habits and gastro-intestinal cancers: a comparative casecontrol study of stomach and large intestinal cancers in Nogoya, Japan. Jpn J Cancer Res 1985;76:705-716.

67. Macquart-Moulin G, Riboli A, Cornée J, Charnay B, Berthezène P, Day N. Case-control study on colorectal cancer and diet in Marseilles. Int J Cancer 1986;38:183-191.

68. Macquart-Moulin G, Riboli E, Cornée J, Kaaks R, Berthezène P. Colorectal polyps and diet: a case-control study in Marseilles. Int J Cancer 1987;40:179-188.

69. Tuyns AJ, Kaaks R, Haelterman M. Colorectal cancer and the consumption of foods: a casecontrol study in Belgium. Nutr Cancer 1988;11:189-204.

70. Slattery ML, Sorenson AW, Ford MH. Dietary calcium intake as a mitigating factor in colon cancer. Am J Epidemiol 1988;128:504-514.

71. Kune S, Kune GA, Watson IF. Case-control study of dietary etiological factors: The Melbourne colorectal cancer study. Nutr Cancer 1987;9:21-42.

72. PickJe LN, Greene MH, Ziegler RG, et al. Colorectal cancer in rural Nebraska. Cancer Res 1984;44:363-369.

73. Manousos O, Day NE. Trichopoulos D, Gerovassilis F, Tzonou A, Polychronopoulou A. Diet and colorectal cancer: a case-control study in Greece. Int J Cancer 1983;32:1-5.

74. Graham S, Marshall J, Haughey B, et al. Dietary epidemiolngy uf cancer of the colon in western New York. Am J Epidemiol 1998:128:490-5()3.

75. Lee HP, Gourley L, Duffy SW, Estève J, Lec J, Day NE. Colorectal cancer and diet in an Asian population-a case-control study among Singapore Chinesc. Int J Cancer 1989:43:10071016.

76. Miller AB, Howe GR, Jain M, Craib KJP, Harrison L. Food items and food groups as risk factors in a case-control study of diet and colorectal cancer. Int J Cancer 1983;32:155-161.

77. Tuyns AJ, Haelterman M, Kaaks R. Colorectal cancer and the intake of nutrients: oligosaccharides are a risk factor, fats are not: a case-control study in Belgium. Nutr Cancer 1987; 10:181-196.

78. Phillips RL and Snowdon DA. Dietary relationship with fatal colorectal cancer among Seventh-day Adventists. J Natl Cancer Inst 1985;74:307-317.

79. Garland CF, Shekelle RB, Barrett-Connor E, Criqui MH, Rossof AH, Paul O. Dictary calcium and vitamin D and risk of colorectal cancer: a 19-year prospective study in men. Lancet 1985; 1:307-309.

80. Heilbrun LK, Hankin JH, Nomura A, Stemmermann GN. Colon cancer and dietary fat, phosphorus, and calcium in Hawaiian-Japanese men. Am J Clin Nutr 1986;43:306-309.

81. Wu AH, Paganini-Hill A, Ross RK, Henderson BE. Alcohol, physical activity and other risk factors for colorectal cancer: a prospective study. Brit J Cancer 1987;55:687-694.

82. Peters RK, Pike MC, Garabrant D, Mack TM. Diet and colon cancer in Los Angeles County, California. Cancer Causes Control 1992;3:457-473.

83. Negri E, La Vecchia C, D’Avanzo B, Franceschi S. Calcium, dairy products and colorectal cancer. Nutr Cancer 1990;13:255-262.

84. Bidoli E, Franceschi S, Talamini R, Barra S, La Vecchia C. Food consumption and cancer of the colon and rectum in North-Eastern Italy. Int J Cancer 1992;50:223-229.

85. Whitemore AS, Wu-Williams AH, Lee $\mathrm{M}$, et al. Diet, physical activity, and colorectal cancer among Chinese in North America and China. J Natl Cancer Inst 1990;82:915-926.

86. Zaridze D, Filipchenko V, Kustov V, Serdyuk V, Duffy S. Diet and colorectal cancer: results of two case-control studies in Russia. Eur J Cancer 1993;29A:112-115.

87. Meyer $\mathrm{F}$ and White $\mathrm{E}$. Alcohol and nutrients in relation to colon cancer in middle-aged adults. Am J Epidemiol 1993;138:225-236.

88. Iscovich JM, L'Abbé KA, Castelleto R, et al. Colon cancer in Argentina. 1: risk from intake 
of dietary items. Int J Cancer 1992;51:851-857.

89. Steinmetz KA and Potter JD. Food group consumption and colon cancer in the Adelaide case-control study. II. Meat, poultry, seafood, dairy foods and eggs. Int J Cancer 1993;53:720-727.

90. Benito E, Obrador A, Stiggelbout A, et al. A population-based case-control study of colorectal cancer in Majorca. I. Dietary factors. Int J Cancer 1990;45:69-76.

91. Benito E, Stiggelbout A, Bosch FX, et al. Nutritional facturs in colorectal cancer risk: a case-control study in Majorca. Int J Cancer 1991;49:161-167.

92. Kune GA, Kune S, Read A, Macgowan K, Penfold C, Watson LF. Colorectal polyps, diet, alcohol, and family history of colorectal cancer: a case-control study. Nutr Cancer 1991;16:25-30.

93. Benito E, Cabeza E, Moreno V, Obrador A, Bosch FX. Dict and colorectal adenomas: a case-control study in Majorca. Int J Cancer 1993;55:213-219.

94. Stemmermann GN, Nomura A, Chyou PH. The influence of dairy and nondairy calcium on subsite large bowel cancer risk. Dis Colon Rectum 1990;33:190-194.

95. Ursin G, Bjelke E, Heuch I, Vollset SE. Milk consumption and cancer incidence: a Norwegian prospective study. Brit J Cancer 1990;61:454-459.

96. Bostick RM, Potter JD, Sellers TA, McKenzie DR, Kushi LH, Folsom AR. Relation of calcium, vitamin $\mathrm{D}$, and dairy food intake to incidence of colon cancer among older women. The lowa Women's Health Study. Am J Epidemiol 1993;137:1302-1317.

97. Lidbeck A, Nord CE, Gustafsson J-A, Rafter J. Lactobacilli, anticarcinogenic activities and human intestinal microflora. Eur J Cancer Prev 1992;1:341-353.

98. Reddy GV, Friend BA, Shahani KM, Farmer RE. Antitumor activity of yogurt components. J Food Prot 1983:46:8-11.

99. Goldin BR and Gorbach SL. Effect of lactobacillus acidophilus dietary supplements on 1,2 dimethylhydrazine dihydrochloride-induced intestinal cancer in rats. J Natl Cancer Inst 1980;64:263-265.

100. Marteau P, Pochart P, Flourié B, et al. Effects of chronic ingestion of a fermented dairy product containing lactobacillus acidophilus and bifidobacterium bifidum on metabolic activities of the colonic flora in humans. Am J Clin Nutr 1990:52:68.5-688.

101. Gilliland SE. Properties of yoghurt. Therapeutic properties of fermented milks. In: Robinson RK, ed. Therapeutic effects of yoghurt. Essex, England: Elseviers Science Publishers LTD, 1991:65-80.

102. Perdigon G, Alvares S, Nader de Macias ME, Margni RA, Oliver G, Pesce de Ruiz Holgado AA. Lactobacilli administered orally induce release of enzymes from peritoneal macrophages in mice. Milchwissenschaft 1986;41:344-348.

103. De Simone C, Bianchi Salvadori B, Negri R, Ferrazzi M, Baldinelli L, Vesely R. The adjuvant effect of yogurt on production of gamma-interferon by con A-stimulated human peripheral blood lymphocytes. Nutr Rep Int 1986;33:419-433.

104. Zhang $\mathrm{XB}$ and Ohta $\mathrm{Y}$. In vitro binding of mutagenic pyrolyzates to lactic acid bacterial cells in human gastric juice. J Dairy Sci 1991;74:752-757.

105. Lidbeck A, Overvik E, Rafter J, Nord CE, Gustafsson J-A. Effect of Lactobacillus acidophilus supplements on mutagen excretion in faeces and urine in humans. Microb Ecol Hith Dis 1992;5:59-67.

106. Robins-Brown RM and Levine MM. The fate of ingested lactobacilli in the proximal small intestine. Am J Clin Nutr 1981;34:514-519.

107. Lidbeck A, Gustafsson J-A, Nord CE. Impact of laclobacillus acidophilus supplements on the human oropharyngeal and intestinal microflora. Scand J Infect Dis 1987;19:531-537.

108. Lidbeck A, Edlund C, Gustafsson J-A, Kager L, Nord CE. Impact of lactobacillus acidophilius on the normal intestinal microflora after administration of two antimicrobial agents. Infection 1988; 16:329-336.

109. Wargovich MJ, Eng VWS, Newmark HL, Bruce WR. Calcium amcliorates the toxic effect of deoxycholic acid on colonic epithelium. Carcinogenesis 1983:4:1205-1207.

110. van der Meer R, Termont DSML, De Vries HT. Differential effects of calcium ions and 
calcium phosphate on cytotoxicity of bile acids. Am J Physiol 1991;260:G142-G147.

111. Skraastad $O$ and Reicheit KL. An endogenous colon mitosis inhibitor and dictary calcium inhibit the increased colonic cell proliferation induced by cholic acid. Scan J Gastroenterol 1988:23:801-807.

112. Wargovich MJ, Eng VWS, Newmark HL, Bruce WR. Calcium inhibits the damaging and compensatory proliferative effects of fatty acids on mouse colon epithelium. Cancer Letters 1984;23:253-258.

113. Lipkin $M$ and Newmark $H$. Effect of added dietary calcium on colonic epithelial-cell proliferation in subjects of high risk for familial colonic cancer. $N$ Engl $\mathfrak{J}$ Med $1985 ; 313 ; 1381-1384$.

114. Buset $M$, Lipkin $M$, Winawer $S$, Swaroop $S$, Friedman E. Inhibition of human colonic epithelial cell proliferation in vivo and in vitro by calcium. Cancer Res 1986;46:5426-5430.

115. Buset $\mathrm{M}$, Lipkin $\mathrm{M}$, Winawer $\mathrm{S}$, Friedman $\mathrm{E}$. Direct and indirect protection of human colonic epithelial cells by calcium. Gastroenterology 1987;92:1334.

116. Lipkin M, Friedman E, Winawer SJ, Newmark HL. Colonic epithelial cell proliferation in responders and non-responders to supplemental dietary calcium. Cancer Res 1989;49:248254.

117. Appleton GVN, Davies PW, Bristol JB, Williamson RCN. Inhibition of intestinal carcinogenesis by dietary supplementation with calcium. Brit J Surg 1987;74:523-525.

118. Wargovich MJ, Allnutt D, Palmer C, Anaya P, Stephens LC. Inhibition of the promotional phase of azoxymethane-induced colon carcinogenesis in the F344 rat by calcium lactate: effect of simulating two human nutrient density levels. Cancer Lett 1990;53:17-25.

119. Sitrin MD, Halline AG, Abrahams C, Brasitus TA. Dietary calcium and vitamin D modulate 1.2-dimethylhydrazine-induced colonic carcinogenesis in the rat. Cancer Res 1991;51:56085613.

120. Llor X, Jacoby RF, Teng BB, Davidson NO, Sitrin MD, Brasitus TA. K-ras mutations in 1,2-Dimethylhydrazine-induced colonic tumors: effects of supplemental dietary calcium and vitamin D deficiency. Cancer Res 1991;51:4305-4309.

121. Rozen P, Fireman Z, Fine N, Wax Y, Ron E. Oral calcium suppresses increased rectal epithelial proliferation of persons at risk of colorectal cancer. Gut 1989;30:650-655.

122. Gregoire RC, Stern HS, Yeung KS, et al. Effect of calcium supplementation on mucosal cell proliferation in high risk patients for colon cancer. Gut 1989;30:376-382.

123. Wargovich MJ, Isbell G, Shabot M, et al. Calcium supplemention decreases reclal epithelial cell proliferation in subjects with sporadic adenoma. Gastroenterology 1992;103:92-97.

124. Barsoum $\mathrm{GH}$, Hendrickse $\mathrm{C}$, Winslet $\mathrm{MC}$, et al. Reduction of mucosal crypt cell proliferation in patients with colorectal adenomatous polyps by dietary calcium supplementation. Brit J Surg 1992;79:581-583.

125. O'Sullivan KR, Mathias PM, Beattle S, O'Morain C. Effect of oral calcium supplementation on colonic crypt cell proliferation in patients with adenomatous polyps of the large bowel. Eur J Gastroenterol Hepatol 1993;5:85-89.

126. Thomas MG, Thomson JPS, Williamson RCN. Oral calcium inhibits rectal epithelial proliferation in familial adenomatous polyposis. Brit J Surg 1993;80:499-501.

127. Stern HS, Gregoire RC, Kashtan H, Stadler J, Bruce RW. Long-term effects of dietary calcium on risk markers for colon cancer in patients with familial polyposis. Surgery 1990; 108:528-533.

128. Bostick RM, Potter JD, Fosdick L, et al. Calcium and colorectal epithelial cell proliferation: a preliminary randomized, double-blinded, placebo-controlled clinical trial. J Natl Cancer Inst 1993;85:132-141.

129. Kleibeuker JH, Welberg JWM, Mulder $\mathrm{NH}$, et al. Epithelial cell proliferation in the sigmoid colon of patients with adenomatous polyps increases during oral calcium supplementation. Brit J Cancer 1993;67:500-503.

130. Zimmerman J. Does dietary calcium supplementation reduce the risk of colon cancer? Nutr Rev 1993;51:109-112.

131. Willett WC, Stampfer MJ, Colditz GA, Rosner BA, Speizer FE. Relation of meat, fat, and 
fiber intake to the risk of colon cancer in a prospective study among women. N Engl J Med 1990):323:1664-1672.

132. Aycbo AD, Angelo IA, Shahani KM. Effect of ingesting Lactobacillus acidophilus milk upon fecal flora and enzyme activity in humans. Milchwissenschaft 1980:35:730-733.

133. Lidbeck A, Gletner Allinger U, et al. Impact of Lactobacillus acidophilus supplements on the faccal microflora and soluble faecal bile acids in colon cancer patients. Microb Ecol Hlth Dis 1991;4:81-88. 


\section{Chapter 3}

Calcium, vitamin D, dairy foods and the occurrence of colorectal adenomas among men and women in two prospective studies

Ellen Kampman, Edward Giovannucci, Pieter van 't Veer, Eric Rimm, Meir J. Stampfer, Graham A. Colditz, Frans J. Kok, Walter C. Willett. American Journal of Epidemiology $1994 ; 139: 16-29$ 


\section{Abstract}

A high intake of calcium, vitamin D or specific dairy products is thought to reduce the incidence of colorectal cancer. The association of these nutrients and foods with the occurrence of colorectal adenomas, precursors of cancer, was studied in two large US cohort studies.

Cases were patients with a diagnosis of adenomatous polyps of the left colon or rectum (331 men, 1986-1990; 350 women, 1980-1988) controls were persons with endoscopic findings negative for adenoma ( 9,159 men and 8,585 women).

After adjustment for age, total energy, family history of colorectal cancer, body mass index, alcohol consumption, folate, intake of saturated fat and fiber, indications for endoscopy, and previous endoscopy, total calcium intake was not associated with adenoma (relative risk (RR), highest versus lowest quintile of intake: men, 1.13, 95\% confidence interval (CI) 0.76-1.66; women, $1.17,95 \% \mathrm{CI}=0.81-1.69$ ).

Total vitamin $D$ intake was unrelated to the risk for adenoma in men $(R R=1.29$, $95 \% \mathrm{CI}=0.87-1.93$ ). An inverse nonsignificant association was observed in women in the $1980-1988$ analyses $(\mathrm{RR}=0.68,95 \% \mathrm{CI}=0.41-1.13$, trend $\mathrm{p}=0.09$ ), mainly attributable to the intake of multivitamin supplements, but an analysis of 4-year data (1984-1988) using a more detailed dietary assessment showed no association with vitamin $\mathrm{D}(\mathrm{RR}=1.04,95 \% \mathrm{CI}=0.65-1.67)$.

Milk consumption and intake of total fermented dairy products were not related to adenoma risk.

In conclusion, the occurrence of colorectal adenoma was neither related to calcium intake nor to milk consumption, whereas vitamin D from supplements but not diet was slightly, but not significantly, inversely associated with risk among women only. 


\section{Introduction}

It has been hypothesized that diets high in fat and low in dietary fiber increase the risk for colon cancer. ${ }^{1}$ An increased risk has also been attributed to the consumption of red meat ${ }^{1,2}$ and a decreased risk to the consumption of vegetables and fruits. ${ }^{3}$ An additional hypothesis suggests a protective effect of calcium or the consumption of calcium-rich milk products. ${ }^{4}$ Support for this relation derives from clinical and experimental studies $^{5.7}$ and from ecological data on colorectal cancer. ${ }^{8-10}$ It has been hypothesized that calcium reduces the risk for colon cancer by forming insoluble soaps with ionized fatty acids and secondary bile acids in the colon lumen, potentially diminishing the proliferative stimulus of these substances on the colon mucosa. ${ }^{5,6} \mathrm{~A}$ direct effect of calcium on the proliferative activity of the mucosa has also been suggested. ${ }^{7}$ However, case-control and cohort studies of colorectal cancer are not conclusive; some studies observed an inverse association with calcium or milk consumption, ${ }^{11 \cdot 13}$ while others suggested only a slight non-significant association ${ }^{14,15}$ or no relation. ${ }^{16-18}$

Other nutrients or products associated with calcium intake may also be important. For instance, a high phosphate/calcium ratio in the diet may modify the possible inverse association with calcium. ${ }^{5}$ Epidemiologic $^{19.24}$ and experimental studies ${ }^{21-23}$ suggest a distinct protective mechanism of vitamin $D$ that possibly involves cell proliferation. Furthermore, apart from the calcium and vitamin D content of milk, a protective effect against tumor development has been suggested for fermented dairy products, ${ }^{24-28}$ which contain micro-organisms that may influence the normal colonic flora $^{29.31}$ or activate the immune system. ${ }^{32,33}$ Although in physiologic studies, only specific strains of viable microorganisms seem to influence tumor occurrence or growth, ${ }^{34}$ recent epidemiologic studies in the United States suggest an inverse association between the consumption of yogurt and cheese and colon cancer. ${ }^{35,36}$

An effect of calcium or vitamin $D$ on cell proliferation or an altered bacterial metabolism of fermented milk products may be particularly important for the early stages of tumor development represented by the formation and growth of colorectal polyps. Previous studies considering the association between calcium or milk consumption and colorectal polyps ${ }^{37-39}$ have been limited by retrospective diet assessment. To our knowledge, no studies on colorectal adenomas have addressed the intake of vitamin D or fermented milk products other than cheese.

To study prospectively the associations of the intake of calcium, vitamin $\mathrm{D}$ and dairy products with the occurrence of colorectal adenoma in men and women, we used data from two large US cohort studies: the Health Professionals Follow-Up Study (HPFS) and the Nurses' Health Study (NHS). The associations of saturated fat, dietary fiber, 
meat, vegetables and fruits with the risk for colorectal adenoma in the HPFS has been described previously. ${ }^{40}$

\section{Materials and methods}

\section{Study Cohorts}

In 1986, the HPFS enrolled 51,529 male dentists, pharmacists, optometrists, osteopaths, podiatrists, and veterinarians, aged 40 to 75 years. In 1976, the NHS enrolled 121,700 female registered nurses, aged 30-55 years. Detailed dietary intake data were collected in 1980 and 1984 in the NHS and in 1986 in the HPFS, by means of a mailed semiquantitative food frequency questionnaire. Each biennial follow-up questionnaire contains items on date of birth (to confirm identity) and current weight, height and tobacco use. Family history of colon or rectal cancer, professionally diagnosed medical conditions, screening activities, medications and physical activity are updated periodically. Up to 1990 , more than $96 \%$ of the subjects had responded to follow-up questionnaires mailed to the entire cohort. ${ }^{41}$ Both cohorts are described in more detail in earlier publications. ${ }^{42,43}$

\section{Dietary assessment}

In 1980, the NHS semi-quantitative food-frequency questionnaire included 61 food items, and the 1984 questionnaire was increased in length to 121 items. The questionnaire used in the HPFS in 1986 included 131 foods. Multivitamin use (dose, frequency, brand and duration) was also assessed. In each questionnaire, participants were asked how often on average they consumed a specified commonly used portion size of each food during the past year. There were nine possible responses, ranging from almost never or less then once per month up to six or more times per day. In 1980, the questionnaire included seven specific dairy foods: skim or low fat milk, whole milk, ice cream, yogurt, cottage cheese, hard cheese and butter. The 1984 and 1986 questionnaires included these seven items and four more: cream, sour cream, sherbet or ice-milk and cream cheese.

Nutrient intakes were computed as the frequency of intake multiplied by the nutrient composition $^{44,45}$ of the specific portion size, and are computed with and without vitamin and mineral supplements. Analyses were conducted with energy-adjusted nutrient intakes based on residuals from the regression of nutrient intake on total caloric intake. $^{* 6}$

Evaluations of the reproducibility and validity of the 1980, 1984 and 1986 versions of the food frequency questionnaire indicated that this questionnaire provides useful information about intake of a wide variety of nutrients and foods consumed over an 
extended period. ${ }^{47-51}$ The intraclass correlation coefficients for calcium intake assessed by questionnaires 1 year apart, using the 1986 HPFS version, was 0.64 for total calcium and 0.70 for calcium without supplements. ${ }^{517}$ Correlation coefficients between the energy-adjusted calcium intakes measured by diet records and by the second questionnaire were 0.53 for calcium with and without supplements. ${ }^{50}$ At the time of the validation studies, diet record values for vitamin $D$ were not available. However, the major dietary sources of vitamin D (dairy products, especially low-fat or skim milk) were measured reasonably well. Pearson correlation coefficients between the second questionnaire and the average of the two 1-week diet records for dairy foods were 0.70 in men $^{51}$ and 0.79 for low fat or skim milk consumption in women. ${ }^{49}$

\section{Study population}

Subjects with no history of colorectal polyps, cancer (except nonmelanoma skin cancer), polyposis coli or ulcerative colitis at the beginning of the follow-up period were eligible for analysis (HPFS: 47,037 men; NHS: 88,396 women). All individuals with implausible total caloric intake (outside the range of 800-4,200 kcal for men and $600-3,500 \mathrm{kcal}$ for women) or with whole sections of the baseline questionnaire left blank were excluded. The vast majority of polyps were diagnosed in individuals who had endoscopy either for routine screening or for symptoms unrelated to the polyps. Thus, to minimize detection bias, we restricted data analysis to men and women who, in the 1990 questionnaire, reported having undergone a sigmoidoscopy or colonoscopy within the follow-up period (HPFS 1986-1990: 9,490 men; NHS 1980-1988: 8,925 women). ${ }^{52}$ Since only adenomatous polyps are considered precursors of cancer, subjects with hyperplastic polyps were excluded from the analyses. Because most of the endoscopic procedures were sigmoidoscopies, which are essentially limited to the rectum and distal colon (sigmoid and descending colon), only cases with polyps at these sites are included in the analysis.

Of the men reporting an endoscopy in the 1990 HPFS questionnaire, 825 reported one or more newly diagnosed colorectal polyps during the 1986-1990 follow-up period. Of these men 784 (95\%) were contacted, of which $666(85 \%)$ confirmed they had a polyp and gave permission for review of medical records. Histopathologic reports were available for 640 men (96\%), resulting in confirmation of 589 cases of colorectal polyps (adenomatous plus hyperplastic) after 4 years of follow-up. The 51 unconfirmed cases included inflammatory nodules, ulcerative colitis, hemorrhoids, or undiagnostic tissue. After proximal colon adenomas and hyperplastic polyps were excluded, 331 male cases remained for analysis.

Among the women in the NHS who underwent an endoscopy, 724 reported one or more newly diagnosed polyps of the colon or rectum between 1980 and 1988. Of those 
women, $659(9.1 \%)$ were contacted, of which $593(90 \%)$ confirmed they had a polyp and gave permission for review of medical records. After 8 years of follow-up, 509 colorectal polyp cases were confirmed, 350 being adenomatous polyps of the distal colon or rectum.

In total, the 4-year follow-up analyses of the HPFS included 9,490 men (251 with adenomas of the descending/sigmoid colon, 80 with rectal adenoma and 9,159 noncases or controls). The 8-year follow-up in the NHS, included 8,935 women (224 with adenomas of the descending/ sigmoid colon, 126 with rectal adenomas, and 8,585 controls).

Because the 1984 questionnaire provided more detailed information, for some analyses we also assessed the occurrence of polyps in women between 1984 and 1988, using the 1984 questionnaire as the baseline. The 1984-1988 analyses included 7,271 women (180 with adenomas of the descending/sigmoid colon and 103 with rectal adenomas). Most of the subjects in the 1984-1988 follow-up were also in the 19801988 follow-up (99\%), the exceptions being the small number of women who completed a valid food-frequency questionnaire in 1984 but not in 1980 .

\section{Data analysis}

The nutrients of interest were analyzed using quintiles of intake, according to the distribution in the studied population. Calcium and vitamin D intake were considered with and without the intake of supplements, and from both dairy and non-dairy origin. The prevalence rate ratio, based on the prevalence of polyps detected at endoscopy, was used to calculate the relative risk. Relative risks (RR) were calculated using the lowest quintile of intake as the reference and $95 \%$ confidence intervals were calculated between the high and low quintiles. We tested for overall trends by using the median of each quintile of calcium or vitamin $\mathrm{D}$ intake as a continuous variable.

The consumption of individual dairy products was studied by grouping the foods into four or five frequency categories, based on the distribution of intake of the product in the population at large. Relative risks and $95 \%$ confidence intervals were calculated comparing participants who consumed a particular food with those who reported a frequency of less than once a month. We tested for trend by modeling the reported frequencics as a continuous variable.

The consumption of fermented milk products combined was studied using quintiles of the summed frequencies of consumption of each product (yogurt, cottage cheese, hard cheese, sour cream) weighed by the standard portion sizes or calcium content.

To control for several potentially confounding and modifying variables simultaneously, we used multiple logistic regression models including age (in seven categories), total energy intake, history of colon cancer in either parent, indication for 
endoscopy, endoscopies before the study period, body mass index (in quintiles), smoking (never, past, current), physical activity and quintiles of intake of saturated fat, dietary fiber, alcohol, and folate. Since the time of polyp occurrence is not known and the outcome is the prevalence of polyps at endoscopy, we used logistic regression analysis instead of a prospective approach. Because the study population was selected by endoscopy, we adjusted for indication of endoscopy. To study the possible effect modification of the intake of saturated fat, vitamin $\mathrm{D}$ and phosphorus, we assessed the association with calcium (in tertiles) within tertiles (low, medium, high) of these nutrients. A high phosphorus intake relative to the intake of calcium was evaluated using quintiles of the calcium/phosphorus ratio with the lowest quintile as the reference. Similar analyses were conducted separately for cases with left colon and rectal polyps and for cases with small $(<1 \mathrm{~cm})$ and larger $(z 1 \mathrm{~cm})$ polyps. When there was more than one polyp, the size of the largest was considered.

\section{Results}

\section{Population characteristics}

Table 3.1 presents the characteristics of the male and female study population and the prevalence of possible risk factors for colorectal adenoma, according to intake of calcium and vitamin D. Men and women with the highest intake of calcium or vitamin D tended to be a little older at endoscopy, had higher intakes of dietary fiber, protein and phosphorus, a lower intake of alcohol, and smoked less. Men and women in the highest quintiles of calcium and vitamin $\mathrm{D}$ intake more often reported having undergone an endoscopy before the study period than persons with the lowest intake. About $26 \%$ of the male and $16 \%$ of the female cases (34\% of the 1984-1988 follow-up population) had undergone an endoscopy before the study period with negative findings, and are defined here as 'incident' cases. For these cases, the risk for positive findings at endoscopy within the study period was lower and dietary intake was measured closer to the onset of disease than among those who had not previously undergone endoscopy. As no important differences between incident and prevalent cases were seen in inlake of calcium, vitamin D, and dairy products or in other variables of interest, both incident and prevalent cases were included in the analysis.

The occurrence of adenomatous polyps increased with age, and a history of colon or rectal cancer in either parent was positively related to the risk for developing an adenoma. Total energy intake was not associated with risk for adenoma. All subsequent analyses included age, total energy intake and family history of colorectal cancer. 
Table 3.1 Characteristics of the male and female study population, by the lowest and highest quintiles of calcium and vitamin D intake: The Health Professionals Follow-up Study (HPFS) and The Nurses' Health Study (NHS).

\begin{tabular}{|c|c|c|c|c|c|c|c|c|c|c|c|c|}
\hline & \multicolumn{4}{|c|}{ HPFS, $1986-1990$} & \multicolumn{4}{|c|}{ NHS. $1984-1.988$} & \multicolumn{4}{|c|}{ NHS, $1980-1988$} \\
\hline & \multicolumn{2}{|c|}{ calcium } & \multicolumn{2}{|c|}{ vitamin D } & \multicolumn{2}{|c|}{ calcium } & \multicolumn{2}{|c|}{ vitamin D } & \multicolumn{2}{|c|}{ calcium } & \multicolumn{2}{|c|}{ vitamin D } \\
\hline & $Q 1^{\dagger}$ & $\mathrm{QS}^{\mathrm{t}}$ & Q1 & Q5 & Q1 & Q5 & Q1 & Q5 & Q1 & Q5 & Q1 & Q5 \\
\hline Participants (no.) & 1,897 & 1.898 & 1,898 & 1,898 & 1,454 & 1,454 & 1,455 & 1,456 & 1,787 & 1,784 & 1,785 & 1,787 \\
\hline Cases (\%) & 3.1 & 3.0 & 3.9 & 4.0 & 3.8 & 4.1 & 4.1 & 4.1 & 3.7 & 3.6 & 4.6 & 3.0 \\
\hline $\begin{array}{l}\text { Mean age at endoscopy } \\
\text { (years) }\end{array}$ & 57.8 & 59.2 & 56.3 & 59.9 & 54.7 & 56.7 & 54.3 & 56.8 & 54.7 & 55.7 & 54.6 & 55.5 \\
\hline $\begin{array}{l}\text { Mean total energy intake } \\
\text { (kcal) }\end{array}$ & 1,877 & 1,915 & 1,866 & 1,778 & 1,640 & 1,643 & 1,690 & 1,569 & 1,585 & 1,582 & 1,520 & 1,417 \\
\hline $\begin{array}{l}\text { Mean intake } / \text { day of } \\
\text { calcium }(\mathrm{mg}) \\
\text { vitamin D (IU) }\end{array}$ & $\begin{array}{l}547 \\
285\end{array}$ & $\begin{array}{c}1,649 \\
653\end{array}$ & $\begin{array}{l}707 \\
118\end{array}$ & $\begin{array}{c}1,256 \\
954\end{array}$ & $\begin{array}{l}471 \\
189\end{array}$ & $\begin{array}{c}1,663 \\
527\end{array}$ & $\begin{array}{r}647 \\
85\end{array}$ & $\begin{array}{c}1,249 \\
758\end{array}$ & $\begin{array}{l}388 \\
184\end{array}$ & $\begin{array}{c}1,232 \\
489\end{array}$ & $\begin{array}{r}500 \\
59\end{array}$ & $\begin{array}{l}909 \\
744\end{array}$ \\
\hline $\begin{array}{l}\text { Mean intakc }{ }^{\ddagger} / \text { day of dietar) } \\
\text { tiber }(\mathrm{g}) \\
\text { saturated fat }(\mathrm{g}) \\
\text { protuin }(\mathrm{g}) \\
\text { alcohol }(\mathrm{g}) \\
\text { phosphorus (mg) }\end{array}$ & $\begin{array}{c}22 \\
24 \\
86 \\
18 \\
1,180\end{array}$ & $\begin{array}{c}25 \\
25 \\
96 \\
10 \\
1,659\end{array}$ & $\begin{array}{c}22 \\
26 \\
85 \\
16 \\
1,213\end{array}$ & $\begin{array}{c}25 \\
23 \\
94 \\
12 \\
1,539\end{array}$ & $\begin{array}{r}17 \\
22 \\
67 \\
10 \\
929\end{array}$ & $\begin{array}{r}20 \\
21 \\
77 \\
6 \\
315\end{array}$ & $\begin{array}{r}17 \\
22 \\
67 \\
10 \\
.955\end{array}$ & $\begin{array}{c}20 \\
21 \\
77 \\
7 \\
1,261\end{array}$ & $\begin{array}{r}15 \\
29 \\
72 \\
9 \\
928\end{array}$ & $\begin{array}{c}18 \\
27 \\
86 \\
5 \\
1,518\end{array}$ & $\begin{array}{r}17 \\
29 \\
75 \\
9 \\
1,004\end{array}$ & $\begin{array}{c}18 \\
27 \\
80 \\
7 \\
1,306\end{array}$ \\
\hline Family history (\%) & 12 & 12 & 12 & 12 & 13 & 15 & 13 & 14 & 12 & 14 & 12 & 13 \\
\hline Previous endoscopy $(\%)^{8}$ & 43 & 47 & 44 & 47 & 33 & 36 & 32 & 37 & 23 & 25 & 23 & 26 \\
\hline
\end{tabular}


Indication for endoscopy

(\%): blood in stool

occult blood

abdominal pain

diarrea

routine screening

$\begin{array}{ccccc}17 & 15 & 17 & 15 & 23 \\ 3 & 3 & 4 & 3 & 6 \\ 7 & 7 & 8 & 7 & 16 \\ 6 & 5 & 6 & 4 & 15 \\ 65 & 68 & 63 & 70 & 43\end{array}$

23
6
16
15
43

20
5
14
15
49

$\begin{array}{cc}22 & 20 \\ 5 & 5 \\ 17 & 14 \\ 16 & 17 \\ 45 & 48\end{array}$

$\begin{array}{ccc}24 & 21 & 24 \\ 5 & 5 & 4 \\ 17 & 16 & 16 \\ 18 & 14 & 15 \\ 40 & 47 & 44\end{array}$

Mean body mass index

25

25

26

25

25

24

24

24

24

24

25

$\left(\mathrm{kg} / \mathrm{m}^{2}\right)$

9

6

96

27

19

30

25

27

20

28

20

Standardized for age at baseline.

+ $\mathrm{Q} 1=$ quintile 1; $\mathrm{Q} 5=$ quintile 5 .

* Adjusted to total energy intake, by regression analysis.

The percent age of cases with previous negative endoscopies in the threc study populations was $26 \%, 34 \%$ and $16 \%$ respectively (see text). 
Among the men, screening was the indication for endoscopy in 53\% of cases and $67 \%$ of the controls; among the women, $33 \%$ of cases had endoscopy for screening, compared to $46 \%$ of the controls.

Bleeding, occult blood and family history were more important among male cases ( $21 \%$ vs. $15 \%$; $9 \%$ vs. $3 \%, 11 \%$ vs. $7 \%$, respectively) and female cases ( $37 \%$ vs. $22 \%$; $7 \%$ vs. $4 \%, 19 \%$ vs. $13 \%$, respectively). In multivariate models, indicator variables for previous endoscopies, indication for endoscopy, body mass index, alcohol, folate, dietary fiber and saturated fat intake were included. Physical activity was not significantly related to the risk in men or women and was not included in multivariate analyses. The mean size of polyps in both men and women was 1.0 centimeter.

\section{Calcium intake}

The median intakes of calcium in men, adjusted to 2,000 kcal/day, ranged from 560 $\mathrm{mg} /$ day in the lowest quintile to $1,500 \mathrm{mg} /$ day in the highest. In women, based on the 1980 questionnaire, the quintiles of median total calcium intake, adjusted to 1,600 $\mathrm{kcal} /$ day, ranged from 400 to $1,160 \mathrm{mg} /$ day, whereas the quintiles of median intake based on the extended 1984 questionnaire (which included specific questions on calcium supplements) were comparable to those of men: $480-1,550 \mathrm{mg} /$ day.

The total energy-adjusted calcium intake was not associated with the risk for colorectal adenoma in men or women (relative risk (RR), highest vs. lowest quintile of intake: men, 0.91, 95\% confidence interval (CI) 0.63-1.32; women, 1984-1988, 1.00, $95 \% \mathrm{CI}=0.68-1.46$; women, $1980-1988,0.94,95 \% \mathrm{CI}=0.66-1.33)$. This finding persisted after potentially confounding variables in further multivariate models were controlled for (Table 3.2) and after stratification (based on tertiles) by saturated fat intake, although a modest non-significant inverse association was suggested at higher intakes of saturated fat (RR for high calcium/high fat vs. low calcium/high fat: men, $0.80,95 \% \mathrm{CI}=0.49-1.29$; women, $0.79,95 \% \mathrm{CI}=0.49-1.25$; $\mathrm{RR}$ for high calcium/low fat vs. low calcium/low fat; men, $1.17,95 \% \mathrm{CI}=0.71-1.93$; women, $0.95,95 \% \mathrm{CI}=$ 0.56-2.86).

Dietary calcium (excluding supplement use) was also unrelated to the risk for adenoma after age, total energy and family history were controlled for (RR, highest vs. lowest quintile of dietary calcium intake, men, $0.90,95 \% \mathrm{Cl}=0.63-1.28$; women, $1984-1988,1.05,95 \% \mathrm{CI}=0.71-1.55$; women, $1980-1988,0.98,95 \% \mathrm{Cl}=0.69-1.39$ ), and in further multivariate models (Table 3.2). Neither calcium from dairy nor from non-dairy sources was related to adenoma risk (data not shown).

The calcium/phosphorus ratio was not related to polyp risk (RR adjusting to potentially confounding variables for the highest vs. lowest quintile of this ratio: men, 
$1.21,95 \% \mathrm{CI}=0.84-1.74$; women, $1.01,95 \% \mathrm{CI}=0.71-1.44$ ), nor was there any evidence of effect modification of calcium by level of phosphorus intake.

Higher intake of calcium was non-significantly inversely related to the risk for adenoma among men in the lowest tertile of vitamin $\mathrm{D}$ intake $(\mathrm{RR}=0.52,95 \% \mathrm{CI}=$ $0.22-1.21$, for high vs. low tertile of calcium) but no such association existed in women $(\mathrm{RR}=1.10,95 \% \mathrm{CI}=0.55-2.17)$.

Table 3.2 Relative risk" of colorectal adenoma among men and women, by quintiles of calcium intake and vitamin D intake: The Health Professionals Follow-up Study (HPFS) and The Nurses' Health Study (NHS).

\begin{tabular}{|c|c|c|c|c|c|c|}
\hline \multirow[b]{3}{*}{$\begin{array}{l}\text { Calcium } \\
\text { intake }\end{array}$} & \multicolumn{6}{|c|}{ Study population } \\
\hline & \multicolumn{2}{|c|}{ HPFS, 1986-1990 } & \multicolumn{2}{|c|}{ NHS, 1984-1988 } & \multicolumn{2}{|c|}{ NHS, $1980-1988$} \\
\hline & Total & Dietary & Total & Dietary & Total & Dietary \\
\hline \multicolumn{7}{|l|}{ Quintile } \\
\hline 1 (ref) & 1.00 & 1.00 & 1.00 & 1.00 & 1.00 & 1.00 \\
\hline 2 & 1.36 & 0.98 & 0.91 & 1.19 & 1.04 & 1.07 \\
\hline 3 & 1.41 & 1.10 & 1.29 & 1.01 & 1.49 & 1.50 \\
\hline 4 & 1.33 & 1.21 & 1.15 & 1.59 & 1.13 & 1.11 \\
\hline 5 & 1.13 & 1.01 & 1.16 & 1.18 & 1.17 & 1.21 \\
\hline \multicolumn{7}{|l|}{$95 \% \mathrm{Cl}^{\dagger} \mathrm{Q} 5$} \\
\hline vs. $Q 1^{\dagger}$ & $0.76-1.66$ & $0.70-1.46$ & $0.78-1.72$ & $0.79-1.78$ & $0.81-1.69$ & $0.84-1.74$ \\
\hline Trend $p^{\S}$ & 0.98 & 0.77 & 0.37 & 0.27 & 0.47 & 0.42 \\
\hline $\begin{array}{l}\text { Vitamin D } \\
\text { inlake }\end{array}$ & Total & Dietary & Total & Dietary & Total & Dietary \\
\hline \multicolumn{7}{|l|}{ Quintile } \\
\hline 1 (ref) & 1.00 & 1.00 & 1.00 & 1.00 & 1.00 & 1.00 \\
\hline 2 & 0.96 & 0.90 & 0.89 & 0.92 & 1.09 & 0.86 \\
\hline 3 & 0.83 & 1.00 & 0.91 & 0.80 & 0.80 & 1.07 \\
\hline 4 & 0.68 & 0.78 & 0.82 & 0.80 & 0.88 & 0.90 \\
\hline 5 & 1.29 & 1.05 & 1.04 & 1.09 & 0.68 & 0.97 \\
\hline $\begin{array}{l}95 \% \text { Cl Q5 } \\
\text { vs. Q1 }\end{array}$ & $0.87-1.93$ & $0.74-1.49$ & $0.65-1.67$ & $0.75-1.58$ & $0.41-1.13$ & $0.68-1.38$ \\
\hline Trend $p^{\S}$ & 0.32 & 0.82 & 0.86 & 0.64 & 0.09 & 0.93 \\
\hline
\end{tabular}

Adjusted for age, total energy intake, body mass index, alcohol consumption, folate, saturated fat and fiber intake, indications for endoscopy, history of endoscopy prior to the study period, and family history in logistic regression analysis.

$\mathrm{Cl}=95 \%$ confidence interval.

\# Energy-adjusted by regression analysis.

$\$$ Test for trend calculated by using the median of each quintile of intake as a continuous variable in logistic regression. 
Table 3.3 Relative risk" of left colon and rectal adenoma among men and women, by quintiles of energy-adjusted calcium and vitamin D intake: The Health Professionals Followup Study and The Nurses' Health Study (NHS).

\begin{tabular}{|c|c|c|c|c|c|}
\hline \multirow{3}{*}{\multicolumn{2}{|c|}{$\begin{array}{l}\text { Nutrient } \\
\text { Total calcium intake }\end{array}$}} & \multicolumn{4}{|c|}{ Study population } \\
\hline & & \multicolumn{2}{|c|}{ HPFS, 1986-1990 } & \multicolumn{2}{|c|}{ NHS, 1980-1988 } \\
\hline & & $\begin{array}{l}\text { Left colon } \\
(\mathrm{n}=251)\end{array}$ & $\begin{array}{l}\text { Rectum } \\
(\mathrm{n}=80)\end{array}$ & $\begin{array}{l}\text { Left colon } \\
(n=224)\end{array}$ & $\begin{array}{l}\text { Rectum } \\
(n=126)\end{array}$ \\
\hline \multirow[t]{5}{*}{ Quintile } & 1 (ref) & 1.00 & 1.00 & 1.00 & 1.00 \\
\hline & 2 & 1.25 & 1.93 & 0.91 & 1.26 \\
\hline & 3 & 1.15 & 2.59 & 1.52 & 1.40 \\
\hline & 4 & 1.22 & 1.85 & 1.17 & 1.07 \\
\hline & 5 & 1.02 & 1.61 & 1.33 & 0.90 \\
\hline \multicolumn{2}{|c|}{$95 \% \mathrm{Cl} \mathrm{Q5}$ versus $\mathrm{Q} 1^{\ddagger}$} & $0.66-1.58$ & $0.68-3.82$ & $0.85-2.08$ & $0.48-1.71$ \\
\hline \multicolumn{2}{|c|}{ Trend $p^{\S}$} & 0.86 & 0.78 & 0.15 & 0.50 \\
\hline \multicolumn{2}{|c|}{ Tolal vitamin $D$ intake } & Left colon & Rectum & Left colon & Rectum \\
\hline \multirow[t]{5}{*}{ Quintile } & $1(\mathrm{ref})$ & 1.00 & 1.00 & 1.00 & 1.00 \\
\hline & 2 & 0.96 & 0.95 & 1.26 & 0.86 \\
\hline & 3 & 0.83 & 0.86 & 0.91 & 0.67 \\
\hline & 4 & 0.72 & 0.58 & 1.15 & 0.54 \\
\hline & 5 & 1.35 & 1.00 & 1.05 & 0.30 \\
\hline \multicolumn{2}{|c|}{$95 \% \mathrm{CI}$ Q5 versus Q1 } & $0.86-2.13$ & $0.44-2.26$ & $0.56-1.93$ & $0.13-0.71$ \\
\hline \multicolumn{2}{|c|}{ Trend $p^{\S}$} & 0.26 & 0.82 & 0.98 & 0.005 \\
\hline
\end{tabular}

- Adjusted for age, total energy intake, body mass index, alcohol consumption, folate, saturated fat and fiber intake, indications for endoscopy, history of endoscopy prior to the study period, and family history in logistic regression analysis.

* Adjusted by regression analysis.

* $\mathrm{Cl}$, confidence interval.

3 Test for trend calculated by using the median of each quintile of intake as a continuous variable in logistic regression.

Calcium intake was not associated with the risk for polyps of the left colon or the rectum (Table 3.3) and no differences were observed between small and larger polyps (Table 3.4). Calcium intake was not associated with risk for either prevalent or incident cases in men (prevalent cases, $\mathrm{RR}=1.11,95 \% \mathrm{CI}=0.71-1.73$; incident cases, $\mathrm{RR}$ $=1.30,95 \% \mathrm{CI}=0.57-2.94$ ) and women (data not shown).

\section{Vitamin $D$}

The median total energy-adjusted vitamin D intake, in men ranged from 125 to 851 IU/day between the first and fifth quintiles, vitamin $D$ intake from dietary sources 
ranged from 101 to $470 \mathrm{IU} / \mathrm{day}$. In women, the median total energy-adjusted intake ranged from 61 to $653 \mathrm{IU} /$ day in 1980 and from $87 \mathrm{lo} 682 \mathrm{IU} /$ day in 1984; dietary vitamin D ranged from 52 to $315 \mathrm{IU} /$ day in $198($ ), and from 72 to $329 \mathrm{IU} / \mathrm{day}$ in 1484 .

Table 3.4 Relative risk" of small $(<1 \mathrm{~cm})$ and large $(z 1 \mathrm{~cm})$ adenoma among men and women, by quintiles of energy-adjusted ${ }^{\dagger}$ calcium and vitamin $\mathrm{D}$ intake: The Health Professionals Follow-up Study (HPFS) and The Nurses' Health Study (NHS).

Study population

Nutrient HPFS, 1986-1990

NHS, $1980-1988$

\begin{tabular}{|c|c|c|c|c|c|}
\hline \multicolumn{2}{|c|}{ Total calcium intake } & $\begin{array}{c}\text { Small } \\
(n=151)\end{array}$ & $\begin{array}{c}\text { Large } \\
(n=128)\end{array}$ & $\begin{array}{c}\text { Small } \\
(n=173)\end{array}$ & $\begin{array}{c}\text { Large } \\
(n=145)\end{array}$ \\
\hline \multirow[t]{5}{*}{ Quintile } & $1(\mathrm{rcf})$ & 1.00 & 1.00 & 1.00 & 1.00 \\
\hline & 2 & 1.11 & 1.73 & 0.91 & 1.16 \\
\hline & 3 & 1.18 & 1.82 & 1.71 & 1.14 \\
\hline & 4 & 1.13 & 1.40 & 1.24 & 1.13 \\
\hline & 5 & 1.22 & 1.16 & 1.05 & 1.26 \\
\hline \multicolumn{2}{|c|}{$95 \% \mathrm{Cl}$ Q5 versus $\mathrm{Q} 1^{*}$} & $0.72-2.09$ & $0.61-2.22$ & $0.62-1.79$ & $0.72-2.19$ \\
\hline \multicolumn{2}{|c|}{ Trend $\mathrm{p}^{8}$} & 0.51 & 0.72 & 0.75 & 0.49 \\
\hline \multicolumn{2}{|c|}{ Total vitamin $D$ intake } & Small & Large & Small & Large \\
\hline \multirow[t]{5}{*}{ Quintile } & 1 (ref) & 1.00 & 1.00 & 1.00 & 1.00 \\
\hline & 2 & 0.77 & 1.47 & 1.22 & 1.04 \\
\hline & 3 & 0.83 & 1.01 & 1.04 & 0.68 \\
\hline & 4 & 0.57 & 0.89 & 0.87 & 1.02 \\
\hline & 5 & 1.05 & 1.67 & 0.65 & 0.85 \\
\hline \multicolumn{2}{|c|}{$95 \% \mathrm{Cl}$ Q5 versus Q1 } & $0.59-1.89$ & $0.87-3.22$ & $0.31-1.34$ & $0.39-1.83$ \\
\hline \multicolumn{2}{|c|}{ Trend $p^{\S}$} & 0.94 & 0.36 & 0.15 & 0.71 \\
\hline
\end{tabular}

- Adjusted for age, total energy intake, body mass index, alcohol consumption, folate, saturated fat and fiber intake, indications for endoscopy, history of endoscopy prior to the study period, and family history in logistic regression analysis.

Adjusted by regression analysis.

* $\mathrm{Cl}=$ confidence interval.

$\$$ Test for trend calculated by using the median of each quintile of intake as a continuous variable in logistic regression.

When age, energy intake and family history were adjusted for, a slight inverse, nonsignificant association for energy-adjusted vitamin $\mathrm{D}$ intake was observed in men $(\mathrm{RR}=0.85,95 \% \mathrm{CI}=0.61-1.19)$. In multivariate analysis, this association disappeared (Table 3.2). In the 1984-1988 follow-up among women, a similar lack of association was observed (Table 3.2). In the 1980-1988 follow-up among women, total vitamin D 
intake was inversely associated with the risk of adenoma $(\mathrm{RR}=0.61,95 \% \mathrm{CI}=$ $0.43-0.87, p=0.002$ ), when age, total energy intake and family history were adjusted for. This association did not remain significant in multivariate analysis (Table 3.2), which included folate intake. The Pearson correlation between folate and vitamin D intake in this cohort was $0.58 .^{52}$ No clear trend with duration of multivitamin use was evident.

The inverse association with total vitamin D intake among women in the 1980-1988 follow-up was significant for rectal adenomas (Table 3.3), for which an inverse association with dietary vitamin D intake was observed as well (RR highest vs. lowest quintile $=0.64,95 \% \mathrm{CI}=0.35-1.17$ ). No important differences were observed between cases with large polyps versus those with small ones (Table 3.4) or between prevalent and incident cases in men (prevalent cases, $\mathrm{RR}=1.09,95 \% \mathrm{CI}=0.68-1.76$; incident cases, $\mathrm{RR}=2.07,95 \% \mathrm{CI}=0.96-4.46$ ) or women in the 1984-1988 follow-up (data not shown). The apparent inverse association with vitamin $D$ in the 1980-1988 follow-up was only observed in women who had not previously undergone endoscopy (prevalent cases, $\mathrm{RR}=0.53,95 \% \mathrm{Cl}=0.30-0.93$; incident cases, $\mathrm{RR}=2.19,95 \% \mathrm{CI}$ $=0.64-7.53)$. However, in this follow-up period, the number of incident cases (16\%) was too small for drawing firm conclusions.

\section{Dairy products}

After 4 years of follow-up, no association was found between the consumption of whole milk or low-fat or skim milk and the risk for colorectal adenoma in men or women (Table 3.5). In the 1980-1988 follow-up, low-fat or skim milk was inversely, although not significantly, related to the risk for adenoma ( $R R=0.87$, Table 3.5).

The fermented dairy products (yogurt, sour cream, cottage cheese, cream cheese and other cheese) combined either by calcium content (data not shown) or by the weight of the normal portion size were not associated with the risk for adenoma in men (Table 3.5). For women in the 1984-1988 and 1980-1988 follow-ups, a nonsignificant inverse association was observed. Adjusting for saturated fat intake did not change these findings appreciably.

For specific fermented dairy products an inverse nonsignificant association was observed for yogurt in men and women ( $R \mathrm{R}$ for consumption of 1 cup more than four times per week vs. almost never: men, $0.66 ; 95 \% \mathrm{CI}=0.28-1.46$, trend $\mathrm{p}=0.07$; women, $1984-1988,0.85,95 \% \mathrm{Cl}=0.43-1.70$, trend $\mathrm{p}=0.10$; women, $1980-1988$, $0.60,95 \% \mathrm{CI}=0.30-1.18$ trend $\mathrm{p}=0.11$ ).

Among men, this association became weaker when saturated fat intake was adjusted for (RR for consumption of 1 cup more than four times per week vs. almost never $=0.70,95 \% \mathrm{CI}=0.31-1.62$, trend $\mathrm{p}=0.19$ ) and it further diminished controlling 
for other potential confounders (RR for consumption of 1 cup more than 4 times per week vs. almost never $=0.89,95 \% \mathrm{Cl}=0.39-2.07$, trend $\mathrm{p}=0.63$ ). Among men an inverse association with sour cream consumption was observed (RR for consumption of 1 tablespoon more than once per week vs. almost never $=0.67,95 \% \mathrm{CI}=0.37$ $1.22)$, and this remained after adjustment for saturated fat intake ( $R R=0.61,95 \% \mathrm{CI}$ $=0.33-1.11$, trend $p=0.06$ ) and other potential confounders ( $R R$ for consumption more than once a week vs. never $=0.62,95 \% \mathrm{CI}=0.34-1.13$, trend $\mathrm{p}=0.07$ ).

Sour cream consumption was not associated with risk in women in the 1984-1988 follow-up (RR for consumption of 1 tablespoon more than once per week vs. never $=0.88,95 \% \mathrm{CI}=0.48-1.61$, trend $\mathrm{p}=0.54$ ). In 1980 the questionnaire did not include this product. Hard cheese, a fermented product with a high fat content was positively associated with the risk of colorectal polyps in men (RR for consumption of 1 slice or 1 ounce serving more then 4 times a week vs. never $=1.45$ (Table 3.5). After adjustment for saturated fat intake, this association diminished $(R R=1.28$, Table 3.5). Adjusting for other possible confounders did not materially affect this. The positive association with hard cheese was not observed for women in the 1984-1988 follow-up $(\mathrm{RR}=1.16$, Table 3.5), nor those in the 1980-1988 follow-up $(\mathrm{RR}=0.91$, Table 3.5). The consumption of cottage cheese and cream cheese was not related to adenoma risk in men and women (data not shown).

\section{Discussion}

These prospective data do not support an important association of calcium or milk intake with the occurrence of colorectal adenomas. Some slight support for the hypothesis that vitamin $\mathrm{D}$ intake is protective against rectal adenoma is provided for women using the 1980 questionnaire, but no effect of vitamin $D$ on adenoma risk was observed among men and in the 1984-1988 follow-up among women.

Most studies on calcium or milk intake and colorectal cancer development examined the ultimate disease and not colorectal adenomas. If calcium indeed influences the cell proliferation of colonic epithelium, ${ }^{5,6}$ the failure to find an inverse association with cancer could be due to a long time period required for the development of cancer. Our analyses do not suggest an effect of calcium on adenoma development or progression, as no differences between small and larger adenomas were observed. Our findings on calcium and milk intake are consistent with a hospital-based case-control study ${ }^{37}$ on adenomas ( $R R$ for calcium, highest versus lowest quartile $=1.28$; RR for milk, highest versus lowest quartile $=0.90) .{ }^{37}$ 
Table 3.5 Relative Risk' of colorectal adenoma among men and women, by categories of dairy product consumption: The Health Professionals Follow-up Study (HPFS) and The Nursus" Health Study (NHS).

\begin{tabular}{|c|c|c|c|c|c|c|c|c|}
\hline \multirow[b]{3}{*}{ Dairy product } & & & \multirow{2}{*}{\multicolumn{2}{|c|}{ HPFS, 1986-1990 }} & \multicolumn{2}{|c|}{ Study population } & \multirow{2}{*}{\multicolumn{2}{|c|}{ NHS, 1980-1988 }} \\
\hline & & & & & NHS, & $\cdot 1988$ & & \\
\hline & & & $\mathrm{RR}^{\circ}$ & $\mathrm{RR}^{\prime}$ & $\mathrm{RR}^{\circ}$ & $\mathrm{RR}^{\ddagger}$ & $\mathrm{RR}^{\circ}$ & $\mathrm{RR}^{\ddagger}$ \\
\hline \multirow{7}{*}{$\begin{array}{l}\text { Milk } \\
\text { (whole) }\end{array}$} & \multirow[t]{5}{*}{ Category ${ }^{5}$ of consumption } & 1 (ref) & 1.00 & 1.00 & 1.00 & 1.00 & 1.00 & 1.00 \\
\hline & & 2 & 1.14 & 1.07 & 1.10 & 1.10 & 0.60 & 0.59 \\
\hline & & 3 & 1.12 & 1.00 & 1.31 & 1.30 & 1.06 & 1.05 \\
\hline & & 4 & 0.99 & 0.86 & 0.99 & 1.00 & 0.92 & 0.89 \\
\hline & & 5 & 0.94 & 0.75 & 1.61 & 1.70 & 1.46 & 1.35 \\
\hline & \multicolumn{2}{|c|}{$95 \% \mathrm{Cl}^{+}$highest vs. lowest intake } & $0.38-2.34$ & $0.29-1.91$ & $0.69-3.76$ & $0.71-4.03$ & $0.82-2.57$ & $0.76-2.41$ \\
\hline & \multicolumn{2}{|c|}{ Trend $p^{\prime}$} & 0.88 & 0.51 & 0.25 & 0.23 & 0.61 & 0.88 \\
\hline \multirow{7}{*}{$\begin{array}{l}\text { Milk (skim/low } \\
\text { fat) }\end{array}$} & \multirow[t]{5}{*}{ Category ${ }^{5}$ of consumption } & 1 (ref) & 1.00 & 1.00 & 1.00 & 1.00 & 1.00 & 1.00 \\
\hline & & 2 & 0.94 & 0.98 & 0.93 & 0.93 & 0.72 & 0.73 \\
\hline & & 3 & 1.09 & 1.14 & 1.21 & 1.20 & 0.73 & 0.75 \\
\hline & & 4 & 0.91 & 0.97 & 0.93 & 0.93 & 0.79 & 0.81 \\
\hline & & 5 & 1.02 & 1.06 & 1.09 & 1.09 & 0.87 & 0.91 \\
\hline & \multicolumn{2}{|c|}{ 95\% CI highest vs. lowest intake } & $0.70-1.49$ & $0.72-1.54$ & $0.73-1.63$ & $0.73-1.63$ & $0.50-1.50$ & $0.63-1.30$ \\
\hline & \multicolumn{2}{|c|}{ Trend $p$} & 0.71 & 0.93 & 0.98 & 0.96 & 0.18 & 0.29 \\
\hline \multirow{7}{*}{$\begin{array}{l}\text { Fermented dairy } \\
\text { products }^{*}\end{array}$} & \multirow[t]{5}{*}{ Category' of consumption } & $1(\mathrm{rch})$ & 1.00 & 1.00 & 1.00 & 1.00 & 1.00 & 1.00 \\
\hline & & 2 & 1.18 & 1.14 & 0.95 & 0.94 & 0.98 & 0.97 \\
\hline & & 3 & 1.44 & 1.34 & 0.88 & 0.87 & 1.04 & 1.03 \\
\hline & & 4 & 1.39 & 1.33 & 0.89 & 0.88 & 1.06 & 1.06 \\
\hline & & 5 & 1.10 & 1.06 & 0.75 & 0.75 & 0.87 & 0.89 \\
\hline & \multirow{2}{*}{\multicolumn{2}{|c|}{$\begin{array}{l}95 \% \mathrm{Cl} \text { highest vs. lowest intake } \\
\text { Trend } \mathrm{p}\end{array}$}} & $0.75-1.62$ & $0.72-1.57$ & $0.51-1.11$ & $0.51-1.11$ & $0.62-1.23$ & $0.63-1.25$ \\
\hline & & & 0.90 & 0.85 & 0.16 & 0.17 & 0.39 & 0.50 \\
\hline
\end{tabular}




\begin{tabular}{|c|c|c|c|c|c|c|c|c|}
\hline \multirow[t]{7}{*}{ Hard cheese } & Category " of consumption & (теf) & 1.00 & 1.00 & 1.00 & 1.00 & 1.00 & 1.00 \\
\hline & 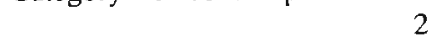 & & 0.91 & 0.88 & 0.99 & 0.97 & 1.23 & 1.23 \\
\hline & 3 & & 1.32 & 1.22 & 0.98 & 0.95 & 0.94 & 0.93 \\
\hline & 4 & & 1.45 & 1.28 & 0.85 & 0.81 & 1.08 & 1.04 \\
\hline & 5 & & - & - & 1.16 & 1.16 & 0.91 & 0.81 \\
\hline & $95 \% \mathrm{Cl}$ highest vs. lowest intake & & $1.02-2.05$ & $0.88-1.86$ & $0.51-2.63$ & $0.49-2.75$ & $0.45-1.83$ & $0.40-1.67$ \\
\hline & Trend $\mathrm{p}$ & & 0.03 & 0.24 & 0.48 & 0.38 & 0.87 & 0.65 \\
\hline
\end{tabular}

- Adjusted for age, total energy and family history in logistic regression.

- $\mathrm{CI}=$ confidence interval.

- Adjusted for age, total energy, family history and saturated fat intake.

8 Frequency of using one $8 \mathrm{oz}$ glass: $1=$ almost never; $2=1-4$ per month (men), $1-3$ times per month (women); $3=2-4$ times per week (men), $1-4$ per week (women); $4=5-7$ times per week; $5=$ more then once per day.

I Using consumption frequency as a continuous variable in logistic regression analysis.

- Median of intake (g/day): men: $1=4 ; 2=14 ; 3=27 ; 4=46 ; 5=111$; women $1980(1984) ; 1=10(10) ; 2=20(21) ; 3=36(34) ; 4=59(60) ; 5=134(129)$.

* Yogurt, sour cream, cream cheese, cottage cheese, hard cheese (American, Cheddar etc.).

- Frequency of using 1 slice or 1 oz serving: $1=$ less then 3 times per month; $2=$ once per week; $3=2-4$ times per week; $4=$ more then 4 times per week (men), 5-7 limes per week (women), $5=$ more then once per day (women). 
Moreover, in a screening-based case-control study of colorectal adenomas, no association was observed (or was not presented). ${ }^{39}$

Previous epidemiologic studies focusing on colorectal cancer and milk consumption or calcium intake have not been conclusive. A population-based case-control study in Utah suggests a significant inverse association between calcium and dairy products and colorectal cancer risk: men and women in the upper quartile of intake had half the risk of those in the lowest quartile. " A non-significant inverse association between milk consumption and risk of colon cancer was observed among Seventh Day Adventists in the United States, ${ }^{15}$ while other case-control studies do not support an inverse association with calcium and/or milk consumption. ${ }^{16-18}$

In a prospective study on colorectal cancer among 11,888 residents of a retirement community in California, that used a self-administered food frequency questionnaire listing 56 foods or food groups 126 incident cases were confirmed after 4 years of follow-up. ${ }^{14}$ In this study, a slight, but not significant association with calcium intake was observed ( $R R$ for men, highest vs. lowest tertile $=0.86,95 \% \mathrm{CI}=0.4-1.7$ ).

One prospective study, using 28-day dietary histories suggested a significant inverse association between calcium and the risk for colorectal cancer (49 cases) among 1,954 male employees of the Western Electric Company. ${ }^{13}$ Based on the results of this study and the Utah case-control study, Garland and co-workers suggest a linear dose-response relation between the intake of 700-1,200 $\mathrm{mg}$ of calcium per day and colon cancer risk. They hypothesize a very low incidence for calcium intake of $1,800 \mathrm{mg} /$ day in men and $1,500 \mathrm{mg} /$ day in women. ${ }^{53}$ According to the calculations of Newmark et al. ${ }^{5}$, a calcium intake of $1,500 \mathrm{mg} /$ day or more is necessary for individuals with diets high in fat (150 $\mathrm{g} /$ day), and phosphate (1,500 mg/day), to neutralize the average fatty acid and bile-acid concentration in the bowel. In our studies, $11 \%$ of the male population had an intake of $1,500 \mathrm{mg} /$ day or more, and $4 \%$ of the female population had a daily intake of 1,500 $\mathrm{mg} /$ day or more in 1980 , compared to $15 \%$ in 1984 (calcium-containing supplements were not included on the 1980 questionnaire). A substantial proportion of participants in our studies should have been consuming an adequate amount of calcium to experience the biologic effects, especially since fat intake was lower than used in the calculations of Newmark et al. (mean, $69 \mathrm{~g} /$ day in women and $80 \mathrm{~g} /$ day in men). ${ }^{47.50}$

The failure to demonstrate an association with calcium intake may be explained by the relatively low intake of saturated fat and high intake of dietary fiber among men in the HPFS compared to the general male population. ${ }^{39}$ However, the association with calcium did not differ at different levels of saturated fat or dietary fiber intake. Neither was the calcium/phosphorus ratio associated with adenoma risk.

In a cohort of Hawaiian-Japanese men, total calcium intake, estimated using 24-hour recalls, was not related to colorectal cancer on the whole,${ }^{54.56}$ but an inverse association 
was observed for sigmoid colon cancer. ${ }^{56}$ We did not observe a difference of the effect of calcium between subsites among men or women. Alternatively, the proliferative effect of fatty acids and bile acids may be especially important for the right side of the colon. $^{57}$ If calcium binds these substances and thereby reduces the risk of colon cancer, this protective effect may be most important for the caecum and ascending colon. An effect on right-sided polyp risk could not be assessed in our study.

A possible protective effect of vitamin $\mathrm{D}$ was initially suggested by the data for the women in the 1980-1988 follow-up, but could not be confirmed during the 1984-88 follow-up of the women or the 4-year follow-up of the men. Latency time did not explain this difference: when the 8-year follow-up using the 1980 questionnaire was separated into two 4-year periods, the inverse association with total vitamin $D$ intake remained in both periods. The apparent protective effect among women during the 1980-1988 follow-up seemed to be mainly attributable to multivitamin supplements containing vitamin $\mathrm{D}$. The 1980 version of the questionnaire included questions on multivitamin use (dose, frequency, brand name, and duration), but no separate questions on the intake of calcium or vitamin D supplements. However, the use of multivitamins contributed substantially to vitamin $\mathrm{D}$ intake. The observed association with total vitamin $\mathrm{D}$ intake may be difficult to interpret because of the intercorrelations with other vitamins and minerals in multivitamin supplements that include folate. ${ }^{52}$ As diet is probably measured closer to the onset of disease in women who did undergo endoscopy before the study period, a stronger association with vitamin $\mathrm{D}$ intake would have been expected. This was not confirmed by our findings; the association with vitamin D intake was stronger among 'prevalent' cases. (Note: this study addresses dietary and supplemental intake of vitamin $\mathrm{D}$, and does not take sunlight exposure into account).

In the Western Electric cohort, a dietary intake of more than $3.75 \mu \mathrm{g}$ (150 IU/day) of vitamin D per day was associated with a $50 \%$ reduction in the incidence of colorectal cancer in men. ${ }^{13}$ In a prospective nested case-control study of 8,006 Hawaiian-Japanese men (159 cases) using a 24-hour recall method, a slight negative association with rectal cancer risk was observed. ${ }^{55}$

The intake of fermented dairy products as a single food group did not seem to be related to the risk for colorectal adenomas. The median of intake in the highest quintile was $111 \mathrm{~g} /$ day for men and $128 \mathrm{~g} /$ day for women using the 1986 and 1984 questionnaire, respectively. This contrasts with intakes of $225 \mathrm{~g} /$ day or more in a Dutch case-control study in which fermented dairy products were seen to have a protective effect against breast cancer. ${ }^{28}$ Thus, the limited range of intake in our population may have reduced the power to detect the hypothesized association with fermented products. Combining fermented products into one food group has disadvantages, as the products 
differ in their fat content, strains of microorganisms and enzymes. Different microorganisms might have different effects on the bowel flora or immunocompetent cells in the colon mucosa. ${ }^{33}$ Analyses using single food items were limited by the large number of participants who reported infrequent consumption of particular products and the restricted range of intake.

In summary, these data do not support an inverse association between calcium intake and the occurrence of adenomatous polyps in men and women. The slight inverse association with vitamin $D$ observed in only one of the two data sets of women was mainly attributable to the use of vitamin supplements that include other potentially protective components such as folate, ${ }^{52}$ and should therefore be interpreted with considerable caution. However, the observation of a stronger association of rectal polyps with vitamin D from both supplements and diet in women suggests that further investigation may be useful. These data generally do not support the existence of other factors in dairy products protective against colorectal adenoma. However, they do not exclude an effect of higher levels of intake of dairy products, nor do they exclude an effect in the proximal colon. In addition, further study is required to examine the potential influences of dairy products on later stages of carcinogenesis.

\section{References}

1. Willett WC. The search for the causes of breast and colon cancer. Nature 1989;338:389-394.

2. Gerhardsson de Verdier M, Hagman U, Peters RK, et al. Meat, cooking methods and colorectal cancer: a case-referent study in Stockholm. Int J Cancer 1991;49:520-525.

3. Steinmetz KA and Potter JD. Vegetables, fruit and cancer. I. Epidemiology. Cancer Causes Control 1991;2:325-357.

4. Sorenson AW, Slattery ML, Ford MH. Calcium and colon cancer: a review. Nutr Cancer 1988;11:135-145.

5. Newmark HL, Wargovich MJ, Bruce WR. Colon cancer and dietary fat, phosphate, and calcium: a hypothesis. J Natl Cancer Inst 1984;72:1323-1325.

6. Wargovich MJ, Eng VWS, Newmark HL, Bruce WR. Calcium ameliorates the toxic effect of deoxycholic acid on colonic epithelium. Carcinogenesis 1983;4:1205-1207.

7. Lipkin $M$ and Newmark $H$. Effect of added dietary calcium on colonic epithelial-cell proliferation in subjects of high risk for familial colonic cancer. N Engl J Med 1985;313:13811384.

8. McKeown-Eyssen GE and Bright-See E. Dietary factors in colon cancer: international relationships. Nutr Cancer 1984;6:160-170.

9. International Agency for Research on Cancer, Intestinal Microbiology Group. Dietary fiber, transit time, faecal bacteria, steroids and colon cancer in two Scandinavian populations. Lancet 1977;2:207-211.

10. Rosen M, Nyström L, Wall S. Diet and cancer mortality in the counties of Sweden. Am J Eipidemiol 1988:127:42-49.

11. Slattery ML, Sorenson AW, Ford MH. Dictary calcium intake as a mitigating factor in colon cancer. Am J Epidemiol 1988;128:504-514.

12. Kune S, Kune GA, Watson IF. Case-control study of dietary etiological factors: The Melbourne colorectal cancer study. Nutr Cancer 1987;9:21-42. 
13. Garland CF, Shekelle RB, Barrett-Connor E, Criqui MH, Rossof AH, Paul O. Dietary calcium and vitamin D and risk of colorectal cancer: a 19-year prospective study in men. Lancet 1985; 1:307-309.

14. Wu AH, Paganini-Hill A, Ross RK, Henderson BE. Alcohol, physical activity and other risk factors for colorectal cancer: a prospective study. Brit J Cancer 1987;55:687-694.

15. Phillips RL. Role of life-style and dietary habits in risk of cancer among seventh-day adventists. Canc Res 1975;35:3513-3522.

16. Jain M, Cook GM, Davis FG, et al. A case-control study of diet and colorectal cancer. Int J Cancer 1980;26:757-768.

17. Manousos O, Day NE, Trichopoulos D, Gerovassilis F, Tzonou A, Polychronopoulou A. Diet and colorectal cancer: a case-control study in Greece. Int J Cancer 1983;32:1-5.

18. Negri E, La Vecchia C, D’Avanzo B, Franceschi S. Calcium, dairy products and colorectal cancer. Nutr Cancer 1990;13:255-262.

19. Garland CF and Garland FC. Do sunlight and vitamin D reduce the risk of colon cancer? Int J Epidemiol 1980;9:227-231.

20. Emerson JC and Weiss NS. Colorectal cancer and solar radiation. Cancer Causes Control 1992;3:95-99.

21. Eisman JA, Barkla DH, Tutton PJM. Suppression of in vivo growth of human cancer solid tumor xenographs by 1,25-dihydroxyvitamin $D_{3}$. Cancer Res 1987;47:21-25.

22. Lointier $P$, Wargovich $M J$, Saez $S$, et al. The role of vitamin $D_{3}$ in the proliferation of human colon cancer cell lines in vitro. Anticancer Rcs 1987;7:817-822.

23. Wargovich MJ and Lointier PH. Calcium and vitamin D modulate mouse colon epithelial cell prolifcration and growth characteristics of a human colon tumor cell line. Can J Physiol Pharma 1987;65:472-477.

24. Hitchins AD and McDonough FE. Prophylactic and therapeutic aspects of fermented milk. Am J Clin Nutr 1989;49:675-684.

25. Friend BA and Shahani KM. Antitumor properties of lactobacilli and dairy products fermented by lactobacilli. J Food Protect 1984;47:717-723.

26. Schackelford LA, Rao DR, Chawan CB, Pulusani SR. Effect of feeding fermented milk on the incidence of chemically induced colon tumors in rats. Nutr Cancer 1983;5:159-164.

27. Lê MG, Moulton LH, Hill C, Kramar A. Consumption of dairy produce and alcohol in a casecontrol study of breast cancer. J Natl Cancer Inst 1986;77:633-636.

28. van 't Veer P, Dekker JM, Lamers JWJ, et al. Consumption of fermented milk products and breast cancer: a case-control study in the Netherlands. Cancer Res 1989;49:4020-4023.

29. Goldin BR and Gorbach SL. Effect of lactobacillus acidophilus dietary supplements on 1,2 dimethylhydrazine dihydrochloride-induced intestinal cancer in rats. J Natl Cancer Inst 1980;64:263-265.

30. Goldin BR and Gorbach SL. The effect of milk and lactobacillus feeding on human intestinal bacterial enzyme activity. Am J Clin Nutr 1984;39:756-761.

31. Marteau P, Pochart P, Flourić B, et al. Effects of chronic ingestion of a fermented dairy product containing lactobacillus acidophilus and bifidobacterium bifidum on metabolic activities of the colonic flora in humans. Am J Clin Nutr 1990:52:685-688.

32. De Simone C, Bianchi Salvadori B, Negri R, Ferrazzi M, Baldinelli L, Vesely R. The adjuvant effect of yogurt on production of gamma-interferon by con A-stimulated human peripheral blood lymphocytes. Nutr Rep Int 1986;33:419-433.

33. Perdigon G, Nader de Macias ME, Alvarez. S, et al. Effect of a mixture of lactobacillus casei and lactobacillus acidophilus administered orally on the immune system in mice. $J$ Food Protect 1986;49:986-989.

34. Gorbach SL and Goldin BR. Nutrition and the gastrointestinal microflora. Nutr Rev 1992;50:378-381.

35. Young TB and Wolf DA. Case-control study of proximal and distal colon cancer and diet in Wisconsin. Int J Cancer 1988;42:167-175.

36. Peters RK, Pike MC, Garabrant D, Mack TM. Diet and colon cancer in Los Angeles County, 
California. Cancer Causes Control 1992;3:457-473.

37. Macquart-Moulin G, Riboli E, Cornée J, Kaaks R, Berthezène P. Colorectal polyps and diet: a case-control study in Marseilles. Int J Cancer 1987;40:179-188.

38. Kune GA, Kune S, Read A, Macgowan K, Penfold C, Watson LF. Colorectal polyps, diet, alcohol, and family history of colorectal cancer: a case-control study. Nutr Cancer 1991;16:25-30.

39. Little J, Logan RFA, Harotin PG, et al. Colorectal adenomas and diet - a case-control study. Brit J Cancer 1993;67:177-184.

40. Giovannucci E, Stampfer MJ, Colditz GA, Rimm EB, Willett WC. Relation of diet to the risk of colorectal adenoma in men. J Natl Cancer Inst 1992;84:91-98.

41. Rimm EB, Stampfer MJ, Colditz GA, et al. Effectiveness of various mailing strategies among nonrespondents in a prospective cohort study. Am J Epidemiol 1990;131:1068-1071.

42. Willett WC, Stampfer MJ, Colditz GA, Rosner BA, Speizer FE. Relation of meat, fat, and fiber intake to the risk of colon cancer in a prospective study among women. $\mathrm{N}$ Eng $\mathrm{J}$ Med 1990;323:1664-1672.

43. Rimm EB, Giovannucci E, Willett WC, et al. Prospective study of alcohol consumption and risk of coronary disease in men. Lancet 1991;338:464-468.

44. US Department of Agriculture: Agricultural Handbook No. 8 series. Composition of Foods, Raw, Processed and Prepared. Washington, DC:US Govt Print Off, 1963-1988.

45. Paul AA and Southgate DA. McCance and Widdowson's the Composition of Foods, 4th ed, revised. London: HM Stat Off, 1979.

46. Willett WC. Nutritional Epidemiology. New York: Oxford University Press, 1990.

47. Willett WC, Sampson L, Stampfer MJ, et al. Reproducibility and validity of a semi-quantitative food frequency questionnaire. Am J Epidemiol 1985:122:51-65.

48. Willett WC, Sampson L, Browne ML, et al. The use of a self-administered questionnaire to assess diet four years in the past. Am J Epidemiol 1988;127:188-199.

49. Salvini $S$, Hunter DJ, Sampson $L$, et al. Food bascd validation of a dietary questionnaire: the effects of week-to-week variation in food consumption. Int J Epidemiol 1989:18:858-867.

50. Rimm EB, Giovannucci E, Stampfer MJ, et al. Reproducibility and validity of an expanded selfadministered, semi-quantitative food frequency questionnaire among male health professionals. Am J Epidemiol 1992:135:1114-1126.

51. Feskanich D, Rimm EB, Giovannucci E, et al. Reproducibility and validity of food intake measurements using a semi-quantitative food frequency questionnaire. I Am Diabetic Assn 1993;93:790-796.

52. Giovannucci E, Stampfer MJ, Colditz GA, et al. Folate, methionine and alcohol intake and risk of colorectal adenoma. J Natl Cancer Inst 1993;85:875-884.

53. Garland CF, Garland FC, Gorham ED. Can colon cancer incidence and death rate be reduced with calcium and vitamin D? Am J Clin Nutr 1991:54:193S-201S.

54. Heilbrun LK, Hankin JH, Nomura A, Stemmermann GN. Colon cancer and dietary fat, phosphorus, and calcium in Hawaiian-Japanese men. Am J Clin Nutr 1986;43:306-309.

55. Heilbrun LK, Nomura A, Hankin JH, Stemmermann GN. Dietary vitamin D and calcium and the risk of colorectal cancer. Lancet 1985;1:925.

56. Stemmermann GN, Nomura A, Chyou PH. The influence of dairy and nondairy calcium on subsite large bowel cancer risk. Dis Colon Rectum 1990;33:190-194.

57. McMichael AJ and Potter JD. Host factors in carcinogenesis: certain bile-acid metabolic profiles that selectively increase the risk of proximal colon cancer. J Natl Cancer Inst 1985;75:185-191. 


\section{Chapter 4}

Design, conduct and validity of the case-control study 


\section{Contents}

\section{Extended abstract}

Case recruitment

Control recruitment

Non-response

Collection and validity of dietary intake data Implications

\section{Study population}

\section{Principles}

Definition of cases and controls

Study size and duration

Recruitment of cases

Procedures of case recruitment

Cooperation of hospitals

Eligibility of invited cases

Response and participation of cases

Determinants of invitation and participation

Implications of case recruitment

Recruitment of controls

Rationale

Procedures for control recruitment

Cooperation of general practitioners

Cooperation of municipal registries

Participation of GP-mediated controls

Municipal and GP-mediated controls

Implications of control recruitment

Indicators of non-response

\section{Collection and validity of the data}

Short questionnaire

Home interview

Alterations of the questionnaire during the interview period 


\section{Extended abstract}

Since selection bias is an inherent concem in case-control studies, this chapter concentrates on recruitment of cases and controls, and discusses its implications regarding internal and external validity. The different steps in the recruitment procedures are evaluated, which might be of special interest to those intending to conduct a case-control study on cancer in the Netherlands. Furthermore, the collection and validity of the dietary data are discussed and some issues relevant to potential information bias are evaluated.

\section{Case recruitment}

Recruitment of cases was planned to cover two and a half years, in which dietary history data of 250 cases (ICD-O 153) and 250 age- and sex-stratified controls would be gathered in the catchment area of the Comprehensive Cancer Centre Middle Netherlands. Cases were invited by surgeons in general hospitals covering the area. The cancer registry was used as a check of completeness and provided additional clinical and pathological information. In the first year of study conduct, two major hospitals in the study area appeared to be non-cooperative and invitation and participation rates were less than expected. Therefore, recruitment of cases was extended by half a year to a period of three years and two additional hospitals in the catchment area of the Comprehensive Cancer Centre Eastern Netherlands were included.

To check whether invitation and participation of colon cancer cases were subject to selection, the database of the cancer registries was linked to the study database. As complete registration by the cancer registries takes place 3 to 6 months after diagnosis, linkage was conducted three months after the last case was interviewed. Surprisingly, it appeared that about one third of the 478 invited cases did not fulfil the eligibility criteria. Main reasuns for ineligibility were non-colon tumors (rectosigmoid, rectum) and secondary primaries.

Of the eligible subjects who got colon cancer during the study period, and who were treated in cooperating hospitals, $47 \%$ were invited by their surgeon; more than $50 \%$ of these were invited after the surgeon had been notified by the cancer registry. Of those invited, $72 \%$ replied, $69 \%$ filled out a short questionnaire and $60 \%$ were additionally willing to participate in the home interview. The 200 eligible participants differed significantly from the total of eligible patients only according to tumor status: subjects with Dukes' A and B tumors were overrepresented, since these less severe cases were invited more frequently by their surgeons. 


\section{Control recruitment}

To increase response of controls, efficiency of procedures and to match cases to their source population, controls were recruited using the database of the general practitioner (GP) of the case interviewed. Of the GP-mediated controls invited, 79\% replied, $75 \%$ filled out the short questionnaire, and $57 \%$ were willing to be interviewed. The 259 eligible participants did not differ with respect to age and gender from those invited, which resembled the distribution among the cases. Participants lived more frequently in urban areas and were more often privately insured than the non-participants. The proportion of privately insured (38\%) closely resembled the proportion in the general population in 1992 (32\%) according to the Dutch Central Bureau of Statistics.

To study whether the GP-mediated procedure of control recruitment did indeed increase response, but introduced some biases, demographic characteristics and dietary habits of GP controls living in urban areas $(n=249)$ were compared with an age-stratified sample $(n=301)$ drawn from municipal registries of four representative towns. Response of the urban GP-mediated controls was higher than that of the municipal controls (78\% vs. $71 \%$ ). GP-mediated and municipal controls did not differ in frequency of visiting their GP. The urban controls recruited by these procedures differed in proportion of privately insured (GP-mediated $36 \%$. municipality-mediated $57 \%$ ), in the proportion of men (54\% vs. $44 \%$ ) and in intake of fermented dairy products (in highest category of intake $29 \%$ vs. $37 \%$ ).

\section{Non-response}

With a short questionnaire brietly inquiring about dietary patterns, it was planned to gain information on habits of non-responders, i.e. those who did not participate in the interview. However, only $23 \%$ of the cases not interviewed and $42 \%$ of the nonparticipating controls completed the questionnaire. Non-participating cases who filled out the short questionnaire were more frequently female and consumed more fermented dairy products than interviewed cases. Non-participating controls who completed the short questionnaire did not differ in demographic or medical factors nor in dietary patterns. Unfortunately, firm conclusions cannot be drawn from these observations since those non-participants who completed the questionnaire may not be representative of the total of non-responders.

\section{Collection and validity of dietary intake data}

The structured dietary history questionnaire was based on the validated questionnaire used in a previous case-control study on breast cancer. The part assessing the consumption of dairy products was extended and additional crosschecks on the internal consistency of the frequency of various meal components 
with the total meal pattern were implemented.

Interviewing was conducted by seven dieticians who interviewed a similar number of cases and controls. No important differences were observed between interviewers.

Each retrospective study may be prone to recall bias, which might differ between cases and controls. As it is expected that cases may generally overestimate their dietary intake, it is very important to adjust nutrient intakes for total energy intake in the data analyses. Since the participants were unaware of the hypothesis tested and dairy products have a relatively positive health-image, it is unlikely that cases have systematically over- or underestimated their dairy product consumption.

\section{Implications}

The foregoing might have implications for internal and external validity.

Internal validity implies validity of inference for the study subjects themselves. A loss of power of $6 \%$ is due to the fact that about $30 \%$ of the orginally interviewed cases turned out not to be eligible for the study. Still the power to detect an odds ratio (OR) of 0.5 , assuming $\alpha=0.05$ two-sided and $\beta=0.1$, will be ca. $80 \%$ when 200 cases and 259 controls are included in the analyses. For reasons of efficiency, cases who were 75 years old at diagnosis and 76 years old when interviewed will be included in the study.

Moreover, since the definition of rectosigmoid might differ between clinicians and the cancer registries, analyses may be conducted including as well as excluding the 28 assumed rectosigmoid cases.

The fact that participating cases have a better prognosis than non-participants may have a positive effect on the validity of the dietary data. No association between tumor status and the consumption of fermented dairy products was observed, which implies that the inclusion of cases with a relatively better prognosis in the study is not likely to influence the results importantly.

The consumption of fermented dairy products might differ between participating and non-participating cases and between participating and non-participating controls in a different way. Although the data must be interpreted with considerable caution due to the small group of non-participating cases who filled out the short nonresponse questionnaire, the consumption of fermented dairy products may be lower for the participating cases than for the total case group. Although the difference was not significant, participating controls consumed fermented dairy products more frequently than those only filling out the non-response questionnaire. The possible selection of cases and controls will strenghten the hypothesized inverse association. As a consequence, when a significant inverse association will be observed, one should be cautious interpreting the results. 
Controls recruited via municipal registries appear to be less representative of the population at large than controls recruited via the GP of the cases. Using municipal controls might erroneously strengthen the potential inverse association.

External validity or the generalizability of the study results is associated with the internal validity of the study. Given the data presented, the internal validity of this study is thought to be appropriate. The results of the study will be applicable to less severe colon cancer cases and may be extended to more severe cases since no association was observed between Dukes' status and fermented dairy product consumption or calcium intake.

In conclusion, the results of this case-control study are not likely to be strongly influenced by selection or information bias, and the choice for GP controls rather than municipal controls has beneficially affected the validity of the study.

\section{Study population}

\section{Principles}

\section{Definition of cases and controls}

Cases were defined as subjects with newly diagnosed adenocarcinoma of the colon (ICD-0 153). Cases and controls were Dutch-speaking western Europeans, without a history of cancer (excluding non-melanoma skin cancer), who were 75 years old or younger. Persons with inflammatory bowel diseases, such as ulcerative colitis or Crohn's disease, were excluded from this study. The control group closely resembled the case group in age and gender distribution and resided in the same study area.

The study population was recruited from the central and eastern parts of the Netherlands, the catchment areas of the Comprehensive Cancer Centres Middle Netherlands and Eastern Netherlands respectively.

\section{Study size and duration}

Study size is determined by power considerations. In Table 4.1 study sizes and the related power to detect a possible association are presented. According to the literature, assuming a linear dose-response relationship between calcium and the risk of colon cancer in the United States, an intake per day of $1500 \mathrm{mg}$ in men and $1800 \mathrm{mg}$ in women may be related to a decrease in risk of $50 \%$.' An odds ratio (OR) of 0.5 between the highest and lowest quartile of intake, corresponding with an intake of more than $1500 \mathrm{mg}$ compared to less than $500 \mathrm{mg}$ per day in the 
Netherlands, can be detected with a power of $86 \%(\alpha=0.05)$ when 250 cases and 250 controls are included in the study.

Table 4.1 Study size and statistical power to detect an association. ${ }^{2}$

\begin{tabular}{lll}
\hline Cases & Controls & $\begin{array}{l}\text { Power for OR }=0.5 \\
\text { Q4 versus Q1 }\end{array}$ \\
\hline 100 & 100 & $53 \%$ \\
125 & 125 & $64 \%$ \\
150 & 150 & $68 \%$ \\
175 & 175 & $77 \%$ \\
200 & 200 & $79 \%$ \\
225 & 225 & $83 \%$ \\
250 & 250 & $86 \%$ \\
\hline
\end{tabular}

$\alpha=5 \%$ (one-sided).

Based on cancer registry incidence data of 1985-1989, about 200 cases with adenocarcinoma of the colon, meeting the inclusion criteria, can be expected annually in the catchment area of the Comprehensive Cancer Center Middle Netherlands. Given a $80 \%$ cooperation rate of surgeons, a $80 \%$ invitation rate and a $80 \%$ response rate, which were estimated from a previous case-control study on breast cancer in the Netherlands, ${ }^{3}$ a study period of two and half years was considered to yield the required number of subjects.

The actual recruitment of cases in time is presented in Figure 4.1. In August 1990, recruitment of cases started in 13 of the 14 hospitals in the central part of the Netherlands. Since case recruitment started slowly and organizational difficulties were experienced in two major hospitals, data collection was extended to two important hospitals in the region of the Comprehensive Cancer Registry Eastern Netherlands by July 1991. The cooperation of surgeons ( $81 \%$ ) was comparable to the previous breast cancer study, but the actual invitation rate of cases was far below the estimated $80 \%$ : $47 \%$ of the eligible cases were invited (see 'recruitment of cases'). The former figure was probably too optimistic, since at the time the breast cancer study was conducted, it could not be based on a formal cancer registry yet. The lower response of the invited cases (60\% as compared to $80 \%$ ) (see 'recruitment of cases') may be due to the more direct relationship between colon cancer and dietary patterns or the higher mean age of the participants.

Thus, to be able to include 250 cases in the study with these invitation and response rates, the recruitment period was extended to three years. 


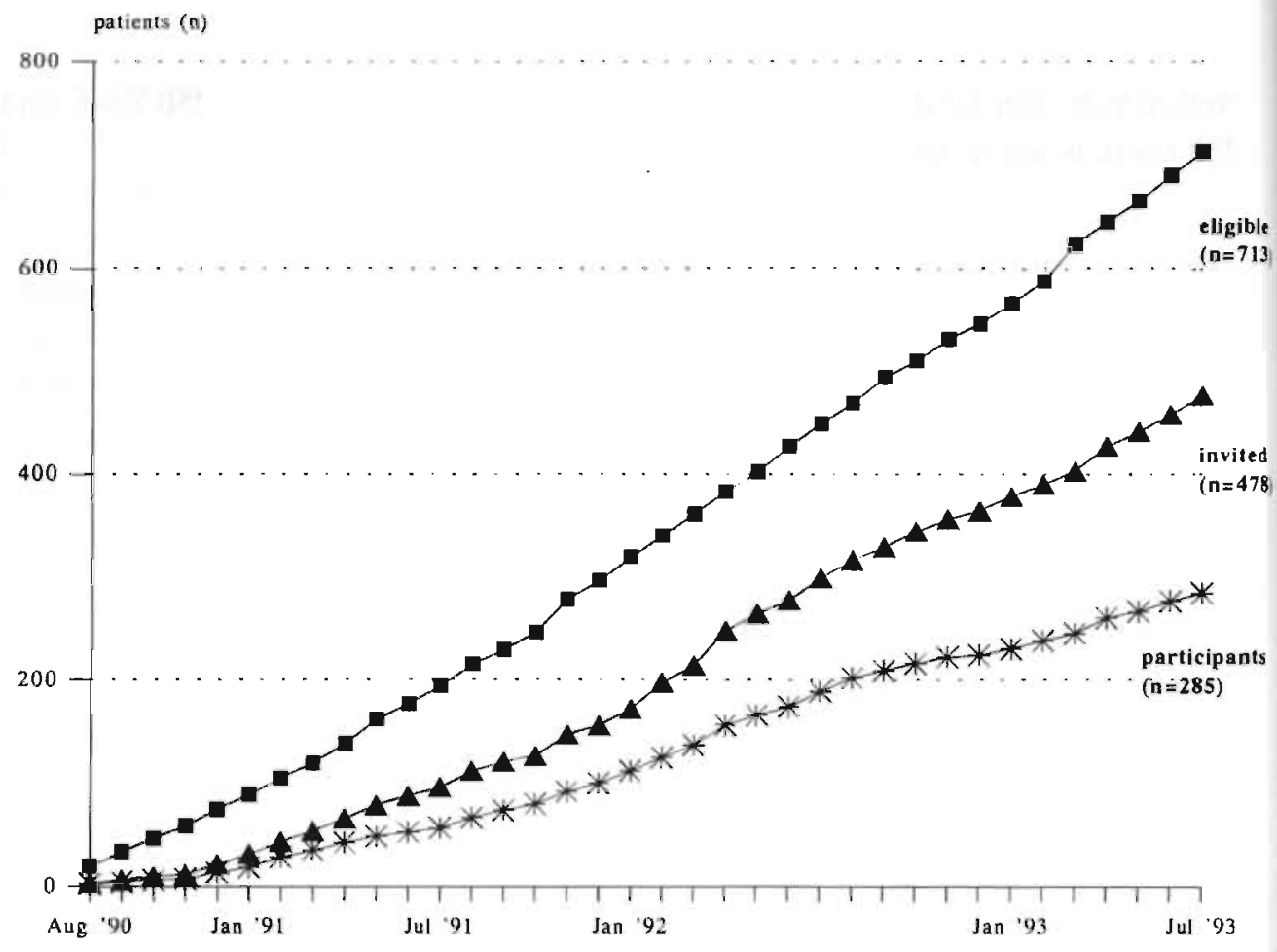

Figure 4.1 Recruitment of cases in time.

\section{Recruitment of cases}

\section{Procedures of case recruitment}

To be able to approach as many eligible cases as possible, two complementary procedures of case recruitment were applied (Figure 4.2).

According to the first procedure, surgeons identified patients meeting the eligibility eriteria, and gave them a letter of invitation during their stay in the hospital, shortly after diagnosis. All cases seen by the surgeon were notified to the researchers; demographic characteristics (gender, date of birth and place of residence) were reported. If the patient was not invited for medical or psychological reasons, or because the patient did not match the inclusion criteria, the reason for non-invitation was recorded.

The second recruitment procedure was meant to identify cases possibly missed by the first procedure because they were not invited by the surgeon. Demographic data frum the list of cases notified to the researchers were linked to the database of the cancer registries involved. If an eligible case appeared not to have been invited in the first procedure, the cancer registries notified the surgeons and asked to mail the letter of invitation to the patient's home address or to invite the patient during the first check up. 


\section{Procedure 1}

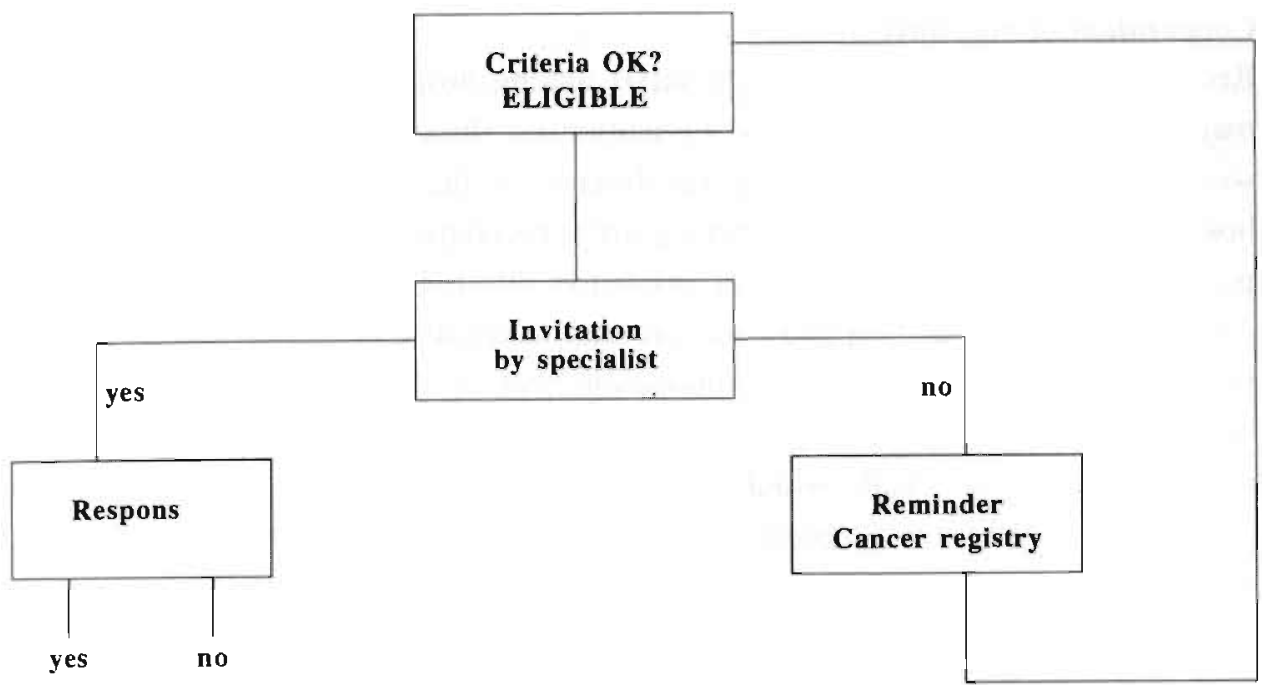

Figure 4.2 Recruitment of cases by two complementary procedures.

The cooperation of the cancer registry in case recruitment appeared to be crucial as $50 \%$ of those invited and $49 \%$ of the eligible interviewed cases were recruited through this procedure (Figure 4.3).

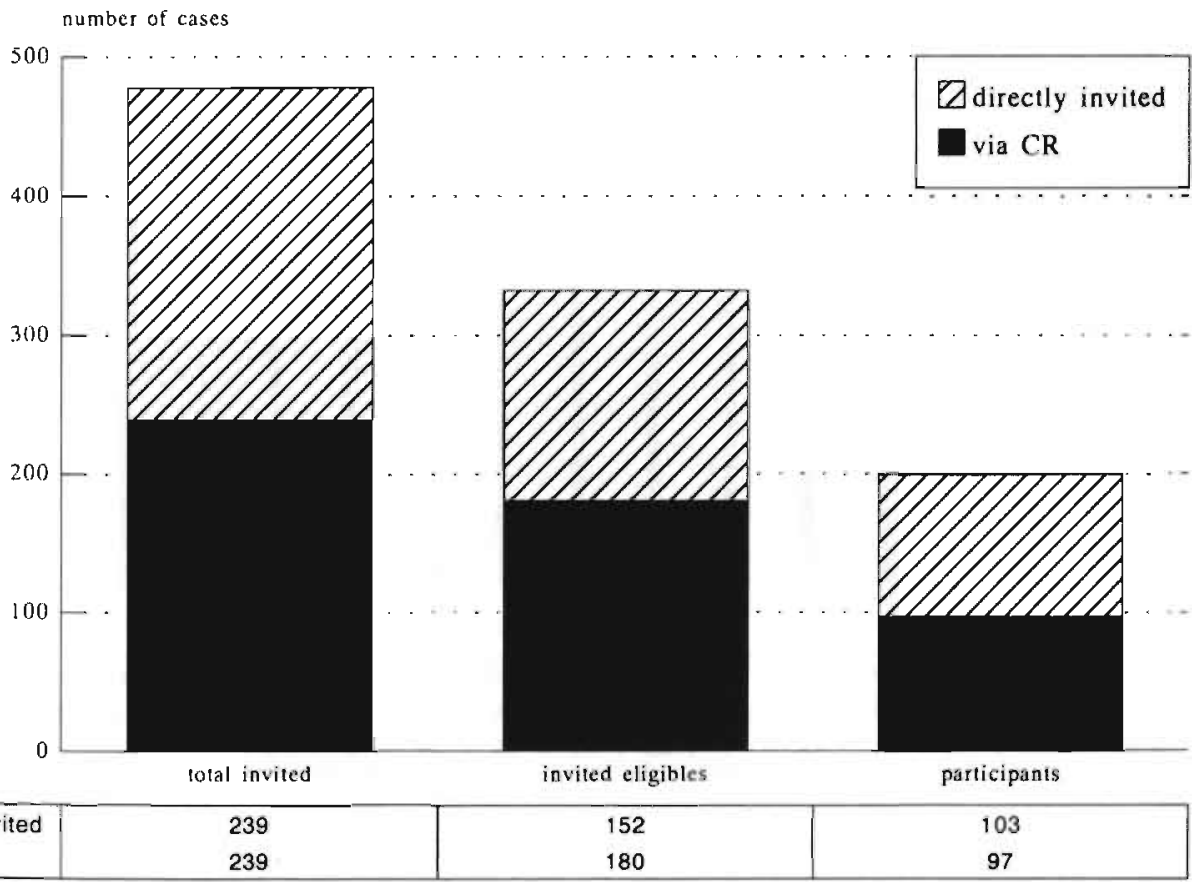

Figure 4.3 Invitation and participation of cases according to recruitment procedure: by direct invitation (procedure 1) or via Cancer Registry (procedure 2). 


\section{Cooperation of hospitals}

Recruitment procedures appeared to differ among hospitals. In some hospitals, the majority of the cases were asked to participate directly after surgery when they were still in the hospital, without interference of the cancer registry, while other hospitals relied mainly on the cancer registry procedure. Besides these differences in procedures used, the actual rate of invitation differed among hospitals. In Figure 4.4. the cooperating hospitals are ordered according to number invited as a proportion of those eligible. The invitation rates in the different hospitals varied between $78 \%$ and $6 \%$. Figure 4.4 shows that participation rates of cases varied among hospitals as well, which might be explained by the different personal approaches used by the surgeons and the different recruitment procedures used. Of the eligible cases who were invited directly by the surgeon $68 \%(103 / 152)$ participated, while the participation rate was $54 \%(97 / 180)$ for the cases invited after interference of the cancer registry (Figure 4.3).

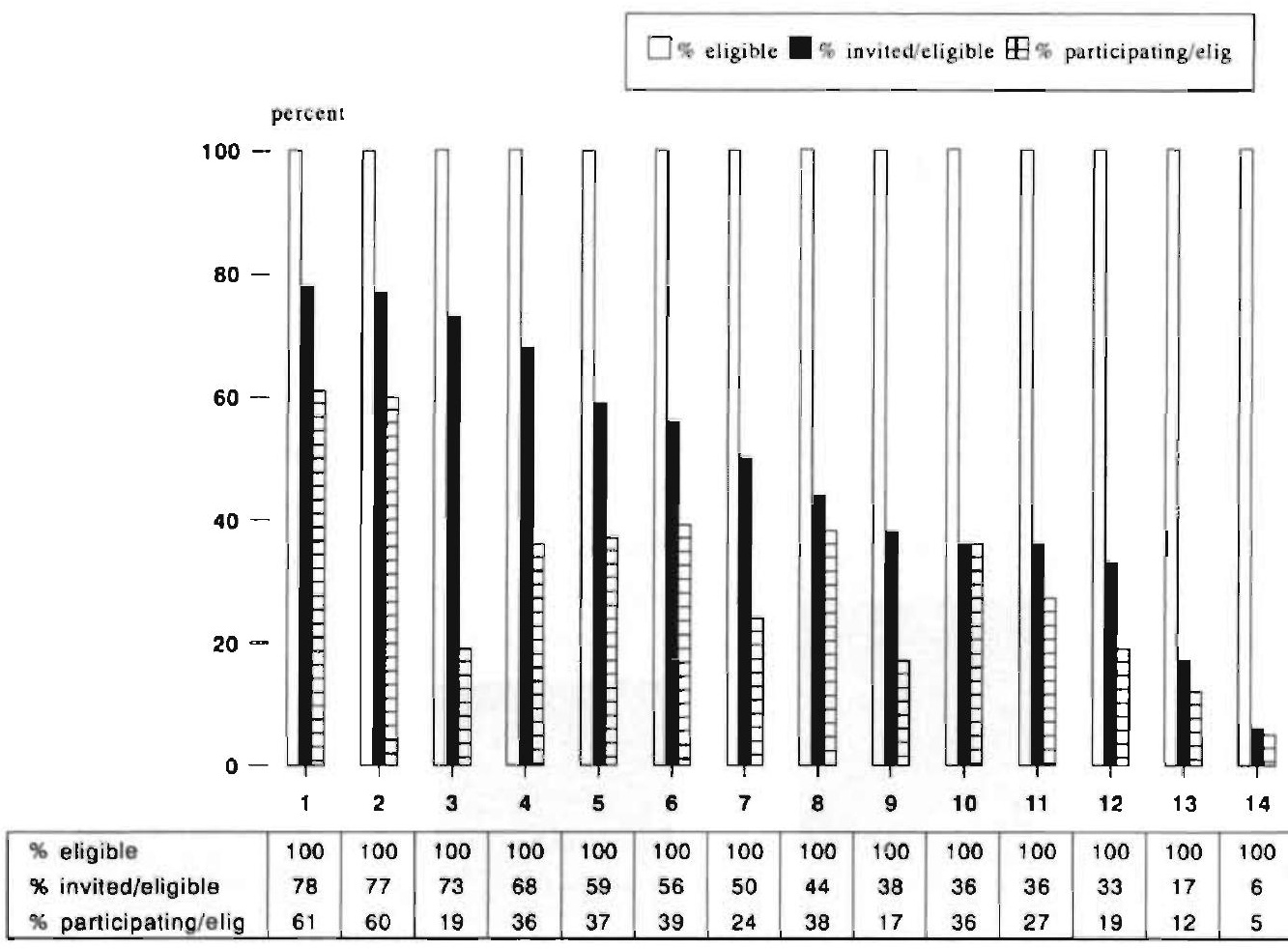

Figure 4.4 Recruitment per hospital.

Eligibility of invited cases

Figure 4.5 presents the relation between the study database and the cancer registry 
data, for different stages in recruitment. From August 1990 to August 1993, 2064 colon cancer cases were recorded by the Comprehensive Cancer Centres Middle and Eastern Netherlands (Figure 4.5), of which 1412 were seen in cooperating hospitals. Of these 1412 colon cancer patients, $677(48 \%)$ met the inclusion criteria known by the cancer registries (adenocarcinoma, 75 years or younger, no previous tumors), and did not decease before they could be invited. Of these 677 eligible cases, 445 (66\%) were reported to the research team during the study. During the recruitment period, surgeons notified another 47 cases to the research team of which 36 seemed to be eligible; these cases however did not appear in the cancer registry database. This might be mainly due to the fact that comparison with the cancer registry database took place three months after the last interview, while final registration lasts until six months after surgery.

These facts explain why the number of participants (Figure 4.1) exceeds the number of interviewed eligible cases $(n=200)$ in Figure 4.5.

During three years of recruitment, 478 patients were invited (Figure 4.1 and 4.3). Unexpectedly, for the researchers as well as the cancer registries, $146(31 \%)$ of these cases did not meet the eligibility criteria. Most of these ineligibles were identified through linkage to the cancer registries (87\%), whereas 19 cases (13\%) were found to be ineligible during the home interview. The main reasons for ineligibility were the site of the tumor (according to the cancer registries: 43 rectosigmoid, 41 rectum, 3 other sites outside the large bowel) and the fact that 36 colon tumors were secondary primaries. Further ineligibility resulted from the malignancy grade or morphology of the tumor (7 tumors in situ, 4 metastasis of other primaries, 2 non-adenomatous) or was related to non-tumor related criteria (7 cases older than 75, 1 did not speak Dutch, 2 were not western Europeans and 5 deceased before the interview could take place). As final registration of cases by the cancer registry, including the more precise localization of the tumor, takes place six months after surgery, these types of errors are difficult to prevent. After all, to diminish recall bias and the number of deceased subjects, cases should have been interviewed as soon as possible after diagnosis, which was before final registration could take place.

It should be realized that the fact that ineligible cases were invited implies that ineligible cases participated in the interview $(n=85)$, and the decision to exclude them from data analysis would result in a loss of statistical power.

\section{Response and participation of cases}

All invited cases were asked to return a reply form on which they could indicate their (un)willingness to participate in the detailed interview at home (see 'Collection and validity of the data'). The reply form included a short questionnaire inquiring 
about dietary patterns. Non-participants and participants in the home interview were asked to complete the questionnaire to be. able to define the non-response (see 'indicators of non-response').

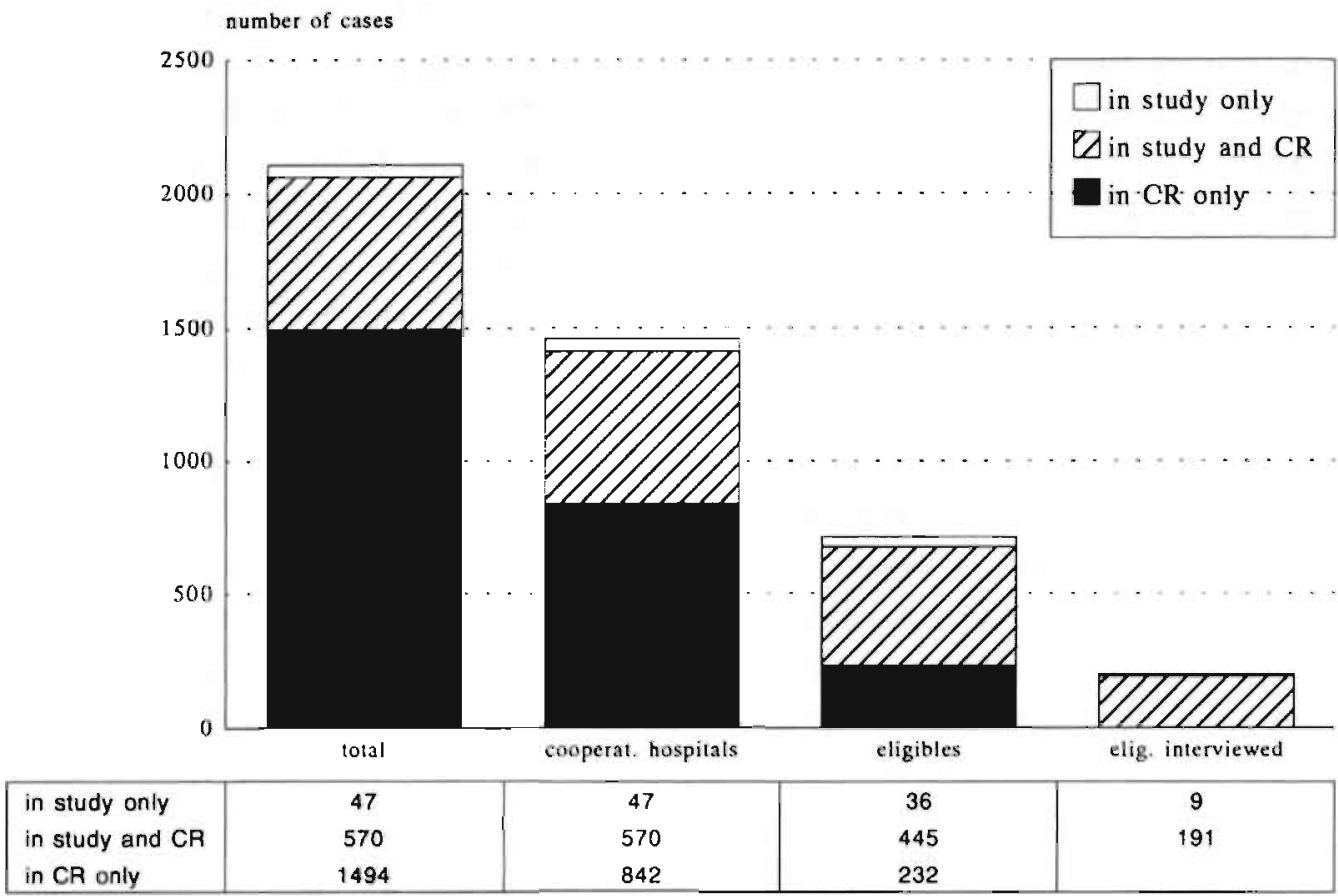

Figure 4.5 Number of colon cancer cases in the study and in the databases of the cancer registries (CR).

If an invited case replied to be willing to participate, the home interview took place three to six months after diagnosis. Of the 322 invited eligibles, 240 (72\%) returned the reply form, $230(69 \%)$ completed the short questionnaire, while 200 $(60 \%)$ participated in the interview (Table 4.2).

\section{Determinants of invitation and participation}

With the exception of cases under 40 who were invited least frequently, numbers of eligible colon cancer cases invited were inversely related to age (Table 4.2, first column). Patients with Dukes' A or B tumors and those who underwent only an operation were more likely to be invited than patients with Dukes' C or D tumors or those who underwent a therapy other than an operation or had additional therapy (e.g. radiation, chemotherapy). Invitation was not related to gender, degree of urbanization (urban or rural) and tumor site (left- or right-sided) (Table 4.2). 
Table 4.2 Response rates, stratified according to demographic variables, of eligible colon cancer cases $(\mathrm{n}=713)$ * $^{*}$

$\begin{array}{llll}\begin{array}{l}\text { Invited } \\ (\%)(n=332)\end{array} & \begin{array}{l}\text { Replied }^{2} \\ (\%)\end{array} & \begin{array}{l}\text { Filled out } \\ \text { short }\end{array} & \begin{array}{l}\text { Participated in } \\ \text { interview }\end{array} \\ & (n=240) & \begin{array}{l}\text { questionnaire } \\ (\%)\end{array} & (\%=230)\end{array}$

\begin{tabular}{lllll}
\hline Overall response & 47 & 72 & 96 & 87 \\
\hline
\end{tabular}

\section{Demographic variables}

$\begin{array}{crrrr}\text { age }<40 \text { years } & 39 & 74 & 100 & 82 \\ 40-49 & 54 & 82 & 100 & 86 \\ 50-59 & 49 & 77 & 98 & 92 \\ 60-69 & 48 & 71 & 94 & 86 \\ 69-75 & 43 & 66 & 93 & 87 \\ \text { gender male } & 49 & 72 & 96 & 93 \\ \text { female } & 44 & 73 & 96 & 81^{*} \\ \text { regionurban } & 88 & 69 & 97 & 86 \\ \text { rural } & 85 & 80 & 96 & 89 \\ \text { unknown } & 2 & 20 & 0 & 0\end{array}$

Medical factors

tumor status

$\begin{array}{lllll}\text { Dukes' A and B } & 58 & 76 & 96 & 89 \\ \text { Dukes C and D } & 45^{*} & 73 & 95 & 87 \\ \text { unknown } & 31 & 60 & 97 & 81\end{array}$

therapy (\%)

\begin{tabular}{lrrrr}
$\begin{array}{l}\text { no therapy } \\
\text { operation } \\
\text { other (additional) }\end{array}$ & 0 & 0 & 0 & 0 \\
therapies & 54 & 72 & 95 & 87 \\
unknowns & $43^{*}$ & 80 & 100 & 91 \\
r site $(\%)$ & 32 & 67 & 97 & 82 \\
right-sided & & & & \\
left-sided & 50 & 70 & 94 & 91 \\
unknowns & 47 & 75 & 97 & 84 \\
\hline
\end{tabular}

1 invited as a percentage of eligible.

${ }^{2}$ replied as a percentage of invited.

3 short questionnaire as a percentage of replied.

${ }^{4}$ interview as a percentage of short questionnaire.

$s$ the category 'unknown' was not included in analyses of heterogeneity.

* heterogeneily in response rate $(p<0.05)$.

Additionally, Table 4.2 presents the response rates by demographic and medical characteristics for those eligibles who returned the reply form (second column), those who completed the short questionnaire (third column) and those who eventually participated in the interview at home (fourth column). 
Response rates were somewhat higher among younger persons (except for those under 40 years) and among those living in rural areas.

Although response rates and the willingness to fill out the short 'non-response' questionnaire did not differ between genders, men were more inclined to participate in the interview.

Table 4.3 Distribution of demographic and medical characteristics of total eligible colon cancer cases and those eligible cases participating in the home interview.

\begin{tabular}{lll}
\hline & \multicolumn{2}{c}{ Colon cancer cases } \\
\cline { 2 - 3 } Variables & $\begin{array}{l}\text { Total eligible } \\
(\mathrm{n}=713)\end{array}$ & $\begin{array}{l}\text { Participants in } \\
\text { home interview } \\
\end{array}$ \\
& & $(\mathrm{n}=200)$ \\
\hline
\end{tabular}

\section{Demographic variables}

$\begin{array}{crr}\text { age (\%) }<40 \text { years } & 8 & 7 \\ 40-49 & 9 & 12 \\ 50-59 & 19 & 22 \\ 60-69 & 36 & 36 \\ 69-76 & 29 & 24 \\ \text { gender (\% male) } & 51 & 57 \\ \text { region (\%)' } & & 60 \\ \text { urban } & 64 & 40 \\ \text { rural } & 36 & \\ \text { Medical factors } & & 64 \\ \text { tumor status (\%) }{ }^{2} & & 36^{*} \\ \text { Dukes' A and B } & 57 & 0 \\ \text { Dukes' C and D } & 43 & 82 \\ \text { therapy (\%) } & & 18 \\ \text { no therapy } & 2 & 49 \\ \text { operation only } & & \\ \text { other (additional) therapies } & 80 & 51\end{array}$

* differs from non-participants ( $53 \% ; \mathrm{p}<0.05$ ), the category 'unknown' is not included in the analyses of heterogeneity.

unknown of total eligible: $47 \%$.

unknown $28 \%$ and $16 \%$ respectively.

unknown $23 \%$ and $14 \%$ respectively.

4 unknown $12 \%$ and $9 \%$ respectively.

Tumor status, therapies and tumor site were not appreciably related to response rates. Of course, one should realize that this may simply reflect the fact that the surgeons had already limited their invitations to subjects who were in fair condition 
and able to participate.

For interpreting the relevance of the separate stages in selection identified above, the initial and final distribution of demographic and medical characteristics is of interest. The more frequent participation of less severe cases being the only exception, the distribution of demographic and medical characteristics of the final eligible cases participating in the interview did not differ markedly from the initial eligibles (Table 4.3).

This implies that, relatively, more healthy cases participated in the interview. However, since illness, radiotherapy and chemotherapy might influence dietary patterns and thus might hamper the recall of habitual diet, excluding cases with a worse prognosis is likely to favour the quality of the interview data.

Of course, the crucial issue for inference from the case-control study is whether the distribution of the exposures of interest, fermented milk consumption and calcium intake, is altered by the subsequent selection steps. Although this cannot be studied throughout all subsequent steps, we intended to obtain limited dietary data from all cases using a short questionnaire. A similar attempt was made among nonparticipating controls. Results of both groups are described in 'Indicators of nonresponse'.

\section{Implications of case recruitment}

Invitation and participation rates estimated in the planning of the study differed from those actually observed; invitation and participation were both estimated to be $80 \%$ and turned out to be $47 \%$ and $60 \%$ respectively. Therefore the period in which case recruitment took place had to be extended from $2 \frac{1 / 2}{2}$ to 3 years and two hospitals in the east part of the Netherlands were included.

Surprisingly, about one third of the interviewed cases did not meet the inclusion criteria of the study. Instead of the planned power of $86 \%$, an odds ratio of $50 \%$ can be detected with a power of about $80 \%$ when 200 cases and 250 controls are included in the study. For reasons of efficiency, cases who were 75 years old at diagnosis and 76 years old when interviewed, were included in the study. Moreover, since the definition of rectosigmoid might differ between clinicians and the cancer registries, ${ }^{4}$ analyses were conducted including as well as excluding the 28 assumed rectosigmoid cases.

Whether a patient was invited was related 10 tumor status and therapy. Participating cases did not differ significantly in demographic factors from all cases who could have been included in the study. As a result of differences in invitation rates, participants had more Dukes` A or B tumors than the total group of eligibles, which might benefit the quality of the exposure data. More severe cases might have changed their diet as a result of the disease, which might make it more difficult to 
recall previous dictary patterns. Iurthermore, nausea from chemotherapy, which occurs more frequently among patients with Dukes' C and D tumors, might influence both appetite and the ability to talk about food for two hours or more.

\section{Recruitment of controls}

\section{Rationale}

In this study controls were sampled via the general practitioner of the interviewed case. This procedure was used to increase response rate and efficiency and to ensure a justifiable link to the source population. As observed in a previous case-control study on breast cancer, sampling of controls from municipal population registries has the disadvantage of relatively low response rates (55\% among women). Additionally, the latter sampling method has a practical disadvantage since the source population of the cases is difficult to define before cases are recruited; this is especially true since not all hospitals in a given area are willing or able to cooperate in a study. Furthermore, the increased awareness of privacy regulations introduces practical difficulties in sampling from municipal registries.

To investigate the advantages and disadvantages of this GP-mediated procedure as compared to the municipal registry method, a age- and gender-stratified sample was recruited from municipal registries of four representative towns.

\section{Procedures for control recruitment}

Three persons of the same gender and approximately the same age ( \pm 5 years) as the case were randomly selected by the general practitioner's of the case. For each case, the GP received a standardized form with three-letter strings, randomly obtained from the local telephone directory to initiate the search for controls in his or her own databasc; for each string, the first subject who matched the eligible criteria was send a standard letter of invitation, including a reply form to the investigator. After two weeks, each non-responder received a reminding letter. The first or second responder was included in the study.

Since GPs often have separate databases for privately and non-privately insured patients, they were asked to draw two non-privately insured and one privately insured patients from their database(s), which resembles the ratio in the general population.

\section{Cooperation of general practitioners}

Of the 264 approached general practitioners (GPs), 67\% were willing to cooperate. If the GP refused cooperation a gender-matched control who resembled the patient as much as possible concerning age, gender and urbanization grade and region was 
selected from controls sampled by other GPs. If not available (5\%), a control sampled from the municipal registry of the town involved was chosen.

GPs were asked to complete a short questionnaire inquiring about the way the three control subjects were sampled; $100 \%$ replied and reported that they had followed the sampling instructions.

\section{Cooperation of municipal registries}

The municipal registries of four suburban and two urban towns were invited to draw a age-stratified sample of 50 to 100 inhabitants. The required number of controls to be sampled from each five-year age category was calculated on the basis of colon cancer incidence figures.

Each registry was willing to cooperate, but for budgetary reasons it was decided to draw samples from three suburban and one urban town only. For privacy reasons, the urban registry conducted the mailing themselves.

\section{Participation of GP-mediated controls}

Of the 520 GP-mediated controls invited, $79 \%$ returned the reply form (60\% before a reminding letter was sent), while $75 \%$ filled out the short questionnaire and $57 \%$ was willing to participate in the interview. Age was related to response: persons under 40 where more inclined to participate in the interview (Table 4.4). Men and women did not differ in readiness to fill out the questionnaire, although women tended to be more inclined to participate in the interview. Response rates were higher in urban regions. From the $294 \mathrm{GP}$-mediated controls who were willing to be interviewed, a subsample was selected which resembled the case-population as closely as possible according to age, gender, region and urbanisation grade.

In total, 266 controls were interviewed. Of those interviewed, five did not meet the inclusion criteria ( 3 not western European, 1 previous cancer and 1 Crohn's disease) and one interview was not completed.

Of the 259 controls participating in the interview $95 \%$ were recruited through the GP-mediated procedure, while $5 \%$ were sampled from municipal registries.

The age and gender distribution of the 259 eligible participating controls resembled closely the distribution of those invited (Table 4.5). The participants were likely to be more urban citizens and were more often privately insured. In multivariate logistic regression analysis, with participation being the dependent variable, both urbanization grade and health insurance contributed significantly to the model.

The proportion of privately insured controls closely resembles the proportion in the general population, which is about one third. 
Table 4.4 Response rates, stratified according to demographic variables, of invited population controls $(\mathrm{n}=520)^{\mathrm{s}}$

\begin{tabular}{|c|c|c|c|c|c|}
\hline & & $\begin{array}{l}\text { Replied }^{1}(\%) \\
(n=409)\end{array}$ & $\begin{array}{l}\text { Filled out } \\
\text { short } \\
\text { questionnaire } \\
(\%)(n=389)\end{array}$ & $\begin{array}{l}\text { Willing to } \\
\text { participate in } \\
\text { interview }{ }^{3} \\
(\%)(n=294)\end{array}$ & $\begin{array}{l}\text { Participated } \\
\text { in interview } \\
(\%) \\
(n=259)^{s s}\end{array}$ \\
\hline \multicolumn{2}{|c|}{ Overall response (\%) } & 79 & 95 & 76 & 88 \\
\hline \multicolumn{6}{|c|}{ Demographic variables } \\
\hline \multirow[t]{5}{*}{ age } & $<40$ years & 89 & 96 & 91 & 60 \\
\hline & $40-49$ & 73 & 92 & 72 & 90 \\
\hline & $50-59$ & 77 & 98 & 79 & 86 \\
\hline & $60-69$ & 79 & 95 & 75 & 95 \\
\hline & $>69$ & 82 & 94 & $70^{*}$ & $88^{*}$ \\
\hline \multirow[t]{2}{*}{ gender } & male & 78 & 95 & 74 & 88 \\
\hline & female & 80 & 95 & 77 & 88 \\
\hline \multirow[t]{2}{*}{ region } & urban & 82 & 94 & 77 & 90 \\
\hline & rural & $73 *$ & 97 & 74 & 85 \\
\hline \multicolumn{6}{|c|}{ health insurance } \\
\hline & private & 82 & 95 & 79 & 90 \\
\hline & non-private & 76 & 95 & 74 & 88 \\
\hline & unknown sss & 100 & 96 & 86 & 100 \\
\hline
\end{tabular}

heterogeneity in response $(p<0.05)$.

replied as a percentage of invited.

short questionnaire as a percentage of replied.

willing to participate as a percentage of short questionnaire.

participated as a percentage of willing to participate.

recruited via general practitioners.

95\% recruited via general practioners, $5 \%$ sampled from municipal registries.

category 'unknown' not included in analyses of heterogeneity.

\section{Municipal and GP-mediated controls}

Of the 424 invited controls sampled from municipal registries, $71 \%$ filled out the short questionnaire as compared to $76 \%$ of the suburban and urban GP-mediated controls. Table 4.6 presents the characteristics of municipal controls as compared to suburban and urban GP-mediated controls. Selection might have occurred if GPs did not adhere strictly to the protocol and were more prone to invite persons who regularly visit their doctor. Consistent with the reported adherence to the sampling protocol (see "Cooperation of general practitioners"), the frequency of visits was similar for GP-mediated and municipal controls (22\% versus $25 \%$ more than twice a year). Age, body mass index, gastro-intestinal complaints, changes of diet because of gastro-intestinal complaints, the consumption of whole-wheat bread, meat and unfermented dairy products did not differ appreciably between the groups of 
controls recruited via these different procedures. Men tended to be more willing to cooperate when invited by their GP. Municipal controls who filled out the questionnaire were more likely to be privately insured; the proportion of private insured $(57 \%)$ greatly exceeded the proportion in the general population (33\%).

Table 4.5 Distribution of demographic characteristics of invited population controls ${ }^{5}$ and the actual eligible population controls participating in the home interview.

Invited $(\mathrm{n}=520)$

Actual participants in interview $(\mathrm{n}=259)$

Demographic variables

age $(\%)<40$ years

$40-49$

5

5

50-59

12

11

60-69

25

26

$69-75$

38

40

$20 \quad 19$

gender (\% male)

54

53

region (\% urban)

62

$66^{*}$

health insurance (\% private)

34

$38^{* *}$

* differs from non-participants $(58 \% ; p=0.05)$.

** differs from non-participants $(30 \% ; p=0.05)$.

s $95 \%$ recruited via the GP-mediated procedure, $5 \%$ sampled from municipal registries.

Fermented dairy products were consumed more frequently by the municipal controls. After stratification for health insurance this difference was no longer important. However, in multivariate analyses with type of control (GP-mediated or municipal) being the dependent variable, gender, insurance and the consumption of fermented dairy products contributed independently.

In summary, comparing the two procedures of control recruitment, the GPmediated procedure has two advantages: response of invited controls is slightly higher and, more importantly, the distribution of privately insured people is comparable to that in the general population. Since GPs adhered to the protocol and the numbers of GP visits are similar for the controls recruited by both procedures, no important selection of controls does seem to occur using the GP databases. It can be concluded that the GP-mediated procedure is a reliable method for control recruitment and that it might be preferable to the municipality method used in previous studies.

\section{Implications of control recruitment}

The participating controls were similar to those invited in age and gender, which implies a close resemblance to the case group. Participating controls lived more frequently in urban areas and were more often privately insured than the total group of controls invited. As this might imply a higher socio-economic status of the 
participating controls, odds ratios were adjusted for socio-economic level, in data analysis.

As anticipated on, the response of urban GP-mediated controls was higher than that of the municipal controls (Table 4.6). The controls recruited by these two procedures differed in the proportion of men, proportion of privately insured people and the consumption of fermented dairy products. According to the proportion of men and those privately insured, the GP-mediated controls appear to resemble the general population more closely.

Table 4.6 Characteristics of (sub)urban population controls recruited via different procedures who completed the short questionnaire.

\begin{tabular}{|c|c|c|}
\hline \multirow[t]{2}{*}{ Variables } & \multicolumn{2}{|c|}{ Recruitment procedure } \\
\hline & $\begin{array}{l}\text { via general } \\
\text { practitioner } \\
(\mathrm{n}=249)\end{array}$ & $\begin{array}{l}\text { via population } \\
\text { registry } \\
(n=301)\end{array}$ \\
\hline \multicolumn{3}{|l|}{ Response } \\
\hline completc refusers (\%) & 18 & 26 \\
\hline short questionnaire (\%) & 78 & 71 \\
\hline \multicolumn{3}{|l|}{ Demographic variables } \\
\hline age (ycars, mean $\pm S D)$ & $62 \pm 10$ & $63 \pm 10$ \\
\hline gender ( $\%$ male) & 54 & 44 \\
\hline health insurance (\% private) $)^{5}$ & 36 & 57 \\
\hline \multicolumn{3}{|l|}{ Health indicators } \\
\hline body mass index (mean $\pm S D$ ) & $25 \pm 3$ & $25 \pm 4$ \\
\hline $\begin{array}{l}\text { visits to general practitioner } \\
(\% \text { more than twice a year) })^{\text {ss }}\end{array}$ & 22 & 25 \\
\hline gastro-intestinal complaints (\% yes) & 17 & 16 \\
\hline $\begin{array}{l}\text { changes in diet because of } \\
\text { gastro-intestinal complaints (\% yes) }\end{array}$ & 5 & 9 \\
\hline \multicolumn{3}{|l|}{ Dietary habits } \\
\hline meat (\% every day) & 47 & 50 \\
\hline whole-wheat bread ( $\%$ more than 5 slices per day) & 16 & 17 \\
\hline dairy products ( $\%$ in highest category) & 32 & 40 \\
\hline fermented dairy products ( $\%$ in highest category) & 29 & $37^{*}$ \\
\hline
\end{tabular}

\section{Indicators of non-response}

The short 'non-response' questionnaire was completed by each case and control participating in the home interview and by only 30 of 122 non-participating cases and 95 of 226 controls not willing to participate. Thus, only a small fraction of the 
non-participants completed the questionnaire. Of the 30 eligible non-participating cases, 13 refused participation for medical or psychological reasons, 10 did not want to participate for unknown reasons, while 7 did not fill out the reply form at all. Reasons for non-participation for the other 302 non-participants remain unknown.

Table 4.7 Health indicators and dietary habits of those eligible colon cancer cases and controls who only filled out the short questionnaire and those additionally participating in the home interview.

\begin{tabular}{|c|c|c|c|c|}
\hline \multirow{2}{*}{ Variables } & \multicolumn{2}{|c|}{ Colon cancer cases } & \multicolumn{2}{|c|}{ Population controls } \\
\hline & $\begin{array}{l}\text { short } \\
\text { questionnaire } \\
\text { only }(n=30)\end{array}$ & $\begin{array}{l}\text { home } \\
\text { interview } \\
(n=200)\end{array}$ & $\begin{array}{l}\text { short } \\
\text { questionnaire } \\
\text { only }(n=95)\end{array}$ & $\begin{array}{l}\text { home } \\
\text { interview } \\
(n=259)\end{array}$ \\
\hline \multicolumn{5}{|l|}{ Health indicators } \\
\hline body mass index (mean $\pm S D$ ) & $23 \pm 4$ & $25 \pm 4$ & $25 \pm 3$ & $26 \pm 4$ \\
\hline $\begin{array}{l}\text { gastro-intestinal complaints ( } \% \\
\text { yes) }\end{array}$ & 37 & 32 & 18 & 16 \\
\hline $\begin{array}{l}\text { dietary changes because of gastro- } \\
\text { intestinal complaints (\% yes) }\end{array}$ & 17 & 9 & 6 & 9 \\
\hline \multicolumn{5}{|l|}{ Dielary habils } \\
\hline meat ( $\%$ every day) & 57 & 62 & 52 & 45 \\
\hline $\begin{array}{l}\text { whole-wheat bread (\% more than } \\
5 \text { slices a day) }\end{array}$ & 7 & 24 & 17 & 19 \\
\hline $\begin{array}{l}\text { dairy products* }(\% \text { highest } \\
\text { category) }\end{array}$ & 40 & 31 & 40 & 35 \\
\hline $\begin{array}{l}\text { fermented milk (\% highest } \\
\text { category) }\end{array}$ & 53 & $29^{\circ}$ & 24 & 30 \\
\hline
\end{tabular}

Of the 95 non-participating controls 1 deceased, 4 refused participation for medical reasons, 6 replied not to have time to participate, while 79 did not give a reason and 13 did not fill out the reply form. For the other 131 non-participants the reasons for non-participation remain unknown as well.

Thus, it remains unknown to what extent the non-participants who filled out the short questionnaire are representative of the total group of non-participants as far as diet is concerned. Nevertheless, in the absence of other information, the above comparison may suggest the direction of a potential selection in participation.

Table 4.7 presents the distribution of health indicators and relevant dietary habits for those eligibles interviewed (200 cases and 259 controls) compared to those who only filled out the short questionnaire. 
Cases with gastro-intestinal complaints and those who said they had changed their diet because of these complaints participated less frequently in the interview, however this difference was not statistically significant (Table 4.7). Body mass index, meat consumption and the use of dairy products were not strongly related to participation in cases and controls, while case participants ate more whole-wheat bread and less fermented dairy products (Table 4.7). Besides chance, these differences might be explained by a higher socio-economic status of the participating cases or by the fact that more male cases participated in the interview. In data analysis, odds ratios were adjusted for gender and indicators of socioeconomic status.

The way in which the above findings bias study results depends not only on cases, but also on the potential exposure-related selection among controls. Cases participating in the interview consumed less fermented dairy products than the eligible cases. Since, participating controls consumed fermented dairy products more frequently, the odds ratio calculated from the data may be stronger than the underlying true odds ratio.

\subsection{Collection and validity of the data}

Data collection involved a short questionnaire, a home interview and collection of toenail clippings.

\section{Short questionnaire}

The short questionnaire was enclosed in the letter of invitation. This questionnaire inquired about major dietary patterns and life-style variables of interest. The objective of this short inquiry was to be able to compare those willing to participate in the home interview with those not willing and thus to investigate if a certain selection was introduced by non-response to the request for a home interview. The same questionnaire was used to compare controls recruited by the GP-mediated method and the municipal registry procedure.

\section{Home interview}

Participating cases and controls were interviewed at their homes by one of seven trained dieticians. The questionnaire consisted of a dietary history part and questions considering life-style, medical history and family history of colorectal cancer. The home interview took about three hours per participant, two hours of which were taken by the dietary history part.

The interview started with questions regarding special dietary regimens (e.g. vegetarianism), diets, gastro-intestinal complaints and related dietary changes. 
It continued with a structured dietary history part inquiring about the consumption of 289 food items from 19 food groups consumed in the preceding year. For cases the year preceding complaints or diagnosis was asked for. The hierarchically structured questionnaire was divided into five sections corresponding with the national pattern and starting with the most intensive part: the main meal (appetizers, main dishes), followed by breakfast and lunch, desserts, (non)alcoholic drinks and snacks. To be able to estimate serving sizes, frequently used household utensils and cups were measured.

Additionally, for products of special interest to this study, changes in the habitual use as compared to five years earlier were asked for.

At the end of the interview, questions related to life-style (e.g. supplement use, smoking habits, sunlight exposure) were asked together with questions on previous or current illnesses, previous or current use of medicin and family history of colorectal cancer. Furthermore, the participant was weighed.

To account for seasonal variation in food habits, cases and controls were interviewed in the same season. To account for differences between interviewers, each interviewer visited a similar number of cases and controls.

Food items were coded according to the Dutch National Food Table. ${ }^{5}$ To minimize errors, the dietary history questionnaire was entered into the computer using a specially designed computer program which included range-checks and cross-checks. For each food item default values for frequency of use, number of servings, serving sizes and food code were pre-coded and could be skipped, copied or changed when a different value was required. Checks on the internal consistency of the frequency of consumption of various meal components with the total meal pattern were conducted. When frequencies did not match, a correction factor was automatically calculated and added to each item in the data file.

\section{Alterations of the questionnaire during the interview period}

Besides the main hypothesis, other issues were planned to be studied, which sometimes needed an extention or alteration of the original questionnaire. Not all of the new additions turned out to be successful. Especially with the assessment of height, physical activity and the combined consumption of fermented dairy products and nitrate-rich foods practical difficulties were encountered.

In the beginning of the study, both height and weight of the participants were determined. However, measuring height turned out not to be practically feasible in the home interview and was therefore considered unreliable.

The section involving the assessment of physical activity was altered in the general questionnaire on life-style. This part consisted of questions taken from a validated questionnaire, ${ }^{6}$ but did not appear to be feasible in this case-control 
interview setting. Originally the physical activity questionnaire was designed to inquire about current behaviour. In the case-control study it should refer to the previous year and for cases to the period before diagnosis or complaints, which could not be reliably answered by the participants. To our knowledge, no validated questionnaire on physical activity based on a retrospective design was available during the conduct of the study.

The combined use of fermented dairy products (cheese, buttermilk, yogurt) and nitrate-rich vegetables was assessed in the original questionnaire. The questions appeared too difficult to ask and to answer and were skipped from the questionnaire.

Participants in the home interview were asked to collect toenails. It was originally planned to analyse these toenails for selenium status. However, considering the costs and the findings of recently conducted epidemiological studies, which did not support the hypothesized inverse association between selenium and colon cancer, ${ }^{7}$ it was decided not to conduct such analyses.

\section{Validity of dietary data and information bias}

The structure of the dietary history questionnaire was similar to that used by van 't Veer and co-workers in a previous case-control study on breast cancer. ${ }^{8}$ The internal consistency checks and correction procedures are similar to those used in the breast cancer case-control study and to those used in the semi-quantitative food frequency questionnaire of the Netherlands Cohort Study on diet and cancer."

Besides being interviewed with the dietary history questionnaire, 114 controls who participated in the previous case-control study on breast cancer also filled out the food frequency questionnaire used in the Netherlands Cohort Study. ${ }^{10}$ In the cohort study the food frequency questionnaire was validated against a 3-day record repeated three times. ${ }^{9}$ With respect to macro- and micronutrients, the dietary history was related to both the food frequency questionnaire and the dietary record. Coefficients of correlation were similar for both comparisons. ${ }^{10}$

To study whether the food-frequency questionnaire used in the cohort study could be used in a case-control design, this questionnaire was additionally completed by 77 cases and 80 controls participating in the dietary history interview of our casecontrol study. These data will be analysed at a later stage.

To assess significance of differences between interviewers two-way analysis of variance was conducted. The difference in intake of energy and calcium (and therefore dairy product consumption) between cases and controls did not differ markedly between interviewers.

Total energy intake was significantly higher among cases, which is supported by

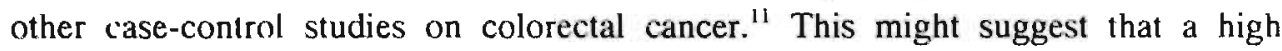


energy intake increases the risk of colon cancer but, more likely, it might point to the fact that cases overestimate their habitual intake. Both explanations, however, require nutrient intakes to be adjusted for total energy intake in data analysis.

One case was excluded from the analysis since the interviewer evaluated the dietary history data as unreliable and total energy intake exceeded $25,000 \mathrm{~kJ}$.

\section{References}

1. Garland CF, Garland FC, Gorham ED. Can colon cancer incidence and death rate be reduced with calcium and vitamin D? A.m J Clin Nutr 1991;54:193S-201S.

2. Schlesselman JJ. Case-control studies. Design, conduct, analysis. Oxford University Press. New York/Oxford, 1992.

3. van 't Veer P. Dietary habits and breast cancer: a case-control study in the Netherlands. Ph.D Thesis, May 1990.

4. Schouten LJ, Jager JJ, van den Brandt PA. Quality of cancer registry data: a comparison of data provided by clinicians with those of registration personnel. Brit J Cancer 1993;68:97477.

5. Nevo tabel. Dutch food composition table 1989-90. The Haque, Netherlands: Voorlichtingsbureau voor de Voeding. Stichting Nevo 1989.

6. Baecke JAH, Burema J, Frijters JER. A short questionnaire for the measurement of habitual physical activity in epidemiologic studies. Am J Clin Nutr 1982;36:936-942.

7. van den Brandt PA, Goldbohm RA, van ' $t$ Veer P, et al. A prospective cohort study on toenail selenium levels and the risk of gastrointestinal cancer. J Natl Cancer Inst 1993;85:224-229.

8. van 't Veer P, Kok FJ, Brants HAM, Ockhuizen Th, Sturmans l'. Hermus RJJ. Dietary fat and the risk of breast cancer. Int J Epidemiol 1990:19:12-18.

9. Goldbohm RA, van den Brandt PA, Brants HAM, et al. Validation of a dietary questionnaire used in a large-scale prospective cohort study on diet and cancer. Eur $\mathrm{J}$ Clin Nutr $1994: 48: 253-265$.

10. van ' 1 Veer P, Kardinaal AFM, Bausch-Goldbohm RA, Kok FJ. Biomarkers for validation. Eur J Clin Nutr 1993;47(suppl 2):S58-S63.

11. Willett WC and Stampfer MJ. Total energy intake: implications for epidemiologicall analyses. Am J Epidemiol 1986;124:17-27. 


\section{Chapter 5}

Fermented dairy products, dietary calcium and colon cancer: a case-control study in the Netherlands

Ellen Kampman, Pieter van 't Veer, Gert Jan Hiddink, Petra van Aken-Schneijder, Frans J.

Kok, Rudolph J.J. Hermus. Int $J$ Cancer: in press (with minor textual modifications) 


\section{Abstract}

To examine whether the consumption of fermented dairy products or the dietary intake of calcium decreases colon cancer risk, a case-control study was conducted in the Netherlands. Dietary patterns were assessed in detail among 232 cases and 259 controls (for cases before diagnosis or symptoms occurred) using a structured dietary history questionnaire.

After adjustment for potential confounding variables, consumption of fermented dairy products, hard cheese and unfermented dairy products was not significantly associated with risk of colon cancer: an odds ratio (OR) of 1.1 (95\% confidence interval $(\mathrm{CI})=0.6-1.8$ ) was found for individuals consuming more than one serving of fermented dairy products per day as compared to those consuming less than $10 \%$ of one serving a day. Adjustment for dietary calcium attenuated the associations. Total dietary calcium was positively but non-significantly associated with colon cancer risk after adjustment for age, gender, urbanization level and total energy intake (OR highest vs. lowest quartile of intake $=1.4 ; 95 \% \mathrm{CI}=0.9-2.4$ ). Additional adjustment for a positive family history of colorectal cancer, cholecystectomy and energy-adjusted intake of total fat, dietary fiber, vitamin $\mathrm{C}$ and alcohol increased the association (OR highest vs. lowest quartile of intake $=1.8$; $95 \% \mathrm{CI}=1.1-3.1$ ). No differences were observed between calcium from fermented and calcium from unfermented dairy sources.

The observed associations for fermented dairy products and dietary calcium differed between men and women: positive significant associations were observed in men, while in women non-significant inverse associations were found.

These results do not support the hypothesis that an increased intake of commercially available, commonly used fermented dairy products or dietary calcium decreases the risk of colon cancer. 


\section{Introduction}

Since colon cancer incidence and mortality are still relatively high in westernized countries and new treatment strategies are not expected to be available in the near future, preventive measures seem to be essential in controlling this disease. Minor changes in dietary patterns might offer substantial possibilities for prevention. ${ }^{1}$ Already in 1908, Eli Metchnikoff propagated an increased consumption of fermented foods, especially milk products such as yogurt, cultured milk and cheese, to suppress colon carcinogenesis. ${ }^{2}$ Recent animal and human experimental studies support the idea that certain strains of lactic acid bacteria might decrease colon cancer risk. ${ }^{3}$ Several potential mechanisms of action have been suggested: decrease in activity of faecal enzymes thought to be involved in colon carcinogenesis by certain strains of Lactobacillus, ${ }^{3.5}$ suppression of tumors through enhancement of the immune response, ${ }^{6,7}$ cellular uptake of mutagenic compounds, ${ }^{8}$ and antioxidative properties of specific strains. ${ }^{9}$

Moreover, fermented dairy products are an important source of calcium in a westernized diet. Calcium is suggested to decrease colon cancer risk through a decreased cell proliferation induced either by cell differentiation ${ }^{10}$ or by binding of toxic bile acids and free fatty acids in the colonic lumen. ${ }^{11}$ Milk products are rich in phosphate, which has been hypothesized to inhibit the antiproliferative effect of calcium, ${ }^{11}$ while in vitro studies have shown that bile acids are precipitated by insoluble calcium phosphate. ${ }^{12}$

It is still unknown whether generally consumed and commercially available fermented dairy products exert an anticarcinogenic or antimutagenic effect. Few epidemiological studies have addressed the association between consumption of fermented dairy products (excluding cheese) and colon cancer risk. ${ }^{13-15}$ Two population-based American case-control studies did observe an inverse association with the consumption of cultured milk (yogurt and buttermilk) ${ }^{14}$ and yogurt ${ }^{15}$ after adjustment for potential confounding factors.

The association with the intake of dairy products in general and/or calcium is studied more often in case-control and cohort studies, but results remain inconsistent. ${ }^{15-24}$ Some studies suggest stronger associations for women than for men. $17,24,25$

In contrast with the countries in which these studies have been conducted, the Netherlands is known for its high per capita consumption of fermented dairy products (e.g. $18.9 \mathrm{~kg}$ per year vs. $2.1 \mathrm{~kg}$ per year in the US) ${ }^{26}$ and the substantial heterogeneity of its consumption patterns. In previous Dutch case-control studies on 
breast cancer $^{27}$ and cancer of the exocrine pancreas ${ }^{28}$ inverse associations with fermented dairy product consumption were observed.

We studied the association between fermented dairy products, the intake of calcium from different dairy and non-dairy dietary sources, and colon cancer risk among men and women in a case-control study using a structured dietary history questionnaire to assess usual fermented dairy product consumption and other dietary variables in greater detail.

\section{Subjects and methods}

A case-control study of colon cancer was conducted in the Netherlands between 1989 and 1993. Dutch-speaking men and women of west European origin, up to the age of 75 at diagnosis, who resided in the central or eastern parts of the Netherlands and did not have a history of cancer, ulcerative colitis or Crohn's disease were eligible for this study.

Cases

Cases were defined as newly diagnosed and histologically confirmed patients with adenocarcinomas of the colon (ICD-O 153). They were recruited as soon as possible after diagnosis by their medical specialists in 14 regional hospitals. The cancer registries of the central and eastern parts of the Netherlands were used as a check of completeness and provided additional clinical and pathological information. For 28 cases, the cancer registry defined the location of the tumor as rectosigmoid while according to the surgeon the tumor was located in the colon. Analyses were conducted both including and excluding these cases.

Of all eligible cases diagnosed in the cooperating hospitals, $47 \%$ were invited to participate. Cases invited did not differ importantly from those not invited in age, gender, urbanization level and site distribution. Cases who were not invited had a worse prognosis according to Dukes' status and more frequently underwent radiotherapy and chemical therapy. Of those invited, $60 \%$ agreed to be interviewed. Except for Dukes' status, the distributions of age, gender, tumor site and therapies of the interviewed cases were comparable to those of all eligible cases. All participants and $23 \%$ of the non-participants completed a short questionnaire which included questions on the most relevant dietary and life-style factors. Cases participating in the interview consumed less fermented dairy products than those non-participants who filled out the questionnaire. The two groups did not differ markedly in their consumption of unfermented dairy products. The interval between diagnosis and interview was about three to six months. 


\section{Controls}

Population controls, of similar age (5-year intervals), gender, region and degree of urbanization as the cases, were recruited randomly by the general practitioners of the participating cases. Of the 520 controls invited, 57\% agreed to participate in the interview. Participation was higher among younger people and those living in urban areas. Dietary and life-style pattems did not differ importantly between those who participated in the interview and those who refused to participate but completed the non-response questionnaire ( $42 \%$ of non-participants).

\section{Questionnaire}

Trained dieticians conducted personal interviews in the participant's home. Each interviewer visited both a case and a control of the same age, gender, region and urbanization level. Interviewing cases and controls was balanced over seasons to account for seasonal fluctuations in food patterns. The interview consisted of a dietary history part and questions considering life-style, medical history and family history of colorectal cancer.

The hierarchically structured part ${ }^{29}$ was divided into five sections according to national habits and starting with the most intensive part, the main meal (appetizers, main dishes), followed by breakfast and lunch, desserts, (non-)alcoholic drinks and snacks. The questionnaire covered the complete dietary pattern. The consumption frequency per month in the preceding year (in cases before diagnosis or symptoms), number of months duiring which the item was used, number of portions per consumption and portion size of 289 food items from 19 food groups were inquired. The questionnaire included all major dairy products consumed in the Netherlands. To be able to estimate portion sizes, frequently used household utensils and cups were weighed.

To minimize errors, the dietary history questionnaire was entered into the computer using a specially designed computer program which included rangechecks and cross-checks. Checks on the internal consistency of the frequency of consumption of various meal components with the total meal pattern were conducted. Frequencies of individual items were corrected automatically in order to agree with the frequency of the total food group.

Average daily intake of dietary calcium and other nutrients was calculated using the Dutch National Food Table. ${ }^{30}$ Intake of nutrients was adjusted for energy intake by regression analysis ${ }^{31}$ for men and women separately.

To exame the stability of food habits, changes in habits as a result of gastrointestinal complaints were inquired.

The non-dietary part of the interview included questions on socio-demographic indicators (e.g. age, education, occupation, urbanization level), medical history (e.g. 
cholecystectomy), supplement use, family history of colon cancer, reproductive factors (number of children and age at first birth) and, among female participants, on menstrual history and use of oral contraceptives. Occupation was used as a measure of socio-economic status (SES); for married women (including divorcees and widows), SES was based on their (former) husband's occupation.

\section{Data analysis}

In this analysis emphasis was on three groups of dairy products: fermented dairy products (buttermilk, yogurt, curds and kefir); hard cheese (i.e. Gouda cheese) and unfermented dairy products (whole-fat milk, skim/low-fat milk, custards, evaporated milk and porridge). The intake of dairy products is expressed in grams per day. Categories or quartiles of dairy product use and dietary calcium intake were based on the distribution among controls. The lowest category or quartile of intake was used as the reference. Different sources of dietary calcium were explored. Since these analyses focussed primarily on calcium from dietary sources, supplemental calcium (alone, with vitamin D, or as multivitamin supplement) was examined as a confounder and coded as a dichotomous variable (use yes or no).

A high phosphorus intake relative to the intake of calcium was evaluated using quartiles of the ratio of calcium to phosphorus with the lowest quartile as the reference.

Odds ratios (OR) as estimators of relative risks and approximate $95 \%$ confidence intervals $(95 \% \mathrm{Cl})$ were calculated by unconditional maximum likelihood estimation using BMDP software.

Variables for which frequency matching was conducted (age, gender and urbanization level) were included in all statistical models. Total energy intake was additionally included to adjust for differential overreporting.

To evaluate the potential confounding effects of energy-adjusted intake of fat, carbohydrates, dietary fiber and vitamin $\mathrm{C}$, smoking habits, calcium supplement use, socio-economic status, cholecystectomy and family history of colorectal cancer, these covariates were added to the logistic regression model one at a time. Decisions on which covariates to include in the final models were based on: 1) literature and previous studies, ${ }^{32}$ 2) biological plausibility, 3) whether the regression coefficient of the primary independent variable changed by $10 \%$ or more after addition of the potentially confounding variable, and 4) whether the covariate entered the model at $p<0.10$. A priori it was decided to adjust for nutrients instead of food groups.

We tested for overall trends by using the median of each quartile as a continuous variable. Since no apparent differences were found in the analyses after exclusion of 
potential rectosigmoid cases (data not shown), results are presented including these cases.

\section{Results}

Table 5.1 shows various characteristics of controls according to high and low intake of fermented dairy products and dietary calcium. Those in the highest quartile of fermented dairy product consumption (mean intake $391 \mathrm{~g}$ per day excluding cheese) did not differ importantly in energy intake and energy-adjusted intake of dietary calcium, dietary fiber and alcohol from those in the lowest quartile (mean intake $4 \mathrm{~g}$ per day).

Energy-adjusted intake of fat was higher among those with the lowest intake, while vitamin $\mathrm{C}$ intake was higher among the most frequent consumers. Women did consume fermented dairy products more frequently than men and those with the highest intake were younger. Body mass index and a family history of colorectal cancer did not differ appreciably between the two categories of intake. Although not significantly different, cholecystectomy prevalence was higher, socio-economic level was higher, calcium phosphate ratio was higher and calcium supplements were used more frequently among those with the highest intake. The highest category of intake included less current smokers.

Dietary calcium intake was not strongly associated with age, gender, encrgyadjusted intake of fat and alcohol, body mass index, cholecystectomy, calcium supplement use or history of colorectal cancer. Total energy intake and energyadjusted intake of dietary fiber and vitamin $\mathrm{C}$ were higher and calcium/phosphorus ratio was higher among those with the highest dietary calcium intake. Those in the highest quartile of intake had a higher socio-economic level and less persons currently smoked.

Table 5.2 illustrates the distribution of colon cancer cases and controls according to dairy product consumption and dietary calcium intake. The median intake of fermented dairy products, hard cheese, unfermented dairy products and total dietary calcium was higher among cases.

In Table 5.3 odds ratios of colon cancer are presented according to dairy product consumption. The consumption of fermented dairy products, hard cheese and unfermented dairy products was not significantly associated with colon cancer risk adjusted for age, gender, urbanization level and total energy intake. For the most frequently used fermented dairy products, yogurt and buttermilk, a non-significant positive and inverse association was observed respectively. For neither whole milk nor skim milk or low-fat milk important associations were observed. 
Table 5.1 Characteristics of controls $(n=259)$ according to highest and lowest quartiles of fermented dairy product consumption and calcium intake.

Fermented dairy products (excl. cheese) $\quad$ Calcium

\begin{tabular}{|c|c|c|c|c|c|c|}
\hline Variables & Q1 & Q4 & & Q1 & Q4 & \\
\hline Age $\pm \mathrm{SD}$ & $63.9 \pm 9.1$ & $60.6 \pm 8.7 *$ & ** & $62.4 \pm 9.9$ & $62.0 \pm 9.2$ & \\
\hline Gender ( $\%$ men) & $66.7 \pm 5.8$ & $32.8 \pm 5.8 *$ & ** & $50.8 \pm 6.2$ & $60.9 \pm 6.1$ & \\
\hline \multicolumn{7}{|l|}{ Dietary factors (mean $\pm \mathrm{SD}$ ) } \\
\hline Fermented dairy (excl. cheese) (g/day) & $4 \pm 7$ & $391 \pm 171$ & ** & $82 \pm 95$ & $222 \pm 241$ & $* *$ \\
\hline Hard cheese ( $g /$ day) & $35 \pm 29$ & $37 \pm 26$ & & $18 \pm 12$ & $63 \pm 38$ & $* *$ \\
\hline Unfermented dairy (g/day) & $284 \pm 223$ & $211 \pm 272$ & * & $122 \pm 108$ & $488 \pm 320$ & ** \\
\hline Dietary calcium (mg/day) $)^{\dagger}$ & $1,150 \pm 355$ & $1,436 \pm 449$ & & $905 \pm 180$ & $1,722 \pm 412$ & $* *$ \\
\hline Total energy (kJ/day) & $9,062 \pm 2,527$ & $9,023 \pm 2,893$ & & $8,047 \pm 2,200$ & $11,125 \pm 2,97$ & $3 * *$ \\
\hline Total fat $(g / \text { day })^{\dagger}$ & $108 \pm 24$ & $92 \pm 22$ & ** & $103 \pm 23$ & $101 \pm 28$ & \\
\hline Dietary fiber ( $\mathrm{g} /$ day $)^{\dagger}$ & $28 \pm 8$ & $30 \pm 7.7$ & & $26 \pm 7$ & $31 \pm 9$ & ** \\
\hline Vitamin $\mathrm{C}(\mathrm{mg} / \text { day })^{\dagger}$ & $104 \pm 54$ & $135 \pm 55$ & ** & $95 \pm 40$ & $132 \pm 60$ & ** \\
\hline Alcohol $(\mathrm{g} / \text { day })^{\dagger}$ & $16 \pm 20$ & $11 \pm 16$ & & $17 \pm 18$ & $12 \pm 18$ & \\
\hline Calcium/phosphorus ratio ${ }^{\dagger}$ & $0.7 \pm 0.1$ & $0.8 \pm 0.1 *$ & ** & $0.6 \pm 0.1$ & $0.8 \pm 0.1$ & $* *$ \\
\hline \multicolumn{7}{|l|}{ Medical and life-style factors } \\
\hline$\overline{\text { Body mass index (mean } \pm S D)}$ & $26.6 \pm 4.0$ & $25.8 \pm 4.0$ & & $26.5 \pm 4.0$ & $26.0 \pm 3.7$ & \\
\hline Cholecystectomy $\left(\% \pm \mathrm{SE}^{\ddagger}\right)$ & $3.0 \pm 2.1$ & $6.3 \pm 3.0$ & & $4.7 \pm 2.6^{1}$ & $6.3 \pm 3.0$ & \\
\hline Family history of colorectal cancer $\left(\% \pm \mathrm{SE}^{*}\right)$ & $11.1 \pm 4.0^{3}$ & $9.8 \pm 3.8^{3}$ & & $11.5 \pm 4.1^{4}$ & $9.8 \pm 3.8^{3}$ & \\
\hline $\mathrm{SES}\left(\%\right.$ blue collar $\pm \mathrm{SE}^{\ddagger}$ ) & $45.5 \pm 6.1$ & $35.5 \pm 6.1$ & & $51.6 \pm 6.2$ & $22.6 \pm 5.3^{1}$ & $* *$ \\
\hline Current smokers $\left(\% \pm \mathrm{SE}^{ \pm}\right)$ & $42.2 \pm 6.2^{2}$ & $28.1 \pm 5.6 *$ & $*$ & $51.6 \pm 6.2^{1}$ & $26.6 \pm 5.5$ & ** \\
\hline $\begin{array}{l}\left.\text { Current smokers (\% } \pm \mathrm{SE}^{*}\right) \\
\text { Calcium supplement users }\left(\% \pm \mathrm{SE}^{\dagger}\right)\end{array}$ & $15.4 \pm 4.5$ & $25.0 \pm 5.4$ & & $23.1 \pm 5.2$ & $17.2 \pm 4.7$ & \\
\hline
\end{tabular}

s buttermilk, yogurt, curds, kefir, other fermented milk drinks, sour cream.

* different from Q1; $\mathrm{p} \leq 0.1$.

** different from Q1; $p \leq 0.05$.

$1,2,3,4 \quad 1,2,3,4$ missing values respectively. adjusted for total energy intake through regression analysis. instead of $S D, S E=\sqrt{(p(1-p) / n)}$ is given for proportions. 
Table 5.2 Distribution of colon cancer cases $(n=232)$ and population controls $(n=259)$ according to average daily consumption $(\mathrm{g}$ ) of dairy products and daily intake of calcium $(\mathrm{mg})$.

\begin{tabular}{lrrrr}
\hline & cases & & controls \\
& median & $($ P25-P75) & median & (P25-P75) \\
\hline Total fermented dairy products (excl cheese) & 107 & $(17-229)$ & 101 & $(22-242)$ \\
$\quad$ Yogurt & 34 & $(33-100)$ & 26 & $(0-91)$ \\
$\quad$ Buttermilk & 0 & $(0-101)$ & 0 & $(0-113)$ \\
& & & & \\
Hard cheese & 37 & $(20-57)$ & 31 & $(19-49)$ \\
Other cheeses & 0 & $(0-4)$ & 0 & $(0-4)$ \\
& & & & \\
Total unfermented dairy products* & 223 & $(100-473)$ & 205 & $(81-368)$ \\
$\quad$ Whole milk & 0 & $(0-0)$ & 0 & $(0-0)$ \\
$\quad$ Skim/low-fat milk & 66 & $(0-258)$ & 43 & $(0-252)$ \\
& & & & $(1010-1480)$ \\
Total dietary calcium & 1298 & $(1021-1593)$ & 1209 & $(333-683)$ \\
$\quad$ From fermented dairy products & 527 & $(336-729)$ & 485 & $(170-530)$ \\
$\quad$ From unfermented dairy products (incl. cheese) & 319 & $(158-576)$ & 328 & $(296-402)$ \\
$\quad$ From non-dairy products & 335 & $(280-386)$ & 345 & \\
\hline
\end{tabular}

* buttermilk, yogurt, curds, sour cream, kefir, other fermented milk drinks.

** whole milk, skim/low fat milk, chocolate milk, other milk drinks, evaporated milk, custards, porridge.

Additional adjustment for a family history of colorectal cancer, cholecystectomy, energy-adjusted intake of fat, dietary fiber, vitamin $\mathrm{C}$ and alcohol increased the odds ratios for total fermented dairy products, yogurt and unfermented dairy products which was especially due to the inclusion of vitamin $\mathrm{C}$, dietary fiber and cholecystectomy in the model.

However, none of the category specific rates trends were statistically significant. Socio-economic status, calcium supplement use and smoking status were not included in the models since they did not further affect the estimates. Adjustment for dietary calcium diminished the odds ratios (ORs highest vs. lowest quartile for fermented and unfermented dairy products were 0.90 and 1.26 respectively).

Table 5.4 presents the odds ratios for energy-adjusted dietary calcium intake and calcium from different dietary sources. In multivariate models total dietary calcium was positively associated with colon cancer risk. The energy-adjusted intakes of vitamin $\mathrm{C}$ and alcohol acontributed mainly to the increased odds ratio. Neither 
adjustment for vegetables instead of vitamin $\mathrm{C}$ and dietary fiber nor adjustment for meat changed the estimates appreciably.

Table 5.3 Odds ratios of colon cancer for categories of dairy product consumption.

\begin{tabular}{|c|c|c|c|c|c|c|}
\hline \multirow{2}{*}{\multicolumn{2}{|c|}{ Products (g/day) }} & \multicolumn{2}{|c|}{ Number of } & \multicolumn{2}{|c|}{ Odds ratios $(95 \% \mathrm{Cl})$} & \multirow{2}{*}{$\begin{array}{l}\chi^{2^{s}} \\
(p)\end{array}$} \\
\hline & & Cases & $\begin{array}{l}\text { Con- } \\
\text { trols }\end{array}$ & $\begin{array}{l}\text { Adjusted for age, } \\
\text { urbanization level, } \\
\text { gender, total } \\
\text { energy }\end{array}$ & Multivariate* & \\
\hline $\begin{array}{l}\text { Fermented dair } \\
\text { products }\end{array}$ & iry $\begin{array}{r}\leq 22 \\
22-101 \\
101-242 \\
>242\end{array}$ & $\begin{array}{l}66 \\
48 \\
62 \\
56\end{array}$ & $\begin{array}{l}66 \\
65 \\
64 \\
64\end{array}$ & $\begin{array}{l}1.00 \\
0.74(0.44-1.24) \\
1.00(0.61-1.66) \\
0.86(0.51-1.44)\end{array}$ & $\begin{array}{l}1.00 \\
0.84(0.49-1.43) \\
1.16(0.69-1.96) \\
1.06(0.61-1.82)\end{array}$ & $\begin{array}{l}0.27 \\
(0.60)\end{array}$ \\
\hline Buttermilk & $\begin{array}{r}\text { non-users } \\
\leq 113 \\
>113\end{array}$ & $\begin{array}{r}124 \\
54 \\
54\end{array}$ & $\begin{array}{r}132 \\
63 \\
64\end{array}$ & $\begin{array}{l}1.00 \\
0.94(0.60-1.47) \\
0.89(0.56-1.39)\end{array}$ & $\begin{array}{l}1.00 \\
0.99(0.62-1.58) \\
0.94(0.59-1.50)\end{array}$ & $\begin{array}{l}0.06 \\
(0.80)\end{array}$ \\
\hline Yogurt & $\begin{array}{r}\text { non-users } \\
\leq 26 \\
26-91 \\
>91\end{array}$ & $\begin{array}{l}76 \\
29 \\
65 \\
62\end{array}$ & $\begin{array}{l}88 \\
42 \\
65 \\
64\end{array}$ & $\begin{array}{l}1.00 \\
0.84(0.47-1.50) \\
1.20(0.74-1.93) \\
1.16(0.71-1.88)\end{array}$ & $\begin{array}{l}1.00 \\
0.86(0.47-1.55) \\
1.49(0.90-2.45) \\
1.49(0.89-2.49)\end{array}$ & $\begin{array}{l}3.11 \\
(0.08)\end{array}$ \\
\hline Hard cheese & $\begin{array}{r}\leq 19 \\
19-31 \\
31-49 \\
>49\end{array}$ & $\begin{array}{l}55 \\
44 \\
58 \\
75\end{array}$ & $\begin{array}{l}65 \\
65 \\
67 \\
62\end{array}$ & $\begin{array}{l}1.00 \\
0.90(0.52-1.52) \\
1.05(0.63-1.76) \\
1.21(0.72-2.03)\end{array}$ & $\begin{array}{l}1.00 \\
0.92(0.53-1.62) \\
1.08(0.63-1.83) \\
1.18(0.69-2.01)\end{array}$ & $\begin{array}{l}0.57 \\
(0.45)\end{array}$ \\
\hline $\begin{array}{l}\text { Unfermented } \\
\text { dairy products }\end{array}$ & $\begin{array}{r}\leq 81 \\
81-205 \\
205-368 \\
>368\end{array}$ & $\begin{array}{l}42 \\
67 \\
46 \\
77\end{array}$ & $\begin{array}{l}65 \\
65 \\
65 \\
64\end{array}$ & $\begin{array}{l}1.00 \\
1.44(0.85-2.46) \\
0.96(0.55-1.69) \\
1.36(0.79-2.36)\end{array}$ & $\begin{array}{l}1.00 \\
1.59(0.92-2.76) \\
1.01(0.57-1.81) \\
1.59(0.89-2.85)\end{array}$ & $\begin{array}{l}1.12 \\
(0.29)\end{array}$ \\
\hline Milk whole & $\begin{array}{r}\text { non-users } \\
\leq 50 \\
>50\end{array}$ & $\begin{array}{r}180 \\
16 \\
36\end{array}$ & $\begin{array}{r}196 \\
32 \\
31\end{array}$ & $\begin{array}{l}1.00 \\
0.46(0.24-0.89) \\
1.00(0.58-1.73)\end{array}$ & $\begin{array}{l}1.00 \\
0.41(0.21-0.82) \\
0.95(0.54-1.68)\end{array}$ & $\begin{array}{l}0.02 \\
(0.88)\end{array}$ \\
\hline $\begin{array}{l}\text { Skim milk/ } \\
\text { low-fat milk }\end{array}$ & $\begin{array}{r}\text { non-users } \\
\leq 185 \\
>185\end{array}$ & $\begin{array}{l}70 \\
90 \\
72\end{array}$ & $\begin{array}{l}85 \\
88 \\
86\end{array}$ & $\begin{array}{l}1.00 \\
1.38(0.88-2.15) \\
1.01(0.64-1.60)\end{array}$ & $\begin{array}{l}1.00 \\
1.44(0.91-2.29) \\
1.15(0.71-1.84)\end{array}$ & $\begin{array}{l}0.03 \\
(0.85)\end{array}$ \\
\hline
\end{tabular}

s $\chi^{2}$ for trend multivariate model, $\mathrm{p}$-value in parentheses.

* Adjusted for age, gender, urbanization level, family history, cholecystectomy, total energy intake, energy-adjusted intake of fat, dietary fiber, vitamin $\mathrm{C}$ and alcohol. 
Table 5.4 Odds ratios of colon cancer for quartiles of calcium intake.

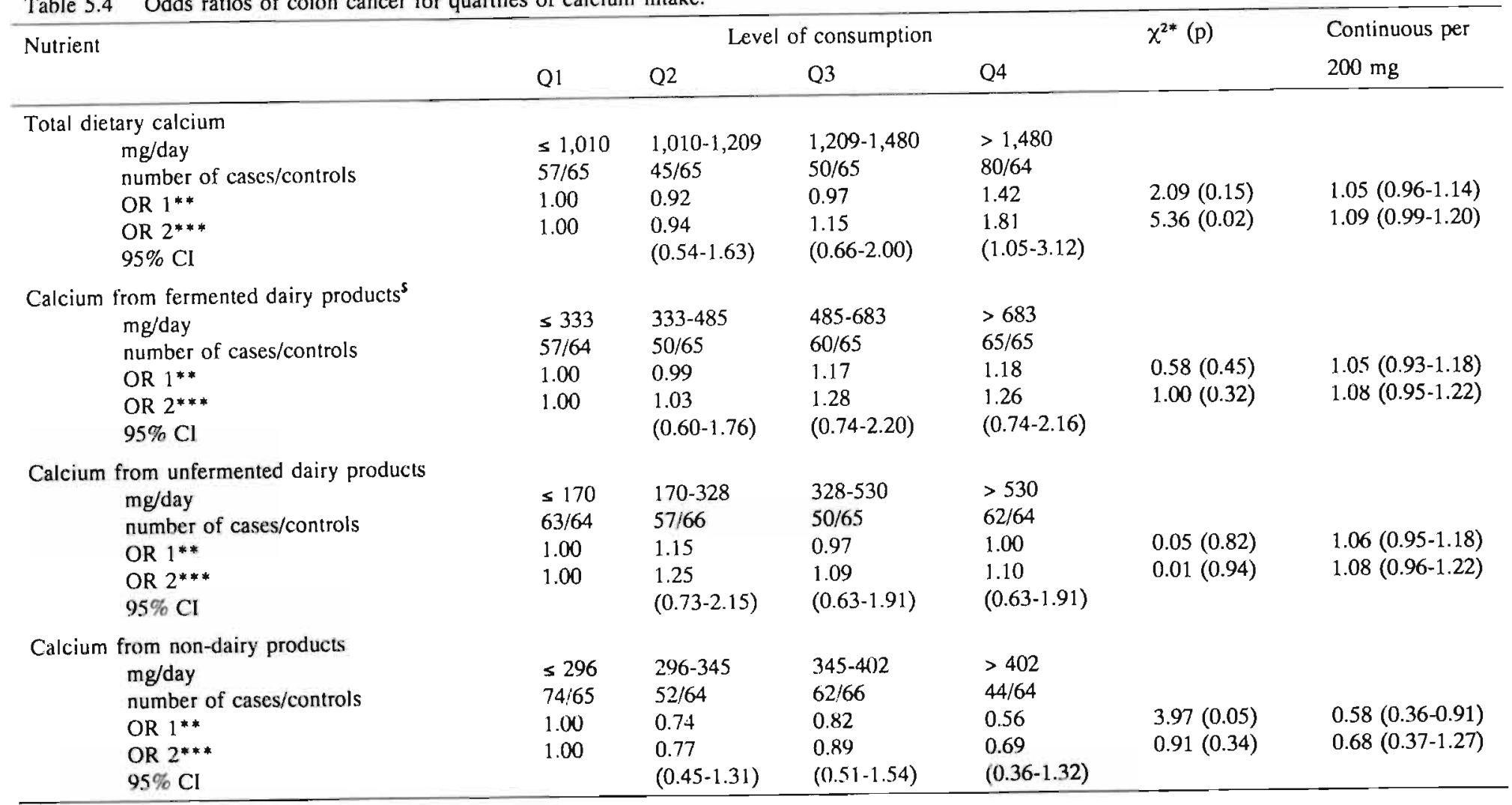

* $\quad \chi^{2}$ for trend.

s fermented milk and cheese.

** OR 1: Adjusted for age, gender, urbanization level, total energy intake.

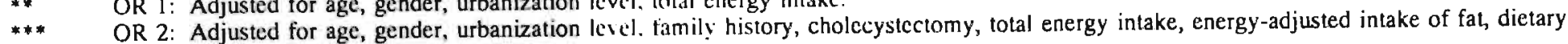
fiber, vitamin $\mathrm{C}$ and alcohol. 
Table 5.5 Odds ratios* of colon cancer for dairy product and dietary calcium intake among men and women.

\begin{tabular}{|c|c|c|c|c|}
\hline \multirow[t]{2}{*}{ Variable } & \multirow[t]{2}{*}{ Contrast ${ }^{*-}$} & \multicolumn{2}{|c|}{ OR for contrast $(95 \% \mathrm{CI})$} & \multirow{2}{*}{$\begin{array}{l}\chi^{2} \\
\text { interaction } \\
\text { (p) }\end{array}$} \\
\hline & & men & women & \\
\hline \multicolumn{5}{|l|}{ Products } \\
\hline Fermented dairy products & $250 \mathrm{~g} /$ day & $1.52(1.00-2.30)$ & $0.77(0.50-1.17)$ & $5.49(0.02)$ \\
\hline $\begin{array}{l}\text { Unfermented dairy } \\
\text { products }\end{array}$ & $250 \mathrm{~g} / \mathrm{day}$ & $1.14(0.91-1.42)$ & $1.12(0.83-1.50)$ & $0.01(0.92)$ \\
\hline \multicolumn{5}{|l|}{ Calcium } \\
\hline Total dietary calcium & $200 \mathrm{mg} / \mathrm{day}$ & $1.17(1.04-1.32)$ & $0.96(0.81-1.12)$ & $3.94(0.05)$ \\
\hline $\begin{array}{l}\text { Calcium from fermented } \\
\text { dairy products }\end{array}$ & $200 \mathrm{mg} / \mathrm{day}$ & $1.20(1.02-1.40)$ & $0.87(0.69-1.09)$ & $5.51(0.02)$ \\
\hline $\begin{array}{l}\text { Calcium from unfermented } \\
\text { dairy products }\end{array}$ & $200 \mathrm{mg} /$ day & $1.09(0.94-1.26)$ & $1.08(0.89-1.30)$ & $0.01(0.93)$ \\
\hline $\begin{array}{l}\text { Calcium from non-dairy } \\
\text { products }\end{array}$ & $200 \mathrm{mg} /$ day & $0.80(0.37-1.72)$ & $0.57(0.26-1.28)$ & $0.49(0.48)$ \\
\hline
\end{tabular}

* adjusted for age, gender, urbanization level, family history, cholecystectomy, total energy intake, energy-adjusted intake of fat, dictary fiber, vitamin $\mathrm{C}$ and alcohol.

** representing about one serving a day.

Calcium from fermented and unfermented dairy sources was positively, although non-significantly associated with risk.

Calcium from non-dairy dietary sources was inversely associated with risk adjusted for age, gender, urbanization level and total energy intake. Additional adjustment for energy-adjusted intake of vitamin $\mathrm{C}$, alcohol, and cholecystectomy attenuated this inverse association.

In the multivariate model, energy-adjusted intake of phosphorus (OR for highest vs. lowest quartile $=1.61,95 \% \mathrm{CI}=0.85-3.06$ ) was positively associated with risk. The calcium/phosphorus ratio was (non-significantly) positively associated with risk when vitamin $C$ was excluded from the multivariate model (OR for highest vs. lowest quartile $=1.49,95 \% \mathrm{CI}=0.87-2.56$ ). Vitamin $\mathrm{C}$ intake was not adjusted for in this model since its inclusion would remove all the variability in calcium.

Table 5.5 shows that the associations with the use of dairy products and dietary calcium intake differed significantly between men and women; positive associations were observed for men, while for women inverse associations were found.

To address recent changes in food patterns, the same analyses were conducted excluding those who reported having had gastro-intestinal discomfort and thus having adapted their dietary patterns in the preceding years (33 cases and 10 
controls). No important differences were observed for fermented milk products (OR for highest vs. lowest intake $=1.28,95 \% \mathrm{CI}=0.72-2.28$ ) or dietary calcium $(\mathrm{OR}=1.85,95 \% \mathrm{CI}=1.04-3.28)$.

\section{Discussion}

The results of this case-control study are not in line with the hypothesis that an increased consumption of commercially available fermented dairy products or an increased intake of dietary calcium would decrease colon cancer risk.

The fact that no association, or even a positive association, was observed may be subject to chance or potential methodological biases in this retrospective study, such as information and selection bias. In this study, both cases and controls were interviewed by the same interviewer in the same season using a structured dietary history questionnaire. General overreporting could occur if some cases remembered consuming more foods in general by concentrating more intensely. Adjustment for total energy intake cannot explain our findings. Since subjects were unaware of the hypothesis tested and dairy products do not have a negative image, it is unlikely that cases would specifically overestimate their consumption of dairy products. This is confirmed in a case-control study of breast cancer by Friedenreich and colleagues $^{33}$ who observed a similar overestimation of calcium in cases and controls.

Changes in food pattems as a result of digestive complaints might be an important reason for recall bias. However, exclusion of those who replied to have changed their dietary habits because of such complaints did not markedly change the results.

The dietary history questionnaire used in this study was a slightly revised version of the validated questionnaire used in our previous case-control study on breast cancer. ${ }^{29}$ Detailed questions on fermented dairy and non-dairy foods were added, which might explain the higher intake of dietary calcium in our control population as compared to the Dutch population in general. Interviewers were trained by one of the authors (P.v.A-S.), who closely supervised their interviewing and coding. No differences between interviewers were found.

Non-response is unlikely to have introduced an important bias in our results. Age, gender and urbanization level of interviewed cases did not significantly differ from those eligible. Cases participating in the interview did have a better prognosis according to Dukes' status. Dukes' status was not related to consumption of fermented dairy products nor to calcium intake. Non-participating cases who filled out a non-response questionnaire appeared to consume more fermented dairy products than participating cases and no differences were observed between 
participating and non-participating controls who completed the questionnaire. However, these findings need to be interpreted with caution since only about $25 \%$ of the non-participating cases and $45 \%$ of the non-participating controls filled out the non-response questionnaire.

In the Netherlands as well as the US, ${ }^{32}$ the consumption of fermented dairy products and calcium is related to a healthier life-style and a higher socio-economic status. If selection of a relatively healthy, health-conscious control group would have occurred, we would have observed no association rather than a positive association for calcium. We recruited the control group via the databases of the general practitioners of the cases interviewed. When we compared this control group with the general population we found a comparable distribution of socioeconomic status. Another control group recruited via the municipal registries included more persons with a higher socio-economic status. Thus, an inverse association might have been erroneously found when municipality controls had been used as in previous studies. ${ }^{27.28}$ In conclusion, information and selection bias are not likely to explain our findings.

The absence of an inverse association cannot easily be explained by insufficient contrast in this population with a relatively high and heterogeneous consumption of fermented and unfermented dairy products.

The significant positive association with dietary calcium might be the results of our adjustment strategy. Excluding vitamin $\mathrm{C}$ from the multivariate model provided an odds ratio of $1.67(95 \% \mathrm{CI}=0.98-2.87)$. Other studies, such as the Iowa Women's Health Study, also observed an increase in the odds ratio for dietary calcium after adjustment for potentially confounding variables. ${ }^{34}$

Significant inverse associations with consumption of fermented dairy products have been found in two American case-control studies. ${ }^{14.15}$ Besides the choice of a control group, the apparent contradiction between our study and or experimental studies might be explained by differences in bacterial strains in local American products and differences in experimentally used strains. In the Netherlands, Lactobacillus bulgaricus and Streptococcus thermophilus, S. tremor and S. lactis are the main species used for the fermentation process of yogurt. These strains are thought to be less resistant to acidic conditions in the stomach while their survival might be essential for a favourable effect in the colon. ${ }^{35}$

Previous epidemiological case-control studies on the role of calcium in colorectal carcinogenesis have yielded conflicting results. Although some case-control and prospective studies suggest a protective role of calcium and dairy products against the risk of colorectal cancer, ${ }^{35,36,37}$ more recent retrospective and prospective studies do not support a protective effect for dietary calcium ${ }^{18,23}$ or only support an inverse relation with colon cancer risk in women. ${ }^{24}$ 
Although the calculations of Garland and colleagues ${ }^{38}$ and Newmark et al. ${ }^{1}$ suggest a considerable reduction of risk with a calcium intake of more than 1,200 or $1,500 \mathrm{mg}$ per day, respectively, dietary intake of calcium in the general population might not be high enough to observe a decrease in risk. In a recent prospective cohort of women in Iowa, no protective effect of dietary calcium was observed $(\mathrm{RR}=0.95)$, while an inverse association was found for calcium from supplements after adjustment for several covariates $(\mathrm{RR}=0.66 ; 95 \% \mathrm{CI}=0.43-1.02 ; \mathrm{p}$ for trend $=0.32){ }^{23}$

Human experimental studies suggest a decrease in cell proliferation with supplemental calcium intake of 1,000 to $2,000 \mathrm{mg}$ per day. ${ }^{10,39-42}$ However, even with these high doses, some recent experimental studies fail to observe an effect of calcium on overall cell proliferation. ${ }^{33,43-45}$ If calcium exerts an effect on cell proliferation it may be particularly important in the early stages of tumor development: i.e. the formation and growth of colorectal adenomas. However, in the Health Professionals Follow-up Study and the Nurses' Health Study, dietary and supplemental calcium intake was not associated with colorectal adenoma risk. ${ }^{32}$

We observed a difference in risk between men and women, which is supported by a recent case-control study in Washington state: ${ }^{24}$ a lower risk of colon cancer was found with higher intakes of calcium among women only. Since women are traditionally more involved in the preparation of the main dish, they might recall their habits more accurately than men. To attenuate recall differences between genders in our study, spouses were asked to be present at the time of the home interview. If recall of diet cannot explain gender differences in the associations found, biological mechanisms might differ between men and women. Besides differences in gut metabolism between men and women, the results of a recent controlled experimental trial suggest gender differences in colonic bacterial population and general colonic milieu. ${ }^{46}$ It is plausible that differences in bile acid metabolism exist between men and women. ${ }^{47}$ As far as fermented dairy products are concerned, certain strains of lactic acid bacteria might colonize the female colon more easily than the male colon.

In summary, this case-control study does not provide support for a protective role of commercially available fermented dairy products or dietary calcium against colon cancer risk. The lack of an inverse association can probably not be explained by information or selection bias. Nevertheless, it would be worthwhile to study this hypothesis prospectively in a population with a similar wide range in intake. It is suggested that experimental studies focusing on differences between male and female bile acid metabolism and large bowel flora might explain the observed differences between men and women. 


\section{References}

1. National Cancer Institute. National Institutes of Health. Diet, Nutrition and Cancer Prevention. A guide to food choices. Washington, DC, US Government Printing Office (NIH Publ. No. 87-2878), 1978.

2. Metchnikoff E. The prolongation of life. Optimistic studies. G.P. Putman and Sons New York 1908.

3. Lidbeck A, Nord CE, Gustafsson J-A, Rafter J. Lactobacilli, anticarcinogenic activities and human intestinal microflora. Eur J Cancer Prev 1992;1:341-353.

4. Goldin BR and Gorbach SL. The effect of milk and lactobacillus feeding on human intestinal bacterial enzyme activity. Am J Clin Nutr 1984;39:756-761.

5. Marteau P, Pochart P, Flourié B, et al. Effects of chronic ingestion of a fermented dairy product containing lactobacillus acidophilus and bifidobacterium bifudum on metabolic activities of the colonic flora in humans. Am J Clin Nutr 1990;52:685-688.

6. De Simone C, Bianchi Salvadori B, Negri R, Ferrazzi M, Baldinelli L, Vesely R. The adjuvant effect of yogurt on production of gamma-interferon by con A-stimulated human peripheral blood lymphocytes. Nutr Rep Int 1986;33:419-433.

7. Perdigon G, Nader de Macias ME, Alvares S, et al. Effect of a mixture of lactobacillus casei and lactobacillus acidophilus administered orally on the immune system in mice. J Food Protect 1986;49:986-989.

8. Zhang $\mathrm{XB}$, Ohta $\mathrm{Y}$, Hosono A. Antimutagenicity and binding of lactic acid bacteria from a Chinese cheese to mutagenic pyrolyzates. J Dairy Sci 1990;73:2702-2710.

9. Kaizu H, Sasaki M, Nakajima H, Suzuki Y. Effect of antioxidative lactic acid bacteria on rats fed a diet deficient in vitamin E. J Dairy Sci 1993:76:2493-2499.

10. Buset $\mathbf{M}$, Lipkin $M$, Winawer S, Swaroop S, Friedman E. Inhibition of human colonic epithelial cell proliferation in vivo and in vitro by calcium. Cancer Res 1986:46:5426-5430.

11. Newmark HL, Wargovich MJ, Bruce WR. Colon cancer and dictary fat, phosphate, and calcium: a hypothesis. J Natl Cancer Inst 1984;72:1323-1325.

12. van der Meer R, Termont DSML, De Vries HT. Differential effects of calcium ions and calcium phosphate on cytotoxicity of bile acids. Am J Physiol 1991;260:G142-G147.

13. Tajima K and Tominaga S. Dietary habits and gastro-intestinal cancers: a comparative casecontrol study of stomach and large intestinal cancers in Nagoya, Japan. Jpn J Cancer Res 1985;76:705-716.

14. Young TB and Wolf DA. Case-control study of proximal and distal colon cancer and diet in Wisconsin. Int J Cancer 1988;42:167-175.

15. Peters RK, Pike MC, Garabrant D, Mack TM. Diet and colon cancer in Los Angeles County, California. Cancer Causes Control 1992;3:457-473.

16. Sorenson AW, Slattery ML, Ford MH. Calcium and colon cancer: a review. Nutr Cancer 1988;11:135-145.

17. Benito E. Obrador A, Stiggelbout A, et al. A population-based case-control study of colorectal cancer in Majorca. I. Dietary factors. Int J Cancer 1990;45;69-76.

18. Negri E, La Vecchia C, D'Avanzo B, Franceschi S. Calcium, dairy products and colorectal cancer. Nutr Cancer 1990;13:255-262.

19. Stemmermann GN, Nomura A, Chyou PH. The influence of dairy and nondairy calcium on subsite large bowel cancer risk. Dis Colon Rectum 1990;33:190-194.

20. Iscovich JM, L'Abbé KA, Castelleto $R$, et al. Colon cancer in Argentina. I: risk from intake of dietary items. Int J Cancer 1992;51:851-857.

21. Steinmetz KA and Potter JD. Food group consumption and colon cancer in the Adelaide case-control study. II. Meat, poultry, seafood, dairy foods and eggs. Int J Cancer 1993;53:720-727.

22. Zaridze D, Filipchenko V, Kustov V, Serdyuk V, Duffy S. Diet and colorectal cancer: results of two case-control studies in Russia. Eur J Cancer 1993;29A:112-115. 
23. Bostick RM, Potter JD, Sellers TA, McKenzie DR, Kushi LH, Folsom AR. Relation of calcium, vitamin $\mathrm{D}$, and dairy food intake to incidence of colon cancer among older women. The Iowa Women's Health Study. Am J Epidemiol 1993;137:1302-1317.

24. Meyer $\mathrm{F}$ and White $\mathrm{E}$. Alcohol and nutrients in relation to colon cancer in middlc-aged adults. Am J Epidemiol 1993;138:225-236.

25. Kune S, Kune GA, Watson IF. Case-control study of dietary etiological factors: The Melbourne colorectal cancer study. Nutr Cancer 1987;9:21-42.

26. Consumption statistics for milk and milk products: 1988 IDF-Bulletin 246, 1990.

27. van 't Veer P, Dekker JM, Lamers JWJ, et al. Consumption of fermented milk products and breast cancer: a case-control study in the Netherlands. Cancer Res 1989;49:4020-4023.

28. Bueno de Mesquita HB, Maisonneuve P, Runia S, Moerman CJ. Intake of foods and nutrients and cancer of the exocrine pancreas: a population-based case-control study in the Netherlands. Int J Cancer 1990;48:540-549.

29. van 't Veer P, Kok FJ, Brants HAM, Ockhuizen Th, Sturmans F, Hermus RJJ. Dietary fat and the risk of breast cancer, Int J Epidemiol 1990;19:12-18.

30. Nevo tabel. Dutch food composition table 1989-90. The Haque, Netherlands: Voorlichtingsbureau voor de Voeding, Stichting Nevo 1989.

31. Willett WC and Stampfer MJ. Total energy intake: implications for epidemiological analyses. Am J Epidemiol 1986;124:17-27.

32. Kampman E, Giovannucci E, van 't Veer $P$, et al. Calcium, vitamin D, dairy foods and the occurrence of colorectal adenomas among men and women in two prospective studies. Am J Epidemiol 1994;139:16-29.

33. Friedenreich CM, Howe G, Miller AB. Recall bias in the association between micronutrient intake and breast cancer. J Clin Epidemiol 1993;46:1009-1017.

34. Bostick RM, Potter JD, Fosdick L, et al. Calcium and colorectal epithelial cell proliferation: a preliminary randomized, double-blinded, placebo-controlled clinical trial. J Natl Cancer Inst 1993;85:132-141.

35. Rambaud JC, Bouhnik Y, Marteau P, Pochart P. Manipulation of the human gut microflora. Proc Nutr Society 1993;52:357-366.

36. Slattery ML, Sorenson AW, Ford MH. Dietary calcium intake as a mitigating factor in colon cancer. Am J Epidemiol 1988;128:504-514.

37. Garland CF, Shekelle RB, Barrett-Connor E, Criqui MH, Rossof AH, Paul O. Dietary calcium and vitamin D and risk of colorectal cancer: a 19-year prospective study in men. Lancet 1985;1:307-309.

38. Garland CF, Garland FC, Gorham ED. Can colon cancer incidence and death rate be reduced with calcium and vitamin D? Am J Clin Nutr 1990;54:193S-201S.

39. Lipkin $M$ and Newmark $H$. Effect of added dietary calcium on colonic epithelial-cell proliferation in subjects of high risk for familial colonic cancer. $N$ Engl $J$ Med 1985;313:1381-1384.

40. Lipkin M, Friendman E, Winawer SJ, Newmark HL. Colonic epithelial cell proliferation in responders and non-responders to supplemental dietary calcium. Cancer Res 1989;49:248254.

41. Wargovich MJ, Isbell G, Shabot M, et al. Calcium supplemention decreases rectal epithelial cell proliferation in subjects with sporadic adenoma. Gastroenterology 1992;103:92-97.

42. O'Sullivan KR, Mathias PM, Beattle S, O'Morain C. Effect of oral calcium supplementation on colonic crypt cell proliferation in patients with adenomatous polyps of the large bowel. Eur J Gastroenterol Hepatol 1993;5:85-89.

43. Gregoire RC, Stern HS, Yeung KS, et al. Effect of calcium supplementation on mucosal cell proliferation in high risk patients for colon cancer. Gut 1989;30:376-382.

44. Stern HS, Gregoire RC, Kashtan H, Stadler J, Bruce RW. Long-term effects of dietary calcium on risk markers for colon cancer in patients with familial polyposis. Surgery $1990 ; 108: 528-533$. 
45. Kleibeuker JH, Welberg JWM, Mulder NH, et al. Epithelial cell proliferation in the sigmoid colon of patients with adenomatous polyps increases during oral calcium supplementation. Brit J Cancer 1993;67:500-503.

46. Lampe JW, Fredstrom SB, Slavin JL, Potter JD. Sex differences in colonic function: a randomized trial. Gut 1993;34:531-536.

47. McMichael AJ and Potter JD. Reproduction, endogenous and exogenous sex hormones, and colon cancer: a review and hypothesis. J Natl Cancer Inst 1980;65:1201-1207. 


\section{Chapter 6}

\section{Reproductive and hormonal factors in male and female colon cancer}

Ellen Kampman, Arianne J. Bijl, Caroline Kok, Pieter van 't Veer. European Journal of Cancer Prevention: in press 


\section{Abstract}

We analysed data from a case-control study in the Netherlands in order to investigate whether reproductive events and hormonal factors are similarly related to colon cancer risk in men and women after adjustment for dietary factors. In total, 232 colon cancer cases (102 women, 130 men) and 259 controls (123 women, 136 men) were interviewed about life-style, medical conditions, and usual dietary patterns, using a structured dietary history technique.

In women, age at first childbirth was positively associated with colon cancer risk (odds ratio $(\mathrm{OR})$ age $\geq 26$ vs. $<26=1.7,95 \%$ confidence interval $(\mathrm{CI})=0.9-3.3$ ). Women with three or more children were at reduced risk compared with women with one or two children $(\mathrm{OR}=0.6,95 \% \mathrm{CI}=0.3-1.1)$. When women had had their first child after the age of 26 years, parity was observed to be important (for 1-2 children vs. $\geq 3$ children $\mathrm{OR}=2.8,95 \% \mathrm{CI}=1.1-7.0$ ). For men, opposite but non-significant associations were found. Adjustment for dietary patterns and other risk factors did not change the estimates markedly.

Of the hormonal factors, late age at menarche decreased risk $(\mathrm{OR}=0.5$, $95 \% \mathrm{CI}=0.3-0.9)$ while late age at natural menopause slightly increased risk.

Our study provides additional support for the role of reproductive status in the aetiology of female colon cancer independently of dietary factors. 


\section{Introduction}

Based on gender differences in colon cancer incidence and tumor site distribution, it has been postulated that hormonal and reproductive factors play a role in the aetiology of this cancer. ${ }^{1}$ These gender differences in risk, however, might also be attributed to reproductive factors influencing behavioural factors, such as diet and physical activity. ${ }^{2}$

McMichael and Potter $^{1}$ proposed the 'hormonal hypothesis', postulating that endogenous oestrogen affects hepatic cholesterol metabolism and increases bile acid production. High concentrations of secondary bile acids in the colonic lumen are thought to enhance colon carcinogenesis. ${ }^{3}$ Pregnancy induces a long-term shift in oestrogen profile and reduces bile acid formation. Progestins and exogenous oestrogen at high doses also decrease bile acid synthesis. ${ }^{1}$ Under this hypothesis, reproductive events could be associated with colon cancer risk among women but not among men.

In order to evaluate this hypothesis, many analytical epidemiological studies have been conducted and reviewed recently. ${ }^{2,45}$ Only four of these studied the association with reproductive factors in both sexes separately."-9 In two of these studies, the number of children a subject had appeared to decrease colorectal cancer risk in men as well as in women, ${ }^{7.8}$ which suggests that life-style factors associated with parity might be important, such as higher physical activity in larger families and altered dietary patterns.

In most studies that investigated reproductive factors, total energy intake and the intake of nutrients relevant to colon cancer were not adjusted for adequately. We studied the relationship between reproductive factors in women and men and hormonal factors in women, taking into account dietary factors and other risk factors of colon cancer.

\section{Subjects and methods}

A case-control study of colon cancer was conducted in the Netherlands between 1989 and 1993. Men and women of West European origin, up to the age of 75 at diagnosis, who resided in the central or eastern part of the Netherlands, spoke Dutch and did not have a history of cancer, ulcerative colitis or Crohn's disease were eligible for this study.

Cases were defined as newly diagnosed and histologically confirmed patients with 
adenocarcinomas of the colon (ICD 153). They were recruited as soon as possible after diagnosis by their medical specialists in 14 regional hospitals. The cancer registries of the central and eastern parts of the Netherlands were used as a check on completeness and provided additional clinical and pathological information. For 28 participants, the cancer registry defined the location of the tumor as rectosigmoid while according to the surgeon the tumor was located in the colon. Analyses were conducted including and excluding these cases.

Of all eligible cases diagnosed in the 14 cooperating hospitals, $47 \%$ were invited by the surgeon to participate. Non-invitation was mainly due to administrative and organizational reasons. Comparison with cancer registry data showed that cases invited did not differ importantly from those not invited with respect to age, sex, urbanization grade and site distribution. However, uninvited cases did have a worse prognosis according to Dukes' status and underwent radiotherapy and chemotherapy more frequently. Of those invited, $60 \%$ agreed to be interviewed. Except for Dukes' status, the distributions of age, gender, tumor site and therapies of the interviewed cases was comparable to the distribution among all eligible cases. A short questionnaire, which included questions on the most relevant dietary and life style factors, was send to the participants as well as the invited non-participants. All participants and $23 \%$ of these non-participants completed this questionnaire and returned it. No important differences were observed between participants and nonparticipants. Because of the low response among non-participants, these data were not incorporated into full analysis. Although the number of participants would have been larger, it would also have been less precise.

The average interval between diagnosis and interview was three months.

\section{Controls}

Frequency matched population controls, matched for age (on 5-year intervals), gender, region and degree of urbanization as the cases, were recruited randomly by the general practitioners of the participating cases. For each case, the general practitioner received a standardized form with three three-letter strings, randomly obtained from the local telephone directory to initiate the search for controls in his or her own database; for each string, the first subject who matched the eligibility criteria was sent a standard letter of invitation, including a reply form to the investigator. Of the 520 controls invited, $57 \%$ agreed-to participate in the interview. Participation was higher among younger people and those living in urban areas. Dietary and life style patterns did not differ significantly between those who participated in the interview and those who refused to participate but completed the non-response questionnaire ( $42 \%$ of non-participants). 


\section{Questionnaire}

A total of seven trained dieticians conducted personal interviews in the participant's home. In order to contain comparable information of cases and controls, each interviewer visited a similar number of cases and controls from the same age, gender, region and urbanization grade. The structured interview included questions on sociodemographic indicators (e.g. age, education, occupation, urbanization grade), medical history (e.g. cholecystectomy), family history of colon cancer, reproductive factors (number of children and age at first birth). Female participants were asked about the type and duration of use of oral contraceptives (OC) and use of oestrogen-replacement therapy, ages at menarche and menopause, and type of menopause (natural or surgical). Occupation was used as a measure of socioeconomic status (SES); socioeconomic status of married women (including divorcees and widows), was based on their husband's (or former/late husband's) occupation.

Data on dietary habits were collected, using a structured dietary history questionnaire $^{10}$ referring to the previous full year (in cases before symptoms occurred). Interviewing cases and controls was balanced over seasons to account for seasonal fluctuations on food patterns. Intake of carbohydrates, fat, fiber and alcohol were adjusted for energy intake by regression analysis ${ }^{11}$ for men and women separately.

\section{Data analysis}

Odds ratios (OR) as estimators of relative risks and approximate $95 \%$ confidence intervals $(95 \% \mathrm{Cl})$ were calculated by unconditional maximum likelihood estimation using BMDP software. ${ }^{12}$ To control simultaneously for the potential confounding effects of age, urbanization grade, energy intake, energy-adjusted intake of fat, carbohydrates, dietary fiber and vitamin $\mathrm{C}$, socioeconomic level, cholecystectomy, and family history of colorectal cancer, multiple logistic regression models were used.

Because of the low numbers of childless cases ( 7 women and 11 men), subjects with one or two children were used as reference. Mean age at birth of first birth (women 26 years; men 28 years) was used to divide into the low and high age at first birth categories.

Exclusion of potential rectosigmoid cases did not change the results appreciably (data not shown).

\section{Results}

Table 6.1 gives the distribution of risk factors among cases and controls, for men 
and women separately. Cholecystectomy and positive family history were more prevalent among cases, but due to the stratification by sex, this was of borderline significance in either men or women $(0.05<\mathrm{p}<0.1)$. No other statistic significant differences were observed.

Table 6.1 Mean and standard deviation (or standard error ${ }^{\dagger}$ ) of some characteristics in 232 people with colon cancer cases and 259 controls subjects.

\begin{tabular}{|c|c|c|c|c|}
\hline & \multicolumn{2}{|c|}{ women } & \multicolumn{2}{|c|}{ men } \\
\hline & $\begin{array}{l}\text { cases } \\
\mathrm{n}=102\end{array}$ & $\begin{array}{l}\text { controls } \\
\mathrm{n}=123\end{array}$ & $\begin{array}{c}\text { cases } \\
\mathrm{n}=130\end{array}$ & $\begin{array}{l}\text { controls } \\
\mathrm{n}=136\end{array}$ \\
\hline Age (years) & $61.3 \pm 10.4$ & $61.2 \pm 10.5$ & $62.7 \pm 10.1$ & $62.3 \pm 9.4$ \\
\hline Urbanization grade (\% urban) & $45.1 \pm 4.9$ & $50.4 \pm 4.5$ & $51.5 \pm 4.3$ & $55.1 \pm 4.4$ \\
\hline \multicolumn{5}{|l|}{ Reproductive factors } \\
\hline Number of children & $2.7 \pm 1.6$ & $2.7 \pm 1.8$ & $2.8 \pm 1.7$ & $2.6 \pm 1.8$ \\
\hline $\begin{array}{l}\text { Age at first birth among } \\
\text { parous (years) }\end{array}$ & $26.3 \pm 4.5$ & $25.9 \pm 3.9$ & $27.8 \pm 4.8$ & $28.7 \pm 4.4$ \\
\hline \multicolumn{5}{|l|}{ Hormone-related factors } \\
\hline Age at menarche (years) & $13.5 \pm 1.8$ & $13.7 \pm 1.5$ & - & - \\
\hline Age at menopause (years) & $48.9 \pm 5.2$ & $48.5 \pm 5.2$ & - & - \\
\hline $\mathrm{OC}$ use $(\%)$ & $47.9 \pm 5.1$ & $47.9 \pm 4.5$ & - & - \\
\hline \multicolumn{5}{|l|}{ Other factors } \\
\hline Cholecystectomy (\%) & $16.2 \pm 3.7$ & $8.1 \pm 2.5^{*}$ & $6.2 \pm 2.1$ & $3.8 \pm 1.7$ \\
\hline $\begin{array}{l}\text { Family history of } \\
\text { colon cancer }(\%)\end{array}$ & $21.1 \pm 4.2$ & $13.6 \pm 3.2$ & $17.5 \pm 3.9$ & $9.5 \pm 2.6^{*}$ \\
\hline Body mass index $\left(\mathrm{kg} / \mathrm{m}^{2}\right)$ & $25.6 \pm 4.9$ & $25.6 \pm 4.3$ & $26.2 \pm 3.7$ & $26.3 \pm 3.3$ \\
\hline Defecation frequency & & & & \\
\hline (\% more than once/day) & $21.0 \pm 4.1$ & $14.6 \pm 3.2$ & $30.7 \pm 4.1$ & $36.0 \pm 4.1$ \\
\hline $\begin{array}{l}\text { Socioeconomic level } \\
(\% \text { blue collar })^{\dagger}\end{array}$ & $50.0 \pm 5.1$ & $42.9 \pm 4.5$ & $44.9 \pm 4.4$ & $38.2 \pm 4.2$ \\
\hline
\end{tabular}

* $p=0.07$.

Instead of SD, $S E=\sqrt{ }(\mathrm{p}(1-\mathrm{p}) / \mathrm{n})$ is given for proportions.

With respect to reproductive- and hormonal-related factors, female controls, compared with cases, tended to have lower age at first birth. Although differences were not significant, defecation frequency was higher among female cases, but lower among male cases than in controls. A higher proportion of female and male cases seemed to have a lower socioeconomic level.

With respect to dietary variables, higher energy intake was found among both female and male cases (Table 6.2). After adjustment for energy intake, cases tended to consume more fat and less carbohydrates, for men these associations did not reach statistical significance. Also, energy-adjusted dietary fiber intake and vitamin 
$\mathrm{C}$ intake were slightly higher in male cases, and significantly higher in female cases. The proportion of alcohol consumers was similar, but among those who consume alcohol mean alcohol intake tended to be higher in cases for both men and women.

Table 6.2 Average daily intake (mean \pm SD or SEM ${ }^{5}$ ) of energy and nutrients $\dagger$ in 232 people with colon cancer and 259 controls subjects.

\begin{tabular}{lcccc}
\hline & \multicolumn{2}{c}{ women } & \multicolumn{2}{c}{ men } \\
& \multicolumn{1}{c}{ cases } & controls & cases & controls \\
& $\mathrm{n}=102$ & $\mathrm{n}=123$ & $\mathrm{n}=130$ & $\mathrm{n}=136$ \\
\hline Energy (kJ) & $8,785 \pm 256$ & $7,841 \pm 2,129^{* *}$ & $11,727 \pm 312$ & $10,737 \pm 2,711^{* *}$ \\
Total fat (g) & $86.0 \pm 14.0$ & $82.5 \pm 14.4^{*}$ & $117.7 \pm 23.0$ & $116.9 \pm 20.8$ \\
Total protein (g) & $74.6 \pm 12.8$ & $74.9 \pm 11.9$ & $93.3 \pm 14.7$ & $91.5 \pm 12.9$ \\
Total carbohydrates $(\mathrm{g})$ & $213.5 \pm 42.0$ & $224.6 \pm 36.7^{* *}$ & $272.1 \pm 56.1$ & $281.1 \pm 49.2$ \\
Dietary fiber $(\mathrm{g})$ & $24.2 \pm 6.6$ & $26.6 \pm 6.7^{* *}$ & $30.3 \pm 8.9$ & $31.1 \pm 9.0$ \\
Vitamin C (mg) & $108.5 \pm 51.5$ & $129.6 \pm 58.6^{* *}$ & $107.6 \pm 53.4$ & $112.3 \pm 48.2$ \\
Alcohol & & & & \\
$\quad \%$ Drinkers & $72.5 \pm 4.4$ & $68.3 \pm 4.2$ & $86.9 \pm 3.0$ & $90.5 \pm 2.5$ \\
Alcohol $(\mathrm{g})^{5}$ & $11.5 \pm 15.3$ & $9.4 \pm 10.4$ & $27.2 \pm 29.0$ & $22.9 \pm 20.6$ \\
\hline
\end{tabular}

* $p<0.1$.

** $p<0.05$.

+ Energy adjusted by regression for men and women separately.

$\$$ SE $V(p(1-p) / n)$.

$\$$ Among alcohol consumers.

Table 6.3 presents ORs for reproductive factors, unadjusted and adjusted for medical and dietary factors. After adjustment ORs became stronger, but this did not change the results dramatically. For women, risk was inversely associated with number of children $(\mathrm{OR}=0.56)$ and positively associated with age at first birth $(\mathrm{OR}=1.69)$. For men, associations with both variables were in the opposite direction.

When both reproductive variables were studied simultaneously, increased risk was essentially limited to women with few children, who had their first child after the age of 26 years $(\mathrm{OR}=2.79)$ (Table 6.4). Additional adjustment for use of oral contraceptives attenuated the OR slightly (OR age at first birth $\geq 26$, number of children $1-2=2.48,95 \% \mathrm{CI}=0.96-6.44)$. For men, a decreased risk was observed in the corresponding exposure category. 
Table 6.3 Reproductive factors among men and women and colon cancer risk.

Women

Odds Ratios (95\% Cl)

Variables

Cases*

Controls Age-adjusted

(n)

(n)

Multivariates

Number of children

$1-2$

$\geq 3$

44

49

$41 \quad 1.00^{\dagger}$

64

$0.68(0.37-1.22)$

$1.00^{\dagger}$

$0.56(0.28-1.11)$

$1.00^{\dagger}$

$38 \quad 55$

$54 \quad 50$

50

$1.56(0.88-2.75)$

$1.00^{\dagger}$

$1.69(0.87-3.27)$

60

58

Men

Odds Ratios (95\% CI)

26

Adjusted for age, urbanization grade, energy intake history of colon cancer and socio-economic level.

+ Reference category.

8 For men $<28$ vs. $\geq 28$

* Missing data on both variables in 2 cases, for 1 case age at first birth was unknown.

* Missing data on both variables in 1 case. 
Hormonal factors (for women) are presented in Table 6.5. Risk was significantly lower for a menarche at age 14 than for an earlier menarche (OR $=0.51,95 \%$ $\mathrm{Cl}=0.28-0.94$ ). Women who had a natural menopause after the age of 50 had a slightly increased risk relative to those with an earlier natural menopause. Artificial menopause and use of oral contraceptives were not associated with colon cancer. Additional adjustment for parity did not change the association with use of oral contraceptives importantly $(\mathrm{OR}=1.10,95 \% \mathrm{CI}=0.49-2.48)$.

Table 6.4 Number of children in different age categories at first birth and colon cancer risk (232 cases, 259 controls).

\begin{tabular}{|c|c|c|c|c|}
\hline & \multicolumn{2}{|c|}{$\begin{array}{l}\text { Women } \\
\text { Age at first birth }(y r)\end{array}$} & \multicolumn{2}{|c|}{$\begin{array}{c}\text { Men } \\
\text { Age at first birth }(y r)\end{array}$} \\
\hline & $<26$ & $\geq 26$ & $<28$ & $\geq 28$ \\
\hline $1-2$ & $1.35(0.50-3.68)$ & $2.79(1.10-7.03)$ & $0.81(0.33-2.01)$ & $0.55(0.27-1.13)$ \\
\hline$\geq 3$ & $1.00^{\dagger}$ & $1.33(0.55-3.20)$ & $1.00^{+}$ & $0.82(0.38-1.79)$ \\
\hline
\end{tabular}

Odds ratios and (in parentheses) 95\% confidence intervals adjusted for age, urbanization grade, energy intake, energy-adjusted intake of fat, carbohydrates, dietary fiber and vitamin $\mathrm{C}$, cholecystectomy, family history of colon cancer and socioeconomic level.

+ Reference category.

Table 6.5 Hormonal factors among women with colon cancer $(n=102)$ and control subjects $(\mathrm{n}=123)$.

\begin{tabular}{llll}
\hline Variables & $\begin{array}{l}\text { Cases* } \\
(\mathrm{n})\end{array}$ & $\begin{array}{l}\text { Controls } \\
(\mathrm{n})\end{array}$ & OR $(95 \% \mathrm{Cl})$
\end{tabular}

\begin{tabular}{lllll} 
& & Age-adjusted & Multivariate $^{s}$ \\
\hline $\begin{array}{l}\text { Age at menarche (years) } \\
\quad \leq 13\end{array}$ & 53 & 52 & $1.00^{\dagger}$ & $1.00^{\dagger}$ \\
$\quad 214$ & 44 & 67 & $0.65(0.38-1.11)$ & $0.51(0.28-0.94)$ \\
& & & & \\
Menopause & & & & $1.00^{\dagger}$ \\
$\quad$ natural, at $<50$ years & 18 & 30 & $1.73(0.81-3.67)$ & $1.38(0.58-3.31)$ \\
$\quad$ natural, at $\geq 50$ years & 37 & 36 & $1.32(0.58-3.03)$ & $0.95(0.36-2.47)$ \\
$\quad$ artificial & 21 & 26 & &
\end{tabular}

Oral contraceptive use

\begin{tabular}{lllll} 
no & 50 & 63 & $1.00^{\dagger}$ & $1.00^{\dagger}$ \\
yes & 46 & 58 & $1.02(0.53-1.93)$ & $0.97(0.46-2.03)$ \\
\hline
\end{tabular}

5 Adjusted for age, urbanization grade, energy intake, energy-adjusted intake of fat, carbohydrate, dietary fiber and vitamin $\mathrm{C}$, cholecystectomy, family history of colon cancer and socioeconomic level.

+ Reference category.

* Strata do not add up to the total because of missing data. 


\section{Discussion}

Our results show that associations between reproductive events and colon cancer risk differ between men and women. The statistically significant association is restricted to women who have fewer than two children and had their first child after the age of 26 . The results appear not to be strongly confounded by other risk factors including dietary factors. The results therefore support the notion that colon cancer in men and women partially differ in aetiology and that sex differences in risk cannot be attributed to life-style factors only.

The results of a case-control study are potentially influenced by selection and information bias. Selection bias in cases may occur when illness affects participation rates. Our study included more cases with Dukes' A and B tumors and fewer cases with a history of radiotherapy or chemotherapy compared with the cancer registry database for the study area. Since a more severe prognosis, or medical treatment influencing appetite, may influence the recall of previous dietary habits, the exclusion of more severe cases can be seen as an advantage, since this might benefit the quality of the dietary data. Controls had a participation rate of $57 \%$; a non-response study showed that non-responders did not differ in age, sex, visits to the general practitioner and type of health insurance as indicators for socio economic status. Furthermore, the proportion of nulliparous women among controls in our study (14.6\%) corresponded with data from the Netherlands Central Bureau of Statistics for 62-year old women in 1992 (15.3\%). With respect to information bias, both cases and controls were asked about their children in the same structured manner by the same interviewer. Subjects and interviewer were not aware of the hypothesis. Thus, selection and information bias are not considered to be important determinants of our results.

Four other studies examined the association between parity and colon or colorectal cancer in both sexes. ${ }^{6-9}$ In a cohort study of 11,888 residents of a retirement community ${ }^{7}$ age-adjusted relative risks (RRs) for men with 1, 2 and 3 or more children compared with childless men were $1.4,0.8$ and 0.4 ; for women, the corresponding RRs showed a similar tendency, i.e. 1.6, 1.1 and 0.5 respectively. The number of colorectal cancer cases was small (58 men, 68 women) and the duration of follow-up was limited to 4.5 years. Relative risks were adjusted for age only and not for other risk factors. The investigators explained their findings by a non-causal relationship resulting from life style variations associated with large families. In the Melbourne study, ${ }^{8}$ a case-control study among 370 male and 305 female colorectal cancer cases and 720 controls frequency-matched for age and sex, having more than one child was found to protect against colorectal cancer in 
women $\quad(\mathrm{OR}=0.62 \quad 95 \% \quad \mathrm{CI}=0.39-0.99) \quad$ and $\quad$ men $\quad(\mathrm{OR}=0.55, \quad 95 \%$ $\mathrm{CI}=0.37-0.83$ ) after adjustment for age at birth of the first child. For colon cancer, for men and women, this $\mathrm{RR}$ was $0.72(95 \% \mathrm{CI}=0.50-1.03)$ and remained stable after adjustment for dietary factors (eg. intake of fiber and fat), family history of colorectal cancer, occupation, and marital status. The investigators suggest the presence of a life style factor that is associated with the number of children as well as colorectal cancer. A Norwegian cohort study among 1.1 million men and 1.1 million women ${ }^{9}$ indicated a decreased risk for caecum and ascending colon cancer in their young sub-population (27 to 57 years old). Age-adjusted RRs for women with $1,2,3$ and 4 children compared to nulliparous women were $0.91,0.64,0.53$ and 0.58 respectively. The investigators suggest that reduction of exposure to bile acids is responsible for this downward trend. No clear inverse association with fatherhood was observed for men, but this did not lead the investigators to exclude the possible effect of life style, whereas the mothers' life style may be more strongly correlated with family size. In an Australian case-control study by Potter and $\mathrm{McMichael}{ }^{6}{ }^{6}$ being unmarried was associated with a non-significant increased risk of colon cancer in both sexes. However, being married without children was associated with a significant increase in risk of colon cancer among women only $(\mathrm{OR}=2.0)$.

Our observations on reproductive factors in women are largely in line with these previous studies. In men however, we observed opposite associations as compared to women, while the Melbourne case-control study showed similar associations. ${ }^{8}$ Of the cohort studies mentioned above, one showed similar results for men and women, ${ }^{7}$ while the other did not. ${ }^{9}$ Thus, the observed sex differences in colon cancer aetiology do not seem to be a simple artefact caused by study design as such, and seem to arise from inconsistent associations among men.

Our findings support the hypothesis that endogenous female sex hormones play a role in the aetiology of colon cancer. The fact that after adjustment for life style variables ORs became somewhat stronger points to the same direction. In a recent review, Potter et al., ${ }^{5}$ note that an inverse association between reproductive events and female colon cancer risk was found in the majority of case-control studies, but not in cohort studies. It has been suggested that higher parity is associated with reduced risk in older women only, ${ }^{5}$ but this hypothesis could not be explored in our study for reasons of statistical power. Cohort studies with a longer follow-up period should especially explore this interesting observation.

Increased physical activity may still provide a possible explanation for the observed lower risk in larger families. Unfortunately, no well-designed and validated questionnaire on physical activity usable in a case-control design was available when this study was conducted. However, it is not very likely that 
physical activity increases strongly with number of children. Nor can physical activity explain the importance of number of children in group older at the time of their first child's birth.

The lower risk in men at older age with fewer than three children as compared to younger men with three or more children might be explained by socio-economic level, which is related to reproductive as well as other factors. However, adjustment for socioeconomic level using different classification systems did not change the results.

Other indicators of a long-lasting or high gastrointestinal exposure to oestrogens are an early age at menarche, late menopause and use of oral contraceptives. Except for age at menarche, no significant associations were observed. An inverse association between age at menarche and colon cancer risk was observed in another European study; ${ }^{13}$ five other studies ${ }^{4,714-16}$ did not find such an association. Franceschi et al. ${ }^{4}$ found a similar (non-significant) protection against colon cancer for premenopausal women, but no difference between natural and artificial menopause, whereas $\mathrm{Wu}$ et al. $^{7}$ found an increased risk associated with surgical menopause $(\mathrm{RR}=1.7,95 \% \mathrm{Cl}=1.0-2.9)$. Late age at menopause was found to be weakly protective in some ${ }^{4.7 .14}$ but not in others. ${ }^{13.15,16}$ Use of oral contraceptives showed no relation with colon cancer risk in our study and other studies. ${ }^{7,14,15,17}$

The observed differences in associations between reproductive events and colon cancer risk for men and women support a role of endogenous female sex hormones in the aetiology of colon cancer independently of dietary factors. The mechanisms of these hormonal influences need to be explored further.

\section{References}

1. McMichael AJ and Potter JD. Reproduction, endogenous and exogenous sex hormones, and colon cancer: a review and hypothesis. J Natl Cancer Inst 1980;65:1201-1207.

2. DeCosse JJ, Ngoi SS, Jacobson JS, Cennerazzo WJ. Gender and colorectal cancer. Eur J Cancer Prev 1993;2:105-115.

3. Hill MJ and Aries VC. Faecal steroid composition and its relationship to cancer of the large bowel. J Pathol 1971;104:129-139.

4. Franceschi S, Bidoli E, Talamini R, Barra S, La Vecchia C. Colorectal cancer in Northeast Italy: reproductive, menstrual and female hormone-related factors. Eur $J$ Cancer 1991;27:604-608.

5. Potter JD, Slattery ML, Bostick RM, Gapstur SM. Colon cancer: a review of the epidemiology. Epidemiol Rev 1993;15:499-545.

6. Potter JD and McMichael AJ. Large bowel cancer in women in relation to reproductive and hormonal factors: a case-control study. J Natl Cancer Inst 1983;71:703-709.

7. Wu AH, Paganini-Hill A, Ross RK, Henderson BE. Alcohol, physical activity and other risk factors for colorectal cancer: a prospective study. Brit J Cancer 1987;55:687-694.

8. Kune GA, Kune S, Watson CF. Children, age at first birth, and colorectal cancer risk. Am J Epidemiol 1989;129:533-542. 
9. Kråvdal $\varnothing$, Glattre $E$, Kvåle $G$, Tretli S. A sub-site-specific analysis of the rclationship between colorectal cancer and parity in complete male and female Norwegian birth cohorts. Int J Cancer 1993;53:56-61.

10. van 't Veer P, Kok FJ, Brants HAM, Ockhuizen Th, Sturmans F, Hermus RJJ. Dietary fat and the risk of breast cancer. Int J Epidemiol 1990;19:12-18.

11. Willett WC and Stampfer MJ. Total energy intake: implications for epidemiological analyses. Am J Epidemiol 1986;124:17-27.

12. BMDP statistical software manual (1988). Volume I and II. Los Angeles: University of California Press, 1988.

13. Negri E, La Vecchia C, Parazzini F, et al. Reproductive and menstrual factors and risk of colorectal cancer. Cancer Res 1989;49:7158-7161.

14. Peters RK, Pike MC, Chang WWL, Mack TM. Reproductive factors and colon cancer. Brit J Cancer 1990;61:741-748.

15. Wu-Williams AH, Lee M, Whittemore AS, et al. Reproductive factors and colorectal cancer risk among Chinese females. Cancer Res 1991;51:2307-2311.

16. Kvåle $G$ and Heuch I. Is the incidence of colorectal cancer related to reproduction? A prospective study of 63,000 women. Int J Cancer 1991;47:390-395.

17. Davis FG, Furner SE, Persky V, Koch M. The influence of parity and exogenous female hormones on the risk of colorectal cancer. Int J Cancer 1989;43:587-590. 



\section{Chapter 7}

Vegetable and animal products as determinants of colon cancer risk in Dutch men and women

Ellen Kampman, Dorette Verhoeven, Lisette Sloots, Pieter van 't Veer. Submitted for publication 


\section{Abstract}

To examine the relationship between colon cancer and vegetable or animal products, we analyzed data from a Dutch case-control study. Dietary patterns were assessed for 232 colon cancer cases and 259 population controls.

In multivariate analyses, the consumption of vegetables was significantly associated with reduced colon cancer risk (Odds Ratio highest vs. lowest quartile of consumption $(\mathrm{OR})=0.4,95 \%$ Confidence Interval $(\mathrm{CI})=0.2-0.7$, p-trend $=$ $0.0004)$. Consumption of fresh red meat was positively associated with risk in women $(\mathrm{OR}=2.4,95 \% \mathrm{CI}=1.0-5.7$, p-trend $=0.04)$, especially for those with a relatively low consumption of vegetables and fruits $(\mathrm{OR}=3.1)$. For men, no association with fresh red meat consumption was found $(O R=0.9)$. No clear associations were found for other products of vegetable or animal origin.

The results of this Dutch case-control study support the preventive potential of a high vegetable-diet in colon cancer risk. This study suggests this may be important for women consuming a diet high in red meat. 


\section{Introduction}

Colon cancer is one of the most prominent types of cancer in the Netherlands, as in many other Westernized countries. In Dutch men, colon cancer incidence ranks third (7\%), behind lung cancer $(24 \%)$ and cancer of the prostate (14\%). For Dutch women, cancer of the colon is the second most common type $(10 \%)$, after breast cancer $(31 \%)$. $^{1}$

Dietary patterns are considered to contribute importantly to the etiology of colon cancer. Research focused primarely on two nutrient hypotheses: dietary fiber is protective, while fat intake increases the risk of colon cancer. Results have been both affirmative and contradictory for nutrients and food groups.

Nowadays, the dietary fiber hypothesis is mostly interpreted as an effect of vegetables and/or fruits, with a variety of nutrients and bioactive substances relevant to the prevention of cancer of the colon as well as many other cancer sites. Although several epidemiological studies addressed the association between colon cancer risk and the consumption of vegetables and fruits as revicwed by Steinmetz. and Potter $^{2}$ and Block et al., ${ }^{3}$ none of these studies were conducted in the Netherlands. Most previous studies in Westernized countries support a protective effect for vegetables: about two-third of the case-control studies observed an inverse association with colon cancer risk for at least one vegetable and/or fruit food group, ${ }^{4 \cdot 18}$ while others reported no association or a positive one. ${ }^{19 \cdot 23}$

Red meat consumption is one of the major sources of saturated fat in a westernized diet. In contrast to the consumption of vegetables, red meat consumption as related to colon cancer risk has been studied in the Netherlands Cohort Study on diet and cancer which showed no important association between red meat consumption and colon cancer risk. ${ }^{24}$ Although supported by other studies, ${ }^{5.16 .17 .21,25}$ these findings contradict results of several studies showing a significant positive association with red meat consumption. $4,11,13,15,18,23,26$ Although differences in dietary methodology and subject recruitment might partially account for such inconsistencies, it may be that meat consumption is not important in itself, but only relative to protective factors provided by vegetables and fruits. ${ }^{24}$ Recently, Steinmetz and Potter ${ }^{27}$ studied the ratio of the consumption of red meat to that of vegetables and fruits. Although not significantly so, this ratio was higher for cases than for controls both in men and women. ${ }^{27}$ A similar approach was used in the Nurses' Health Study for the ratio of red meat to fish and chicken. ${ }^{26}$

Moreover, there are many indications that the association between diet and colon cancer might be different for men and women. Ilowever, previous studies reporting gender-stratified analyses have produced inconsistent findings. ${ }^{69,12,18,27}$ 
In a case-control study, we examined the role of vegetables, fruits, red meat and their ratio as related to colon cancer in Dutch men and women. In addition, we explored associations and potential gender interactions for other food groups of vegetable and animal origin, which have been linked to the risk of colon cancer, such as potatoes, ${ }^{28}$ dairy products, ${ }^{29}$ eggs, ${ }^{27}$ fish and poultry. ${ }^{26}$ Since the numerous components of foods might, through interaction, produce effects which are different from those of the exposure to a single nutrient and interpretation in terms of preventive potentials is easier, we focused especially on the consumption of food groups.

\section{Subjects and methods}

\section{Subjects}

The population based case-control study was conducted in the Netherlands between 1989 and 1993. Cases were defined as newly diagnosed male and female patients with adenocarcinoma of the colon (ICD-O 153). They were recruited from regional hospitals from east and central Netherlands. The cancer registries of these areas were used as a check on completeness and provided additional clinical and pathological information. Cases were Western-European with the Dutch nationality, who were at time of diagnosis up to 75 years old and did not have previous cancer, polyposis coli, ulcerative colitis or Crohn's disease. For 28 cases, the cancer registry defined the location of the tumor as rectosigmoid in contrast with the surgeon who located the tumor in the colon. Analyses were conducted including as well as excluding these cases.

Of all eligible cases diagnosed in the cooperating hospitals, $47 \%$ was invited to participate. Non-invitation was mainly due to technical and administrative reasons. Cases invited did not differ importantly from those not invited in age, gender, urbanization-level and site distribution. Cases who were not invited did have a worse prognosis according to Dukes' status and more frequently underwent radiotherapy and chemotherapy. Of those invited, $60 \%$ agreed to be interviewed. Except for Dukes' status, the distributions of age, gender, tumor site and therapies of the interviewed cases was comparable to the distribution among all eligible cases. In order to explore potential selection bias, participants and non-participants were asked to fill out a short questionnaire on life-style habits and the consumption frequency of dairy products, bread and meat. All participating cases and $23 \%$ of the non-participating cases filled out the questionnaire and returned it. Cases participating in the interview did not differ significantly in the consumption of food groups of major interest from those non-participants who filled out the short ques- 
tionnaire.

The population controls were recruited randomly by general practitioners of participating cases, using the same eligibility criteria as for the cases. They were frequency matched on age, sex and degree of urbanization to the cases. Of the 520 controls invited, $57 \%$ agreed to participate in the interview. Participation was higher among younger people and those living in urban areas. Meat intake, other dietary and life-style patterns did not differ importantly between those who participated in the interview and those who refused to participate but completed the non-response questionnaire ( $42 \%$ of the non-participants).

\section{Data collection}

Cases and controls were interviewed on dietary habits and life-style factors in their own homes by qualified dietitians. For cases, the interval between diagnosis and interview was three to six months. Each dietitian interviewed a similar number of cases and controls in a geographical area. The dietary part of the questionnaire requested information on the frequency of consumption during 1 year prior to interview (for cases before diagnosis or complaints) and consisted of a detailed structured dietary history questionnaire, covering the complete dietary pattern. The frequency of consumption per month, number of months in which the item was consumed, the number of portions per consumption and the size of the portions of 289 food items from 19 food groups were asked for. To be able to estimate portion sizes, frequently used household utensils and cups were weighed.

To minimize errors, the dietary history questionnaire was entered into the computer using a specially designed computer program which included rangechecks and cross-checks. Checks on the internal consistency of the frequency of consumption of various meal components with the total meal pattern were conducted. Frequencies of individual items were corrected automatically in order to agree with the frequencies of the total food group. Average daily intake of nutrients was calculated using the Dutch National Food Table. ${ }^{30}$ Intake of nutrients was adjusted for energy intake by regression analysis for men and women separately. ${ }^{31}$

In addition to diel, subjects were asked about socio-demographic characteristics (e.g. age, urbanization-level, education and occupation), menstrual and reproductive history for women, positive family history of colon cancer, personal medical history, smoking habits and past use of medications. To address stability of food habits, changes in habits as a result of gastro-intestinal complaints were asked for.

\section{Data analysis}

Differences in demographic, predisposing, dietary and life-style factors were compared between cases and controls. The individual food items in the questionnaire were 
categorized into major food groups (e.g. vegetables, fruit, red meat (including fresh red meat) and poultry) which intake was expressed in grams per day. Ratios were calculated for red meat to poultry and fish and for red meat to vegetables and fruits. Calculating ratios, non-users were excluded from the analyses (4 non-users of red meat and 26 non-users of fish or poultry; each participant consumed vegetables or fruits). Including non-users did not change the results importantly (data not shown).

Nutrient intake, food group consumption and the ratios were divided into quartiles according to the distribution in the control group. Odds ratios (OR) for colon cancer as estimates of relative risks, together with their approximate 95\% confidence intervals $(95 \% \mathrm{CI}$ ), were calculated by maximum likelihood estimation using BMDP software, taking the lowest quartile of exposure as the reference. To account simultaneously for the potential confounding effect of age, gender, urbanization-level, energy intake, vitamin C intake (only with nutrient intake), family history of colon cancer, cholecystectomy, socio-economic status, body mass index, smoking habits and alcohol intake, multiple logistic regression models were used. Decisions on which covariates to include in the final models were based on 1) evidence from epidemiological literature, 2) biological plausibility, 3) whether the regression coefficient of the primary independent variable changed $\geq 10 \%$ after addition of the potentially confounding variable and 4) whether the covariate entered the model at the 0.10 level of significance.

Chi-square tests for trend were conducted using the median of each quartile as a continuous variable. Chi-square tests for gender interaction were conducted.

Additionally, odds ratios of those food groups for which an interaction with gender was observed were calculated for men and women separately, with the quartiles based on the distribution of the intake of male and female controls, respectively.

\section{Results}

Mean age was similar among cases and controls (Table 7.1). The case group included more men, less current smokers, less people living in urban areas and a higher proportion of people with lower socio-economic status.

Family history of colon cancer and cholecystectomy was more frequent among cases. The intake of energy, energy-adjusted intake of total fat and total protein was higher among cases, while the energy-adjusted intake of total carbohydrates, dietary fiber, vitamin $C$ and alcohol was less. Total supplement use and use of specific calcium and vitamin D supplements tended to be lower in cases. Cases and controls did not differ in body mass index. 
Table 7.1 Mean and standard deviation of some characteristics in 232 colon cancer cases and 259 controls.

\begin{tabular}{|c|c|c|}
\hline Characteristics & $\begin{array}{l}\text { Cases }(n=232) \\
\text { mean } \pm S D\end{array}$ & $\begin{array}{l}\text { Controls }(n=259) \\
\text { mean } \pm \text { SD }\end{array}$ \\
\hline \multicolumn{3}{|l|}{ Demographic factors } \\
\hline Age (years) & $62 \pm 10$ & $62 \pm 10$ \\
\hline Sex $(\% \text { male })^{\%}$ & $56 \pm 3$ & $53 \pm 3$ \\
\hline Urbanization-level (\% urban) ${ }^{*}$ & $48 \pm 3$ & $53 \pm 5$ \\
\hline Socio economic status (\% blue collar) & $46 \pm 9$ & $40 \pm 3$ \\
\hline \multicolumn{3}{|l|}{ Predisposing factors } \\
\hline \multicolumn{3}{|l|}{ Family history of colorectal } \\
\hline Cholecystectomy $(\%)^{*}$ & $10 \pm 7$ & $5 \pm 6$ \\
\hline \multicolumn{3}{|l|}{ Dietary factors' } \\
\hline Total energy intake $(\mathrm{kJ})$ & $10,433 \pm 3,234$ & $9,362 \pm 2,844^{\ddagger}$ \\
\hline Total fat $(\mathrm{g})$ & $104 \pm 25$ & $101 \pm 25$ \\
\hline Total carbohydrates $(\mathrm{g})$ & $246 \pm 58$ & $254 \pm 52$ \\
\hline Total protein $(\mathrm{g})$ & $85 \pm 17$ & $84 \pm 15$ \\
\hline Dietary fiber $(\mathrm{g})$ & $28 \pm 9$ & $29 \pm 8$ \\
\hline Vitamin $\mathrm{C}(\mathrm{g})$ & $105 \pm 53$ & $118 \pm 54^{\ddagger}$ \\
\hline \multicolumn{3}{|l|}{ Life-style factors } \\
\hline Body mass index $\left(\mathrm{kg} / \mathrm{m}^{2}\right)$ & $26 \pm 4$ & $26 \pm 4$ \\
\hline Current smokers $(\%)^{\prime}$ & $29 \pm 3$ & $33 \pm 3$ \\
\hline Alcohol $(\mathrm{g})$ & $11 \pm 25$ & $14 \pm 18$ \\
\hline \multicolumn{3}{|l|}{ Supplement use } \\
\hline Total $(\%)^{*}$ & $34 \pm 3$ & $37 \pm 3$ \\
\hline Calcium and or vitamin $D(\%)^{*}$ & $11 \pm 2$ & $19 \pm 2$ \\
\hline
\end{tabular}

${ }^{H} \mathrm{SE}=\sqrt{ }(\mathrm{p}(1-\mathrm{p}) / \mathrm{n})$.

"adjusted for total energy intake by regression analysis. separately for men and women.

${ }^{\ddagger} p<0.05$.

Table 7.2a presents odds ratios of colon cancer for quartiles of intakes of several food groups. Considering food groups of vegetable origin, a significant inverse association with vegetable consumption was found after adjustment for total energy and for variables for which frequency matching occurred. For other food groups of vegetable origin no significant associations were found: OR ranged from 0.67 for potatoes to 1.16 for cereal products (Table 7.2a). For the consumption of legumes no important associations were found as well ( $\mathrm{OR}=1.08 ; 95 \% \mathrm{CI}=0.67-1.76$ ). However, in this population legumes were consumed too infrequent to draw firm conclusions. 


\begin{tabular}{|c|c|c|c|c|c|c|}
\hline Variable & Q1 & Q2 & Q3 & Q4 & $\chi^{2}$ trend ( $p$-value) & $\begin{array}{l}\chi^{2} \text { gender int } \\
\text { (p-value) }\end{array}$ \\
\hline \multicolumn{7}{|l|}{ VEGETABLE PRODUCTS } \\
\hline $\begin{array}{r}\text { Vegetables (g/day) } \\
\text { cases/controls } \\
\text { OR( } 95 \% \mathrm{CI})^{4} \\
\text { OR }(95 \% \mathrm{Cl})^{4}\end{array}$ & $\begin{array}{l}<142 \\
81 / 65 \\
1.00 \\
1.00\end{array}$ & $\begin{array}{l}142-191 \\
68 / 65 \\
0.82(0.50-1.32) \\
0.73(0.45-1.21)\end{array}$ & $\begin{array}{l}192-247 \\
48 / 65 \\
0.57(0.34-0.95) \\
0.53(0.32-0.89)\end{array}$ & $\begin{array}{l}>247 \\
35 / 64 \\
0.40(0.23-0.69) \\
0.40(0.23-0.69)\end{array}$ & $12.58(0.0004)$ & $1.52(0.22)$ \\
\hline $\begin{array}{l}\text { Fruits (g/day) } \\
\begin{array}{r}\text { cases/controls } \\
\text { OR }(95 \% \mathrm{Cl})^{8} \\
\text { OR }(95 \% \mathrm{CI})^{4}\end{array}\end{array}$ & $\begin{array}{l}<125 \\
62 / 65 \\
1.00 \\
1.00\end{array}$ & $\begin{array}{l}125-198 \\
63 / 65 \\
0.95(0.57-1.58) \\
0.97(0.58-1.63)\end{array}$ & $\begin{array}{l}199-288 \\
51 / 65 \\
0.78(0.46-1.32) \\
0.79(0.46-1.35)\end{array}$ & $\begin{array}{l}>288 \\
56 / 64 \\
0.76(0.45-1.29) \\
0.82(0.84-1.41)\end{array}$ & $0.80(0.37)$ & $4.12(0.04)$ \\
\hline $\begin{array}{l}\text { Potatoes ( } \mathrm{g} / \text { day) } \\
\text { cases/controls } \\
\text { OR(95\% CI })^{8} \\
\text { OR }(95 \% \mathrm{CI})^{4}\end{array}$ & $\begin{array}{l}<79 \\
55 / 67 \\
1.00 \\
1.00\end{array}$ & $\begin{array}{l}79.115 \\
62 / 64 \\
1.23(0.74-2.07) \\
1.23(0.73-2.08)\end{array}$ & $\begin{array}{l}116-171 \\
69 / 65 \\
1.16(0.69-1.95) \\
1.24(0.73-2.11)\end{array}$ & $\begin{array}{l}>171 \\
46,63 \\
0.62(0.34-1.12) \\
0.67(0.37-1.22)\end{array}$ & $1.77(0.18)$ & $0.13(0.72)$ \\
\hline $\begin{array}{c}\text { Cereal products }(\mathrm{g} / \text { day }) \\
\text { cases/controls } \\
\text { OR }(95 \% \mathrm{CI})^{8} \\
\text { OR }(95 \% \mathrm{Cl})^{5}\end{array}$ & $\begin{array}{l}<121 \\
56 / 66 \\
1.00 \\
1.00\end{array}$ & $\begin{array}{l}121-159 \\
55 / 64 \\
0.96(0.57-1.62) \\
1.08(0.63-1.85)\end{array}$ & $\begin{array}{l}160-200 \\
45 / 68 \\
0.60(0.35-1.05) \\
0.69(0.39-1.21)\end{array}$ & $\begin{array}{l}>200 \\
76 / 61 \\
0.99(0.55-1.77) \\
1.16(0.63-2.14)\end{array}$ & $0.08(0.77)$ & $0.62(0.43)$ \\
\hline \multicolumn{7}{|l|}{ ANIMAL PRODUCTS } \\
\hline $\begin{array}{r}\text { Red meat (g/day) } \\
\text { cases/controls } \\
\text { OR }(95 \% \mathrm{CI})^{3} \\
\text { OR }(95 \% \mathrm{Cl})^{3}\end{array}$ & $\begin{array}{l}<52 \\
55 / 67 \\
1.00 \\
1.00\end{array}$ & $\begin{array}{l}52-72 \\
46 / 64 \\
0.84(0.49-1.43) \\
0.80(0.47-1.38)\end{array}$ & $\begin{array}{l}73-94 \\
59 / 67 \\
0.97(0.58-1.63) \\
0.91(0.54-1.55)\end{array}$ & $\begin{array}{l}>94 \\
72 / 61 \\
1.18(0.70-2.00) \\
1.11(0.65-1.90)\end{array}$ & $0.30(0.58)$ & $5.45(0.02)$ \\
\hline $\begin{array}{l}\text { Poultry (g/day) } \\
\text { cases/controls } \\
\text { OR }(95 \% \mathrm{CI})^{5} \\
\text { OR }(95 \% \mathrm{Cl})^{*}\end{array}$ & $\begin{array}{l}<5 \\
67 / 77 \\
1.00 \\
1.00\end{array}$ & $\begin{array}{l}5-10 \\
53 / 53 \\
1.08(0.65-1.82) \\
1.00(0.59-1.70)\end{array}$ & $\begin{array}{l}11-21 \\
66 / 71 \\
1.08(0.67-1.74) \\
1.04(0.64-1.70)\end{array}$ & $\begin{array}{l}>21 \\
46 / 58 \\
0.86(0.51-1.45) \\
0.79(0.46-1.35)\end{array}$ & $0.71(0.40)$ & $0.70(0.40)$ \\
\hline
\end{tabular}


Fish (g/day)

cáses/controls

$\mathrm{OR}(95 \% \mathrm{Cl})^{8}$

$\mathrm{OR}(95 \% \mathrm{Cl})$

Dairy products (g/day)

cases/controls

$\mathrm{OR}(95 \% \mathrm{CI})^{5}$

$\mathrm{OR}(95 \% \mathrm{Cl})^{5}$

Eggs (g/day)

cases/controls

$\mathrm{OR}(95 \% \mathrm{Cl})$

$\mathrm{OR}(95 \% \mathrm{Cl})$

$0.72(0.42-1.22)$

$0.73(0.42-1.24)$

13-24

$>24$

1.00

$0.85(0.5 \mid-1.43)$

$0.85(0.50-1.44)$

$1.15(0.70-1.89)$

$1.13(0.68-1.87)$

$0.84(0.36)$

$0.36(0.55)$

$\begin{array}{ll}<270 & 270-404 \\ 55 / 65 & 51 / 66 \\ 1.00 & 0.84(0.49-1.42) \\ 1.00 & 0.88(0.52-1.51)\end{array}$

\section{5-588}

$44 / 64$

$0.71(0.41-1.21)$

$0.77(0.44-1.34)$

$>588$

$82 / 64$

$1.13(0.67-1.89)$

$1.27(0.75-2.17)$

$1.45(0.23)$

$2.00(0.16)$

1.3-19

8-12

$46 / 66$

$0.86(0.50-1.48)$

$69 / 69$

$1.19(0.71-2.00)$

$0.86(0.50-1.49)$

$1.22(0.72-2.06)$

$>19$

$68 / 59$

$1.22(0.71-2.08)$

$1.17(0.68-2.01)$

$0.79(0.38)$

$0.31(0.58)$

1.00

$1.33-2.52$

$61 / 61$

$1.14(0.67-1.95)$

$2.52-4.73$

$57 / 60$

$1.05(0.61-1.81)$

$>4.73$

$51 / 62$

$1.07(0.62-1.86)$

$1.05(0.60-1.84)$

\section{RED MEAT/VEGETABLES + FRUTTS}

$$
\text { ratio }
$$

\begin{tabular}{|c|c|c|c|c|c|c|}
\hline cases/controls* & $<0.11$ & $0.11-0.18$ & $0.18-0.27$ & $>0.27$ & & \\
\hline OR $(95 \% \mathrm{CI})^{4}$ & $41 / 64$ & $53 i 63$ & $60 / 65$ & $76 / 65$ & & \\
\hline OR(95\% CI $)^{\pi}$ & 1.00 & $1.33(0.77-2.31)$ & $1.47(0.85-2.54)$ & $1.82(1.06-3.13)$ & & $16.23(0.0001)$ \\
\hline & 1.00 & $1.26(0.72-2.22)$ & $1.45(0.83-2.52)$ & $1.76(1.01-3.07)$ & $4.00(0.05)$ & \\
\hline
\end{tabular}

$\S$ adjusted for age, gender, urbanization-level and total energy intake.

7 adjusted for age, gender, urbanization-level, total energy intake, alcohol intake, cholecystectomy and family history of colorectal cancer.

* non-users of food groups included in the denominator and/or nominator were excluded from these analyses. 
Table 7.2b. Total energy intake and the intake of energy-adjusted nutrients as related the risk of colon cancer (both genders combined).

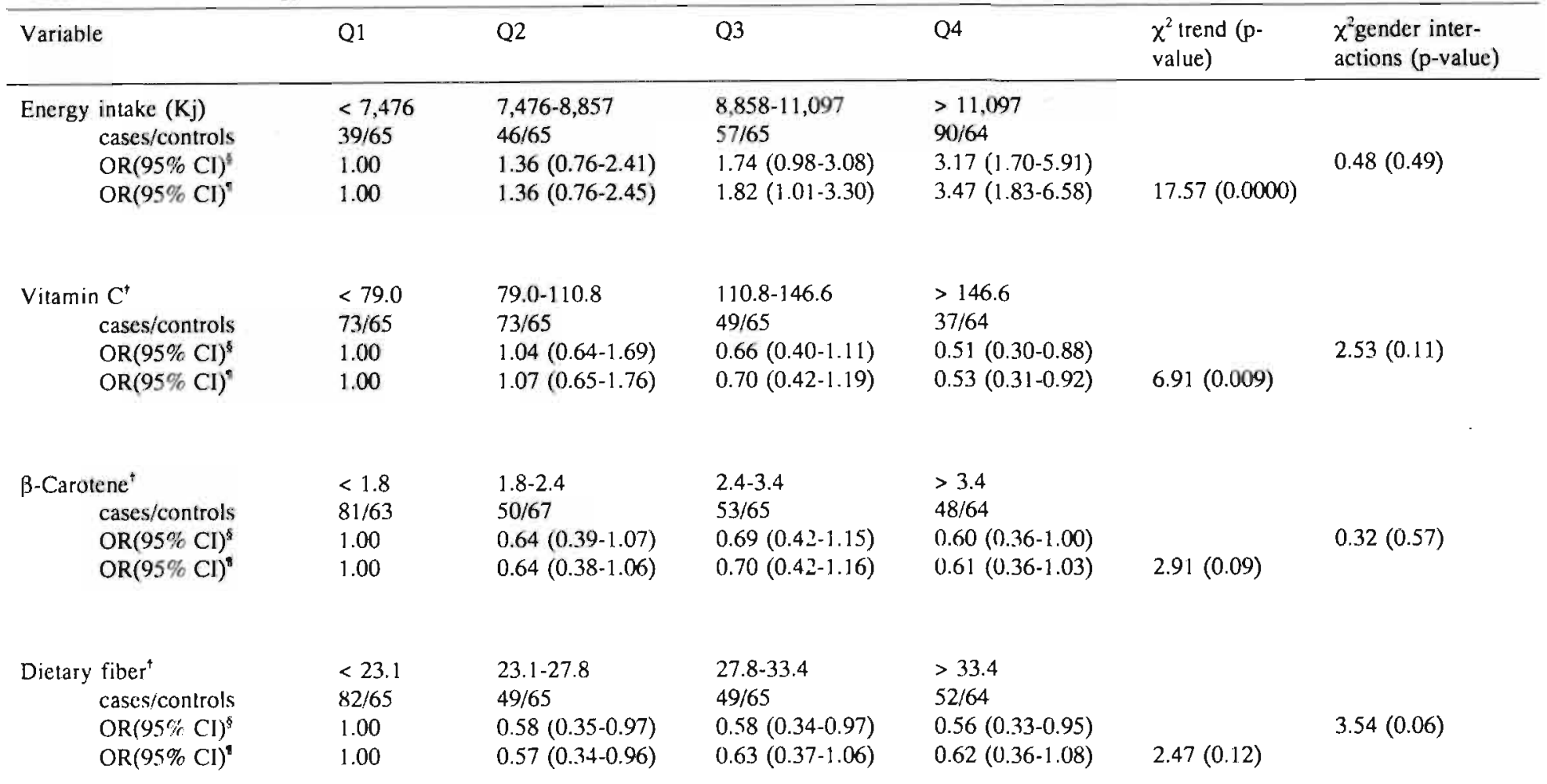




\begin{tabular}{|c|c|c|c|c|c|c|}
\hline Animal protein ${ }^{\dagger}$ & $<48.2$ & $48.2-56.5$ & $56.5-65.4$ & $>65.4$ & & \multirow{4}{*}{$0.09(0.77)$} \\
\hline cases/controls & $54 / 65$ & $45 / 65$ & $66 / 65$ & $67 / 64$ & & \\
\hline $\mathrm{OR}(95 \% \mathrm{CI})^{\delta}$ & 1.00 & $0.87(0.50-1.50)$ & $1.40(0.82-2.40)$ & $1.25(0.72-2.17)$ & \multirow[b]{2}{*}{$1.88(0.17)$} & \\
\hline OR $(95 \% \mathrm{CI})^{\prime}$ & 1.00 & $0.85(0.48-1.49)$ & $1.39(0.80-2.41)$ & $1.32(0.75-2.33)$ & & \\
\hline Saturated fat ${ }^{\dagger}$ & $<33.4$ & $33.4-40.7$ & $40.7-49.5$ & $>49.5$ & \multirow[b]{4}{*}{$0.08(0.78)$} & \multirow{4}{*}{$0.44(0.51)$} \\
\hline cases/controls & $42 / 64$ & $64 / 66$ & $64 / 65$ & $62 / 64$ & & \\
\hline $\mathrm{OR}(95 \% \mathrm{CI})^{5}$ & 1.00 & $1.71(0.99-2.95)$ & $1.80(0.96-3.38)$ & $1.63(0.82-3.23)$ & & \\
\hline OR $(95 \% \mathrm{Cl})$ & 1.00 & $1.53(0.87-2.69)$ & $1.55(0.80-3.01)$ & $1.37(0.66-2.85)$ & & \\
\hline Cholesterol $^{*}$ & $<226.2$ & $226.2-286.0$ & $286.0-347.2$ & $>347.2$ & & \multirow{4}{*}{$0.53(0.47)$} \\
\hline cases/controls & $45 / 65$ & $59 / 65$ & $60 / 65$ & $68 / 64$ & & \\
\hline OR $(95 \% \mathrm{CI})^{\S}$ & 1.00 & $1.58(0.92-2.73)$ & $1.71(0.97-3.03)$ & $1.73(0.95-3.14)$ & & \\
\hline OR $(95 \% \mathrm{CI})$ & 1.00 & $1.43(0.82-2.50)$ & $1.54(0.86-2.78)$ & $1.48(0.80-2.76)$ & $1.21(0.27)$ & \\
\hline
\end{tabular}

1 adjusted for age, gender, urbanization-level and total energy intake.

adjusted for age, gender, urbanization-level, total energy intake, alcohol intake, vitamin $C$ intake (not for $\beta$-carotene and dietary fiber), cholecystectomy, family history of colorectal cancer.

- mg per day, adjusted for total energy intake by regression, separate for men and women. 
Table 7.3 Gender specific associations of fruits, red meat, the ratio of meat to vegetables and fruit with the risk of colon cancer.

\begin{tabular}{llllll}
\hline Variable & Q1 & Q2 & Q3 & Q4 & $\begin{array}{l}\chi^{2} \text { trend } \\
\text { (p-valuc) }\end{array}$ \\
\hline
\end{tabular}

FRUITS

$\begin{array}{rcllll}\text { Men g/day } & <100 & 100-162 & 162-269 & >269 & \\ \text { cases/controls } & 36 / 34 & 25 / 34 & 30 / 34 & 39 / 34 & \\ \text { OR(95\%CI) } & 1.00 & 0.73(0.36-1.49) & 0.80(0.40-1.61) & 0.94(0.48-1.86) & \\ \text { OR(95\%CI) } & 1.00 & 0.77(0.37-1.61) & 0.84(0.41-1.72) & 1.00(0.49-2.03) & 0.02(0.88) \\ \text { Women g/day } & <143 & 143-241 & 241-327 & >327 & \\ \text { cases/controls } & 31 / 31 & 30 / 31 & 24 / 31 & 17 / 30 & \\ \text { OR(95\%CI) } & 1.00 & 0.86(0.41-1.80) & 0.77(0.36-1.69) & 0.48(0.21-1.09) & \\ \text { OR(95\%Cl) } & 1.00 & 0.89(0.42-1.89) & 0.82(0.38-1.79) & 0.54(0.23-1.23) & 2.27(0.13)\end{array}$

RED MFAT

$\begin{array}{rcllll}\text { Men g/day } & <60 & 60-83 & 83-102 & >102 & \\ \text { cases/controls } & 33 / 34 & 35 / 36 & 24 / 3.3 & 38 / 33 & \\ \text { OR(95\% CI) } & 1.00 & 0.82(0.41-1.05) & 0.02(0.30-1.30) & 0.96(0.47-1.92) & \\ \text { OR(95\% CI) } & 1.00 & 0.80(0.39-1.61) & 0.57(0.27-1.20) & 0.89(0.43-1.81) & 0.25(0.62) \\ \text { Women g/day } & <38 & 38-59 & 59-8.3 & >83 & \\ \text { cases/controls } & 12 / 31 & 25 / 33 & 36 / 31 & 29 / 28 & \\ \text { OR(95\% CI) } & 1.00 & 2.05(0.86-4.88) & 2.82(1.21-6.56) & 2.40(1.01-5.73) & \\ {\text { OR }(95 \% \mathrm{CI})^{8}}^{*} & 1.00 & 1.82(0.75-4.46) & 2.71(1.15-6.38) & 2.35(0.97-5.66) & 4.09(0.04)\end{array}$

RED MEAT/VEGETABLES + FRUTTS

\begin{tabular}{rcllll} 
Men ratio & $<0.14$ & $0.14-0.22$ & $0.22-0.33$ & $>0.33$ & \\
cases/controls & $32 / 34$ & $33 / 32$ & $24 / 35$ & $40 / 34$ & \\
OR $(95 \% \mathrm{Cl})^{5}$ & 1.00 & $1.09(0.54-2.20)$ & $0.79(0.38-1.61)$ & $1.28(0.64-2.56)$ & \\
OR(95\%Cl) & 1.00 & $1.04(0.51-2.13)$ & $0.79(0.38-1.64)$ & $1.18(0.57-2.43)$ & $0.16(0.69)$ \\
Women ratio & $<0.09$ & $0.09-0.13$ & $0.13-0.20$ & $>0.20$ & \\
cases $/$ controls & $16 / 33$ & $11 / 26$ & $26 / 32$ & $48 / 31$ & \\
OR $(95 \% \mathrm{CI})^{\$}$ & 1.00 & $0.92(0.36-2.36)$ & $1.65(0.73-3.71)$ & $3.04(1.41-6.56)$ & \\
OR(95\%Cl) & 1.00 & $0.81(0.30-2.17)$ & $1.53(0.67-3.51)$ & $3.05(1.39-6.71)$ & $11.64(0.0006)$ \\
\hline
\end{tabular}

$\S \quad$ adjusted for age, urbanization-level and total energy intake.

i adjusted for age, urbanization-level, total energy intake, alcohol intake, family history of colon cancer and cholecystectomy.

Additional adjustment for other covariates (cholecystectomy, family history and alcohol intake) did not change the odds ratios appreciably. Social economic status, any supplement use, body mass index, smoking habits, and total fat intake did not enter the multivariate model at the 0.10 level of significance, did not appreciably alter the estimates and were therefore not included in the models.

For intake of animal products, non-significant positive associations were found for red meat, dairy products and eggs. A non-significant inverse association was 
observed for poultry consumption. The ratio of red meat to poultry and fish consumption was not importantly associated with risk. The ratio of red meat to vegetables and fruits, however, was significantly positively related to risk. No gender interactions were observed, except for the consumption of fruits, red meat and the ratio of red meat to vegetables and fruits.

Table $7.2 \mathrm{~b}$ presents odds ratios for colon cancer by quartiles of total energy intake and by quartiles of energy-adjusted nutrients from vegetable and animal sources. Energy intake was positively associated with colon cancer. For nutrients related to vegetable intake (dietary fiber, $\beta$-carotene, vitamin $C$ ) inverse associations with risk were found. As a consequence, inclusion of vitamin $C$ in the multivariate model attenuated the odds ratios for dietary fiber and $\beta$-carotene (data not shown). Nutrients related to meat intake (saturated fat, animal protein, cholesterol) were found to be positively non-significantly associated with risk.

For the food groups that showed an interaction with gender (Table 7.2a), gender specific odds ratios are presented in Table 7.3. For both men and women a nonsignificant inverse association with consumption of fruits was observed, which was stronger for women. Among women, but not among men, a significantly increasing trend was evident for intake of red meat. A similar association was not seen in men. Adjustment for saturated fat intake did not appreciably modify these results and saturated fat intake was therefore not included in the model.

When participants (33 cases and 10 controls) who indicated that they had altered their dietary pattern as a result of gastro-intestinal distress were excluded from the analyses, results did not change appreciably either.

\section{Discussion}

From those products of vegetable and animal origin studied, the consumption of vegetables was found to be inversely associated with colon cancer risk. In addition, for women, a non-significant inverse association was found for fruit consumption, while red meat consumption increased risk.

\section{Methodological considerations}

In each retrospective case-control study, selection and information bias might affect the internal validity. Selection bias in cases may occur, when degree of illness is correlated to participation rate. In this study cases with a worse prognosis according to the Dukes' classification participated less often. Dukes' status was inversely related to vegetable consumption: cases with Dukes' $C$ and $D$ tumors consumed less vegetables than those with Dukes' $A$ and $B$ tumors. If more cases with $C$ and $D$ 
tumors would have participated in the study, we might have found stronger inverse associations for vegetables. Meat consumption was not related to Dukes' status in this study. Participating and non-participating cases did not differ in meat consumption either. Since recall of dietary habits can be influenced by a more severe prognosis or medical treatment influencing appetite, it may be an advantage to have cases with better prognosis participating in the study. Age, gender and urbanization-level from interviewed cases did not significantly differ from those eligible.

In the Netherlands, a vegetable rich diet is related to a healthy life-style in general and a higher socio-economic status. If selection of more health-conscious controls occurred, it might explain the results of this study. However, our population-based control group was comparable to the general population according to the distribution of socio-economic status.

In order to minimize information, cases and controls were interviewed in the same season using a structured dietary history questionnaire. Interviewers were trained by the same experienced dietician, who intensively monitored their interviewing and coding. Each interviewer assessed dietary habits of an similar number of cases and controls. No differences between interviewers were found.

Recall bias might influence the results especially when cases, as a result of their disease, report their usual intake before symptoms occurred or the disease was diagnosed differently from the controls. Differential overreporting could occur if some cases remember consuming more foods in general by concentrating more intensively, which is supported by the observed positive association with total energy intake. However, adjustment for total energy intake could not explain our findings. Social desirability of eating healthy foods, such as vegetables and fruits, might influence recall as well. Since the questionnaire was structured, and the complete dietary pattern and several life-style habits were inquired about, it may be assumed that participants were unaware of the hypothesis tested. Finally, changes of habits as a result of gastro-intestinal distress might also be an important reason for recall bias. However, excluding those who indicated to have changed their dietary habits because of complaints did not change the results importantly.

In conclusion, selection and information bias do not seem to have distorted the internal validity of the study seriously.

\section{Food groups of vegetable origin}

With respect to vegetable consumption, our sludy confirms the results of the majority of other case-control studies on colon cancer which observed inverse associations with at least one vegetable group. ${ }^{2}$ However, most studies reported nonsignificant decreases in risk of approximately 20 to $40 \%$ with higher intakes of 
vegetables. Differences between studies might be a result of different consumption patterns among the populations studied. The consumption of vegetables in our study population is relatively high as compared to other studies, and is also high when compared with the intake among the general Dutch population, which is assessed using a 2-day record. ${ }^{32}$ Although checks have been included in the data entry program to compare the reported total frequency of vegetable consumption with the reported consumption of individual vegetables, this might just be a consequence of the lengthy dietary history method used.

Taking power considerations into account and the fact that the examination of a large number of food items might increase the possibility of chance findings and therefore introduce over-interpretation, we explored the associations with food groups and not of individual food items. Previous studies observed inverse associations between colon cancer risk and green leafy vegetables ${ }^{8}$ and cruciferous vegetables. ${ }^{13,35}$ The majority of vegetables consumed in this population werc cruciferous vegetables and green leafy vegetables.

Vegetable consumption was more strongly related to risk than fruits. This is not in line with the case-control study of Steinmetz and Potter ${ }^{18}$ conducted in Australia. In our study an inverse association with fruit consumption was only observed among women, which is in line with the results for fruits in other ${ }^{12,18}$ but not all ${ }^{9}$ case-control studies.

Potatoes are an important source of vitamin $\mathrm{C}$ and polysaccharides. We observed an inverse association with potato consumption. This is in line with a few other case-control studies, ${ }^{5,21}$ while in some studies an increased risk with potato consumption was found. ${ }^{11,13,18}$ Nevertheless, as potatoes are often consumed as part of the main meal, the observed inverse association might be an underestimation of the true association, because of the associated consumption of meat or the use of fat-laden condiments.

\section{Food groups of animal origin}

Except for a positive association with red meat consumption in women, for food groups of animal origin, only non-significant associations were found. None of the quintile specific OR's nor trends were statistically significant.

A higher consumption of fish or poultry did not importantly decrease colon cancer risk as suggested by other studies. ${ }^{26.27}$ Furthermore, the ratio of red meat to fish and poultry was not associated with risk, which is in line with the findings of an Australian case-control study, ${ }^{27}$ but not with the findings in the Nurses' Health Study. ${ }^{2 h}$

Consumption of dairy products was weakly positively, but non-significantly related to risk in this population. The results of epidemiological studies have been 
controversial with respect to consumption of dairy products; some suggest a nonsignificant positive assuciation, ${ }^{11,27,33}$ while others observe a significant inverse association. ${ }^{111,23}$

The consumption of eggs was not markedly associated with risk in this population. Although the range of egg consumption was similar, an Australian casecontrol study observed an 2.4 fold increase in risk in the uppermost quartile of consumption. ${ }^{27}$ Cholesterol was positively but not significantly related to risk in our study.

An increased risk with red meat consumption was observed among women. Beef and pork were the most frequently consumed types of red meat in this population. Increased risks with higher consumption of red meat have previously been observed in some studies, ${ }^{13.15 .23 .26}$ but not in others, including a cohort study in the Netherlands. ${ }^{24,25}$ Red meat is an important source of saturated fat which has been linked to colon cancer risk in most studies. ${ }^{34}$ Saturated fat was positively but not significantly associated with risk in our study, Besides its fat content, meat might be an important source of a variety of heterocyclic amines, formed during cooking processes. After enzymatic activation, these compounds are found to be potent mutagens shown to induce colon tumors. " Since we did not expect a large heterogeneity in meat preparation in this older population and the assessment of cooking method might be unreliable, we did not explore methods of meat preparation in this study.

This study implies that among women the consumption of red meat relative to vegetables and fruits might be important. Antioxidants or other substances in vegetables and fruits might neutralize the potential initiating or promoting factors which might be present in red meat. ${ }^{18}$

\section{Gender differences}

Gender interactions were observed for the consumption of fruits and red meat. Different findings for men and women might make a chance finding more likely. Moreover, differences in results between genders could be due to a difference in the preciseness of the information on food consumption. Women, however, are more likely to give more precise information on food consumption than men; in this Dutch population women traditionally have a more active role in food purchasing and preparation. However, to minimize recall differences between genders in our study, female spouses were asked to be present at the time of the home interview of theirmale partner. A second explanation for the gender differences might be related to the amount consumed. In this study and in the general Dutch population, women tend to consume more fruits than men. However, women consume less red meat as well. 
The positive association with red meat intake in women was mainly determined by the reference group, with an extremely low consumption of red meat. Excluding this group from the analyses attenuated the odds ratio. It is plausible that the category with the lowest meat consumption differs in other risk factors as well. This explanation does not hold, however, since controls with the lowest as compared to the highest red meat consumption, did not differ importantly for dietary variables other than animal protein (data not shown). Nevertheless, those with the lowest red meat consumption tended to have a more health-conscious life-style, e.g they smoked less, drank less alcohol and used more vitamin supplements. Thirdly, real gender differences may exist in colon cancer aetiology. This is supported by the fact that men and women differ in colon physiology, such as bile acid profiles and colonic $\mathrm{pH}^{36}$ Moreover, epidemiologic studies have shown different demographic patterns of colon cancer for men and women. ${ }^{37}$

In summary, the results of this Dutch case-control study provide further support for a protective role for vegetable consumption in colon cancer risk. With the exception of fruits and red meat in women, it does not provide evidence for important reductions or enhancements in risk with other vegetable or animal products in the Netherlands.

\section{References}

1. Netherlands Cancer Registry. Incidence of cancer in the Netherlands. Second report of the Netherlands Cancer Registry, 1990.

2. Steinmetz KA and Potter JD. Vegetables, fruit and cancer. 1. Epidemiology. Cancer Causes Control 1991;2:325-357.

3. Block G, Patterson B, Subar A. Fruit, vegctables, and cancer prevention: a revicw of the epidemiological evidence. Nutr Cancer 1992;18:1-29.

4. Manousos O, Day NE, Trichopoulos D, Gerovassilis F, Tzonou A, Polychronopoulou A. Diet and colorectal cancer: a case-control study in Greece. Int J Cancer 1983;32:1-5.

5. Macquart-Moulin G, Riboli E, Cornéc J, Charnay B, Berthezìne P, Day N. Case-cuntrol study on colorectal cancer and diet in Marscilles. Int J Cancer 1986:38:183-191.

6. Kune S, Kune GA, Watson IF. Case-control study of dietary ctiological factors: The Melbourne colorectal cancer study. Nutr Cancer 1987;9:21-42.

7. Graham S, Marshall J, Haughey B, et al. Dictary epidemiology of cancer of the colnn in western New York. Am J Epidemiol 1988;128:490-503.

8. La Vecchia C, Negri E, Decarli A, et al. A case-control study of diet and colorectal cancer in northern Italy. Int J Cancer 1988;41:492-498.

9. Slattery ML, Sorenson AW, Mahoney AW, French TK, Kritchevsky D, Street JC. Diet and colon cancer: assessment of risk by fiber type and food source. J Natl Cancer Inst 1988;80:1474-1480.

10. Young TB and Wolf DA. Case-control study of proximal and distal colon cancer and diet in Wisconsin. Int J Cancer 1988;42:167-175.

11. Tuyns AJ, Kaaks R, Haelterman M. Colorectal cancer and the consumption of foods: a casecontrol study in Belgium. Nutr Cancer 1988;11:189-204.

12. Lee HP, Gourley L, Duffy SW, Estève J, Lee J, Day NE. Colorectal cancer and diet in an 
Asian population-a case-control study among Singapore Chinese. Int J Cancer 1989;43:10071016.

13. Benito E, Ohrador A, Stiggelbout A, et al. A population-based case-control study of colorectal cancer in Majorca. I. Dietary factors. Int J Cancer 1990;45:69-76.

14. Hu J, Liyu Y, Yu Y, et al. Diet and cancer of the colon and rectum: a case-control study in China. Int J Epidemiol 1991:20:362-367.

15. Bidoli E, Franceschi S, Talamini R, Barra S, La Vecchia C. Food consumption and cancer of the colon and rectum in North-Eastern Italy. Int J Cancer 1992;50:223-229.

16. Thun MJ, Calle EE, Namboodiri MM, et al. Risk factors of fatal colon cancer in a large prospective study. J Natl Cancer Inst 1992;19:1491-1500.

17. Zaridze D, Filipchenko V, Kustov V, Serdyuk V, Duffy S. Diet and colorectal cancer: results of two case-control studies in Russia. Eur J Cancer 1993;1:112-115.

18. Steinmetz KA and Potter JD. Food group consumption and colon cancer in the Adelaide case-control study. I. Vegetables and fruit. Int J Cancer 1993;53:711-719.

19. Miller AB, Howe GR, Jain M, Craib KJP, Harrison L. Food items and food groups as risk factors in a case-control study of diet and colorectal cancer. Int J Cancer 1983:32:155-161.

20. Tajima $\mathrm{K}$ and Tominaga $\mathrm{S}$. Dietary habits and gastro-intestinal cancers: a comparative casecontrol study of stomach and large intestinal cancers in Nagoya, Japan. Jpn J Cancer Res 1985:76:705-716.

21. Iscovich JM, L'Abbé KA, Castelleto $R$, et al. Colon cancer in Argentina. I: risk from intake of dietary items. Int J Cancer 1992;51:851-857.

22. Shibata A, Paganini-Hill A, Ross RK, Henderson BE. Intake of vegetables, fruits, betacarotene, vitamin $\mathrm{C}$ and vitamin supplements and cancer incidence among the elderly: a prospective study. Brit J Cancer 1992;66:673-679.

23. Peters RK, Pike MC, Garabrant D, Mack TM. Diet and colon cancer in Los Angeles County, California. Cancer Causes Control 1992;3:457-473.

24. Goldbohm RA, van den Brandt PA, van 't Veer P, et al. A prospective cohort study on the relation between meat consumption and the risk of colon cancer. Cancer Res 1994;54:718723.

25. Bostick RM, Potter JD, Kushi LH, et al. Sugar, meat, and fat intake, and non-dietary risk factors for colon cancer incidence in Iowa women (United States). Cancer Causes Control $1994 ; 5: 38-52$.

26. Willett WC, Stampfer MJ, Colditz GA, Rosner BA, Speizer FE. Relation of meat, fat, and fiber intake to the risk of colon cancer in a prospective study among women. N Engl J Med 1990;323:1664-1672.

27. Steinmetz KA and Potter JD. Food group consumption and colon cancer in the Adelaide case-control study. II. Meat, poultry, seafood, dairy foods and eggs. Int J Cancer 1993;53:720-727.

28. Bingham SA. Diet and large bowel cancer. J Roy Soc Med 1990;83:420-422.

29. Sorenson AW, Slattery ML, Ford MH. Calcium and colon cancer: a revicw. Nutr Cancer 1988;11:135-145.

30. Nevo tabel. Dutch food composition table 1989-90. The Haque, Netherlands: Voorlichtingsbureau voor de Voeding, Stichting Nevo 1989.

31. Willett WC and Stampfer MJ. Total energy intake: implications for epidemiological analyses. Am J Epidemiol 1986; 124:17-27.

32. Anonymus. Wat eet Nederland 1987-1988? Rijswijk. Ministerie van Welzijn, Volksgezondheid en Cultuur en Ministerie van Landbouw en Visserij, 1988.

33. Negri E, LaVecchia C, D'Avanzo B, Francheschi S. Calcium, dairy products and colorectal cancer. Nutr Cancer 1990;13:255-262.

34. Potter JD, Slattery ML, Bostick RM, Gapstur SM. Colon cancer: a review of the epidemiology. Epidemiol Rev 1993;15:499-545.

35. Turesky RJ, Lang N, Butler MA, et al. Metabolic activation of carcinogenic heterocyclic aromatic amines by human liver and colon. Carcinogenesis 1991;12:1417-1422.

36. Lampe JW, Fredstrom SB, Slavin JL, Potter JD. Sex differences in colonic function: a 
randomized trial. Gut 1993;34:531-536.

37. DeCosse JJ, Ngoi SS, Jacobson JS, Cennerazzo WJ. Gender and colorectal cancer. Eur J Cancer Prev 1993;2:105-115. 


\section{$-$}




\section{Chapter 8}

\section{Fermented dairy products, calcium and colorectal cancer in the Netherlands Cohort Study}




\section{Abstract}

Experimental studies suggest that an increased consumption of fermented dairy products and calcium might decrease the risk of colorectal cancer.

The association between fermented dairy products, dietary calcium and colorectal cancer risk was investigated in a population with a wide variation in intake of dairy products. The Netherlands Cohort Study on diet and cancer (NLCS) started in 1986 when 120,852 Dutch men and women, aged 55-69 years, filled out a questionnaire on dietary patterns and life-style. The present analysis is based on 3.3 years of follow-up and included 215 incident cases of colon cancer and 111 incident cases of rectal cancer, excluding cases diagnosed in the first year of follow-up.

After adjustment for potential confounding variables, colorectal cancer risk was weakly inversely associated with the consumption of fermented milk (Relative Rates $(\mathrm{RR})$ in the highest category of intake compared to non-users $=0.89,95 \%$ Confidence Intervals $(\mathrm{CI})=0.60-1.33)$, unfermented milk $(\mathrm{RR}=0.86,95 \% \mathrm{CI}=$ 0.57-1.29), and cheese ( $\mathrm{RR}=0.88,95 \% \mathrm{CI}=0.59-1.33)$. However, categoryspecific relative rates, and tests for trends were not statistically significant. For fermented milk, the inverse association was limited to colon cancer ( $R R=0.70$, 95\% $\mathrm{CI}=0.43-1.15$, trend $\mathrm{p}=0.33$ ).

In crude and multivariate models, total dietary calcium intake (highest vs. lowest quintile $\mathrm{RR}=0.92,95 \% \mathrm{CI}=0.64-1.34)$ and calcium from fermented dairy products $(\mathrm{RR}=1.14,95 \% \mathrm{CI}=0.77-1.68)$ were not significantly associated with colorectal cancer risk. Calcium from unfermented dairy products was inversely associated with rectal cancer risk $(R R=0.55,95 \% \mathrm{CI}=0.30-1.04$, trend $\mathrm{p}=0.03)$.

After 3.3 years of follow-up, these data are not consistent with a substantially decreased risk of colorectal cancer with increased intake of fermented dairy products and dietary calcium. 


\section{Introduction}

Colorectal cancer is one of the major types of cancer in Western society. In the Netherlands, yearly about 48 new cases of colorectal cancer ( 30 colon, 18 rectum) are diagnosed per 100,000 men and 49 cases per 100,000 women (35 colon, 14 rectum). Colorectal cancer is the third most common cancer in Dutch men and the second most common cancer in Dutch women. ${ }^{1}$ As its incidence is still rising, treatment is difficult, and mortality remains high, emphasis should be placed on preventive measures. Besides dietary recommendations against cancer in general, such as a higher consumption of vegetables and fruits, ${ }^{2}$ other relatively simple and feasible dietary changes might add to the prevention of colorectal cancer.

The possible protective role of fermented dairy products such as yogurt, buttermilk and cheese, originally proposed by Metchnikoff ${ }^{3}$ in the beginning of this century, has regained attention in the past decade. Establishment of certain lactobacilli in the gastro-intestinal tract could contribute to the stabilization of the colonic flora, and exert beneficial effects on the host. In recent experiments, the activity of carcinogen-producing faecal enzymes was decreased in subjects supplemented with Lactobacillus cultures ${ }^{4,5}$ and in vitro studies with human lymphocytes suggest that lactobacilli stimulate the immune system locally, as well as systemically. ${ }^{6.7}$

In addition to these mechanisms mediated by microorganisms, fermented dairy products contribute substantially to our daily calcium intake. In the Netherlands, about $70 \%$ of calcium intake is of dairy origin, half of which is from fermented dairy products. It is hypothesized that calcium ${ }^{6}$ or, more recently, that calcium phosphate ${ }^{9}$ binds free fatty acids and bile acids, thereby reducing the effective toxic dose to the colonic epithelial cells and their subsequent proliferative response. Calcium might also directly influence cell proliferation by inducing cell differentiation. ${ }^{10}$

Although several epidemiological studies have investigated the relationship between dairy product consumption, calcium intake and colorectal cancer (e.g. ${ }^{11-22}$ ) or colorectal polyps (e.g. ${ }^{23}$ ), only few addressed the association with fermented dairy products. ${ }^{14,16,17,18,20,23}$ In two population-based case-control studies on colon cancer an inverse association was observed for yogurt (Odds Ratio $(\mathrm{OR})=0.83$ for 10 servings per month, 95\% Confidence Intervals $(\mathrm{CI})=0.70-0.98)^{20}$ and cultured milk consumption $(\mathrm{OR}=0.65,95 \% \mathrm{CI}=0.41-1.01),{ }^{16}$ adjusted for potential confounding variables. In two companion American prospective studies, the 19801988 follow-up of the Nurses' Health Study (NHS: 121,700 women) and the 19861990 follow-up of the Health Professionals Follow-Up Study (HPFS: 51,529 men), 
a non-significant inverse association with yogurt consumption and colorectal polyps was found (RR for more than 4 times a week 1 cup vs. almost never NHS $=0.60$, $95 \% \mathrm{CI}=0.30-1.18 ;$ HPFS $=0.66,95 \% \mathrm{CI}=0.28-1.46)$, which diminished in the HPFS after adjustment for covariates $(\mathrm{RR}=0.89){ }^{23}$

Although cheese consumption contributes significantly to saturated fat intake, in several case-control studies ${ }^{14,16,18}$ and one prospective study ${ }^{17}$ the consumption of this product was not strongly associated with colorectal cancer risk (Relative Rates (RR) $0.9,0.7,1.1$ and 1.1 respectively).

The studies mentioned above have mainly been conducted in countries in which the consumption of yogurt or cultured milk is not integrated in traditional food habits. In countries in which the consumption of fermented milk is high and heterogeneous, the comparison of risks between high and low consumption categories would be most powerful. The Dutch have a longstanding tradition of fermented dairy product consumption (e.g. per capita annual consumption of yogurt in the Netherlands is $18.9 \mathrm{~kg}$ vs. $2.1 \mathrm{~kg}$ in the United States). ${ }^{24}$ In two case-control studies conducted in the Netherlands inverse associations between breast cancer ${ }^{25}$ and cancer of the exocrine pancreas ${ }^{26}$ on the one hand and fermented dairy product consumption on the other were observed. We studied the association between these products, calcium and colorectal cancer prospectively in the ongoing Netherlands Cohort Study (NLCS) on diet and cancer. ${ }^{27}$

\section{Methods}

The cohort characteristics and the method for cancer follow-up have been described. ${ }^{27}$ Briefly, the study was initiated in 1986 when 58,279 men and 62,573 women aged 55 to 69 completed a self-administered baseline questionnaire inquiring after food habits and potential confounding factors. Following the casecohort approach for analysis of the data, a subcohort of 3,500 persons (1,688 men, 1,812 women) was randomly sampled from the baseline cohort and followed up for vital status to estimate the person time contributed by the entire cohort. No subcohort members were lost to follow-up. Incident cancer cases occurring in the cohort were identified by record linkage to cancer registries and a nation-wide pathology register. ${ }^{28}$ The analysis in this report was restricted to 3.3 years of followup from Scptember 1986 (baseline) to December 1989. The completeness of cancer follow-up was estimated to be $95 \%{ }^{29}$

\section{Food frequency questionnaire}

The semi-quantitative food frequency questionnaire included 150 food items concentrating on habitual food and beverage intake during the preceding year. ${ }^{30}$ The 
daily amounts of 9 dairy items were estimated from the number of glasses (milk, chocolate milk, buttermilk), number of cups (yogurt, curds, custards with and without dietary fiber) or number of sandwiches filled (cheese and low-fat cheese). In addition, consumption of cheese as a meat substitute with the hot meal was asked for.

The questionnaire was validated against a 9-day dietary record. ${ }^{30}$ The sex- and energy- adjusted Pearson coefficients of correlation for dietary calcium was 0.62. The Spearman coefficient of correlation for milk and milk products was 0.60 and for cheese 0.61 . To minimize observer bias in coding and interpretation of the data, questionnaires were key-entered twice and processed blinded with respect to case/subcohort status.

\section{Data analysis}

Subjects who reported a history of cancer other than skin cancer in the baseline questionnaire were excluded. A total of 3,346 subcohort members (1,630 men, 1,716 women) and 478 incident cases (312 colon, 166 rectum; 258 men, 220 women) remained available for analysis. Furthermore, $7 \%$ of these subjects were excluded because of incomplete or inconsistent dietary data. ${ }^{29}$ Therefore, 3,111 subcohort members and 443 colorectal cancer cases (293 colon, 150 rectum), 12 of which were members of the subcohort, were included in the analysis. As subclinical symptoms of colorectal cancer may influence dietary habits before diagnosis, data were analyzed without taking the first year of follow-up into consideration (3,083 subcohort members, 215 colon cancer and 111 rectal cancer cases).

Categories of dairy product intake were based on the subcohort distribution with non-users taken as the reference. Additional analyses were conducted excluding non-users and taking the lowest category of intake as the reference. For nutrient intakes, quintiles based on the subcohort distribution were used in the analysis. Since subjects tend to skip items they do not consume, ${ }^{31}$ persons with missing data on a relevant dairy product were treated as non-users. We verified this assumption by conducting analyses including a variable indicating those with missing data on one of the specific foods.

In this cohort, the major fermented dairy products were buttermilk (39\% of total consumption in grams), yogurt (39\%), fat cheese (16\%) and curds (6\%). Because of their low contribution, curds are not taken into account in analyses on products. The fermented milks (yogurt and buttermilk) which differ from cheese with respect to their consumption pattern, were treated as one food group. With respect to cheese, analyses were restricted to full-fat cheese (95\% hard cheese) which accounts for about $90 \%$ of cheese consumption in this cohort. 
In this population, the consumption of yogurt and buttermilk was positively, although not strongly, correlated $(r=0.13)$.

Mean daily nutrient intake was calculated from mean food intakes using the computerized Dutch food composition table. ${ }^{32}$ Energy-adjusted nutrient intakes were based on residuals from the regression of nutrient intake on total energy intake. ${ }^{33}$ Since, exact amounts of calcium in the various supplements used were not available, calcium supplement use (alone $(91 \%)$ or in combination with vitamin D) is examined as a dichotomous variable (use yes or no). Since less than $1 \%$ of the subcohort uses specific vitamin D supplements, these supplements were not taken into account in these analyses.

The case-cohort approach was used for data analysis. ${ }^{34}$ Specific programs were developed to account for the additional variance introduced by estimating the person time-at-risk for the subcohort instead of for the entire cohort. ${ }^{29}$

Apart from the known risk factors for colorectal cancer (age, family history of large bowel cancer, history of gallbladder surgery ${ }^{35}$ ), the following variables were evaluated as potential confounders using multivariate models: smoking, level of education, any vitamin supplement use, intake of energy and energy adjusted intake of fat and dietary fiber. Cases with missing data on covariates were excluded from the multivariate analyses.

Vitamin D intake through sun exposure and from foods could not be adequately assessed and was not taken into account in these analyses.

In addition, analyses were conducted for colon and rectal cancer separately.

\section{Results}

Daily intake of yogurt and buttermilk together (median) ranged from $0 \mathrm{~g} /$ day in the lowest to $267 \mathrm{~g} /$ day in the highest category of intake. For hard cheese consumption, the intake ranged from 0 in the lowest to $37 \mathrm{~g} /$ day in the highest category. Intake of calcium ranged from $546 \mathrm{mg}$ in the lowest quintile to $1,344 \mathrm{mg}$ in the highest quintile; after energy adjustment these medians were 581 and $1,286 \mathrm{mg} /$ day, respectively.

Table 8.1 shows various characteristics of subcohort members according to high and low intake of fermented milk and calcium.

Those who never consumed yogurt or buttermilk did not differ largely regarding age, energy intake and calcium/ phosphate ratio from those in the highest category of intake. Energy-adjusted intake of fat was higher, while energy-adjusted dietary fiber intake was lower in the lowest category of fermented milk consumption. 
Table 8.1 Characteristics of subcohort members $(n=3,111)$ according to high and low intake of fermented milk ${ }^{a}$ and calcium.

Fermented milk ${ }^{a}$

Calcium

\begin{tabular}{|c|c|c|c|c|}
\hline Variables & Non-users & $\begin{array}{l}\text { Highest } \\
\text { category of } \\
\text { intake }\end{array}$ & $\begin{array}{l}\text { Lowest } \\
\text { quintile of } \\
\text { intake }\end{array}$ & $\begin{array}{l}\text { Highest } \\
\text { quintile of } \\
\text { intake }\end{array}$ \\
\hline Age $\pm S D$ & $61.8 \pm 4.2$ & $61.5 \pm 4.2$ & $61.5 \pm 4.1$ & $61.2 \pm 4.2$ \\
\hline Gender ( $\%$ men) & 60.6 & 39.2 & 49.0 & 49.0 \\
\hline \multicolumn{5}{|c|}{ Dietary factors (mean \pm SD) } \\
\hline Fermented milk (g/day) & 0 & $303 \pm 116$ & $34 \pm 51$ & $165 \pm 163$ \\
\hline Hard cheese (g/day) & $17 \pm 18$ & $21 \pm 19$ & $8 \pm 8$ & $33 \pm 24$ \\
\hline Unfermented milk (g/day) & $114 \pm 162$ & $91 \pm 134$ & $28 \pm 49$ & $233 \pm 204$ \\
\hline Calcium (mg/day) ${ }^{b}$ & $814 \pm 281$ & $1,146 \pm 272$ & $633 \pm 135$ & $1,300 \pm 248$ \\
\hline Energy ( $\mathrm{kJ} /$ day) & $8,102 \pm 2,282$ & $7,967 \pm 2,100$ & $6,738 \pm 1,790$ & $9,356 \pm 2,31$ \\
\hline Total fat $(\mathrm{g} / \text { day })^{b}$ & $86 \pm 17$ & $79 \pm 16$ & $85 \pm 15$ & $82 \pm 18$ \\
\hline Dietary fiber (g/day $)^{b}$ & $26 \pm 7$ & $29 \pm 7$ & $26 \pm 6$ & $28+8$ \\
\hline Calcium/phosphate ratio & $0.6 \pm 0.1$ & $0.7 \pm 0.1$ & $0.5 \pm 0.1$ & $0.8 \pm 0.1$ \\
\hline
\end{tabular}

\section{Medical and life-style factors}

$\begin{array}{lcccc}\text { Body mass index }\left(\mathrm{kg} / \mathrm{m}^{2}\right) & 25.0 \pm 3.2 & 25.3 \pm 3.2 & 25.1 \pm 3.3 & 24.9 \pm 2.9 \\ \text { Gallbladder surgery }(\%) & 7.6 & 11.7 & 10.1 & 9.4 \\ \text { Family history of colorectal } & & & & \\ \text { Cancer }(\%) & 5.0 & 5.7 & 5.1 & 5.5 \\ \text { High level of education }(\%) & 11.4 & 15.4 & 10.0 & 13.3 \\ \text { Current smokers }(\%) & 42.1 & 21.6 & 35.6 & 27.9 \\ \text { Calcium supplement users }(\%)^{c} & 1.8 & 5.5 & 2.2 & 4.8\end{array}$

\section{Buttermilk and yogurt.}

Adjusted for total energy intake by regression analysis.

Includes only calcium $(91 \%)$ or calcium in combination with vitamin D or magnesium.

Women consumed yogurt and buttermilk more frequently than men (Table 8.1; median daily intake among users: women $96 \mathrm{~g}$, men $79 \mathrm{~g}$ ), whereas cheese consumption was similar for both genders (median daily intake among users $19 \mathrm{~g}$ ). Body mass index and a positive family history for colorectal cancer did not differ appreciably between the two categories of consumption. Among the highest category of consumption, a history of gallbladder surgery was reported more frequently, and educational level was higher. The non-user group included more current smokers. Calcium supplements were used more frequently by those with the highest consumption.

Hard cheese consumption was positively associated with energy intake and educational level (data not shown). 
Table 8.2 Relative rates of colorectal cancer according to consumption of dairy products. ${ }^{a}$

\begin{tabular}{|c|c|c|c|c|c|}
\hline \multirow{2}{*}{$\begin{array}{l}\text { Average daily } \\
\text { intake }(\mathrm{g})\end{array}$} & \multirow{2}{*}{$\begin{array}{l}\text { Subcohort } \\
\text { members }\end{array}$} & \multirow[t]{2}{*}{ Cases } & \multicolumn{2}{|c|}{ Relative rates $(95 \div \% \mathrm{Cl})$} & \multirow{2}{*}{$\begin{array}{l}\chi^{2} \text { for } \\
\text { trend } b \\
\text { (p-value) }\end{array}$} \\
\hline & & & $\begin{array}{l}\text { Age-, gender- } \\
\text { adjusted }\end{array}$ & Multivariate $^{c}$ & \\
\hline \multicolumn{6}{|c|}{ Fermented milk ${ }^{d}$} \\
\hline non-users & 719 & 85 & 1.00 & 1.00 & $0.10(0.75)$ \\
\hline$<30$ & 561 & 49 & $0.82(0.56-1.20)$ & $0.83(0.56-1.21)$ & \\
\hline $30-90$ & 569 & 67 & $1.07(0.76-1.52)$ & $1.10(0.77-1.56)$ & \\
\hline $90-180$ & 732 & 76 & $0.91(0.65-1.28)$ & $0.93(0.66-1.31)$ & \\
\hline$\geq 180$ & 502 & 49 & $0.90(0.61-1.32)$ & $0.89(0.60-1.33)$ & \\
\hline \multicolumn{6}{|l|}{ Hard cheese } \\
\hline non-users & 394 & 48 & 1.00 & 1.00 & $0.32(0.57)$ \\
\hline$<15$ & 1,173 & 104 & $0.69(0.48-0.99)$ & $0.67(0.47-0.97)$ & \\
\hline $15-30$ & 860 & 107 & $0.90(0.62-1.30)$ & $0.94(0.65-1.37)$ & \\
\hline$\geq 30$ & 656 & 67 & $0.82(0.55-1.21)$ & $0.88(0.59-1.33)$ & \\
\hline \multicolumn{6}{|c|}{ Unfermented milk ${ }^{\mathrm{e}}$} \\
\hline non-users & 1,126 & 130 & 1.00 & 1.00 & $0.70(0.40)$ \\
\hline$<120$ & 819 & 77 & $0.79(0.58-1.07)$ & $0.81(0.59-1.09)$ & \\
\hline $120-240$ & 785 & 83 & $0.90(0.66-1.21)$ & $0.90(0.67-1.22)$ & \\
\hline$>240$ & 353 & 36 & $0.85(0.57-1.26)$ & $0.86(0.57-1.29)$ & \\
\hline
\end{tabular}

a Excluding first year of follow-up.

$b$ Multivariate model.

c Adjusted for age, gender, family history of colorectal cancer, intake of energy, energyadjusted intake of fat and dietary fiber, Body mass index, history of gallbladder surgery.

d Buttermilk and yogurt.

e Whole milk and skim/low-fat milk.

(alcium intake was positively associated with energy intake, but no important associations of calcium were observed with age, gender, energy-adjusted intake of fat and dietary fiber, body mass index, family history of colorectal cancer, history of gallbladder surgery, educational level and smoking status (Table 8.1). The calcium/phosphate ratio was higher and calcium supplements (alone or in combination with vitamin D) were more frequently used among those with the highest dietary calcium intake. Previous publications provide differences between cases and subcohort members for several non-dairy variables. ${ }^{36,37}$

Table 8.2 shows the relative rates (RR) of colorectal cancer according to dairy product consumption. After adjustment for age and gender, consumption levels for fermented milk, cheese and unfermented milk were weakly inversely related to colorectal cancer risk. However, for fermented and unfermented milk, none of the category-specific relative rates nor trends were statistically significant. For yogurt and buttermilk separately similar non-significantly decreased risks were observed: $\mathrm{RR}$ for highest vs. lowest intake was $0.89(95 \% \mathrm{Cl}=0.65-1.21)$ for yogurt and 0.94 
(95\% CI $=0.68-1.30)$ for buttermilk. The associations with fermented dairy products tended to be most pronounced in women: RR for highest vs. lowest intake was $0.81(95 \% \mathrm{CI}=0.46-1.44)$ for fermented milk and $0.61(95 \% \mathrm{Cl}=0.34-1.09)$ for hard cheese.

Adjustment for other potentially confounding variables in multivariate analysis did not change the results appreciably (Table 8.2). Education level, supplement use and smoking status were not included in the models since they did not affect the estimates. Additional adjustment for total calcium intake or inclusion of cases diagnosed during the first year of follow-up did not change the results either (data not shown).

The inverse association with fermented milk was restricted to colon cancer (multivariate RR for highest vs. lowest intake: colon $=0.70,95 \% \mathrm{CI}=0.43-1.15$, $\chi^{2}$ trend $=0.23 ;$ rectum $=1.38,95 \% \mathrm{CI}=0.74-2.57, \chi^{2}$ trend $=0.25$ ).

Former analyses assume that those who skipped relevant dairy items in the questionnaire were non-users. When analyses were repeated, including an indicator variable for these subjects, RR estimates for fermented milk, checse and unfermented milk did not change appreciably (RRs 0.90, 0.85 and 0.95 respectively). Excluding non-users from the analyses and choosing the lowest category of consumption as the reference altered the RRs slightly (RRs $0.96,1.21$ and 1.10 respectively).

Table 8.3 presents the observed relative rates for energy-adjusted dietary calcium intake and calcium from different dietary sources. After adjustment for age and sex and in multivariate models, total dietary calcium and calcium from fermented dairy products were not strongly associated with colorectal cancer risk, while calcium from unfermented dairy products tended to be inversely and calcium from non-dairy products positively associated. The non-significant inverse association with calcium from unfermented milk and the positive association with non-dairy calcium were most pronounced for rectal cancer (RR highest vs. lowest quintile for unfermented dairy calcium $=0.55,95 \% \mathrm{CI}=0.30-1.04, \chi^{2}$ trend $=4.57 ; \quad \mathrm{RR}$ for non-dairy calcium $=2.32 ; 95 \% \mathrm{CI}=1.02-5.28, \chi^{2}$ trend $\left.=5.67\right)$.

Calcium supplement use was not assuciated with risk (multivariate RR of users vs. non-users $=0.95,95 \% \mathrm{CI}=0.50-1.78$ ).

When analyses were conducted in terms of the calcium/phosphate ratio (RR per difference of $0.1=0.94,95 \% \mathrm{CI}=0.85-1.04$ ) or stratified according to gender, results remained similar (data not shown). 
Table 8.3 Relative rates of colorectal cancer for quintiles of dietary calcium intake. ${ }^{a}$

\begin{tabular}{|c|c|c|c|c|c|c|}
\hline \multirow[t]{2}{*}{ Nutrient } & \multicolumn{5}{|c|}{ Level of consumption } & \multirow{2}{*}{$\begin{array}{l}\chi^{2} \text { for trend } \\
\text { (p-value) }\end{array}$} \\
\hline & Q1 & Q2 & Q3 & Q4 & Q5 & \\
\hline \multicolumn{7}{|l|}{ Total dietary calcium ${ }^{b}$} \\
\hline number in subcohort & 623 & 619 & 622 & 627 & 620 & \\
\hline $\begin{array}{l}\text { median intake in subcohort, } \\
\mathrm{mg} / \text { day }\end{array}$ & 596 & 768 & 893 & 1,032 & 1,288 & \\
\hline age- and gender-adjusted RR & 1.00 & 0.83 & 0.96 & 0.92 & 0.93 & $0.03(0.87)$ \\
\hline multivariate $\mathrm{RR}^{c}$ & 1.00 & 0.84 & 0.96 & 0.93 & 0.92 & $0.02(0.89)$ \\
\hline$(95 \% \mathrm{Cl})$ & & $(0.58$ & $(0.67$ & 9) $(0.64$ & 6) $(0.64-1.34)$ & \\
\hline
\end{tabular}

\begin{tabular}{|c|c|c|c|c|c|c|}
\hline \multicolumn{7}{|l|}{ Calcium from non-dairy } \\
\hline number of cases & 91 & 82 & 95 & 93 & 82 & \\
\hline number in subcohort & 621 & 625 & 622 & 621 & 622 & \\
\hline $\begin{array}{l}\text { median intake in subcohort, } \\
\mathrm{mg} / \text { day }\end{array}$ & 238 & 284 & 318 & 356 & 417 & \\
\hline age- and gender-adjusted RR & 1.00 & 1.14 & 1.51 & 1.28 & 1.25 & $1.77(0.18)$ \\
\hline multivariate $\mathbf{R R}^{c}$ & 1.00 & 1.27 & 1.82 & 1.64 & 1.77 & $6.56(0.01)$ \\
\hline$(95 \% \mathrm{CI})$ & & $(0.83-1.92)$ & $(1.21-2,74)$ & $(1.05-2.56)$ & $(1.08-2.90)$ & \\
\hline \multicolumn{7}{|l|}{$\begin{array}{l}\text { Calcium from fermented } \\
\text { dairy products }\end{array}$} \\
\hline number of cases & 81 & 87 & 94 & 95 & 86 & \\
\hline number in subcohort & 625 & 620 & 621 & 628 & 617 & \\
\hline $\begin{array}{l}\text { median intake in subcohort, } \\
\text { mg/day }\end{array}$ & 64 & 181 & 287 & 394 & 634 & \\
\hline age- and gender-adjusted RR & 1.00 & 0.96 & 1.20 & 1.10 & 1.07 & $0.41(0.52)$ \\
\hline multivariate $\mathrm{RR}^{c}$ & 1.00 & 1.01 & 1.29 & 1.18 & 1.14 & $0.98(0.32)$ \\
\hline$(95 \% \mathrm{CI})$ & & $(0.69-1.48)$ & $(0.89-1.88)$ & $(0.80-1.72)$ & $(0.77-1.68)$ & \\
\hline
\end{tabular}

Calcium from unfermented dairy products

number of cascs

number in subcohort

$\begin{array}{rrrrr}110 & 85 & 78 & 93 & 77 \\ 622 & 625 & 616 & 624 & 624 \\ 45 & 150 & 238 & 345 & 540\end{array}$

median intake in subcohort,

150

238

540

miday

$\begin{array}{lllllll}\text { age- and gender-adjusted RR } & 1.00 & 0.78 & 0.70 & 0.81 & 0.72 & 2.65(0.10) \\ \text { multivariate RR } \mathrm{RR}^{\mathrm{C}} & 1.00 & 0.78 & 0.69 & 0.79 & 0.71 & 2.60(0.11) \\ (95 \% \mathrm{Cl}) & & (0.54-1.11) & (0.48-1.01) & (0.55-1.14) & (0.48-1.05) & \end{array}$

a Excluding first year of follow-up.

$b$ Adjusted for total energy intake by regression analysis. Total dietary calcium does not include calcium supplements.

c Adjusted for age, gender, family history of colorectal cancer, intake of energy, energy-adjusted intake of fat and dietary fiber, body mass index, history of gallbladder surgery.

d Yogurt, buttermilk, cheese, curds. 


\section{Discussion}

These data do not support a protective role of fermented dairy products or calcium in colorectal cancer risk. Although risks of colon and rectal cancer were inversely associated with fermented milk consumption and calcium intake from unfermented dairy products respectively, none of the relative rates were significantly different from unity.

A potential drawback of this study is the short follow-up period, i.e. 3.3 years. Especially when gastro-intestinal complaints in the time span before diagnosis would have changed dairy product intake, this could have altered the associations. However, the similarity of results observed in the data with and without cases diagnosed within the first year of follow-up does not support this possibility. Our questionnaire inquired after dietary patterns in the preceding year and might not be representative over a longer period of time. However, this is a population of elderly people, who are usually considered to have stable food patterns. This stability is confirmed by a repeatability study, in which the food frequency questionnaire was readministered in five consecutive years after baseline assessment. It indicated fairly stable nutrient intakes over time (unpublished data). Furthermore, the consumption of these sour fermented milk products is strongly related to preference, which makes it reasonable to assume that the intake of these products does not change dramatically over the years.

The absence of an observed association is not likely to be explained by insufficient contrast in the population. In our cohort, the intake of yogurt and buttermilk varied from zero in the lowest category to a median of $267 \mathrm{~g} /$ day in the highest one according to the questionnaire data; and for cheese from zero in the lowest to $37 \mathrm{~g} /$ day in the highest category. Despite a lower per capita intake ${ }^{24}$ and presumably a smaller range of intake in the United States, in two American colon cancer case-control studies ${ }^{16,20}$ a significant protective effect was found for cultured milk and yogurt. However, no important associations between fermented dairy products and colorectal polyps were found in the Nurses' Health Study and the Health Professionals Follow-up Study, two American prospective studies. ${ }^{23}$ In a Dutch breast cancer case-control study (133 cases, 289 population controls), women with a daily intake of $225 \mathrm{~g}$ of fermented milk had a 45\% lower risk ( $\mathrm{OR}=0.55$, $95 \% \mathrm{CI}=0.24-1.27)$ than non-users. ${ }^{25}$ An odds ratio of $0.49(95 \% \mathrm{CI}=0.14-1.76)$ was found for those women who consumed 20 to $40 \mathrm{~g}$ of cheese per day compared to non-users. ${ }^{25}$ In a Dutch case-control study on pancreatic cancer, an inverse association with fermented milk products (highest vs. lowest quintile of intake $\mathrm{OR}=0.37, \mathrm{p}<0.05)$ and cheese $(\mathrm{OR}=0.44, \mathrm{p}>0.1)$ was observed. ${ }^{26}$ 
The apparent contradiction of results from epidemiological studies and experimental studies examining lactobacilli is intriguing, ${ }^{47}$ but might be explained by differences in bacterial strains. In most experiments Lactobacillus acidophilus is used, which passes the stomach and survives the gastro-intestinal tract, whereas $L$. bulgaricus, Streptococcus thermophilus, S. lactis and $S$. tremor, which are most frequently used in yogurt and buttermilk, are less resistant to acidic conditions in the stomach. ${ }^{38}$

Compared to fermented dairy products, the association between calcium consumption and colorectal cancer risk has been studied more often in epidemiology. However, results are not consistent: some studies found an inverse association, ${ }^{11 \cdot 13,19,20}$ while others found only a weak non-significant inverse association ${ }^{17,22,39}$ or no association at all. ${ }^{18}$ Until now, only a few prospective studies, using a validated food frequency questionnaire, investigated the association between calcium intake and colon cancer ${ }^{22}$ or colorectal adenomas. ${ }^{23}$ In the lowa Women's Health Study, "' after 4 years of follow-up, higher intakes of total calcium (including supplements) and milk products were associated with a $20-30 \%$ reduction in colon cancer risk. However, the multivariate adjusted estimates and the $\chi^{2}$ for trend were not statistically significant and dietary calcium was not associated with risk $(\mathrm{RR}=0.95 ; 95 \% \mathrm{Cl}=0.57-1.61)$. In the NHS and HPFS no associations with total or dietary calcium and colorectal polyps were observed (RR for highest vs. lowest intake of total calcium: $\mathrm{NHS}=1.17, \quad 95 \% \mathrm{CI}=0.81-1.69 ; \quad \mathrm{HPFS}=1.13$, $95 \% \mathrm{CI}=0.76-1.66) .^{23}$

Our results apply to an elderly population. Since calcium metabolism in pre- and postmenopausal women might be different, our results might not be applicable to a younger generation. However, in the Nurses' Health Study, which covers a younger age group, no association between the occurrence of colorectal adenomas and calcium intake was observed. ${ }^{23}$

Median calcium intake ranged from $546 \mathrm{mg}$ per day in the lowest quintile to $1344 \mathrm{mg}$ per day in the highest quintile. According to Newmark et al.'s calculations, ${ }^{8}$ a daily intake of $1,500 \mathrm{mg}$ calcium is necessary for individuals with a high-fat (150 g/day), high-phosphate $(1,500 \mathrm{mg} /$ day) diet to neutralize the fatty acid and bile acid concentrations in the bowel. This implies that a substantial proportion of participants in our study should have been consuming an adequate amount of calcium to experience the biological effects, especially since fat intake was lower than used in the calculations of Newmark et al. ${ }^{8}$

The differences in relative risk observed for calcium from different dietary sources might be a chance finding. The range of calcium intake from non-dairy products is about one third of that from dairy products, resulting in less stable 
estimates. Furthermore, the non-dairy group is a mixture of different food items, such as vegetables, coffee and tea, which makes these findings difficult to interpret.

Exposure to sunlight, the most important source of vitamin D, was not taken into account, since no validated method of sunlight exposure assessment using a selfadministered questionnaire was available. Since our national nutrient database did not include vitamin $D$ and supplements only including vitamin $D$ are rarely used in this cohort, vitamin D intake could not be studied. In contrast to the United States, Dutch dairy products are not supplemented with vitamin $D$.

In summary, the consumption of fermented dairy products and the intake of dietary calcium are not significantly associated with colorectal cancer risk in this elderly population with a relatively wide variation in dairy product consumption. Although a weak non-significant inverse association with colon cancer was observed, the protective effect of fermented dairy products as seen in experimental studies could not be confirmed in this prospective study with a follow-up period of 3.3 years.

Although similar results were found when analyses were conducted with and without cases diagnosed during the first year of follow-up, a longer follow-up time is needed to be certain that no changes in dairy product consumption occurred as a result of subclinical disease. Moreover, it remains worthwhile to study gender differences and differences between various sites within the large bowel.

\section{References}

1. Netherlands Cancer Registry. Incidence of cancer in the Netherlands. Second report of the Netherlands Cancer Registry, 1990.

2. National Cancer Institute, National Institutes of Health. Dict. Nutrition, and Cancer Prevention. A guide to food choices. Washington, DC, US Government Printing Office (NIH Publ. No. 87-2878), 1978.

3. Metchnikoff E. The prolongation of life. Optimistic studies. G.P. Putman and Sons, New York 1908.

4. Goldin BR and Gorbach SL. The effect of milk and lactobacillus feeding on human intestinal bacterial enzyme activity. Am J Clin Nutr 1984;39:756-761.

5. Marteau P, Pochart P, Flourié B, et al. Effects of chronic ingestion of a fermented dairy product containing lactobacillus acidophilus and bifidobacterium bifidum on metabolic activities of the colonic flora in humans. Am J Clin Nutr 1990;52:685-688.

6. De Simone $C$, Bianchi Salvadori B, Negri R, Ferrazzi M, Baldinelli L, Vesely R. The adjuvant effect of yogurt on production of gamma-interferon by con A-stimulated human peripheral blood lymphocytes. Nutr Rep Int 1986:33:419-433.

7. Perdigon G, Nader de Macias ME, Alvares S, et al. Fiffect of a mixture of lactobacillus casei and lactobacillus acidophilus administered orally on the immune system in mice. J Food Protect 1986:49:986-989.

8. Newmark HL, Wargovich MJ, Bruce WR. Colon cancer and dietary fat, phosphate, and calcium: a hypothesis. J Natl Cancer Inst 1984;72:1323-1325. 
9. van der Meer R, Termont DSML, De Vries HT. Differential effects of calcium ions and calcium phosphate on cytotoxicity of bile acids. Am J Physiol 1991;260:G142-G147.

10. Lipkin $M$ and Newmark $H$. Effect of added dietary calcium on colonic epithelial-cell proliferation in subjects of high risk for familial colonic cancer. $N$ Engl J Med 1985;313:1381-1384.

11. Slattery ML, Sorenson AW, Ford MH. Dietary calcium intake as a mitigating factor in colon cancer. Am J Epidemiol 1988;128:504-514.

12. Kune S, Kune GA, Watson IF. Case-control study of dietary etiological factors: The Melbourne colorectal cancer study. Nutr Cancer 1987;9:21-42.

13. Garland CF, Shekelle RB, Barrett-Connor E, Criqui MH, Rossof AH, Paul O. Dietary calcium and vitamin D and risk of colorectal cancer: a 19-year prospective study in men. Lancet $1985 ; 1: 307-309$.

14. Macquart-Moulin G, Riboli E, Comée J, Charnay B, Berthezène P, Day N. Case-control study on colorectal cancer and dict in Marseilles. Int J Cancer 1986;38:183-191.

15. Rosen M, Nyström L, Wall S. Diet and cancer mortality in the counties of Sweden. Am J Epidemiol 1988;127:42-49.

16. Young TB and Wolf DA. Case-control study of proximal and distal colon cancer and diet in Wisconsin. Int J Cancer 1988;42:167-175.

17. Phillips RL and Snowdon DA. Dietary relationships with fatal colorectal cancer among Seventh-day Adventists. J Natl Cancer Inst 1985;74:307-317.

18. Negri E, La Vecchia C, D'Avanzo B, Franceschi S. Calcium, dairy products and colorectal cancer. Nutr Cancer 1990;13:255-262.

19. Stemmermann GN, Nomura A, Chyou PH. The influence of dairy and nondairy calcium on subsite large bowel cancer risk. Dis Colon Rectum 1990;33:190-194.

20. Peters RK, Pike MC, Garabrant D, Mack TM. Diet and colon cancer in Los Angeles County, California. Cancer Causes Control 1992;3:457-473.

21. Steinmetz KA and Potter JD. Food group consumption and colon cancer in the Adelaide case-control study. II. Meat, poultry, seafood, dairy foods and eggs. Int J Cancer 1993;53:720-727.

22. Bostick RM, Potter JD, Sellers TA, McKenzie DR, Kushi LH, Folsom AR. Relation of calcium, vitamin $\mathrm{D}$, and dairy food intake to incidence of colon cancer among older women. The Iowa Women's Health Study. Am J Epidemiol 1993:137:1302-1317.

23. Kampman E, Giovannucci E, van 't Veer P, et al. Calcium, vitamin D, dairy foods and the occurrence of colorectal adenomas among men and women in two prospective studies. Am J Epidemiol 1994;139:16-29.

24. Consumption statistics for milk and milk products: 1988 IDF-Bulletin 246, 1990.

25. van 't Veer P, Dekker JM, Lamers JWJ, et al. Consumption of fermented milk products and breast cancer: a case-control study in the Netherlands. Cancer Res 1989;49:4020-4023.

26. Bueno de Mesquita HB, Maisonneuve P, Runia S, Moerman CJ. Intake of foods and nutrients and cancer of the exocrine pancreas: a population-based case-control study in the Netherlands. Int J Cancer 1990;48:540-549.

27. van den Brandt PA, Goldbohm RA, van 't Veer P, et al. A large-scale prospective cohort study on diet and cancer in the Netherlands. J Clin Epidemiol 1990;43:285-295.

28. van den Brandt PA, Schouten LJ, Goldbohm RA, et al. Development of a record linkage protocol for use in the Dutch Cancer Registry for Epidemiological Research. Int J Epidemiol 1990; 19:553-557.

29. van den Brandt PA, van 't Veer P. Goldbohm RA, et al. A prospective cohort study on dietary fat and the risk of postmenopausal breast cancer. Cancer Res 1993:53:75-82.

30. Goldbohm RA. van den Brandt PA, Brants HAM, et al. Validation of a dictary questionnaire used in a large-scale prospective cohort study on diet and cancer. Eur $\mathrm{J}$ Clin Nutr 1994;48:253-265.

31. Willett WC. Nutritional Epidemiology. New York: Oxford University Press, 1990.

32. Nevo tabel. Dutch food composition table 1986-87. The Haque, Netherlands: Voorlichtingsbureau voor de Voeding, 1986. 
33. Willett WC and Stampfer MJ. Total energy intake: implications for epidemiological analyses. Am J Epidemiol 1986;124:17-27.

34. Self SG, Prentice RL. Asymptomatic distribution theory and efficiency results for case-cohort studies. Ann Stat 1988;16:64-81.

35. Goldbohm RA, van den Brandt PA, van 't Veer P, et al. Cholecystectomy and colorectal cancer: evidence from a cohort study on diet and cancer. Int J Cancer 1993;53:735-739.

36. Goldbohm RA, van den Brandt PA, van 't Veer P, et al. A prospective cohort study on the relation between meat consumption and the risk of colon cancer. Cancer Res 1994;54:718723.

37. Goldbohm RA, van den Brandt PA, van 't Veer P, et al. Prospective study on alcohol consumption and the risk of cancer of the colon and rectum in the Netherlands. Cancer Causes Control 1994;5:95-104.

38. Rambaud JC, Bouhnik Y, Marteau P, Pochart P. Manipulation of the human gut microflora. Proc Nutr Society 1993;52:357-366.

39. Wu AH, Paganini-Hill A, Ross RK. Henderson BE. Alcohol, physical activity and other risk factors for colorectal cancer: a prospective study. Brit J Cancer 1987;55:687-694. 


\section{Chapter 9}

General Discussion 


\section{Contents}

\section{Integration of results and epidemiological considerations}

Integration of results

Epidemiological considerations

End-points

Assessment of exposure

Variation of exposure and biological relevance

Effect modification

Power consideration

\section{Integration with the literature}

Fermented dairy products

Analytical epidemiological studies

Experimental studies

\section{Calcium}

Analytical epidemiological studies

Human Experimental studies

\section{Concluding remarks}




\section{Integration of results and epidemiological considerations}

\section{Integration of results}

In this thesis the results of four epidemiological studies are described in which the associations between fermented dairy products, calcium and colorectal adenomas or colorectal cancer were examined. The main results and characteristics of these studies are summarized in Figure 9.1 and Table 9.1 respectively.

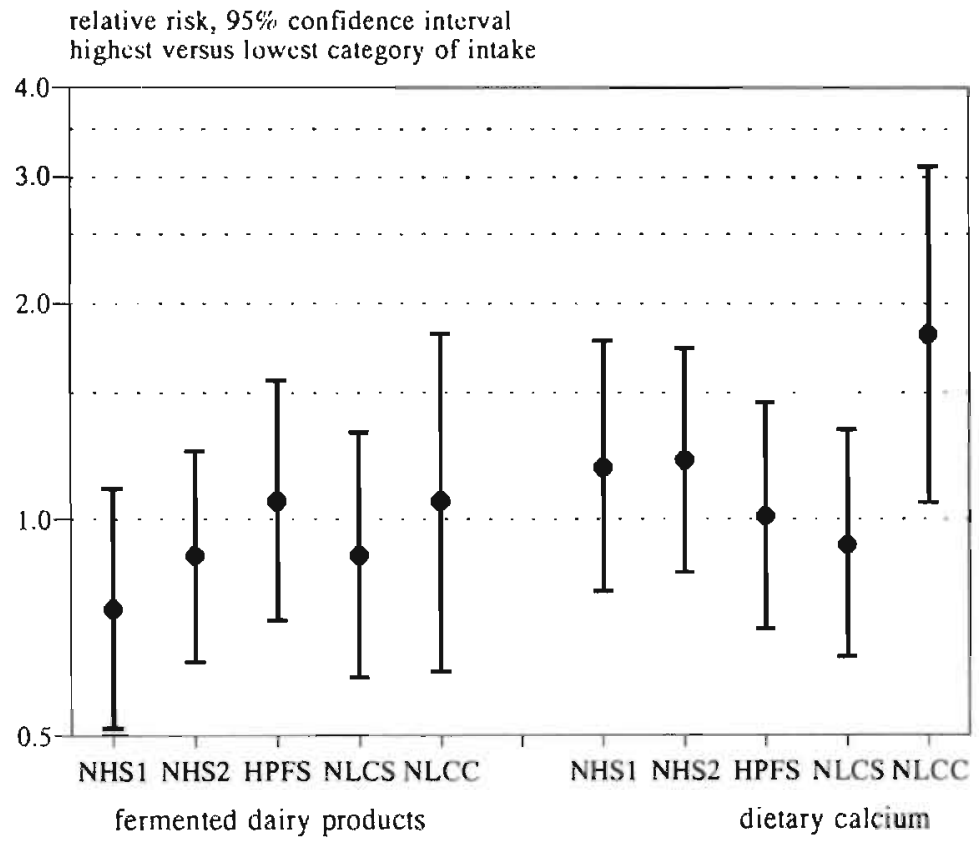

Figure 9.1 Fermented dairy products, calcium and colorectal cancer risk in the four epidemiological studies described in this thesis (NHS1 $=$ Nurses' Health Study 1984-1988: NHS2 = Nurses' Health Study 1980-1988 and Health Professionals Follow-up Study; NLCS = Netherlands Cohort Study; NLCC $=$ Netherlands Case('ontrol study).

For fermented dairy products non-significant inverse associations were observed in the two follow-up periods of the Nurses' Health Study (Chapter 3) for colorectal adenomas and in the Netherlands Cohort Study (Chapter 8) for colorectal cancer, while in the Health Professionals Follow-up Study (Chapter 3) and the Netherlands Case-Control Study (NLCC) non-significant positive associations were observed (Figure 9.1). Dietary calcium was non-significantly inversely related to risk in the Netherlands Cohort Study, while no association was found in the Health Professionals Follow-up Study, a non-significant positive association was observed 
in both follow-up periods of the Nurses' Health Study and a significant increased risk with increasing calcium intake was found in the Netherlands Case-Control Study.

The overall inverse variance weighted estimate of relative risk in these four studies, excluding Nurses' Health Study 2, was $0.91(95 \% \mathrm{CI}=0.74-1.12)$ for the highest vs. the lowest category of fermented dairy product consumption and 1.10 $(95 \% \mathrm{Cl}=0.90-1.35)$ for the highest vs. lowest category of dietary calcium intake. Overall, the suggested protective effect of fermented dairy products and dietary calcium on colorectal adenomas or cancer risk is not supported by the results of these studies.

These null findings might reflect the underlying association, but might also result from a failure to observe a truly existing inverse association. Such a failure might be attributed to the end-point under study, the methodology of exposure assessment, the variation of exposure in the study population and the bioiogicai relevance, confounding or effect modification or a lack of statistical power. ${ }^{1}$ The purpose of this chapter is to discuss these possible explanations for our null findings (see 'Epidemiological considerations'). In addition, the external validity of these studies is evaluated by comparing our findings with the results of other analytical epidemiologic studies and human experimental research (see 'Integration with the literature').

The studies described in this thesis represent three different end-points (distal adenomas, colon and rectal cancer), three different epidemiological study designs (cohort, case-subcohort, case-control), two different methods of exposure assessment (semi-quantitative food frequency and dietary history) and, since these studies were conducted in different populations (US and the Netherlands), different ranges of fermented dairy product intake (Table 9.1). The studies can be compared to a reasonable degree with respect to definition of exposure and adjustment for potential confounding variables. The advantages and disadvantages of these studies are described in more detail in the corresponding chapters (Chapter 3 to 8).

\section{Epidemiological considerations}

\section{End-points}

As discussed in Chapter 2, colorectal carcinogenesis is a process of several stages in which adenomatous polyp formation precedes the formation of the malignant tumor. The mechanisms by which fermented dairy products and calcium might reduce colorectal cancer risk could involve earlier stages as well as later stages in the polyp-cancer sequence and may differentially affect the various sites of the colorectal tract (Chapter 2). 
Adenomatous polyps can serve as an intermediate end-point for the sludy of determinants of colorectal cancer, which shortens the period hetween dietary assessment and the onset of the disease. If diet affects polyp formation, stronger associations with fermented dairy products and calcium might be found when studying these precursor lesions.

Table 9.1 Characteristics of the four studies described in this thesis.

\begin{tabular}{|c|c|c|c|c|c|}
\hline & $\begin{array}{l}\text { Nurses' } \\
\text { Health Study } \\
1\end{array}$ & $\begin{array}{l}\text { Nurses' } \\
\text { Health Study } \\
2\end{array}$ & $\begin{array}{l}\text { Health } \\
\text { Professionals } \\
\text { Follow-up } \\
\text { Study }\end{array}$ & $\begin{array}{l}\text { Netherlands } \\
\text { Cohort Study }\end{array}$ & $\begin{array}{l}\text { Netherlands } \\
\text { Case-Control } \\
\text { Study }\end{array}$ \\
\hline Type of study & cohort & cohort & cohort & cohort & case-control \\
\hline Population & $\begin{array}{l}\text { US, } \\
\text { endoscopied } \\
\text { nurses } \\
\text { (women) }\end{array}$ & $\begin{array}{l}\text { US. } \\
\text { endoscopied } \\
\text { nurses } \\
\text { (women) }\end{array}$ & $\begin{array}{l}\text { US, } \\
\text { endoscopied } \\
\text { health } \\
\text { professionals } \\
\text { (men) }\end{array}$ & $\begin{array}{l}\text { Netherlands, } \\
\text { gencral } \\
\text { population }\end{array}$ & $\begin{array}{l}\text { Central and East } \\
\text { Netherlands, } \\
\text { general } \\
\text { population }\end{array}$ \\
\hline End-point & $\begin{array}{l}\text { distal colon, } \\
\text { rectum, } \\
\text { adenoma }\end{array}$ & $\begin{array}{l}\text { distal colon, } \\
\text { rectum, } \\
\text { adenoma }\end{array}$ & $\begin{array}{l}\text { distal colon, } \\
\text { rectum, } \\
\text { adenoma }\end{array}$ & $\begin{array}{l}\text { colon, rectum, } \\
\text { carcinoma }\end{array}$ & colon carcinoma \\
\hline $\begin{array}{l}\text { Years of } \\
\text { follow-up }\end{array}$ & 4 & 8 & 4 & 3.3 & - \\
\hline $\begin{array}{l}\text { Number of cases/ } \\
\text { controls or } \\
\text { cohort }\end{array}$ & $283 / 6,988$ & $350 / 8,575$ & $331 / 9,159$ & $326 / 3,083$ & $232 / 259$ \\
\hline Dietary method' & $\begin{array}{l}\text { sqffq } \\
\mathrm{i}=121\end{array}$ & $\begin{array}{l}\text { sqffq } \\
i=61\end{array}$ & $\begin{array}{l}\text { sqffq } \\
i=131\end{array}$ & $\begin{array}{l}\text { sqffq } \\
i=150\end{array}$ & $\begin{array}{l}\text { dietary history } \\
\mathrm{i}=289\end{array}$ \\
\hline $\begin{array}{l}\text { Median (per day) } \\
\text { highest quintile } \\
\text { or quartile of } \\
\text { intake }\end{array}$ & $\begin{array}{l}\text { ferm.dairy } \\
129 \mathrm{~g} \\
\text { calcium: } \\
1.550 \mathrm{mg}\end{array}$ & $\begin{array}{l}\text { ferm.dairy: } \\
1.34 \mathrm{~g} \\
\text { calcium: } \\
1,160 \mathrm{mg}\end{array}$ & $\begin{array}{l}\text { ferm.dairy }{ }^{3} \text { : } \\
111 \mathrm{~g} \\
\text { calcium: } \\
1,500 \mathrm{mg}\end{array}$ & $\begin{array}{l}\text { ferm.dairy': } \\
207 \mathrm{~g} \\
\text { calcium: } \\
1,288 \mathrm{mg}\end{array}$ & $\begin{array}{l}\text { ferm.dairy }{ }^{5}: \\
335 \mathrm{~g} \\
\text { calcium: } \\
1,712 \mathrm{mg}\end{array}$ \\
\hline Adjusted for & $\begin{array}{l}\text { age, energy, } \\
\text { bmi,alcohol, } \\
\text { folate, sat.fat, } \\
\text { fiber, } \\
\text { fam.history } \\
\text { endoscopies }\end{array}$ & see NHS1 & see NHS 1 & $\begin{array}{l}\text { age, gender, fat } \\
\text { energy, fiber, } \\
\text { bmi, fam.history } \\
\text { cholecystectomy }\end{array}$ & $\begin{array}{l}\text { age, gender, } \\
\text { energy, fat, } \\
\text { fiber, } \\
\text { fam.history, } \\
\text { cholecystectomy, } \\
\text { alcohol, vit.C }\end{array}$ \\
\hline
\end{tabular}

sqffq, semi-quantitative food frequency questionnaire.

among controls or (sub)cohort.

yogurt, sour cream, cream cheese, cottage cheese, hard cheese.

yogurt, buttermilk.

5 yogurt, buttermilk, sour cream, curds, kefir, other fermented milk drinks. 
Since we assessed the association between these exposures and the risk of both adenomas as weli as cancer, it is unlikely that an important effect was missed just because of an irrelevant time window in colorectal cancer aetiology. Despite these biological and methodological considerations, no differences in associations with fermented dairy products and calcium were observed for colorectal adenomas and colorectal cancer: for both end-points no important associations were found.

Based on experimental and epidemiological studies suggesting partially different aetiologies for cancer of the colon and rectum, we examined the association with risk for these different subsites separately. Slight differences were observed between colon and rectum cancer in the Netherlands Cohort Study: fermented dairy product consumption was more strongly associated with colon cancer risk, while the intake of calcium from unfermented dairy products was inversely associated with rectal cancer.

Canaer of the proximal and distal sites of the colon mignt be explained by different aetiological factors as well. However, since sigmoidoscopy or endoscopy usually do not reach the proximal site of the colon, this site was not taken into account in studying adenoma risk. Because of power considerations, we did also not explore differences between subsites in the studies on colon cancer.

Thus, the null findings of these studies are not likely to be explained by the choice of the end-point under study. However, the potential differences between colon and rectal cancer, and among different subsites within the colon, need further study. A longer duration of follow-up of the Netherlands Cohort Study will provide opportunities to explore these differences in more detail and to study different subsites within the colon. These additional analyses will be conducted after 5 years of follow-up supported by a grant from the Netherlands Digestive Diseases Foundation.

\section{Assessment of exposure}

The main hypothesis in this thesis was studied in three prospective studies and one retrospective study. Prospective studies are less prone to potential sources of methodological bias in exposure assessment, such as recall and selection bias, associated with retrospective case-control investigations. Because in prospective studies exposure information is collected before diagnosis, illness is not very likely to affect recall of previous habits. In Chapter 5 it is discussed that recall bias might be especially important in a case-control study when cases, as a result of their disease, report their usual intake before complaints started or diagnosis occurred differently from the control group. This problem is becoming increasingly relevant because of the widespread publicity about diet and cancer. However, since dairy products have a good image in the Netherlands, it is thought to be unlikely that 
cases, whether or not intentionally, have overestimated their calcium intake to 'explain' their illness. Furthermore, dietary patterns might have been adapted to gastro-intestinal distress or food aversions associated with therapy. Since current dietary patterns influence the recall of past diet, ${ }^{\prime}$ such changes might bias the results importantly. In our case-control study, none of those who replied to suffer from gastro-intestinal distress reported to have changed their consumption of dairy products (Chapter 2).

The second cause of a lack of internal consistency in a case-control study could be biased sampling of cases and controls, especially when participation rates are low. In our case-control study $60 \%$ of the invited cases $57 \%$ of the controls were willing to be interviewed. In Chapter 4 it is argued that the possible selection of cases and controls due to non-response will strengthen an inverse association. However, those who completed the non-response questionnaire may not be representative of the total of non-responders (Chapter 4). The fact that more cases with a relatively good prognosis have been included in the case-control study is not likely to have influenced the results considerably, since consumption of fermented dairy products and intake of calcium were not related to Dukes' status (Chapters 4 and 5). Furthermore, recruitment of controls by the general practitioner of the cases made the control group more comparable to the general population with respect to socio-economic level than a control group recruited via municipal registries. This might explain differences with previous Dutch case-control studies on breast and pancreas cancers respectively ${ }^{2,3}$ (Chapters 4 and 5).

A methodological bias which might be important both in retrospective and in prospective designs, is that the method of dietary assessment is not sufficiently precise to measure differences that truly exist. ${ }^{1}$ Evaluations of the validity and reproducibility of the semi-quantitative food frequency questionnaires used in the American and the Dutch prospective studies indicated that these questionnaires provided useful information about the consumption of dairy products and calcium (Chapters 3 and 8). The dietary history questionnaire in the case-control study was an extended version of a previously used validated questionnaire (Chapter 4). The median intake of calcium among controls in the case-control study was higher than in the Netherlands Cohort Study and higher than the estimated mean intake in the general Dutch population as assessed by a two-day dietary record. ${ }^{4}$ This might be a consequence of the extensive number of questions addressing dairy products. In the American studies the questionnaires used in the four-year follow-up included 11 dairy items, in the Netherlands Cohort Study 9 dairy items were asked for, while in the case-control study the consumption of all common dairy items used during different meals was assessed with a maximum of about 25 products. Furthermore, the questionnaire used in the case-control study was a fully quantitative 
questionnaire. Sizes of major cups and utensils were measured. The questionnaire used in the case-control study was interview-based and not self-administered. This is believed to contribute to a higher degree of internal consistency in the reported food pattern, resulting in more precise estimates of consumption. ${ }^{5}$

With respect to the time window of dietary assessment, it is clear that the American studies covered a period preceding tumor formation. Nevertheless, when the onset of the disease occurred during childhood, we may have missed a truly existing association. It seems however unrealistic to assume that valid information could have been gathered since studies conducted to date suggest that diet may be recalled with acceptable levels of misclassification up to approximately 10 years.' Moreover, the fact that colorectal cancer rates rise consistently with migration and westernization" suggest that dietary factors might be especially important in adult life.

Thus, although some degree of recall bias and selection bias can never be complctcly ruled out in a retrospective study, the errors associated with assessment of fermented dairy product consumption and calcium intake in these studies are not likely to be influenced by methodological biases.

\section{Variation of exposure and biological relevance}

To observe a possible statistically significant inverse association between fermented dairy products, calcium and colorectal cancer, sufficient variation in consumption levels for fermented dairy products and calcium in the study population is required. Moreover, it must be considered whether the absolute level of intake is of biological relevance and whether negative confounding exists.

The consumption of fermented milk, such as yogurt and buttermilk, is strongly related to taste: the fact that the sour taste is liked or disliked contributes to variation in consumption level. Since fermented dairy products are integrated in the traditional Dutch food pattern and the per capita consumption of these products is much higheer than in the US (Chapter 2), it might be worth-while to study this subject in the Netherlands. Although consumption of fermented dairy products indeed differed between the Dutch and the American studies (Table 9.1), the intake of calcium did not differ appreciably between populations in the prospective studies (Table 9.1). However, despite the higher and more heterogeneous consumption of fermented dairy products in the Netherlands, the estimates of the four studies did not differ appreciably.

It is questionable whether the consumption of fermented dairy products or the intake of calcium was high enough to exert a biological effect. Our ecologic study (Chapter 2, Figure 2.2) suggested that the range of consumption of fermented milk in the Netherlands Case-Control Study (about $330 \mathrm{~g} /$ day) is sufficiently large to be 
able to observe a relative risk less than 0.5. Morcover, the level of consumption of fermented dairy products in the Dutch studies was comparable to that in a previous study on breast cancer in which a protective effect was observed. However, based on the results of experimental studies, it may be inferred that still a higher and more frequent consumption is necessary to influence the colonic flora (see 'Experimental studies"). With respect to dietary calcium the range in intake in our studies should have been high enough to show a decrease in risk as calculated by Garland's' and Newmark' $\mathrm{s}^{8}$ groups. They estimated an intake of $1,200-1,500 \mathrm{mg}$ calcium per day to be sufficient to neutralize bile acids and free fatty acids in the colonic lumen with an intake of about $150 \mathrm{~g}$ fat and $1,500 \mathrm{mg}$ phosphate per day. The mean intake of fat in our studies was about 80 to $90 \mathrm{~g}$ per day, whereas the mean intakes of phosphate and calcium ranged from 1,200 to $1,700 \mathrm{mg}$ in the highest categories. This implies that a substantial proportion of participants in our studies should have been consuming an adequate amount of calcium to experience the biological effects. On the other hand, if calcium influences cell proliferation directly, which is the second hypothesized mechanism as described in Chapter 2, the intracellular concentration might be more important than the intraluminal calcium content. In this respect, vitamin D status might be of major importance. However, in the American cohorts, vitamin D intake did not influence the results on colorectal polyps (Chapter 3; and see 'Effect modification'). In the Dutch studies vitamin D exposure was not assessed (Chapters 5 and 8).

The biological relevance might also depend on the specific strains of bacteria used for the fermentation process. The bacterial strains used to culture milk might differ among countries, states and products. In the Netherlands, Luctobacillus bulgaricus, Streptococcus thermophilus, $S$. lactis and S. tremor are mainly used to produce yogurt and buttermilk. These strains are used in some parts of the US as well, but in other parts Lactobacillus acidophilus is more frequently used for fermentation. Since several strains might not survive the gastro-intestinal tract and possibly only viable bacteria exert an effect on the bowel flora (see 'Experimental studies'), the differences in findings among epidemiological studies might be explained by differences in fermented dairy products studied. However, in a Dutch case-control study on breast cancer, an inverse association was observed for yogurt, buttermilk and cheese, whereas cheese mainly contains unviable bacteria. In the four studies no differences among the different fermented dairy products were found.

Considering the population-specific confounding variables, it was expected that, since the consumption of fermented milk is rare sparse in the US, the consumption of these products might be related to other health conscious habits. However, in the two Dutch studies the use of fermented dairy products was also clearly related to 
health consciousness (e.g. less smoking, less alcohol use, more supplement use, a higher consumption of vegetables). Adjustment for these potential confounding variables did not influence the estimates importantly, however.

In conclusion, variation in intake, absolute consumption levels for fermented dairy products and calcium or confounding are not likely to explain the null findings of our studies. However, these results do not exclude the possibility that inverse associations might still be found with higher doses of dairy products, or with products cultured with other bacterial strains.

\section{Effect modification}

Interaction with other dietary variables might have influenced the results. As described in Chapter 2, especially a high dietary phosphate/calcium ratio or the vitamin D status might modify the associations between calcium and colorectal cancer risk. Furthermore, if calcium exerts an effect on colorectal carcinogenesis by binding bile acids and free fatty acids, whose concentrations in the colonic lumen raise with higher saturated fat intake, the observed association may depend on the fat content of the diet. Finally, dietary fiber might modify the effect by binding calcium. The possible effect modifications were studied in the American studies by assessing the association with calcium at different levels of phosphate, vitamin D, saturated fat and dietary fiber intake. It appeared that the associations between calcium and colorectal polyp risk did not differ at different levels of intake of these dietary variables. Moreover, a high phosphorus intake relative to the intake of calcium was evaluated in all four studies. The ratio was not associated with adenoma or carcinoma risk.

Apart from mechanistic interactions, sex and/or age may be potential effect modifiers. Incidence rates differ between men and women uver categories of age (Chapters 2 and 6). The four studies differ in gender and age distribution: at baseline the Nurses' Health Study included women only, who were mainly premenopausal, while the Health Professionals Follow-up Study included only men, aged between 40 and 75 . The two Dutch studies both included men and women: the Netherlands Cohort Study included middle-aged men and women, while in the Netherlands Case-Control Study men and women younger than 76 years at diagnosis were included (mean age about 61). Differences were observed between genders: consumption of yogurt and buttermilk was significantly higher among women. Moreover, the association between consumption of fermented dairy products and colorectal adenoma or cancer risk differed between genders: among women (non-significant) inverse associations were found, while for men these associations tended to be positive. For dietary calcium differences between genders were not consistently found (Figure 9.2). 
In the Netherlands Case-Control Study a significant difference between men and women was observed for fermented dairy products. Additionally, gender interactions were observed for fruit and meat consumption (Chapter 7) and different associations with parity and age at first child birth were found for men and women (Chapter 6).

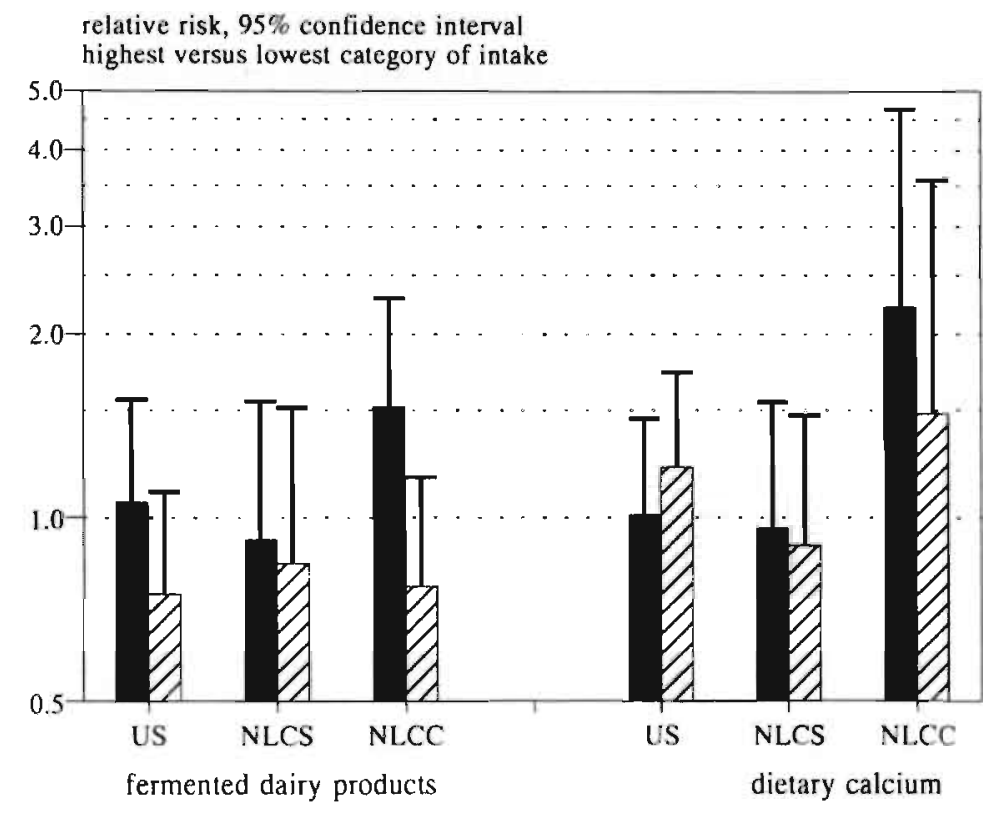

$\square$ men $\triangle$ women

Figure 9.2 Gender-specific associations between colorectal cancer and fermented dairy products and dietary calcium (US = Nurses' Health Study 1 and Health Professionals Follow-up Study; NLCS = Netherlands Cohort Study; NLCC $=$ Netherlands Case-Control study).

Differences in the strength of associations between men and women might be attributed to differences in internal validity of the studies for both sexes or by actual biological differences. Considering the internal validity of the studies, men might report their diet less accurately than women, which might attenuate the relative risks. However, in a review of dietary recall methods by Friedenreich et al., it was concluded that men and women recall their previous diet with a similar accuracy." Furthermore, in the Netherlands Case-Control study this difference in reporting should be minimal since women, who normally cook the main meal in this older age group, were present during their husbands' interview. Moreover, the Dutch National Food Consumption Survey data support the finding that the consumption of fermented dairy products is higher among women. ${ }^{9}$

Finally, biological explanations might be proposed as well. As described in 
Chapters 2 and 6 , it has been suggested that the causes of colorectal cancer differ between the genders. Therefore, it might also be expected that the most effective agents for reducing the risk would also differ between the genders. Since colon physiology differs between genders (Chapter 2), the survival and colonization of lactobacilli strains in the gastro-intestinal tract might differ. If hormonal factors would be important in the adherence of lactobacilli and in calcium metabolism, differences might be expected between pre- and postmenopausal women. However, the association with fermented dairy products did not differ between the Nurses' Health Study and the Netherlands Cohort Study.

Overall, differences among men and women in the strength of associations with fermented milk intake should be explored further in epidemiological as well as experimental studies.

\section{Power considerations}

An association may be missed because of low statistical power due to an inadequate size of the study population. A low statistical power may have been important in the smallest of the four studies with, as a consequence, the largest confidence intervals: the Netherlands Case-Control Study. A priori power calculations are presented for this study in Chapter 4 . In the final analyses of the case-control study, 232 cases and 259 controls were included (Chapters 5-7). According to our calculations, with a variation in intake between the highest and lowest quartile of about $800 \mathrm{mg}$ calcium per day, an odds ratio of 0.5 could have been detected with a power of approximately $80 \%(\alpha=0.05)$.

The number of cases in the case-control study was almost similar to the number of cases in the prospective studies, while the 'sample' from the source population was 10 to 30 times smaller. Nevertheless, the standard errors of the prospective studies are only half of those in the case-control study. This illustrates the efficiency of a case-control design.

Considering the findings of the prospective studies, it does not seem likely that the failure to observe an inverse association between calcium and colon cancer risk is a result of inadequate statistical power.

\section{Integration with the literature}

To study the external validity, the results of these four studies are compared with the epidemiolngical literature reviewed in Chapter 2 according to the aspects discussed above. In general, it can be stated that, apart from our own studies, hardly 
any of the epidemiological studies conducted have focused specifically on the consumption of milk products or calcium intake. Therefore, these studies may not have fully addressed all the confounding and interaction issues. Moreover, the possibility of reporting and publication biases should be taken in mind. Additionally, the epidemiological findings are compared with the experimental evidence as summarized in Chapter 2.

\section{Fermented dairy products}

\section{Analytical epidemiological studies}

None of the case-control studies on colorectal polyps and none of the prospective studies on colorectal cancer reported to date have addressed the consumption of fermented milk. Only three case-control studies have addressed the consumption of yogurt or buttermilk: two studies on colon cancer conducted in the US by Young and Wolf ${ }^{10}$ and Peters et al.," ${ }^{11}$ and one Japanese study on colon and rectal cancer by Tajima and Tominaga. ${ }^{12}$ In the American studies, a significant inverse association was observed, while the Japanese study found a significant positive association with yogurt consumption for colon as well as rectal cancer. The differences observed between our findings and these studies may be related to differences in source populations, methods of dietary assessment and dietary methodology used.

The study by Peters at al., which is the largest of the case-control studies on colon cancer to date (746 cases, 746 controls), was conducted in Los Angeles county, while Young and Wolf conducted their study in Wisconsin. The difference with our findings might be explained by a difference in bacterial strains used to culture milk across the areas covered by the studies. Analyses in the Nurses' Health Study and the Health Professionals Follow-up Study, covering 11 different US states, were not stratified by state.

The dietary methodology used in the study by Peters et al. is a mixture of the methodologies used in our American studies and our Dutch case-control study: the questionnaire Peters et al. used was an interview-based, slightly expanded version of the semi-quantitative questionnaire used in the Nurses' Health Study and the Health Professionals Follow-up Study (Chapter 3), quantifying portion sizes. In the other case-control study, by Young and Wolf, dietary habits during different age stages were asked for. The inverse association was only observed among those over 34 $(\mathrm{OR}=0.7,95 \% \mathrm{CI}=0.4-1.0)$ and not at younger ages in which odds ratios of 0.9 (between 18 and 35 years) and 1.0 (under age 18) were observed, ${ }^{10}$ which might point to chance, a late stage effect or a hormonal effect. With respect to the third study, conducted in Japan, it is not possible to compare our findings, since their methodology is described only briefly and the source population is very different. 
Our findings for cheesc consumption are not in line with one of the two prospective studies and three of the six case-control studies addressing hard cheese consumption in which positive associations for colorectal cancer were found (Chapter 2). Significant positive associations were observed for rectal cancer only. In most of the studies addressing cheese consumption, the analyses were not adjusted for fat intake. Our null findings for cheese are especially interesting since cheese is a high-fat food item and an increased risk with dietary fat was observed in the Nurses' Health Study, the Health Professionals Follow-up Study and the Netherlands Case-Control Study.

The prospective study by Phillips et al. ${ }^{13}$ found a significant positive association with cheese consumption for men, while a non-significant inverse association was found for women. Although this might support a hormonal effect of lactobacilli, it might also point to other habits related to cheese intake. Since none of the other studies on fermented dairy products report results of analyses stratified by gender firm conclusion cannot be drawn.

The results of the Netherlands Cohort Study and the Netherlands Case-Control Study are not in line with the results of previous case-control studies on breast cancer $^{2}$ and pancreatic cancer conducted in the Netherlands. ${ }^{3}$ Both studies observed an inverse association with consumption of fermented dairy products. Although the aetiology of colon cancer differs from that of breast cancer and pancreatic cancer, the inverse associations reported from these studies might be explained by the choice of the control group. Consumption of fermented dairy products is significantly higher in those with a higher socio-economic status. If the populationbased control groups used in those studies included a higher proportion of more health-conscious, more educated and well-to-do persons, these studies could erroneously observe an inverse association with fermented dairy products. As described in Chapter 4 , the socio-economic status distribution of the control group used in our case-control study was comparable to that of the general Dutch population. The additional control group we recruited via municipal registries, like in the other case-control studies, indeed included more persons with a higher socioeconomic status.

Overall, the epidemiological evidence on fermented dairy products is too sparse to allow firm conclusions to be drawn. The available evidence, however, does not provide strong evidence for a clear preventive potential.

\section{Experimental studies}

Like epidemiological studies, experimental data on fermented dairy products or lactic acid bacteria are sparse and preliminary. As reviewed in Chapter 2, experimental studies on lactic acid bacteria focus especially on (1) modulations of 
the colonic flora, (2) enhancement of the immune response and (3) mutagen absorption.

Several investigators explored the first hypothesis and endorse a decline in activity of several faecal enzymes. However, the role of these enzymes in the aetiology of colorectal cancer has not been substantiated, the mechanisms by which lactic cultures decrease enzyme activity is not known and a reliable measurement of faecal enzymes remains difficult. ${ }^{14}$ It is not clear whether only strains that are resistant to gastric acidic conditions and remain viable in the colon exert an effect. $^{15,16}$ Most experimental studies used specific strains that are not normally present in commercially available fermented dairy products, which might explain why their results differ from our epidemiological studies. Furthermore, it is still questionable whether a daily dairy dose of lactic acid bacteria is large enough to influence colonic metabolism, since the number of bacteria in the colon is much larger. There is no evidence that lactobacilli can establish themselves in the intestinal tract and it could be that fermented milk needs to be ingested continuously, or at least regularly, to maintain a sufficient number of lactobacilli in the intestine.

Research on the other two hypothesized modes of action of lactic acid cultures is still very preliminary. It is not clear whether ingestion of large numbers of lactobacilli stimulates the human immune system more than the normal constant stimulus by the gut flora already does. Mutagen absorption studies are mainly in vitro studies whose physiological significance may be limited. There is no evidence for any specificity of lactobacilli in mutagen binding.

Overall, experimental data on commercially available fermented dairy products are limited and too preliminary to provide evidence for a protective effect of fermented dairy products on colorectal cancer risk.

\section{Calcium}

\section{Analytical epidemiological studies}

Two small retrospective studies have addressed the intake of dietary calcium and the occurrence of colorectal polyps (Chapter 2): odds ratios of $0.9^{17}$ and $1.2^{18}$ were reported. These results are in line with the findings in the Health Professionals Follow-up Study and the Nurses' Health Study respectively (Chapter 3).

Results on dietary calcium intake and colorectal cancer in the Netherlands Cohort Study are comparable with the results of 4 of the 6 prospective studies on colorectal cancer addressing dietary calcium intake (Chapter 2). Five of these studies were conducted in the US. Garland et al., ${ }^{19}$ whose study is the most cited study on calcium and colorectal cancer risk, reported a significant inverse association with 
dietary calcium ( $R R=0.32$ for highest vs. lowest intake). This study is the smallest prospective study $(n=49$ ), but used a fairly reliable instrument for the dietary assessment: two 28-day dietary histories one year apart. The study was restricted to men. A prospective study based on 24-hour recalls among Hawaiian Japanese men, with a relatively low intake of calcium and fat, found a non-significant inverse association for overall colon cancer risk, but a significant inverse association for cancer of the sigmoid. A previous publication on the same study did not report important associations (Chapter 2). In the two other well-known prospective studies, the Nurses' Health Study and the Iowa Women's Health Study, which included only women and assessed dietary habits through a semi-quantitative food-frequency questionnaire, no associations with dietary calcium were observed. ${ }^{20,21}$ The results of the 6-year follow-up of the Health Professionals Follow-up Study on colorectal cancer do not support a protective effect of dietary calcium either (E. Giovannucci, personal communication, 1994). ${ }^{22}$

The significant positive association between dietary calcium and colon cancer observed in our case-control study is not supported by previous studies. Three casecontrol studies observed a positive association with dietary calcium, albeit none of these associations were significant (see Chapter 2). Five of the 13 case-control studies published to date report a significant inverse association with colon cancer or rectal cancer for either men or women, while 5 reported non-significant inverse associations. Case-control studies reporting inverse associations did not differ in size, number of cases, end-point, population, age and sex or dietary methodology from those reporting positive associations.

As to calcium from supplements, a significant inverse association was found in the Iowa Women's Health Study. Although supplement use might be a proxy for other healthy habits, this result might also support the notion that dietary intake of calcium is not high enough to exert an effect. However, in the Nurses' Health Study and the Health Professionals Follow-up Study no important association between supplemental calcium and the occurrence of colorectal adenomas was found. In the Netherlands the intake of supplements is too infrequent to get reliable estimates.

In summary, the results of our and other epidemiological studies do not consistently support a substantial protective effect of dietary calcium in the westernized diet.

\section{Human experimental studies}

Like the results from epidemiological studies mentioned above, the results of human experimental studies on calcium are not consistent (Chapter 2). Since 1985, at least 15 clinical trials have been conducted investigating the effect of calcium on reduction of the colurectal epithelial cell proliferation rate. All of these studies were 
small and most of them did not use a double-blind placebo-controlled design. Most studies have examined the overall cell proliferation rate in the rectal mucosa as the study end-point. The conduct of these studies relied on the assumption that reduction of colonic proliferation rate is related to a reduced risk of colorectal cancer (Chapter 2). In about half of these studies a significant decrease in labelling index was actually detected, of which $50 \%$ were conducted by the groups of Lipkin and Wargovich (Chapter 2).

The differences in outcomes between the different trials could not be explained by their design (placebo-controlled or not), the labelling technique used (most studies used tritiated thymidine), duration of supplementation or the type of calcium salt supplemented.

Discrepancies might be related to the number of crypts scored, biopsy procedures used, labelling failure, reader reliability and participant withdrawal as suggested by Bostick and et al. ${ }^{23}$

The dose of calcium used for supplementation was found to be a predictor of the outcome. A placebo-controlled trial by Wargovich et al. showed that an increase in dose resulted in a significantly stronger decrease in labelling index (Chapter 2). The daily dose of calcium used in the studies ranged from 1,000 tot $2,000 \mathrm{mg}$ per day. Besides the dose of supplemented calcium, dietary intake of calcium at baseline and during the intervention is important. Most studies explicitly state that participants were asked not to change their dietary patterns during calcium supplementation. However, only a few studies verified the actual intake before and after supplementation. ${ }^{24-26}$ The same investigators reported on the intake of nutrients other than calcium, which might affect colonic mucosa proliferation as well. ${ }^{24.25}$

In the above studies biopsies were usually taken from the rectum; as this is an invasive procedure, most studies were conducted among patients with a genetically determined increased risk of colon cancer. These persons might have a higher labelling index at baseline than subjects with sporadic colon cancer. The baseline labelling index values reported varied considerably, i.e. from $5 \%^{24}$ to $17 \%^{28}$ (Chapter 2). These large discrepancies may be related to the populations studied or to technical differences and the reproducibility of the methods used. It is not clear whether the degree of hyperproliferation at baseline influences the effects of calcium. ${ }^{28}$

The basic assumption in these studies has been that rectal biopsies reflect hyperproliferation throughout the colon. The only study in which biopsies were taken from the mid-sigmoid, however, observed an increase in labelling index after supplementation. ${ }^{26}$ Coincidentally, the results of this latter Dutch study by Kleibeuker et al. are in line with the positive association observed between calcium and the risk of colon cancer in our Netherlands Case-Control Study. 
The assumption that a reduction of proliferation rate is related to a reduced risk of colorectal cancer has not been established; a reduction of proliferation rate may not be sufficient to reverse the carcinogenic process. ${ }^{27}$

Most published studies have investigated overall cell proliferation. A reduced proliferation rate is not supported by the largest placebo-controlled trial on calcium conducted to date, which included 193 cases with sporadic adenomas, and which has been completed very recently. However, the results do show an effect of calcium on the normalizing downwards shift of the proliferative zone (J.D. Potter, personal communication, 1994) as has also been reported previously by Lipkin et al. in an uncontrolled trial. ${ }^{28}$

The results of of the large trial mentioned above suggest that the mechanism by which calcium reduces colorectal cancer risk might be far more complex than previously proposed by Newmark et al. ${ }^{8}$ who hypothesized that calcium binds toxic fatty acids and bile acids. For instance, in a recent study by Alder et al., faecal pH and deoxycholic acid concentrations tended to increase during calcium supplementation."

However, even if the precise mechanism is still unknown and if cell proliferation is a biomarker for colorectal cancer risk, the current data indicate that a total of at least $2000 \mathrm{mg}$ calcium per day would be necessary to decrease the proliferation of the mucosa importantly. If so, this dose largely exceeds the usual dietary dose. Therefore, the relatively low level of calcium intake in our epidemiological studies can still be compatible with our null findings or with the overall slightly inverse association reported in the literature.

\section{Concluding remarks}

The studies described in this thesis do not substantiate an important preventive potential for fermented dairy products and dietary calcium. However, it is still questionable whether our findings contradict the results of experimental studies. Human experimental studies are usually conducted with fermented dairy products which are commercially not available, while the dose of lactobacilli or calcium salts is much higher than the average intake in the population at large. Placebo-controlled studies with commercially available products and lower doses might help to explain the differences in findings between epidemiolngical and human experimental studies.

Experimental studies exploring different end-points should be conducted. Instead of overall proliferation rate, more emphasis should be placed on the potential effect of calcium to shift the zonc of proliferation from one that includes the entire crypt 
to one that is confined to the lower zone of the crypt. More evidence need to be gathered on whether hyperproliferation is indeed a suitable intermediate stage in colorectal carcinogenesis. Moreover, hyperproliferation is mainly assessed in rectal epithelium, while in the only experimental study focusing on the sigmoid part of the colon, a positive association with calcium was observed. Experimental as well as epidemiological studies should further explore differences in aetiology between colon and rectal cancer and between the different sites within the colon.

Large intervention studies are currently being undertaken in the $\mathrm{US}^{30}$ and Europe $^{31}$ studying the effect of different dietary factors on either the occurrence or the recurrence of polyps. These studies might provide insight into the effect of diet on early events relevant to colorectal carcinogenesis. Fermented dairy products and dietary calcium might be studied in similar designs with an emphasis on different subsites within the large bowel. However, supplemention with large amounts of calcium might not be completely harmless. For instance, Paraskeva argued that caution is necessary with regard to dietary intervention studies. ${ }^{32}$ He indicated that differential sensitivity of normal and malignant tissue to calcium in vitro ${ }^{33}$ raises the possibility that levels of calcium inhibiting the growth of normal epithelium might provide a selective growth advantage of both adenoma and carcinoma cells over normal cells, and thereby promote carcinogenesis in the long run. ${ }^{32}$ Although this hypothesis is not supported by human experimental studies, it might be important to explore this further before large-scale intervention takes place.

Differences between genders in colon cancer risk at specific subsites and the different associations observed for several dietary factors still provide interesting leads for research. Sex differences in colon physiology related to the bacterial flora should be explored more explicitly.

Several lines of inquiry hint at links between epidemiological risk factors and processes on the molecular level. Some of these are described in Chapter 2 of this thesis. Genetic susceptibility to colorectal cancer might be more important than one would expect. Although hypotheses lack specificity, the metabolism of certain carcinogenic compounds, such as the acetylation of arylamines from cooked meat, might be under genetic control. ${ }^{34}$ If calcium indeed stimulates DNA repair, ${ }^{35}$ this might be especially important for those who are genetically susceptible to DNAdamaging compounds. The fact that epidemiological studies have yielded weak associations and seemingly contradictory results might be explained by the simultaneous inclusion of colon cancers with distinct aetiologies as one single disease. Distinction of different types of colon cancer - those with and without ras mutations or those with a slow or a fast acetylator status - will help disentangle different aetiologies and might help explain the apparently inconsistent results of epidemiological studies, e.g. those addressing dietary calcium. Findings of 
epidemiological studies based on molecular tools might strengthen the scientific rationale for dietary advice relevant to colorectal cancer prevention.

In conclusion, our findings in four epidemiological studies show a neutral effect of dairy products, in particular fermented dairy products, and calcium in colorectal cancer aetiology. Furthermore, the Netherlands Case-Control Study supports a protective effect of vegetables, especially in women consuming a diet rich in red meat. These results are in line with the dietary recommendations put forward by the Dutch Nutrition Council and the Dutch Cancer Society.

\section{References}

1. Willett WC. Nutritional Epidemiology. New York: Oxford University Press, 1990.

2. van 't Veer P, Dekker JM, Lamers JWJ, et al. Consumption of fermented milk products and breast cancer: a case-control study in the Netherlands. Cancer Res 1989;49:4020-4023.

3. Bueno de Mesquita HB, Maisonneuve P, Runia S, Mocrman CJ. Intake of foods and nutrients and cancer of the exocrine pancreas: a population-based case-control study in the Netherlands. Int J Cancer 1990;48:540-549.

4. Annnymus. Wat eet Nederland 1987-1988? Rijswijk. Ministerie van Welzijn, Volksgezondheid en Cultuur en Ministcrie van Landbouw en Visscrij. 1988.

5. Iiricdenreich CM, Slimani N, Riboli E. Measurement of past diet: review of previous and proposed methods. Fpidemiol Rev 1992;14:177-196.

6. Potter JD, Slattery ML, Bostick RM, Gapstur SM. Colon cancer: a review of the cpidemiology. Epidemiol Rev 1993;15:499-545.

7. Garland CF, Garland FC, Gorham ED. Can colon cancer incidence and death rate be reduced with calcium and vitamin D? Am J Clin Nutr 1990;54:193S-201S.

8. Newmark HL, Wargovich MJ, Bruce WR. Colon cancer and dietary fat, phosphate, and calcium: a hypothesis. J Natl Cancer Inst 1984;72:1323-1325.

9. Kistemaker C, Aarnink EJM, Hulshof KFAM. Dutch National Food Consumption Survey 1987-1988. De consumptie van afzonderlijke produkten door Nederlandse bevolkingsgroepen. TNO-rapport V93.411, 1993.

10. Young TB and Wolf DA. Case-control study of proximal and distal colon cancer and diet in Wisconsin. Int J Cancer 1988;42:167-175.

11. Peters RK, Pike MC, Garabrant D, Mack TM. Diet and colon cancer in Los Angeles County, California. Cancer Causes Control 1992;3:457-473.

12. Tajima $\mathbf{K}$ and Tominaga $\mathbf{S}$. Dietary habits and gastro-intestinal cancers: a comparative casecontrol study of stomach and large intestinal cancers in Nogaya, Japan. Jpn J Cancer Res 1985;76:705-716.

13. Phillips RL and Snowdon DA. Dietary relationship with fatal colorectal cancer among Seventh-Day Adventists. J Natl Cancer Inst 1985;74:307-317.

14. Sanders ME. Dairy foods. Summary of conclusions from a consensus panel of experts on health attributes of lactic cultures: significance of fluid milk products containing cultures. $\mathbf{J}$ Dairy Sci 1993;76:1819-1828.

15. Goldin BR, Gorbach SL, Saxelin M, Barakat S, Gualtieri L, Salminen S. Survival of Lactobacillus species (Strain GG) in human gastrointestinal tract. Dig Dis Sci 1992:37:121128.

16. Pochart P, Marteau P, Bouhnik Y, Goderel I, Bourlioux P, Rambaud JC. Survival of bifidiobacteria ingested via fermented milk during their passage through the human small intestine: an in vivo study using intestinal perfusion. Am J Clin Nutr 1992:55:78-80.

17. Macquart-Moulin G, Riboli E, Cornée J, Kaaks R, Berthezène P. Colorectal polyps and diet: 
a case-control study in Marseilles. Int J Cancer 1987;40:179-188.

18. Benito E, Cabeza E, Moreno V, Obrador A, Bosch FX. Diet and colorectal adenomas: a case-control study in Majorca. Int J Cancer 1993;55:213-219.

19. Garland CF, Shekelle RB, Barrett-Conner E, Criqui MH, Rossof AH, Paul O. Dietary calcium and vitamin $\mathrm{D}$ and risk of colorectal cancer: a 19-year prospective study in men. Lancet $1985 ; 1: 307-309$.

20. Willett WC, Stampfer MJ, Colditz GA, Rosner BA, Speizer FE. Relation of meat, fat, and fiber intake to the risk of colon cancer in a prospective study among women. $\mathrm{N}$ Engl J Med 1990;323:1664-1672.

21. Bostick RM, Potter JD, Sellers TA, McKenzie DR, Kushi LH, Folsom AR. Relation of calcium, vitamin $\mathrm{D}$, and dairy food intake to incidence of colon cancer among older women. The Iowa Women's Health Study. Am J Epidemiol 1993;137:1302-1317.

22. Keamey J, Giovannucci E, Rimm EB, et al. Calcium, vitamin D and dairy foods and the occurrence of colon cancer in men (submitted for publication).

23. Bostick RM, Potter JD, Fosdick L, et al. Calcium and colorectal epithelial cell proliferation: a preliminary randomized, double-blinded, placebo-controlled clinical trial. J Natl Cancer Inst 1993;85:132-141.

24. Gregoire RC, Stern HS, Yeung KS, et al. Effect of calcium supplementation on mucosal cell proliferation in high risk patients for colon cancer. Gut 1989;30:376-382.

25. Stern HS, Gregoire RC, Kashtan H, Stadler J, Bruce RW. Long-term effects of dictary calcium on risk markers for colon cancer in patients with familial polyposis. Surgery 1990;108:528-533.

26. Kleibeuker JH, Welberg JWM, Mulder NH, et al. Epithelial cell proliferation in the sigmoid colon of patients with adenomatous polyps increases during oral calcium supplementation. Brit J Cancer 1993;67:500-503.

27. Barsoum GH, Thompsom H, Neoptolemos JP, Keighley MRB. Dietary calcium does not reduce experimental colorectal carcinogenesis after small bowel resection despite reducing cellular proliferation. Gut 1992;33:1515-1520.

28. Lipkin $M$ and Newmark $H$. Effect of added dietary calcium on colonic epithelial-cell proliferation in subjects of high risk for familial colonic cancer. N Engl J Med 1985;313:1381-1384.

29. Alder RJ, McKeown-Eyssen G, Bright-See E. Randomized trial on the effect of calcium supplementation on fecal risk factors for colorectal cancer. Am J Epidemiol 1993;138:804814.

30. Schatzkin A, Schiffman M, Lanza E. Research priorities in large bowel cancer prevention. Sem Oncology 1990;17:425-437.

31. Faivre J, Doyon F, Boutron MC for the EC.P colon group. The ECP calcium fiber polyp prevention study. Eur J Cancer Prev 1991:1(suppl2):83-89.

32. Paraskeva C. Colorectal cancer and dietary intervention. Lancet 1992;339:869-870.

33. Buset $M$, Lipkin $M$, Winawer $S$, Swaroop $S$, Friedman E. Inhibition of human colonic epithelial cell proliferation in vivo and in vitro by calcium. Cancer Res 1986:46:5426-5430.

34. Kadlubar FF, Butler MA, Kaderlik KR, Chou HS, Lang NP. Polymorphisms for aromatic amine metabolism in humans: relevance for human carcinogenesis. Environ Health Persp 1992;98:69-74.

35. Llor X, Jacoby RF, Teng BB, Davidson NO, Sitrin MD, Brasitus TA. K-ras mutations in 1,2-Dimethylhydrazine-induced colonic tumors: effects of supplemental dietary calcium and vitamin D deficicncy. Cancer Res 1991;51:4305-4309. 


$$
\text { . }
$$


Summary 


\section{Summary}

Colorectal cancer is one of the most prevalent cancers in westernized countries; in the Netherlands, about 7000 new cases are diagnosed each year. Since mortality rates are still relatively high and no major improvements in treatment strategies are expected in the near future, prevention of colorectal cancer is of major importance.

Chapter 2 provides an overview of the current concepts in the aetiology of colorectal cancer. In the past decades several stages in the multistep process of colorectal carcinogenesis have been identified, and it appeared that colorectal cancer arises as a result of the mutational activation of oncogenes coupled with the mutational inactivation of tumor suppressor genes. The vast majority of colorectal tumors are thought to arise in adenomatous polyps. The risk of developing an adenoma or carcinoma might depend on both genetic and environmental factors. Diet is considered to be one of the most plausible environmental factors, since the large bowel is in direct contact with the digested foods and their metabolites. A widely accepted hypothesis is that a westernized high-fat, low-fiber diet increases the risk for colorectal cancer. In terms of foods, an increased risk has mainly been attributed to the consumption of red meat and a decreased risk to the consumption of vegetables and fruits.

Besides a higher consumption of vegetables and fruits, a higher consumption of fermented dairy products, such as yogurt, buttermilk and cheese, might provide a relatively simple and feasible dietary modification for colorectal cancer prevention. Experimental studies suggest that a protective effect of fermented dairy products might be attributable to either the presence of lactic acid bacteria or their calcium content. Certain strains of lactobacilli might positively influence the colonic flora, stimulate the immune response or bind mutagens. Calcium might reduce the proliferative activity of the colon mucosa indirectly by diminishing the proliferative stimulus of secondary bile acids and free fatty acids in the colonic lumen or directly by inducing cell differentiation. As discussed in Chapter 2, few epidemiological studies conducted to date have addresised the consumption of fermented dairy products, while the epidemiological studies on calcium are not conclusive.

This thesis describes the results of four epidemiological studies investigating whether the consumption of fermented dairy products and the intake of calcium could provide feasible tools to prevent colorectal cancer. The studies represent different end-points and levels of exposure, different study designs and dietary methodologies and different populations (Chapters 3 through 8). 
Chapter 3 describes results of two of these four studies, The Nurses' Health Study (NHS; 98,464 women; 30-55 years at baseline), and The Health Professionals Follow-up Study (HPFS; 51,529 men; 40-75 years at baseline); both ongoing studies have been conducted at the Harvard School of Public Health in Boston, US. In these large prospective studies, the association between fermented dairy products, calcium and the occurrence of colorectal adenomatous polyps was investigated using a self-administered semi-quantitative food frequency questionnaire. Cases (331 men and 350 women) were patients with adenomatous polyps of the left colon or rectum diagnosed during four years (HPFS and NHS) or eight (NHS) years of follow-up; controls (9,159 men and 8,585 women) were persons with negative endoscopies. After adjustment for age, total energy, family history and saturated fat, fermented dairy product consumption was not related to the risk of adenomas (NHS: relative risk (RR) for highest vs. lowest cetgory of consumption $=0.8,95 \%$ confidence interval $(\mathrm{CI})=0.5-1.1$; HPFS: $\mathrm{RR}=1.1,95 \% \mathrm{Cl}=0.7-1.6)$. Adjustment for other potential confounding variables did not change the results importantly. Calcium intake from dietary sources and supplements was unrelated to adenoma risk in men (multivariate $\mathrm{RR}$ for highest vs. lowest quintile of intake $=1.1,95 \%$ $\mathrm{CI}=0.8-1.7)$ and women $(\mathrm{RR}=1.2,95 \% \mathrm{Cl}=0.8-1.7)$. No important differences were observed for dietary or supplemental calcium. Although no association with dietary vitamin D was found, vitamin D from supplements was slightly, but not significantly, inversely associated with risk among women only $(R R=0.7,95 \%$ $\mathrm{Cl}=0.4-1.1)$.

The hypothesis was further explored in two Dutch studies since in the Netherlands the consumption of fermented dairy products is integrated in the traditional food pattern and the variation in consumption is sufficiently large. A population-based case-control study was conducted in the eastern and central parts of the Netherlands (Chapters 4 through 7). Dietary patterns were assessed among 232 colon cancer cases and 259 controls by means of a structured dietary history questionnaire. As described in Chapter 4, cases were recruited by surgeons in 14 cooperating hospitals. The cancer registries of the central and eastern parts of the Netherlands were used as a check of completeness and provided additional clinical and pathological information. Controls, frequency-matched to the cases by age (5-year intervals), gender, region and urbanization grade, were recruited randomly by the general practitioners of the participating cases. After adjustment for potential confounding variables, the consumption of fermented milk (odds ratio (OR) for highest vs. lowest category of consumption $=1.1,95 \% \mathrm{CI}=0.6-1.8)$ and hard cheese $(\mathrm{OR}=1.2,95 \% \mathrm{CI}=0.7-2.1)$ were not significantly associated with risk of colon cancer (Chapter 5). Dietary calcium was positively associated with colon 
cancer risk (multivariate $\mathrm{OR}=1.8 ; 95 \% \mathrm{CI}=1.1-3.1$ ). This unexpected finding is discussed in Chapters 5 and 9. The observed associations differed between men and women: positive associations were observed in men, while in women nonsignificant associations were found. Sex differences in colon cancer risk were also observed for the consumption of fruits and red meat, for parity and age at the birth of the first child (Chapters 6 and 7).

In line with previous studies, the consumption of vegetables was significantly associated with reduced colon cancer risk $(\mathrm{OR}=0.4,95 \% \mathrm{CI}=0.2-0.7)$ in the Netherlands case-control study. The results suggest that this may be especially important for women consuming a diet high in red meat (Chapter 7).

Since prospective studies are less prone to biases related to the presence of disease or selection of subjects, the association between fermented dairy products, dietary calcium and colorectal cancer was additionally studied in The Netherlands Cohort Study on diet and cancer (Chapter 8). This prospective study started in 1986 when 120,852 Dutch men and women, aged 55-69, completed a food frequency questionnaire. The case-subcohort analysis was based on 3.3 years of follow-up and included 215 incident cases of colon cancer and 111 incident cases of rectal cancer, excluding cases diagnosed in the first year of follow-up. Colorectal cancer risk was not significantly related to the consumption of fermented milk $(\mathrm{RR}=0.9,95 \%$ $\mathrm{Cl}=0.6-1.3)$ and cheese $(\mathrm{RR}=0.9,95 \% \mathrm{Cl}=0.6-1.3)$.

Dietary calcium intake was not significantly associated with risk either $(R R=0.9$, $95 \% \mathrm{CI}=0.6-1.3)$. Only calcium from unfermented dairy products was inversely associated with rectal cancer risk $(R R=0.6,95 \% \mathrm{CI}=0.3-1.0$, trend $\mathrm{p}=0.03)$.

Chapter 9 summarizes the results and discusses the strengths and limitations of these four studies. Results are discussed in the context of the findings of previous epidemiological studies and experimental research. Overall, the results of the four studies described in this thesis do not support the hypothesized preventive potential of fermented dairy products and dietary calcium in colorectal carcinogenesis. These findings contrast with previous case-control studies addressing fermented milk (yogurt and buttermilk), and strengthen the null findings of 12 out of 21 epidemiological studies that addressed dietary calcium. The null findings of our studies are not likely to be explained by the end-points studied, the methods of exposure assessment, the variation in fermented dairy product consumption or calcium intake, the actual level of calcium intake, or confounding. However, these studies do not exclude the possibility that inverse associations might still be found for dairy products cultured with other bacterial strains. 
Further epidemiological studies on fermented dairy products, calcium and colorectal cancer should especially explore different sites within the colon, preferably including markers of genetic susceptibility. Epidemiological as well as experimental research should focus more explicitly on different end-points, sex differences and the effects of commercially available fermented dairy products in the aetiology of colorectal cancer.

Our findings of a neutral effect of dairy products and, as observed in the casecontrol study, a protective effect of vegetables especially in women consuming a high-meat diet (Chapter 7), are in line with the dietary recommendations put forward by the Dutch Nutrition Council and the Dutch Cancer Society. 
. 


\section{Samenvatting}




\section{Samenvatting}

Dikke darmkanker (colon- en rectumkanker) is één van de belangrijkste vormen van kanker in westerse landen; in Nederland worden ieder jaar ongeveer 7000 nieuwe gevallen gediagnostiseerd. Hoewel de vijf-jaars overleving stijgt bij vroege diagnostiek, wordt geen belangrijke vooruitgang op therapie-gebied verwacht in de nabije toekomst. Preventie van deze vorm van kanker blijft daarom van groot belang.

In hoofdstuk 2 wordt een overzicht gegeven van de huidige kennis over de oorzaken van dikke darmkanker. In de afgelopen 20 jaar zijn verschillende fasen in de vorming van darmtumoren geïdentificeerd en is gebleken dat darmkanker ontstaat door verschillende mutaties in oncogenen en tumorsuppressorgenen. De meeste darmtumoren ontstaan uit adenomateuze poliepen. Zowel genetische factoren als omgevingsfactoren kunnen het risico op het ontstaan van een darmpoliep of tumor beïnvloeden. Wat betreft omgevingsfactoren wordt voeding als één van de belangrijkste risicofactoren beschouwd, aangezien de darmwand in direct contact staat met voedselbestanddelen en metabolieten hiervan. Een algemeen geaccepteerde hypothese betreft een verhoging van het darmkankerrisico door een westers voedingspatroon dat gekenmerkt wordt door een hoge vet- en een lage vezelinneming. Wat voedingsmiddelen betreft lijkt vleesconsumptie het risico te verhogen, terwijl de consumptie van groente en fruit het risico zou kunnen verlagen. Naast een toename van de groente- en fruitconsumptie is verondersteld dat een toename van de consumptie van gefermenteerde zuivelprodukten, zoals yoghurt, karnemelk en kaas, eveneens een bijdrage zou kunnen leveren aan de preventie van dikke darmkanker. Experimentele studies suggereren dat een eventuele beschermende werking van gefermenteerde zuivelprodukten toegeschreven zou kunnen worden aan de Lactobacillus bacteriën die deze produkten bevatten of aan het relatief hoge calcium gehalte van zuivelprodukten in het algemeen. Bepaalde Lactobacillus stammen kunnen de normale bacterieflora in de dikke darm gunstig beïnvloeden, het immuunsysteem stimuleren en/of mutagene stoffen binden. Calcium zou de deling van darmwandcellen indirect kunnen beïnvloeden door toxische secundaire galzuren en vrije vetzuren te binden of direct door celdifferentiatie te induceren. Tot nu toe is slechts in een beperkt aantal epidemiologische studies de relatie tussen de consumptie van gefermenteerde zuivelprodukten en het ontstaan van darmkanker onderzocht. Meerdere studies zijn uitgevoerd naar de relatie met calciuminneming, maar de resultaten van deze studies lijken niet consistent te zijn. 
Dit proefschrift beschrijft en bediscussieert de resultaten van vier epidemiologische studies waarin is onderzocht of het gebruik van gefermenteerde zuivelprodukten en de inneming van calcium invers geassocieerd zijn met het ontstaan van dikke darmkanker. In deze studies zijn verschillende eindpunten van de ziekte bestudeerd (adenomateuze poliepen en tumoren) en zijn verschillende epidemiologische onderzoeksmethoden (retrospectief en prospectief) en verschillende methoden van voedselconsumptie onderzoek gebruikt (dietary history en schriftelijke voedselfrequentie vragenlijsten). Tevens zijn de studies uitgevoerd in verschillende populaties (Amerika, Nederland, mannen en vrouwen) van verschillende leeftijd en met een verschillend consumptiepatroon van gefermenteerde zuivel.

Hoofdstuk 3 beschrijft de resultaten van twee van deze studies: de Nurses' Health Study (NHS: 98.464 vrouwen, 30-55 jaar aan het begin van de studie) en de Health Professionals Follow-up Study (HPFS: 51.529 mannen, 40-75 jaar aan het begin). Deze prospectieve studies worden momenteel uitgevoerd aan de Harvard School of Public Health in Boston, Verenigde Staten. De associatie tussen de consumptie van gefermenteerde zuivelprodukten, de inneming van calcium en het voorkomen van adenomateuze darmpoliepen is bestudeerd gebruikmakend van een semi-quantitatieve schriftelijke voedselfrequentievragenlijst. Het voedingspatroon van patiënten (331 mannen en 350 vrouwen) met adenomateuze poliepen in het linker colon en het rectum gediagnostiseerd binnen vier (NHS en HPFS) of acht jaar (NHS) na het invullen van de vragenlijst, zijn vergeleken met het patroon van personen bij wie tijdens endoscopie géén adenomen werden waargenomen (9.159 mannen en 9.858 vrouwen). Na correctie voor leeftijd, totale energie-inneming, het voorkomen van dikke darmkanker in de familie, en de inneming van verzadigd vet, was de consumptie van gefermenteerde zuivelprodukten niet geassocieerd met het ontstaan van darmpoliepen (NHS: relatief risico hoogste versus laagste consumptiecategorie $(\mathrm{RR})=0,8 ; 95 \%$ betrouwbaarheidsinterval $($ btbhi) $=0,5-1,1) ; \mathrm{HPFS}: \mathrm{RR}=1,1 ; 95 \%$ btbhi $=0,7-1,6)$. Correctie voor andere mogelijk verstorende variabelen veranderde deze resultaten nauwelijks. De calciuminneming uit de voeding was evenmin geassocieerd met ontstaan van poliepen, zowel voor mannen (multivariate RR hoogste versus laagste quintiel van inneming $=1,1 ; 95 \%$ btbhi $=0,8-1,7$ ) als vrouwen $(\mathrm{RR}=1,2 ; 95 \%$ btbhi $=0,8-1,7)$. Er werden geen belangrijke verschillen in RRs gevonden voor calcium uit de voeding of uit supplementen. Hoewel geen associatie met vitamine $D$ uit de voeding werd gevonden, was vitamine $D$ uit supplementen, hoewel niet significant, invers geassocieerd met het ontstaan van poliepen bij vrouwen $(\mathrm{RR}=0,7 ; 95 \%$ btbhi $=0,4-1,1)$. 
Omdat de consumptie van gefermenteerde melk (yoghurt en kamemelk) geïntegreerd is in het traditionele Nederlandse voedingspatroon en de variatie in consumptie hoog genoeg lijkt, is de hypothese verder getest in twee Nederlandse studies: een patiënt-controle onderzoek en een prospectieve studie. In Midden en Oost Nederland is tussen 1990 en 1994 een patiënt-controle onderzoek naar darmkanker (colonkanker) uitgevoerd (Hoofdstukken 4 tot en met 7).

Voedingsgewoonten zijn nagegaan van 232 patiënten met colonkanker, die voldeden aan de insluitingscriteria, en 259 controlepersonen, gebruikmakend van een gestructureerde 'dietary history' vragenlijst (Hoofdstuk 4). Patiënten werden gerecruteerd door specialisten in 14 ziekenhuizen. De kankerregistraties van het Integrale Kankercentrum Midden Nederland en het Integrale Kankercentrum Oost werden gebruikt als compleetheidscheck en leverden additionele klinische en pathologische informatie (Hoofdstuk 4). Controles, die qua leeftijd (5-jaar intervallen), geslacht, regio en urbanisatiegraad overeen kwamen met de patiënten, werden aselect gerecruteerd via de huisarts van de deelnemende patiënt (Hoofdstuk 4). Na correctie voor eventuele verstorende variabelen was de consumptie van gefermenteerde melkprodukten (odds ratio hoogste versus laagste consumptie $(\mathrm{OR})=1,1 ; 95 \%$ btbhi $=0,6-1,8)$ en van kaas $(\mathrm{OR}=1,2 ; 95 \%$ btbhi $=0,7-2,1)$ niet significant geassocieerd met het risico op darmkanker. (Hoofdstuk 5). Calcium uit de voeding was positief geassocieerd met het darmkanker risico (multivariate $\mathrm{OR}=1,8 ; 95 \%$ btbhi $=1,1-3,1$ ). Deze onverwachte bevinding wordt besproken in hoofdstukken 5 en 9 . De associaties met darmkanker verschilden tussen mannen en vrouwen: positieve associaties werden gevonden voor mannen, terwijl voor vrouwen niet-significante inverse associaties werden gevonden (Hoofdstuk 5). In dit patiënt-controle onderzoek werden eveneens geslacht-gebonden verschillen in darmkanker-risico gevonden voor de consumptie van fruit en vlees, voor het aantal kinderen dat men had en de leeftijd waarop men voor het eerst moeder of vader werd (Hoofdstukken 6 en 7).

In overeenstemming met de resultaten van eerder epidemiologisch onderzoek, werd in dit onderzoek een inverse associatie gevonden tussen de consumptie van groente en het risico op darmkanker. De resultaten suggereren dat dit met name belangrijk zou kunnen zijn voor vrouwen met een relatief hoge vleesconsumptie (Hoofdstuk 7).

De resultaten van prospectieve epidemiologische studies worden waarschijnlijk minder dan patiënt-controle studies vertekend door de aanwezigheid van ziekte tijdens het interview of door mogelijke differentiële selectie van patiënten en controlepersonen. Daarom is de relatie tussen de consumptie van gefermenteerde zuivelprodukten, de inneming van calcium en het ontstaan van colorectaal kanker 
eveneens bestudeerd in de Nederlandse Cohort Studie naar Voeding en Kanker (Hoofdstuk 8). Deze prospectieve studie is gestart in 1986 toen 120.852 mannen en vrouwen, in de leeftijd van 55 tot en met 69 jaar, een voedselfrequentie vragenlijst invulden. In de statistische analyse ('case-subcohort') werden de eerste 3,3 jaar van follow-up betrokken. Na uitsluiting van patiënten die gediagnostiseerd werden in het eerste jaar na de start van het onderzoek, werd de analyse uitgevoerd met 215 colonkankerpatiënten en 111 rectumkankerpatiënten. Colorectaal kanker bleek niet significant geassocieerd te zijn met de consumptie van gefermenteerde melk (multivariate RR hoogste versus laagste consumptie categorie $=0,9 ; 95 \%$ btbhi $=0,1-1,3)$ en kaas $(R R=0,9 ; 95 \%$ btbhi $=0,6-1,3)$. Calcium uit de voeding was eveneens niet geassocieerd met het risico ( $R \mathrm{R}=0,9 ; 95 \%$ btbhi $=0,6-1,3$ ). Alleen calcium afkomstig uit niet-gefermenteerde zuivelprodukten was invers geassocieerd met het risico op rectumkanker $(R R=0,6 ; 95 \%$ btbhi $=0,3-1,0$; trend $\mathrm{p}=0,03)$.

Hoofdstuk 9 vat de resultaten van de vier studies samen en bediscussieert de sterke en zwakke aspecten van deze studies. De resultaten worden bediscussieerd in de context van de bevindingen van eerder epidemiologisch en experimenteel onderzoek.

De resultaten van de in dit proefschrift opgenomen studies ondersteunen niet de hypothese dat gefermenteerde zuivelprodukten en calcium uit de voeding een belangrijke preventieve rol zouden kunnen spelen in de etiologie van dikke darmkanker. Deze resultaten zijn niet in overeenstemming met eerder patiëntcontrole onderzoek naar gefermenteerde melk, maar ondersteunen de resultaten van 12 van de 21 epidemiologische studies waarin eveneens geen belangrijke associatie tussen calciuminneming en colorectaal kanker werd gevonden. Het feit dat in onze vier studies geen associatie met gefermenteerde zuivel of calcium uit de voeding werd gevonden kan waarschijnlijk niet verklaard worden door de gebruikte methoden om voedselconsumptie te schatten, de variatie in gefermenteerde zuivel consumptie en calciuminneming, de totale calciuminneming, of aan confounding. Echter, deze studies sluiten een beschermende werking van minder algemeen gebruikte zuivelprodukten, gefermenteerd met andere bacteriestammen, niet uit.

In volgend epidemiologisch onderzoek naar gefermenteerde zuivelprodukten, calcium en colorectaal kanker zouden de verschillende sublocalisaties in het colon nader moeten worden bestudeerd. Hierbij zouden bij voorkeur merkers van genetische gevoeligheid moeten worden betrokken. Epidemiologisch, zowel als experimenteel onderzoek zou zich meer moeten richten op verschillende ziekteeindpunten en geslachtsverschillen in de etiologie van dikke darmkanker. 
Het neutrale effect van zuivelprodukten en, zoals gevonden in het patiënt-controle onderzoek. het beschermend effect van groente (speciaal voor vrouwen met een rclatief hoge vleesconsumptie) ondersteunen de voedingsaanbevelingen van de Nederlandse Kankerbestrijding en de richtlijnen goede voeding van de Nederlandse Voedingsraad. 


\section{Dankwoord/Acknowledgements}

"Kun je je werkelijk vier jaar bezighouden met de vraag of gefermenteerde zuivelprodukten beschermen tegen darmkanker?" was én van de vele vragen die ik Pieter van 't Veer heb gesteld voordat dit project begon. Gelukkig zei hij "Ja!".

Pieter, zonder jou was er geen begin en geen eind aan dit project gekomen. Hoewel $\mathrm{ik}$ je statistische omzwervingen niet altijd kan volgen, word ik vaak door jouw enthousiasme voor de wetenschap meegesleept. Ik had mij geen (o)-promotor kunnen wensen die meer betrokken en motiverender zou zijn gewec'st dan jij. Goed dat we blijven samenwerken!

Hans Berkel en Frans Kok hebben destijds het initiatief genomen om mij voor dit project uit te nodigen. Hans was hoofd kankerregistratie van het Integraal Kankercentrum Midden Nederland, terwijl ik daar werkte als registratiemedewerker. Hans, jammer dat je er, door je vertrek naar Canada, niet meer bij betrokken kon zijn. Frans, ondanks jou vertrek bij TNO, terwijl ik daar net kwam kijken, is je betrokkenheid niet verminderd. Jouw idee om naar Boston te gaan is tevens cen zeer belangrijk aspect van dit proefschrift.

Ruud Hermus wil ik graag bedanken voor zijn rol als eerste promotor en voor de mogelijkheid om dit project binnen TNO-Voeding in Zeist uit te voeren.

Gert Jan Hiddink, jouw aanwezigheid in mijn begeleidingscommissie heb ik bijzonder op prijs gesteld. Jouw weloverwogen adviezen en integere aanpak hebben een belangrijke rol gespeeld bij de uitvoer van dit onderzoek en het tot stand komen van dit proefschrift.

Wiebe Visser dank ik graag voor het gestelde vertrouwen in de opzet en de afronding van het patiënt-controle onderzoek (ondanks het rode jasje).

Het patiënt-controle onderzoek in dit proefschrift is speciaal voor dit doel opgezet en uitgevoerd en heeft vele mensen zweetdruppeltjes opgeleverd. Dank allereerst aan duizendpoot Hanny Leezer! Van jou heb ik, naast andere levenswijsheden, geleerd hoe je de praktische uitvoer van zo'n onderzoek zo gecoördineerd en gestructureerd mogelijk kunt aanpakken. Ongelooflijk hoe je orde weet te scheppen in (mijn) chaos. Je was zo betrokken bij dit project dat het zelfs mee moest op vakantie... Dank zij jou ziet ook dit boekje er fantastisch uit. Ik zal je missen!

Geen onderzoek zonder deelnemers: graag wil ik de deelnemers aan het patiëntcontrole onderzoek bedanken voor hun bereidwilligheid om aan dit zeer intensieve, vermoeiende interview mee te doen.

Verder mijn dank aan de specialisten en andere medewerkers in de regionale ziekenhuizen die, ondanks hun drukke hezigheden, tijd konden vinden voor het 
uitnodigen van deelnemers. De 14 deelnemende ziekenhuizen staan elders in dit proefschrift vermeld.

Wanneer de kankerregistraties van het Integrale Kankercentrum Midden Nederland en het Integrale Kankercentrum Oost niet bij dit onderzoek betrokken waren geweest, had de patiëntenwerving wel héél lang geduurd. Charles Gimbrère, Irma van Beuningen, Ingrid Wildschut, Bart Kiemeney, Mirjam Scholte, Linda Traa, Leo Schouten, Marjorie de Kok en alle andere medewerkers van de registraties: jullie vormen ongetwijfeld de belangrijkste onderbouwing voor mijn stelling.

Het protocol voor de controlewerving is tot stand gekomen met de hulp van het Nederlands Huisartsen Genootschap. Joost Zaat wil ik hierbij speciaal bedanken voor het meedenken en de belangrijke adviezen. De huisartsen, arts-assistenten en medewerkers van de gemeenten die een zeer belangrijke bijdrage aan de controlewerving hebben geleverd, wil ik graag bedanken voor hun bereidheid aan dit onderzoek mee te doen.

Susanne Westenbrink en Petra van Aken-Schneijder, bedankt voor het aanpassen van de vragenlijst, het opstellen van het draaiboek, codeerplan en het invoerprogramma van de gegevens. Petra, samen met Marie-Agnes van Erp-Baart heb jij tevens zorggedragen voor het trainen van de interviewers. Henny Brants bedankt voor alle vragen die ik je altijd weer ergens tussendoor mocht stellen (en voor het meetrekken naar 'de badminton'). Marco Bouman bedankt voor het ingenieuze verwerkingsprogramma van de voedingsvragenlijsten. Jan Blom en Cor Roodzant, dank jullie wel voor het copiëren van de verschrikkelijk dikke vragenlijsten.

De uitvoer van dit onderzoek heeft de interviewers veel reistijd, vele uren buiten de normale tijden en vele dikke boeken met eindeloos codeerwerk opgeleverd. Susan van der Wiel, Simone Peters, Muriel Langedijk, Sanne Hulshoff, Petra van AkenSchneijder, Regine de Gier en Maryse Niekerk bedankt voor jullie belangrijke inzet! En zo'n interview levert vếl gegevens op die allemaal moeten worden ingevoerd. Willy van Dijk, ik ben blij dat jij hierbij zoveel werk hebt kunnen verzetten en niet scheel bent geworden van al die getalletjes op één lijntje te krijgen.

Stagiaires van de Landbouwuniversiteit Wageningen hebben een belangrijk aandeel gehad in de gegevensanalyse van het patiënt-controle onderzoek. Dorette Verhoeven, Lisette Sloots, Arianne Morée-Bijl, Caroline Kok, Irene Lobbezoo en Kristelle Nusteling: dank jullie wel!

Arthur van Aken bedankt voor de mooie plaatjes die dit proefschrift wat leesbaarder maken.

Aan de opzet en uitvoer van de cohort studies beschreven in dit proefschrift heb ik niets bijgedragen. Graag wil ik iedereen bedanken die dit wel veel tijd en energie heeft gekost. 
Sandra Bausch en Piet van den Brandt bedankt voor de samenwerking bij de analyses in de Nederlandse Cohort Studie naar voeding en kanker. Sandra, bij jou kon ik mijn colonkankerei kwijt; het is goed om te weten dat jij mijn geslacht- en 'site'-specifieke frustraties deelt.

The other two cohort studies described in this thesis are the hard work of many people at the Departments of Nutrition and Epidemiology at the Harvard School of Public Health in Boston. I would like to thank Walter Willett for giving me the opportunity to analyse the data of these studies, for his support and advise. Ed Giovannucci shared my 'passion' for colorectal polyps. Thanks Ed, for your great help, for our endless discussions and for the running experience. Furthermore I would like to thank Meir Stampfer for his valuable comments on the manuscript and Dimitrios Trichopoulos for his inspiring lectures. Boston and Harvard were a great experience, which is mostly due to the people who surrounded me: Jane, Tom, Joe, Mary, Walid, Diane, I-Min, Sarah, Al, Myra, Francine, Eric, Alberto, Cock, Helen and all others, thanks for everything!

A special thanks to John Potter for giving me the idea that colon cancer is the most interesting topic to study.

Dirk van der Heij, jouw rode pen heeft ervoor gezorgd dat dit proefschrift ook voor engels sprekenden leesbaar is. Niek van Breederode, jou mocht ik altijd bellen: van stekkertjes tot modem password. Dank voor het geduld! Louis Willemsens, jou interesse in het onderzoek heb ik erg op prijs gesteld. Bedankt voor het heveiligen van de adressenbestanden.

Alwine en Jacqueline, het tegelijkertijd in de stress 'zitten' kon gelukkig soms verkoelend werken. Mooi dat dit voor ons alle drie nu afgelopen is! Mede AIO/OIO's Erica, Trinette, Wendy, Ellen, Esther en Lucy, leuk en relativerend waren de etentjes. Lucy, jij speciaal bedankt voor het feit dat je het uit hebt kunnen houden om in het laatste jaar van dit onderzoek een kamer met mij te delen. Geert, dank voor het plezier en toch ook voor de soms verhitte discussies. TNO collega's die ik nog niet genoemd heb, maar niet vergeten ben, bedankt voor de gezellige tijd!

Greetje, Martine, Michèl, 'de dames', andere vrienden en de familie Jumelet, jullie hebben het steeds op kunnen brengen om te informeren naar mijn werk en ook nog naar mijn antwoord geluisterd. Ik zal proberen om het nu weer over iets anders te hebben. 
Pa en ma, jullie hebben altijd enorm meegeleefd: van salaris, via stellingen naar promotiepak. Zelfs als het voor jullie niet altijd even leuk was hebben jullie me gesteund, zoals bijvoorbeeld in het altijd zo nodig naar het buitenland moeten... Zulke vrienden vind je nergens. Dank jullie wel voor alles!

Nooit gedacht dat iemand deze laatste, en oh zo belangrijke, alinea in zou nemen: Hans, het is niet te geloven, hoe een pinguïn een schildpad zo nodig kan hebben. Wat hebben we een stappen genomen in wel héél korte tijd en wat zullen we er gelukkig nog vele nemen. Let's hit the road! 


\section{Acknowledgement Hospitals}

The following surgeons and colleagues of regional hospitals have contributed significantly to the recruitment of colon cancer patients in the Netherlands case-control study (in order of cases interviewed).

Mrs.Dr. R.F. van der Sluis (Academisch Ziekenhuis Nijmegen St. Radboud, Nijmegen)

Dr. J.P. Vente (Hofpoort Ziekenhuis, Woerden)

Dr. W.J.C. Geurts (Ziekenhuis Oudenrijn, Utrecht)

Dr. W.J. van der Ven (Lorentz Ziekenhuis, Zeist)

Dr. K.H. Ong (Ziekenhuis Rivierenland, Tiel)

Dr. C.I. Perre (Diakonesenhuis, Utrecht)

Dr. K.A. Koop (Molendael Ziekenhuis, Baarn)

Dr. Sj.H.M. Vrind (Medisch Centrum Berg en Bosch, Bilthoven)

Dr. F. van Himbeeck (Ziekenhuis Canisius-Wilhelmina, Nijmegen)

Dr. E.D.M. Bruggink (Ziekenhuis Canisius-Wilhelmina, Nijmegen)

Mrs. A. de Kruijf (Academisch Ziekenhuis Utrecht, Utrecht)

Dr. E.B.M. Theunissen (Ziekenhuis Overvecht, Utrecht)

Dr. R.F. Schmitz (Stichting Sint Antonius Ziekenhuis, Nieuwegein)

Mrs. R. Huurdeman (Ziekenhuis Eemlanden, voorheen 'De Lichtenberg', Amersfoort) Dr. W.F. Kniestedt (Ziekenhuis Eemlanden, voorheen 'De Lichtenberg', Amersfoort) Dr. I.P.O.C.M. van Meerwijk (Ziekenhuis Eemlanden, voorheen 'Elisabeth', Amersfoort) 


\section{About the author}

Ellen Kampman was born in Utrecht, the Netherlands, on April 29th 1962. After secondary school (Athenaeum B) at 'Schoonoord' in Zeist, she studied Human Nutrition at the Department of Nutrition, Agricultural University, Wageningen. The M.Sc. program focused primarily on epidemiology, human nutrition and toxicology. She graduated with honours in June 1988, after a five months training period at the Athens School of Public Health in Athens, Greece.

Subsequently, she was appointed as part-time research associate at the Department of Human Nutrition, Agricultural University in Wageningen and as part-time tumor registrar at the Comprehensive Cancer Centre Middle Netherlands in Utrecht.

In November 1989, she started the research described in this thesis at the Department of Nutrition, TNO Nutrition and Food Research in Zeist. As part of this research, she worked at the Departments of Nutrition and Epidemiology at the Harvard School of Public Health, Boston, US, in the academic year 1991 for a period of six months. During her stay in Boston, she attended the New England Epidemiology Summer Program and courses in nutritional epidemiology and statistics at the Harvard School of Public Health.

She attended a course on 'molecular biology for cancer epidemiologists' organized by the Internal Agency for Research on Cancer in Lyon, France, was further trained in molecular biology during her stay at Harvard and was recently rewarded with a two-year epidemiologic fellowship from the Netherlands Cancer Foundation to specialize in molecular epidemiology. Experience will be gained with the implementation of molecular tools in epidemiologic studies at the Cancer Prevention Program of the Fred Hutchinson Cancer Research Center, Seattle, US. The Department of Epidemiology and Public Health at the Agricultural University of Wageningen will be the home address for the fellowship in the Netherlands. 


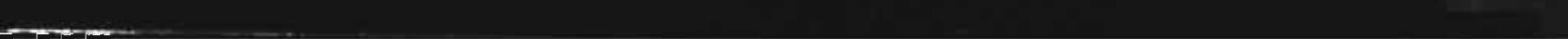

